Universidade de São Paulo

Instituto de Astronomia, Geofísica e Ciências Atmosféricas

Departamento de Geofísica

Oksana Shevchenko Bokhonok

\title{
Estudo comparativo da resposta das ondas convertidas na investigação rasa: aquisição, processamento e interpretação
}

Versão Corrigida. O original encontra-se disponível na Unidade.

São Paulo

2018 

Oksana Shevchenko Bokhonok

\section{Estudo comparativo da resposta das ondas convertidas na investigação rasa: aquisição, processamento e interpretação}

Dissertação apresentada ao Departamento Geofísica do Instituto de Astronomia, Geofísica e Ciências Atmosféricas da Universidade de São Paulo como requisito parcial para obtenção do título de Mestre.

Área de Concentração: Geofísica

Orientador: Prof. Dr. Renato Luiz Prado

São Paulo

2018 

Nome: SHEVCHENKO, Oksana

Título: Estudo comparativo da resposta das ondas convertidas na investigação rasa: aquisição, processamento e interpretação

Dissertação apresentada ao Departamento Geofísica do Instituto de Astronomia, Geofísica e Ciências Atmosféricas da Universidade de São Paulo como requisito parcial para obtenção do título de Mestre.

Aprovado em:

Banca Examinadora

Prof. Dr.

Instituição:

Julgamento:

Prof. Dr.

Instituição:

Julgamento:

Prof. Dr.

Instituição:

Julgamento: 



\section{AGRADECIMENTOS}

Ao meu esposo, com amor, admiração e gratidão por sua compreensão, carinho, presença e incansável apoio ao longo do período de elaboração deste trabalho.

À minha família, por estarem sempre presentes e me fornecerem o suporte necessário, amor e carinho.

Ao Dr. Renato Prado, pela confiança e pelo zelo profissional na minha formação de mestre.

Aos professores do mestrado, pelos importantes ensinamentos transmitidos.

Ao Marcelo e ao Hernande pela ajuda na aquisição dos dados para o projeto.

Aos funcionários de Instituto de Astronomia, Geofísica e Ciências Atmosféricas da USP, que fazem com que tudo funcione da melhor maneira possível.

Ao Instituto de Astronomia, Geofísica e Ciências Atmosféricas da USP, pela oportunidade de realização do curso de mestrado.

Ao CNPq e à FAPESP, pela concessão da bolsa de mestrado e pelo apoio financeiro para a realização desta pesquisa.

A todos que diretamente ou indiretamente participaram e contribuíram com minha formação, o meu sincero muito obrigado! 

"Algo só é impossível até que alguém duvide e acabe provando o contrário."

Albert Einstein 



\title{
RESUMO
}

Visando estudo do método de sísmica multicomponente (3C) na investigação rasa, foram adquiridos dados em duas áreas urbanas da cidade de São Paulo, Brasil, com características geológicas diferentes: Campus da Universidade de São Paulo (USP), situado na zona oeste do município e área da estrutura de Colônia, situada na região de Parelheiros, na zona periférica do município. Na aquisição foram empregados geofones de 3 componentes com frequência natural de $10 \mathrm{~Hz}$ e, como fontes sísmicas, o compactador e o impacto de uma marreta. Para realizar o processamento dos dados foi utilizado o pacote Seismic Unix (CWP/SU). Foi observada uma marcada diferença nas respostas dos subsolos entre os dois sítios. Nos dados adquiridos no Campus da USP foram observadas tanto as ondas PP como as ondas convertidas (PSv), no entanto, nos dados obtidos em área de Colônia, não foi possível visualizar as ondas convertidas. A partir das secções da onda PP e da onda PS foi estimada a razão Vp/Vs assim como o coeficiente de Poisson para a área da USP.

\begin{abstract}
In order to study the multicomponent seismic method (3C) to shallow investigation, two data sets were acquired in urban areas of São Paulo city, Brazil, with different geological characteristics. The area of the Campus of São Paulo University (USP) is located in the western part of the city and the area of the structure of Colônia is located in the region of Parelheiros, a peripheral zone of São Paulo. For the data acquisition, it were employed 3C-geophones of 10 $\mathrm{Hz}$ and, as seismic sources, hand-operated surface compactor and sledge hammer. For processing were used the Seismic Unix package (CWP / SU). It was observed a marked difference in the subsoil responses between the two sites. In the data acquired in the Campus of USP, both PP waves and converted waves (PSv) was observed; however, in the data obtained in the Colônia area, it was not possible to visualize the converted waves. For the USP area, the $\mathrm{Vp} / \mathrm{Vs}$ ratio and Poisson ratio were estimated.
\end{abstract}





\section{LISTA DE FIGURAS}

Figura 2.1.1- Mapa de estado de São Paulo. Os pontos indicam a localização das áreas de estudos

Figura 2.1.2 - a) Aspecto morfológico da cratera de Colônia. b) Fotografia do interior da Cratera de Colônia.

Figura 2.1.3 - a) Área de estudo no Campus da Universidade de São Paulo (USP); b) Fotografia da área de estudo. .5

Figura 2.2.1 - Mapa geológico simplificado da estrutura de Colônia. 6

Figura 2.2.2 - Perfil descritivo do pacote sedimentar obtido de uma sondagem realizada para exploração de água subterrânea na Região de Colônia.

Figura 2.2.3 - Mapa de localização da área estudada dos poços para pesquisas geofísicas na área de Campus da USP.

Figura 2.2.4 - Correlação entre os perfis litológicos dos poços na área de Campus da USP.........9

Figura 3.1 - Decomposição da movimentação de partículas na passagem de uma onda em um meio homogêneo e isótropo.

Figura 3.2 - O modelo convolutivo de subsolo.

Figura 3.3 - Reflexões e refrações geradas a partir de uma onda P incidente em una interface entre dois meios com diferentes propriedades físicas.

Figura 3.4 - Raios sísmicos das ondas PP e PSv. .14

Figura 3.5 - Zona de Fresnel. .15

Figura 4.1 - Fontes sísmicas

Figura 4.2 - a) Princípio básico de funcionamento de sensor de velocidade; b) Sensor eletromagnético; c) Geofone 3C: sensores para registro das componentes vertical, radial e transversal; d) Geofone $3 \mathrm{C}$ da Geometrics.

Figura 4.3 - Componentes de Sistema microeletromecanico (MEMS): a) sensores de aceleração; b) Acelerômetro triaxial de Sercel.

Figura 4.4 - Acelerômetro ótico. .20

Figura 4.5 - Comparação entre as respostas de a) ganho e b) fase de acelerômetro e geofone de $10 \mathrm{~Hz}$ da Sercel.

Figura 4.6 - Sismógrafo Geode-Geometrics de 24 canais com conversor A/D de 24 Bits. 

Figura 5. 1 - Caminho do raio P-S esquemático, onde se observa o deslocamento de ACP para o receptor

Figura 6.1- Fluxograma geral de processamento dos dados sísmicos 2D.

Figura 6.2.9.1 - A onda que propaga-se em angulo $\alpha$ com a horizontal ao longo de arranjo de detectores com a velocidade aparente $V_{a}=V / \sin \alpha$

Figura 6.2.9.2 - Distribuição de sinal e ruído em um gráfico no domínio f-k

Figura 6.2.15.1 - Empilhamento dos traços de um conjunto CMP: a) conjunto CMP sem correção NMO; b) conjunto subcorrigido c) conjunto corrigido d) conjunto sobrecorrigido.

Figura 6.2.16.1 - Imagem da interface na posição espacial verdadeira.

Figura 6.2.16.2 - Tipos de migração dependendo da complexidade estrutural e variação de velocidade do subsolo.

Figura 6.3.4.1 - Ilustração de raios das ondas PS, onde CP são os pontos de conversão. .35

Figura 7.1.1 - a) Configuração dos cabos na aquisição para análise de ruído; b) disposição e offsets dos tiros realizados

Figura 7.1.2 - Sismogramas do teste de ruído com o compactador, área de estudo Colônia: a) componente vertical; b) componente radial e c) componente transversal.

Figura 7.1.3 - Sismogramas do teste de ruído com a marreta, área de estudo Colônia: a) componente vertical; b) componente radial e c) componente transversal.

Figura 7.1.4 - Sismograma de componente vertical do teste de ruído com o compactador (0 -0.4 segundos). Área de estudo: Colônia.

Figura 7.1.5 - Sismograma de componente vertical do teste de ruído com a marreta (0 -0.4 segundos). Área de estudo: Colônia.

Figura 7.1.6 - Sismogramas do teste de ruído com o compactador, área de estudo Campus da USP: a) componente vertical; b) componente radial e c) componente transversal.

Figura 7.1.7 - Sismogramas do teste de ruído com a marreta, área de estudo Campus da USP:

a) componente vertical; b) componente radial e c) componente transversal.

Figura 7.1.8 - Sismogramas de teste de ruído concatenados. Do lado esquerdo se encontra a seção adquirida com a marreta e à direita seção adquirida com o compactador: a) Colônia; b) Campus da USP.

Figura 7.2.1 - A linha sísmica 2D adquirida na área de Colônia. .44 

Figura 7.2.2 -Disposição dos cabos na aquisição da línea na área de Cratera de Colônia

Figura 7.2.3 - Área de Colônia: diferentes seções da linha sísmica adquirida na área com diferentes características de superfície.

Figura 7.3.1 - A linha sísmica 2D adquirida na área do Campus da USP. .46

Figura 7.3.2 - Disposição dos cabos na aquisição da linha na área do Campus da USP.

Figura 8.1.1 - Área de estudo: Colônia. Geometria de aquisição. A posição das fontes e receptores.

Figura 8.1.2 - Área de estudo: Colônia. Geometria de aquisição. A posição das fontes e pontos meios comuns.

Figura 8.1.3 - Área de estudo: Colônia. Geometria de aquisição. A posição das fontes e pontos assintóticos de conversão comuns (ACCP) com $\mathrm{Vp} / \mathrm{Vs}=3$.....

Figura 8.1.4 - Área de estudo: Colônia . A multiciplidade de traços a) para CDP da componente vertical; b) para ACCP das componentes horizontais $(\mathrm{Vp} / \mathrm{Vs}=3)$...

Figura 8.2.1 - Área de estudo: Colônia. Conjuntos de receptor comum. Componente vertical com traços ruidosos zerados.

Figura 8.3.1 - Área de estudo: Colônia. Conjuntos de tiro das componentes a) vertical; b) horizontal radial; c) horizontal transversal e seus respectivos espectros de amplitude d), e) e f).......

Figura 8.3.2 - Área de estudo: Colônia. Conjuntos de tiro das componentes a) vertical; b) horizontal radial; c) horizontal transversal e seus respectivos espectros de amplitude d), e) e f).

Figura 8.3.3 - Área de estudo: Colônia. Conjuntos de tiro das componentes a) vertical; b) horizontal radial; c) horizontal transversal e seus respectivos espectros de amplitude d), e) e f)......

Figura 8.3.4 - Área de estudo: Colônia. Espectros de amplitude das componentes verticais dos tiros FLDR 108 (a), FLDR 156 (b) e FLDR 204 (c) na faixa de frequências 0-160 Hz.

Figura 8.3.5 - Área de estudo: Colônia. Sismogramas das componentes verticais correspondentes aos conjuntos de tiros FLDR 122-123-124125. .56

Figura 8.4.1 - Área de estudo: Colônia. Seção de dados empilhados sem filtrar. .57

Figura 8.4.2 - Área de estudo: Colônia. Seção de dados empilhados com PB aplicado ao dado sem ganho. 

Figura 8.4.3 - Área de estudo: Colônia. Imagem da diferença entre seções empilhadas dos dados sem filtrar e dados filtrados com PB mas sem aplicação de ganho

Figura 8.4.4 - Área de estudo: Colônia. Seção de dados empilhados com PB aplicado ao dado com ganho (PBAL).

Figura 8.4.5 - Área de estudo: Colônia. Imagem da diferença entre as seções empilhadas dos dados sem filtrar e dados filtrados com PB e com ganho de equalização (PBAL).

Figura 8.4.6 - Área de estudo: Colônia. Componente horizontal radial. Seção empilhada sobre o receptor comum com PB aplicado ao dado com ganho. .59

Figura 8.4.7 - Área de estudo: Colônia. Componente horizontal radial. Seção empilhada no ACCP (Vp/Vs=3) com PB aplicado ao dado com ganho...

Figura 8.5.1 - Área de estudo: Colônia. Espectros f-k de sismogramas de tiro das componentes a) vertical; b) horizontal radial e c) horizontal transversal...

Figura 8.5.2 - Área de estudo: Colônia. O espectro do sinal no domínio f-k da componente horizontal radial a) conjunto de receptor comum; b) espectro correspondente no domínio f-k

Figura 8.5.3 - Área de estudo: Colônia. O espectro do sinal no domínio f-k da componente horizontal radial a) conjunto ACCP; b) espectro correspondente no domínio f-k...63

Figura 8.5.4 - Área de estudo: Colônia. Seção empilhada de dados com filtro FK aplicado ao dado sem ganho. Parâmetros do filtro aplicado: inclinações=-0.004,$0.001,0.001,0.004$.

Figura 8.5.5 - Área de estudo: Colônia. Imagem da diferença das seções empilhadas dos dados sem filtro FK e com filtro FK aplicado ao dado sem ganho. Parâmetros do filtro aplicado: inclinações $=-0.004,-0.001,0.001,0.004$ bias $=0.0025$.

Figura 8.5.6 - Área de estudo: Colônia. Seção empilhada dos conjuntos CMP com filtro FK aplicado ao dado com ganho (PBAL). Parâmetros do filtro aplicado: inclinações=$0.004,-0.001,0.001,0.004$, bias $=0.0025$.

Figura 8.5.7 - Área de estudo: Colônia. Imagem da diferença das seções empilhadas dos dados sem filtro FK e com filtro aplicado ao dado com ganho (PBAL). Parâmetros do filtro aplicado: inclinações $=-0.004,-0.001,0.001,0.004$, bias $=0.0025$.

Figura 8.5.8 - Área de estudo: Colônia. Seção empilhada da componente radial a partir de conjuntos de receptores com filtro $\mathrm{f}-\mathrm{k}$ aplicado ao dado com ganho (AGC com janela temporal de $0.5 \mathrm{~s}$ ). Parâmetros de filtro aplicado: inclinações $=-0.005$,$0.003,0.003,0.005$, bias $=0.0025$.

Figura 8.5.9 - Área de estudo: Colônia. Seção empilhada da componente radial a partir de conjuntos ACCP com filtro f-k aplicado ao dado com ganho. Parâmetros de filtro aplicado: inclinações $=-0.005,-0.003,0.003,0.005$, bias $=0.0025$. 

Figura 8.6.1 - Área de estudo: Colônia. Autocorrelaçao de traços a) tiros selecionados dos conjuntos correspondentes FLDR 103-123, b) tiros selecionados dos conjuntos correspondentes aos FLDR 124-222.. .66

Figura 8.6.2 - Área de estudo: Colônia. Seção empilhada em coordenadas CMP correspondentes aos conjuntos de tiro FLDR103-123 (com deconvolução) e FLDR 124-222 (sem deconvolução)......

Figura 8.6.3 - Área de estudo: Colônia. Seção empilhada em coordenadas CMP. Dados deconvolvidos com parâmetros diferentes para as séries de conjuntos de tiros FLDR 103-123 e FLDR 124-222.

Figura 8.7.1 - Área de estudo: Colônia. Gráfico da função semblance do conjunto CMP 50 antes da deconvolução (esquerda) e após a aplicação da deconvolução (direita). .68

Figura 8.8.1 - Área de estudo: Colônia. Seção empilhada com a aplicação do filtro de Harlan nos dados deconvolvidos (cdp correspondentes aos conjuntos de tiros fldr103-fldr 123).

Figura 8.8.2 - Área de estudo: Colônia. Imagem da diferença entre as seções empilhadas com e sem a aplicação do filtro de Harlan nos dados deconvolvidos (conjuntos cdp correspondentes aos tiros fldr103 - fldr 123).

Figura 8.8.3 - Área de estudo: Colônia. Seção empilhada com a aplicação do filtro de Harlan nos dados deconvolvidos com parâmetros diferentes para os conjuntos de tiros correspondentes aos fldr maiores que 123.

Figura 8.8.4 - Área de estudo: Colônia. Imagem da diferença das seções empilhadas com e sem a aplicação do filtro de Harlan nos dados deconvolvidos (com parâmetros diferentes para os tiros correspondentes aos fldr menores e maiores que fldr123).....

Figura 9.1.1 - Área de estudo: Campus da USP. Geometria de aquisição. As posições de fontes e receptores.

Figura 9.1.2 - Área de estudo: Campus da USP. Geometria de aquisição. A posição das fontes e pontos médios comuns.

Figura 9.1.3 - Área de estudo: Campus da USP. Geometria de aquisição. Posição das fontes e pontos assintóticos de conversão comuns (ACCP) com

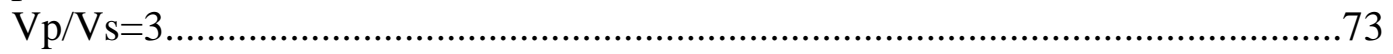

Figura 9.1.4 - Área de estudo: Campus da USP. Multiciplidade de traços a) para CDP na componente vertical; b) para ACCP nas componentes horizontais $(\mathrm{Vp} / \mathrm{Vs}=3) \ldots . . .73$

Figura 9.3.1 - Área de estudo: Campus da USP. Análise de polarização. .74

Figura 9.4.1 - Área de estudo: Campus da USP. Conjuntos de tiro das componentes a) vertical; b) horizontal radial; c) horizontal transversal e seus respectivos espectros de frequências d), e) e f)... 75 

Figura 9.4.2 - Área de estudo: Campus da USP. Espectros de amplitude da componente vertical a) e componente horizontal radial b) em uma faixa de frequências reduzida

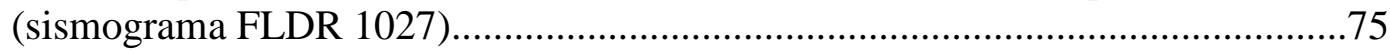

Figura 9.5.1 - Área de estudo: Campus da USP. Seção de dados empilhados sem filtrar...........76

Figura 9.5.2 - Área de estudo: Campus da USP. Seção de dados empilhados com PB aplicado ao dado sem ganho.

Figura 9.5.3 - Área de estudo: Campus da USP. Diferença das seções empilhadas do dado original com dado filtrado. .77

Figura 9.5.4 - Área de estudo: Campus da USP. Componente horizontal radial. Seção de dados empilhados sem filtrar. .77

Figura 9.5.5 - Área de estudo: Campus da USP. Componente horizontal radial. Seção empilhada sobre o ACCP com PB aplicado ao dado sem ganho.

Figura 9.5.6 - Área de estudo: Campus da USP. Componente horizontal radial. Diferença das seções empilhadas do dado original com dado filtrado.

Figura 9.6.1 - Área de estudo: Campus da USP. Espectros do sinal no domínio f-k das componentes a) vertical; b) horizontal radial e c) horizontal transversal (sismograma FLDR 1027).

Figura 9.6.2 - Área de estudo: Campus da USP. Componente Vertical. Seção empilhada de dados com filtro FK aplicado ao dado sem ganho. Parâmetros do filtro aplicado: $(\mathrm{k} / \mathrm{f})=-0.001,-0.00,0.001,0.002$ e o bias $=0.0035$.

Figura 9.6.3 - Área de estudo: Campus da USP. Componente vertical. Imagem da diferença das seções empilhadas dos dados sem filtro FK e com filtro FK aplicado ao dado sem ganho. Parâmetros do filtro aplicado: (k/f)=-0.001,- $0.00,0.001,0.002$ e bias $=0.0035$.

Figura 9.6.4 - Área de estudo: Campus da USP. Componente horizontal radial. Seção empilhada em ACCP com filtro FK aplicado ao dado sem ganho. Parâmetros do filtro aplicado, inclinações $=-0.002,-0.001,0.004,0.005$ e bias $=0.0035$. 81

Figura 9.6.5 - Área de estudo: Campus da USP. Componente horizontal radial. Imagem da diferença das seções empilhadas dos dados sem filtro FK e com filtro FK aplicado ao dado sem ganho. Parâmetros do filtro aplicado inclinações=-0.002,$0.001,0.004,0.005$ e bias $=0.0035$.

Figura 9.6.6 - Área de estudo: Campus da USP. Componente horizontal radial. Seção empilhada em ACCP com filtro FK e Mute aplicado.

Figura 9.6.1 - Área de estudo: Campus da USP. Imagens do resultado da autocorrelação dos traços (autocorrelograma) da componente vertical do sismograma. 

Figura 9.7.2 - Área de estudo: Campus da USP. Seção empilhada de dado deconvoluido. Componente vertical-Coordenadas CMP

Figura 9.7.3 - Área de estudo: Campus da USP. Autocorrelaçao de traços da componente horizontal radial.

Figura 9.7.4 - Área de estudo: Campus da USP. Seção empilhada de dado deconvolvido. Componente horizontal radial

Figura 9.8.1 - Área de estudo: Campus da USP. Gráfico da função semblance do conjunto CMP 67 antes da deconvolução e após a aplicação da deconvolução. . .84

Figura 10.1 - Área de Colônia. Seção empilhada da componente vertical. .85

Figura 10.2 - Área de Colônia: modelo geológico. a) modelo estrutural; b) seção modelada das ondas PP com parâmetros: V1 $1270 \mathrm{~m} / \mathrm{s}, \quad \mathrm{V} 2=1550 \mathrm{~m} / \mathrm{s} \quad$ e $\quad \mathrm{V} 3=1800 \mathrm{~m} / \mathrm{s}$ $\mathrm{V} 4=4500 \mathrm{~m} / \mathrm{s}, \mathrm{h} 1=40 \mathrm{~m}, \mathrm{~h} 2=97 \mathrm{~m}$ e profundidade do embasamento variando de $90 \mathrm{~m}$ a $160 \mathrm{~m}$; c) seção modelada das ondas PS com Vp/Vs=3.5

Figura 10.3 - Área de Colônia: modelo de refletividade com parâmetros: Vp1=1800m/s, $\mathrm{Vp} 2=4500 \mathrm{~m} / \mathrm{s}, \mathrm{Vs} 1=520 \mathrm{~m} / \mathrm{s}, \mathrm{Vs} 2=2250 \mathrm{~m} / \mathrm{s}$. a) coeficiente de reflexão Rpp b) coeficiente de reflexão Rps

Figura 10.4: Área de Colônia: modelo de refletividade com parâmetros: Vp1=1800m/s, $\mathrm{Vp} 2=5000 \mathrm{~m} / \mathrm{s}, \mathrm{Vs} 1=520 \mathrm{~m} / \mathrm{s}, \mathrm{Vs} 2=2500 \mathrm{~m} / \mathrm{s}$. a) coeficiente de reflexão Rpp b) coeficiente de reflexão Rps..

Figura 10.5 - Área da USP. a) seção empilhada da componente vertical; b) seção empilhada da componente horizontal radial. .88

Figura 10.6 - Área da USP: modelo geológico. a) modelo estrutural; b) seção modelada das ondas PP; c) seção modelada das ondas PS.

Figura 10.7 - Área da USP: a) Vp/Vs calculado a partir do método de Stewart (1999); b) Coeficiente de Poisson.....

Figura 1: Modelo das ondas convertidas (espaçamento entre geofones e entre fontes de $1 \mathrm{~m}$ ). Parâmetros de ACCP binning: $\mathrm{Vp} / \mathrm{Vs}=4$.

Figura 2: Modelo das ondas convertidas (espaçamento entre geofones e entre fontes de $2 \mathrm{~m}$ ). Parâmetros de ACCP binning: $\mathrm{Vp} / \mathrm{Vs}=4$.

Figura 3: Modelo das ondas convertidas com mute aplicado nos últimos traços de conjunto ACCP (espaçamento entre geofones e entre fontes de $2 \mathrm{~m}$ ). Parâmetros de ACCP binning: $\mathrm{Vp} / \mathrm{Vs}=4$. 



\section{LISTA DE TABELAS}

Tabela 8.1.1 - As faixas dos valores dos cabeçalhos introduzidos aos dados sísmicos (exemplo de

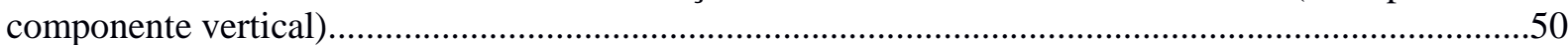

Tabela 8.1.2 - Faixas dos valores da razão Vp/Vs analisados e valores do fator G correspondentes........50

Tabela 9.1.1 - Faixas dos valores dos cabeçalhos introduzidos aos dados sísmicos (exemplo de componente vertical) 



\section{SUMÁRIO}

1 Introdução

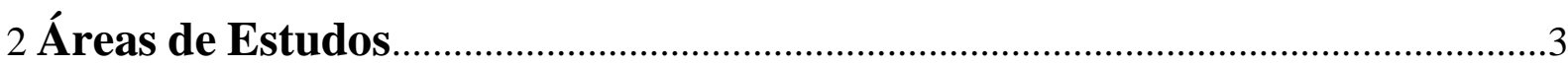

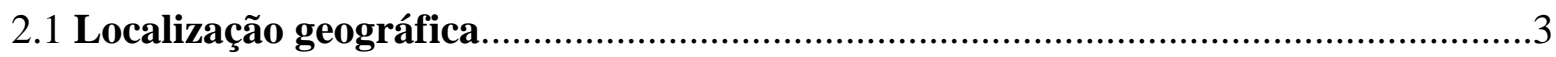

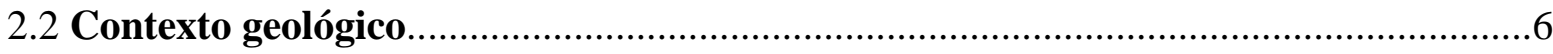

3 Método

4 Instrumentação

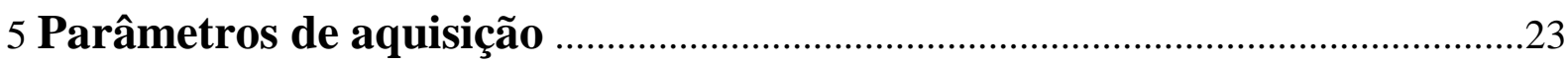

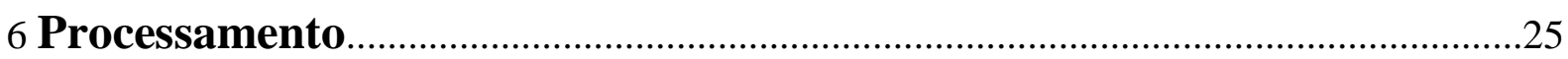

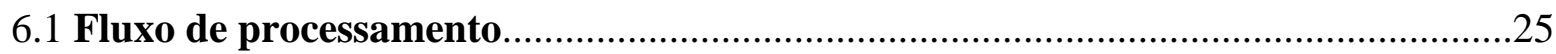

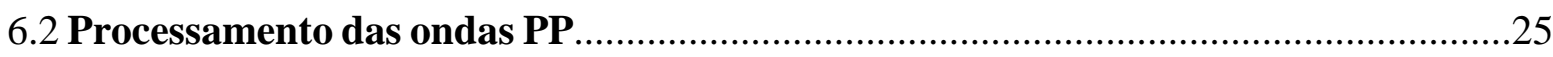

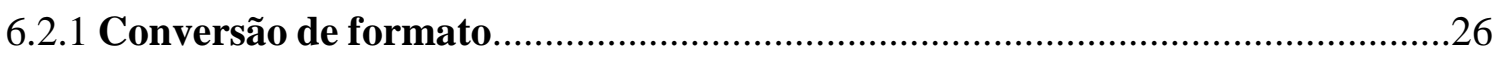

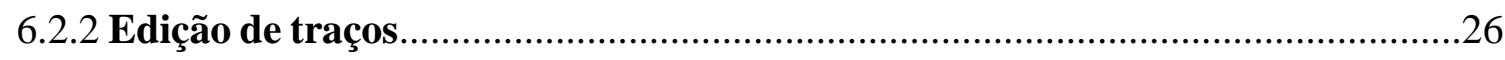

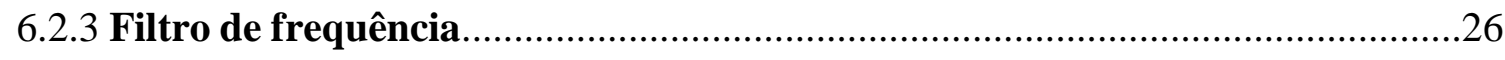

6.2.4 Geometria

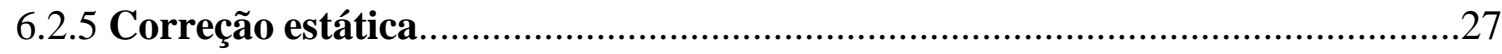

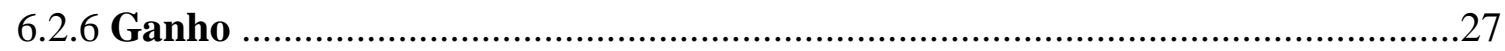

6.2.7 Processamentos relacionados à minimização dos ruídos sísmicos.......................27

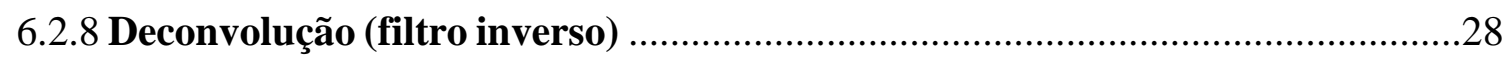

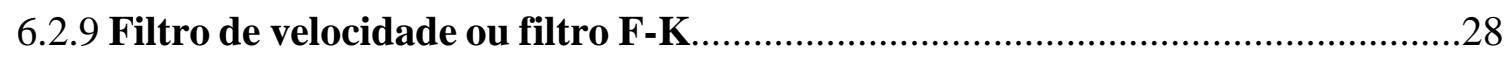

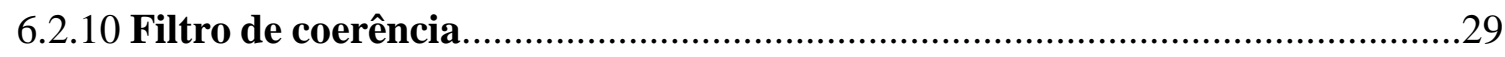

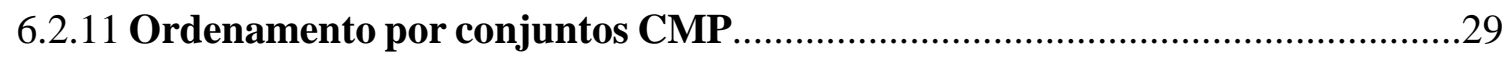

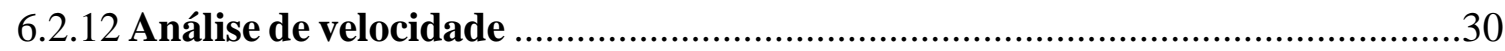

6.2.13 Correção do sobretempo normal (NMO - Normal-Moveout) ..............................30

6.2.14 Correção do sobretempo de mergulho (DMO - Dip-Moveout) ...........................31

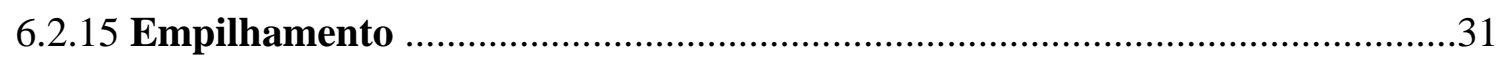

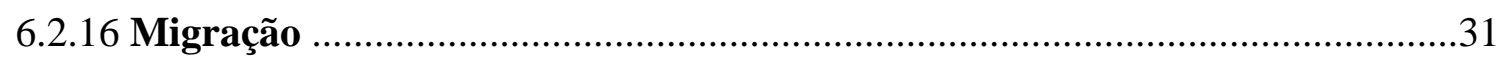

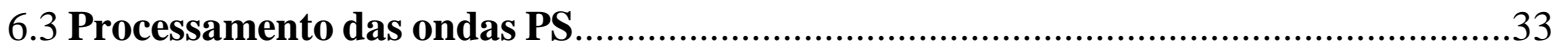

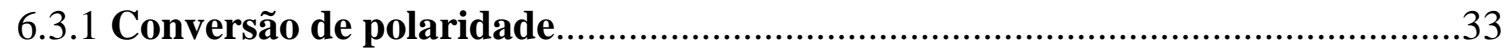

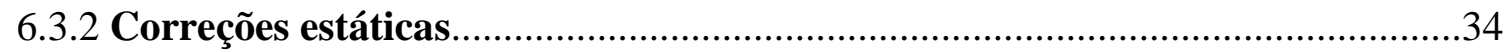

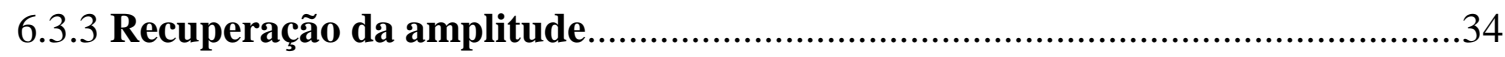





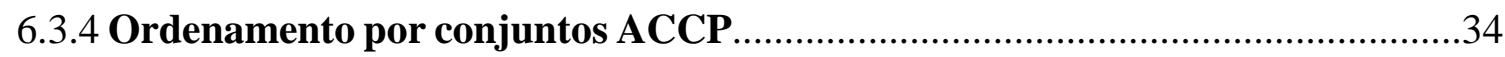

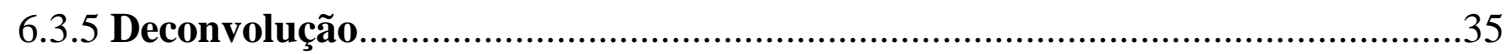

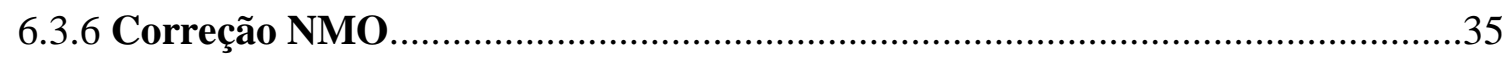

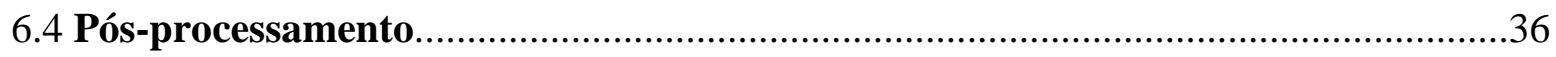

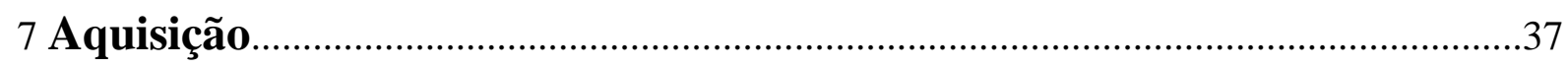

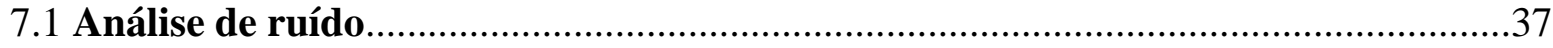

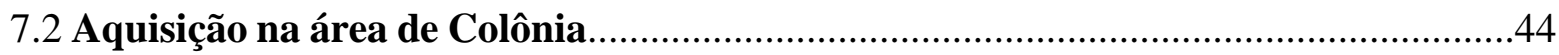

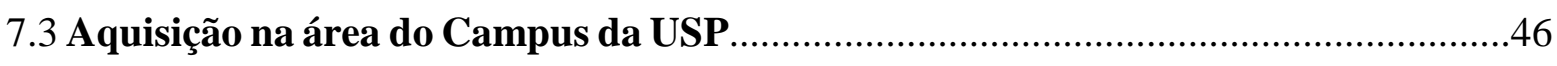

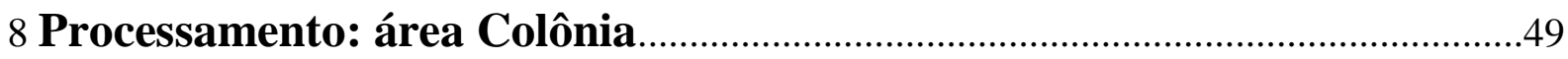

8.1 Controle de qualidade da geometria e cálculo de ACCP........................................49

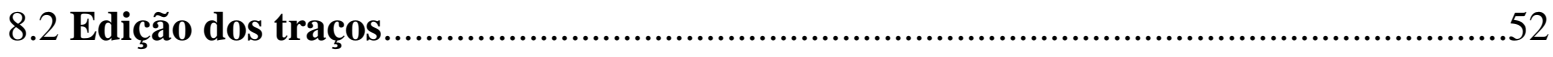

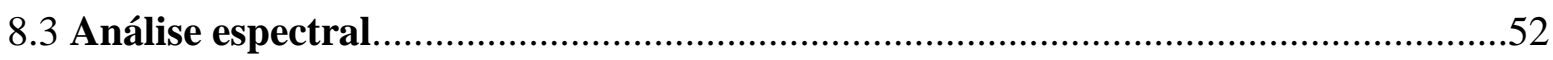

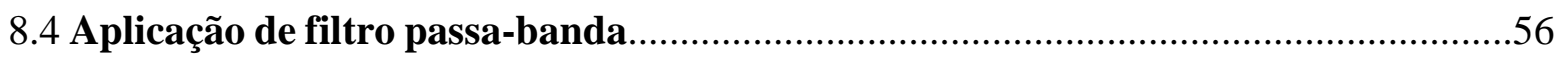

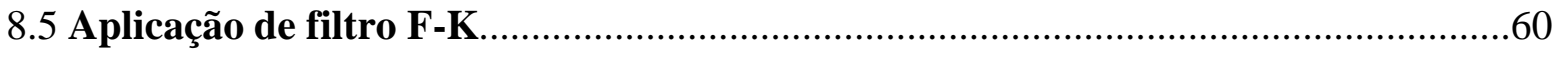

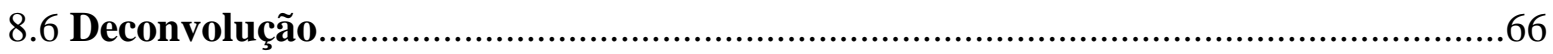

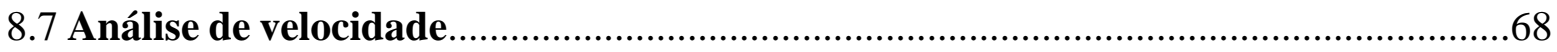

8.8 Aplicação de filtro Harlan (filtro de coerência) .....................................................68

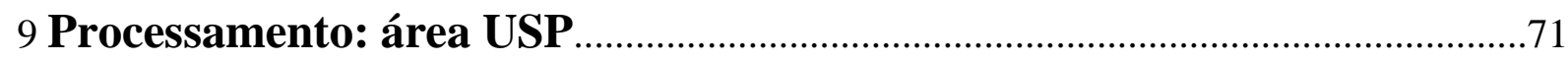

9.1 Controle de qualidade da geometria e cálculo de ACCP........................................73

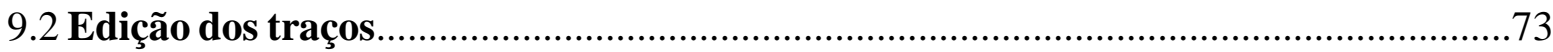

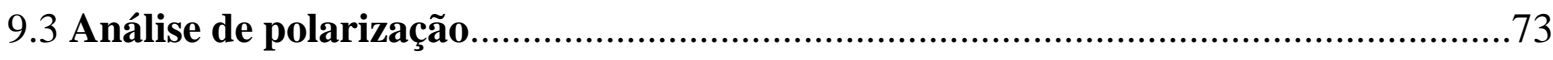

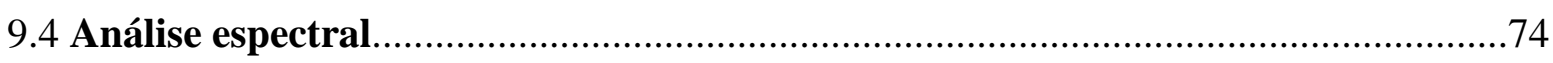

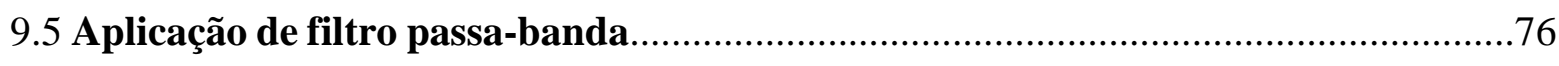

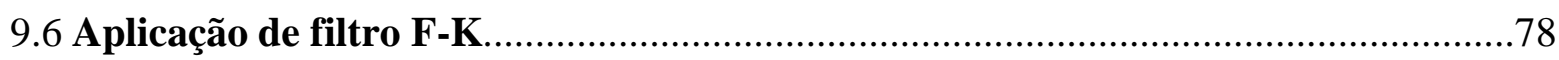

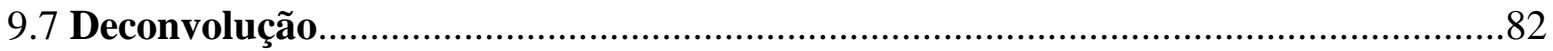

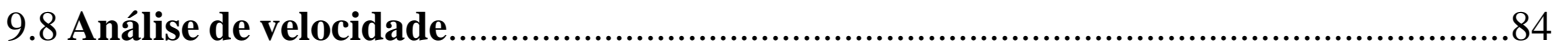

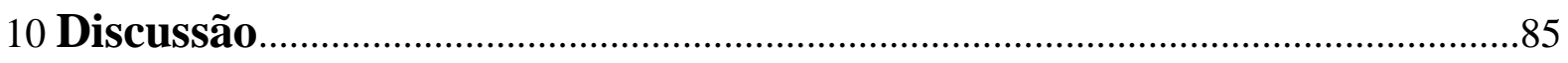

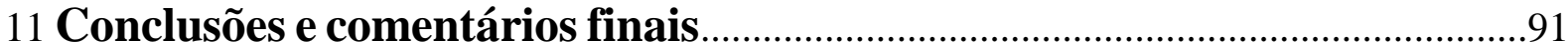

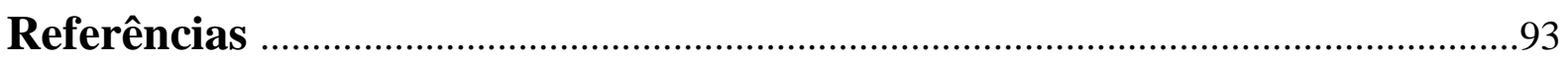

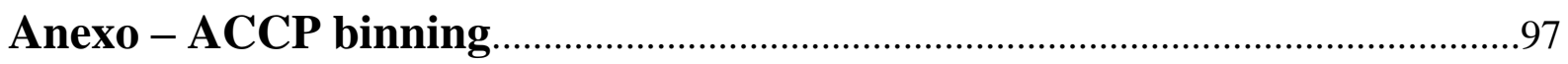





\section{Introdução}

Diversos métodos são empregados para estudar o subsolo da terra. O método da sísmica de reflexão, especialmente na exploração na indústria de óleo e gás, é dos mais empregados devido a sua superior resolução. Nos anos mais recentes, foi introduzido na indústria de óleo e gás a sísmica multicomponente, que apresentou acelerado desenvolvimento. A introdução ao emprego desse método foi motivada, em parte, pela resposta limitada do imageamento exclusivo da onda P observada em alguns reservatórios (Farfour e Yoon, 2016). Além disso, a resposta da onda de cisalhamento (S), obtida através do registro das ondas convertidas, PSv, (propagação descendente da onda $\mathrm{P}$ e ascendente da onda $\mathrm{S}$ ) poderia oferecer informações adicionais sobre algumas propriedades petrofísicas dos reservatórios, ou complementar as informações usualmente obtidas através da onda P (Hardage, 2017).

Na prática já foi demonstrada a efetividade da metodologia para amplos objetivos, tais como: geração de imagens em situações de fraca refletividade PP, melhora da imagem da subsuperfície mais rasa $(<1000 \mathrm{~m}$ de profundidade), caracterização de fraturas (orientação e densidade), caracterização de litologia, discriminação de fluidos, e imageamento das falhas a partir da interpretação conjunta dos campos de ondas PP e PS (Gaiser et al., 2001; Chopra e Stewart, 2010; Stewart et al., 2008). Nos casos de topografia com pronunciadas inclinações, os benefícios potenciais de usar receptores 3C são de obter uma imagem de reflexão das ondas $\mathrm{P}$ melhorada, sem perdas da amplitude devido ao ângulo emergente no sensor (Hall et al., 2015).

Apesar das vantagens que o registro de um campo de ondas mais completo pode trazer para a investigação da subsuperfície, o levantamento de sísmica de reflexão de ondas convertidas (PS) ainda não é usado amplamente como o levantamento das ondas compressionais (PP) (Stewart et al., 1999; Garota et al., 2002, Pugin et al.,2013). As razões principais dessa lenta aceitação estão relacionadas a diversos fatores, entre os quais estão: maior volume de dados, a complexidade de processamento e da interpretação.

O grande potencial do emprego das ondas convertidas para a investigação geológica motivaram este estudo, porém com foco na investigação rasa. Esta pesquisa trata, portanto, da investigação sísmica com o emprego do método de sísmica de reflexão multicomponente (3C), especialmente em relação à resposta das ondas convertidas (PSv). Este estudo aborda aspectos relacionados à aquisição, processamento e interpretação de dados. 
Para realizar a análise da resposta do subsolo foram escolhidos dois locais, ambos na cidade de São Paulo-Brasil mas que apresentam características geológicas e petrofísicas distintas. Além disso, por se tratar de áreas urbanas, o nível de ruídos traz um desafio extra.

O primeiro conjunto de dados foi adquirido em área da estrutura de Colônia (Riccomini et al., 1991), caracterizada por um pacote sedimentar onde predominam argilas siltosas ricas em matéria orgânica e lamas arenosas, e onde o nível freático é bastante raso (subaflorante).

O segundo conjunto de dados foi adquirido dentro do campus (CUASO) da Universidade de São Paulo - USP, onde o pacote sedimentar é caracterizado predominantemente por argilas siltosas, areias, e areias siltosas com escassa presença de argilas siltosas ricas em matéria orgânica, e nível freático a alguns metros da superfície (Porsani et al. (2004).

Para realizar o processamento dos dados foi utilizado o pacote Seismic Unix (CWP/SU) (Stockwell e Coher, 2002)

Em termos gerais, esta dissertação está organizada da seguinte forma: i) descrição das áreas de estudo; ii) aspectos metodológicos (aquisição e processamento); iii) descrição dos ensaios e do fluxo de processamento realizados para os dois conjuntos de dados; iv) discussão dos resultados; v) conclusões. 


\section{2 Áreas de Estudos}

\subsection{Localização geográfica}

Para aquisição dos dados foram escolhidas duas áreas com características geológicas diferentes: i) Cidade Universitária (campus da Universidade de São Paulo - USP), situada na zona oeste do Município de São Paulo, estado de São Paulo, Brasil; ii) área da estrutura de Colônia situada na região de Parelheiros, na zona periférica do Município de São Paulo, estado de São Paulo, Brasil (Figura 2.1.1).

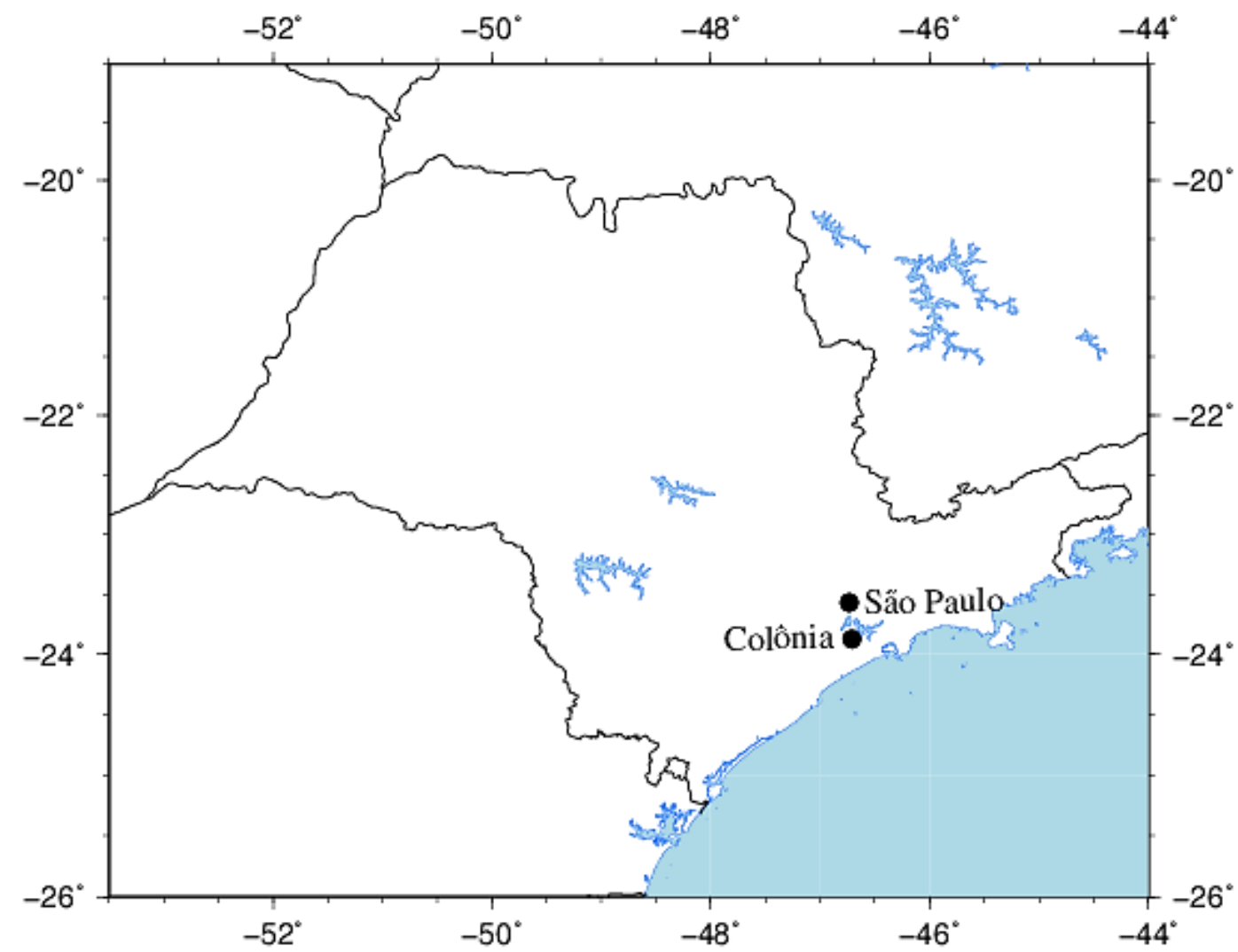

Figura 2.1.1: Mapa de estado de São Paulo. Os pontos indicam a localização das áreas de estudos.

A estrutura de Colônia, conhecida como "Cratera de Colônia" localiza-se integralmente dentro dos limites do Município de São Paulo, na região sul, a $35 \mathrm{~km}$ da Praça da Sé, centro da cidade de São Paulo, na região de Parelheiros (Figura 2.1.1 e Figura 2.1.2).

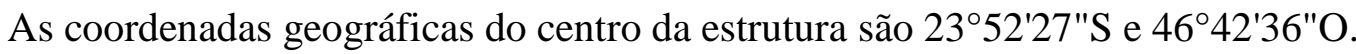

A discussão de origem da estrutura de Colônia remonta-se até os anos 60, quando por primeira vez foram aplicados métodos geofísicos, gravimétricos e geoelétricos, em conjunto 
com analise de morfologia na depressão por Kollert et al. (1961). Como resultado desses estudos foi sugerido que a depressão poderia ser causada por dissolução de rochas calcárias ou por impacto meteorítico. O último foi sustentado no tempo, devido à notável ausência das rochas calcárias na área.

A Cratera de Colônia é uma das duas crateras habitadas no mundo sendo a outra a de Ries na Alemanha. Diferentemente da cratera Ries, a de Colônia foi povoada recentemente, no início da década de 1990. Na Figura 2.1.2a é possível observar os bairros de Vargem Grande, na parte Norte e situado no interior da Cratera, e o de Colônia, na borda NE, que ocupa a parte externa do anel. Área significativa do assentamento Vargem Grande está em uma região de várzea, não apropriada para assentamento devido à proximidade do lençol freático (Santos, 2013).

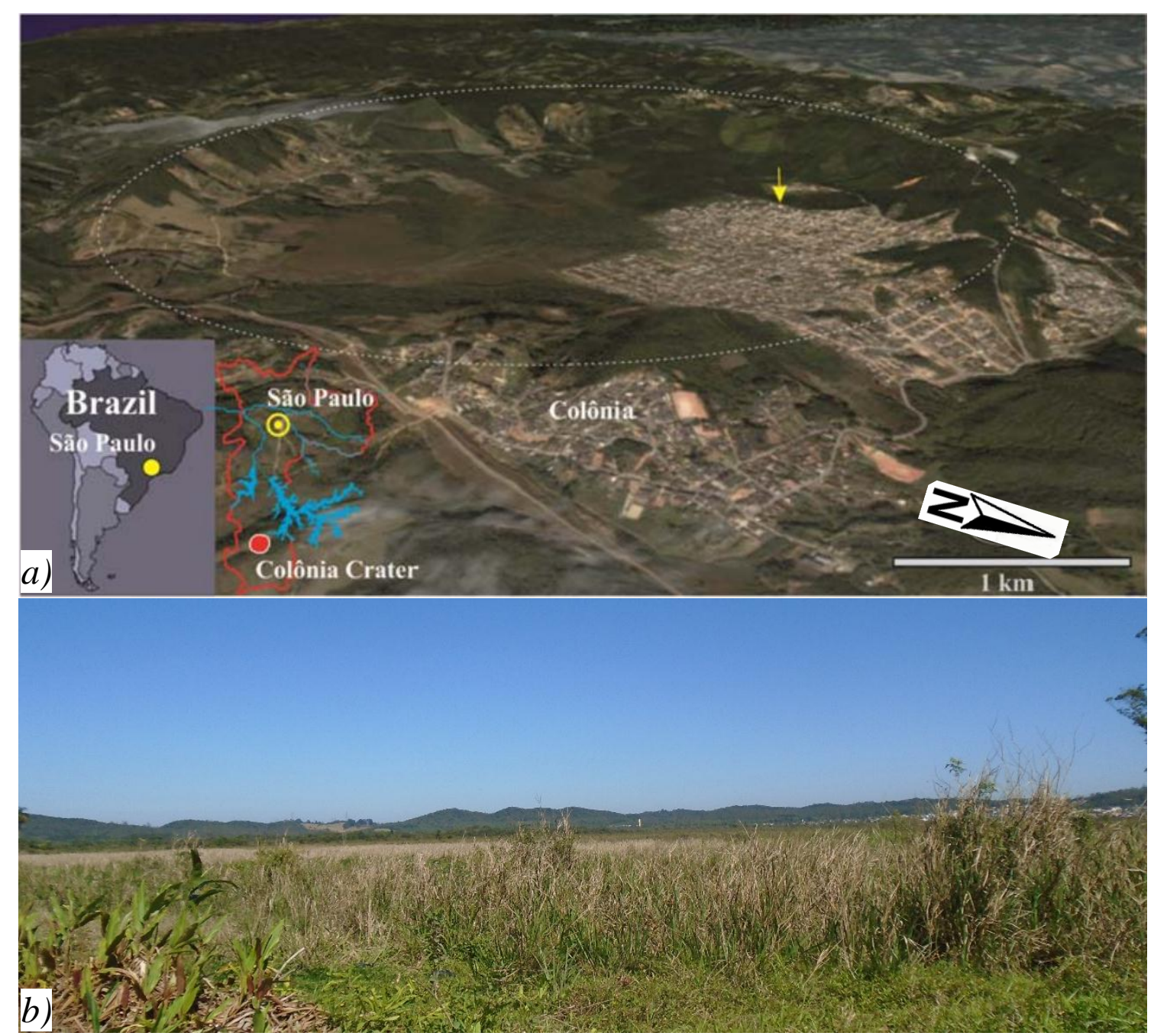

Figura 2.1.2: a) Aspecto morfológico da cratera de Colônia. O círculo pontilhado delineia o anel externo colinoso da cratera. A seta amarela indica o local da sondagem realizada para exploração de água subterrânea (Fonte: modificado de Velázquez et al., 2013); b) Fotografia do interior da Cratera de Colônia. 
Águas do uso doméstico são frequentemente escoadas nas ruas do assentamento e alcançam o centro da cratera, que tem as características de um pântano na maior parte do ano, e são drenadas pelo arroio Vargem Grande. O arroio exibe um padrão peculiar radial centrípeto com uma única saída através da borda leste da estrutura (Riccomini et al., 2011).

A segunda área de estudo situa-se na Cidade Universitária (Figura 2.1.1 e Figura 2.1.3), zona oeste do Município de São Paulo, Brasil (coordenadas geográficas 23³3'60"S e 4644'4"O). É uma área urbanizada com intenso tráfego de veículos.

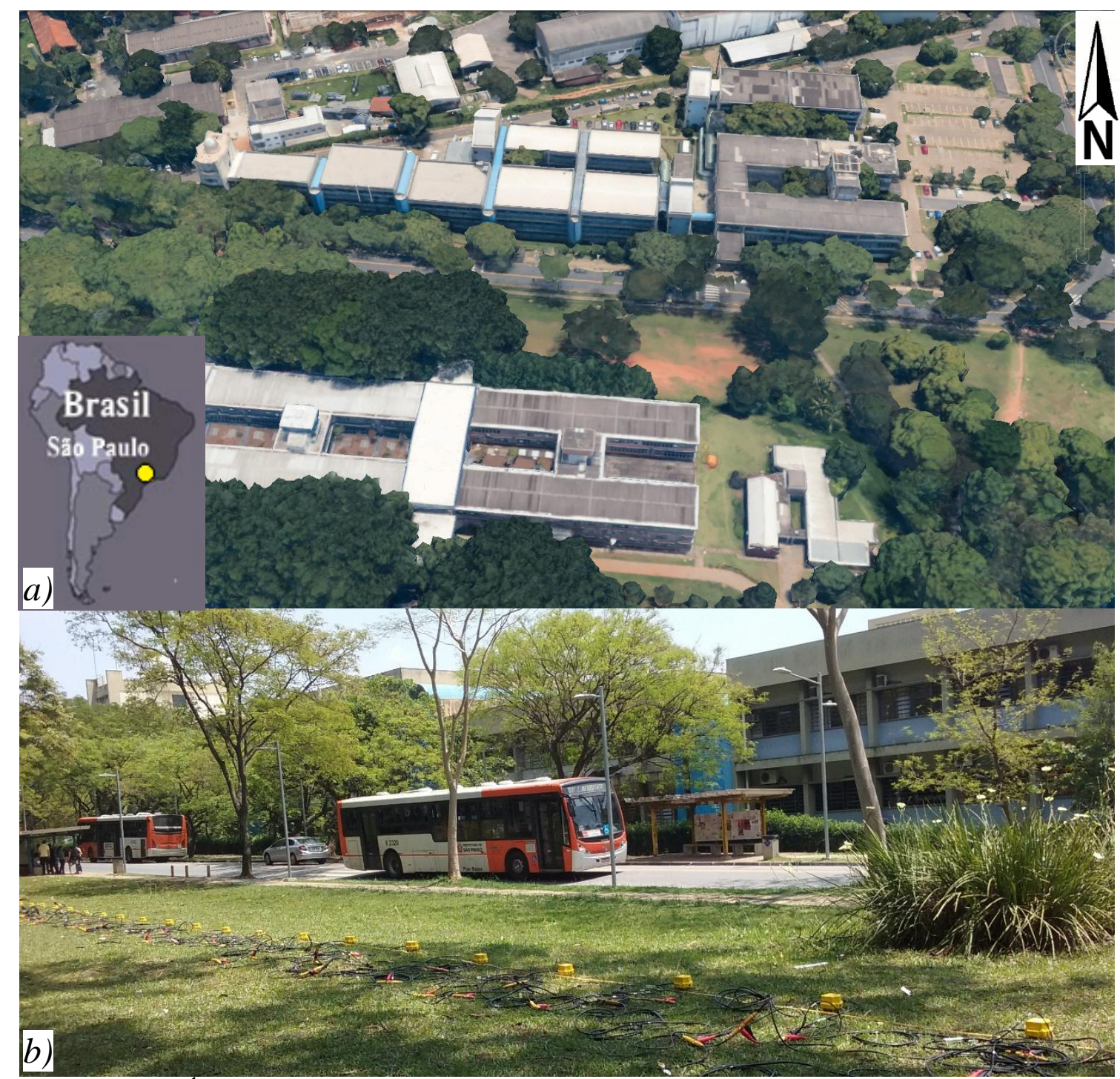

Figura 2.1.3: a) Área de estudo no Campus da Universidade de São Paulo (USP); b) Fotografia da área de estudo. 


\subsection{Contexto geológico}

Considerando a tectônica regional, as duas áreas de estudos ficam compreendidas em uma zona orogenicamente complexa de idade neoproterozóica, conhecida como Cinturão de Dobramentos Ribeira (Hasui et al., 1975). Este Cinturão representa uma importante manifestação da Orogênese Brasiliana produzida durante a formação do supercontinente Gondwana, parte Ocidental (Hakcpatcher et al., 2000). Este segmento do Cinturão é caracterizado por uma complexa rede de falhamentos transcorrentes, com direções EWENE, ativos até o final do Ciclo Brasiliano (Sadowski e Campanha, 2004).

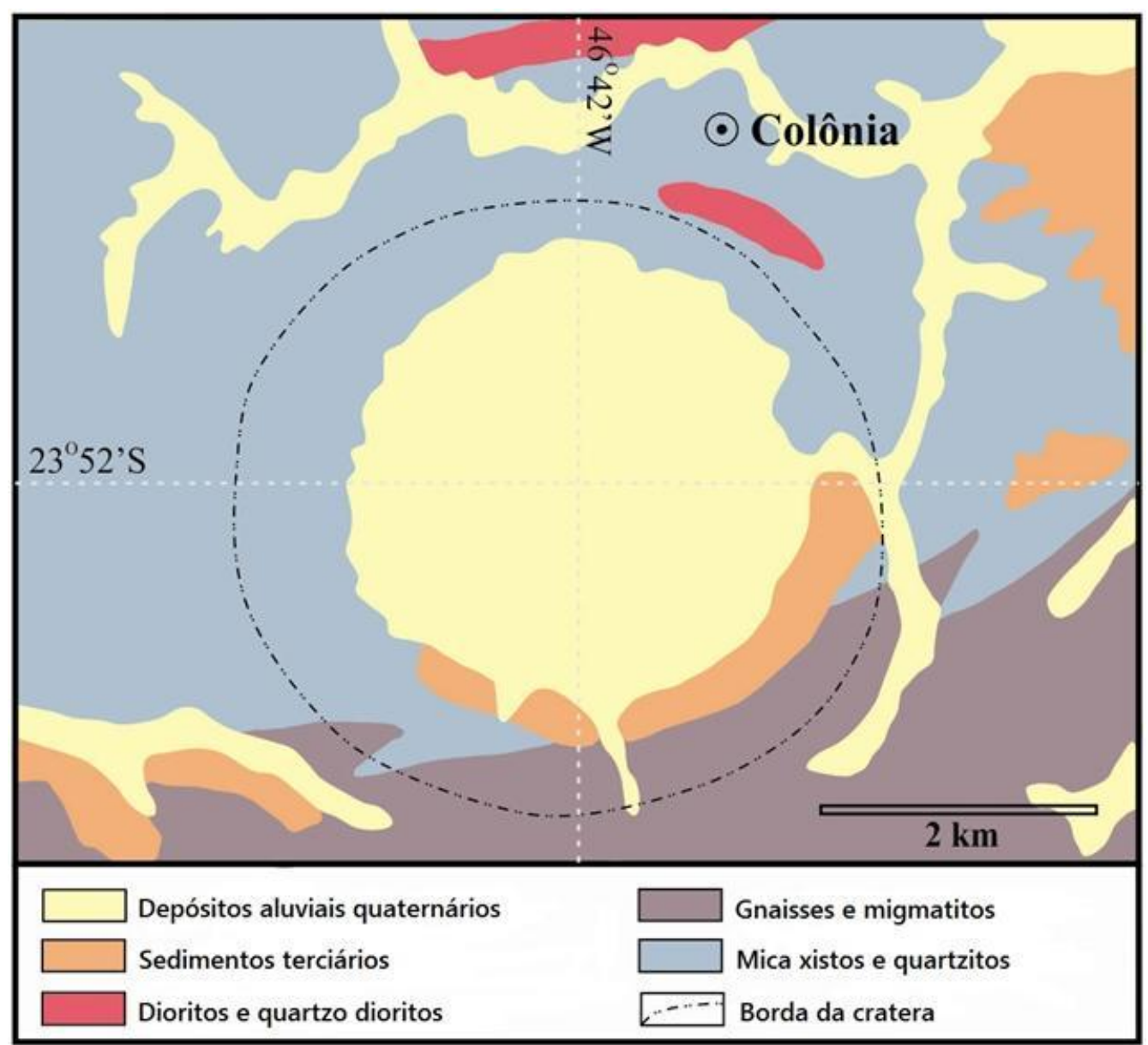

Figura 2.2.1: Mapa geológico simplificado da estrutura de Colonia. Fonte: Modificada de Velázquez et al. (2013).

Considerando a geologia local, A Cratera de Colônia fica compreendida em uma região onde podem ser distinguidas três unidades litoestratigráficas: embasamento cristalino formado no Pré-Cambriano com tendência estrutural geral ENE, sedimentos Terciários e 
depósitos coluviais e aluviais Quaternarios (Riccomini et al., 1991; Velázquez et al., 2013). Segundo Sadowski (1974) e Coutinho (1980), os principais litotipos observados na área no embasamento cristalino são: micaxistos, quartzitos, gnaisses, migmatitos, dioritos e quartzo dioritos (Figura 2.2.1). Ao sul e sudeste da parte interior da estrutura são observados lamitos correlacionados à formação Resende, de idade Paleogênica, da Bacia Sedimentar de São Paulo, com uma distribuição semicircular (Riccomini et al., 1991). Todas as rochas encontram-se muito intemperizadas, dificultando observações geológicas (Riccomini et al., 1991). No trabalho de Kollert et al. (1961) as profundidades máximas de estrutura foram estimadas em 400m (gravimetria) e 285 m (com SEVs) no trabalho de Motta e Flexor (1991) a prof. máxima foi estimada em 300m (gravimetria)

A Figura 2.2.2 traz o perfil litológico do pacote de sedimentos quaternários que preenchem a estrutura circular de Colônia, obtido de uma sondagem realizada para exploração de água subterrânea (Figura 2.1.2a).

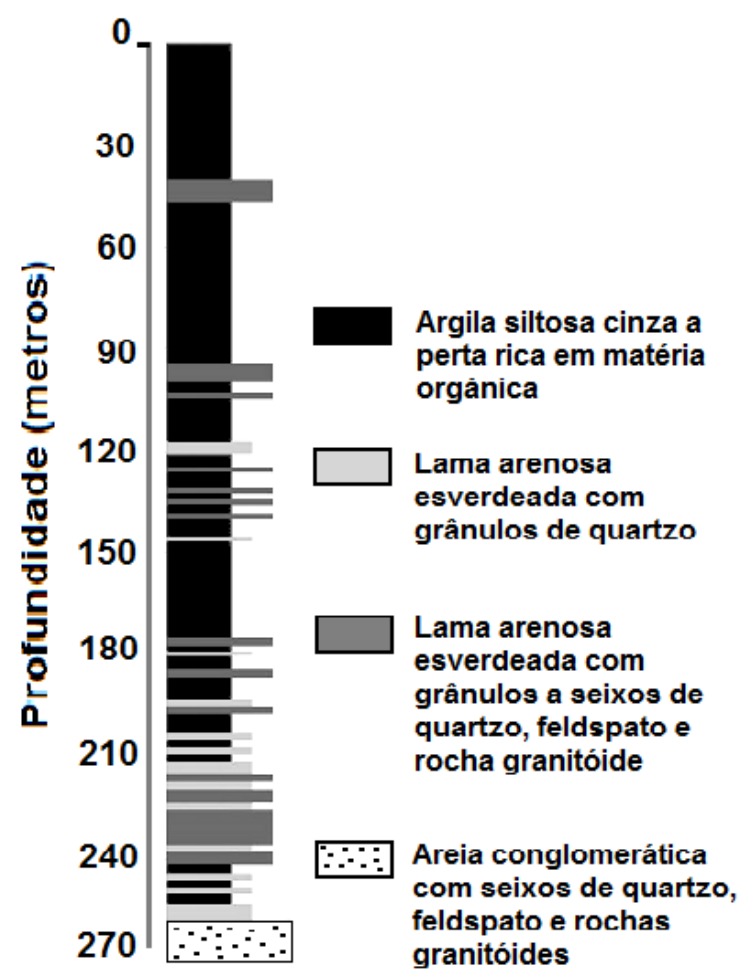

Figura 2.2.2: Perfil descritivo do pacote sedimentar obtido de uma sondagem realizada para exploração de água subterrânea na Região de Colônia. Fonte: Modificada de Riccomini et al. (2011). 
A área do campus da USP fica localizada próxima à borda oeste da Bacia Sedimentar de São Paulo, acolhidas pelo segmento central de RCSB, ocorrendo, portanto, granitosgnaisses do embasamento e sedimentos da bacia (Riccomini et al., 2004).

A Figura 2.2.3 mostra o local onde foram realizados os ensaios sísmicos com a posição das três sondagens realizadas para pesquisas geológicas e geofísicas realizados por Porsani et al. (2004), a partir das quais foi feita a descrição litológica dos sedimentos (Figura 2.2.4). As unidades que podem ser observadas são: aterro, composto principalmente de argila arenosa a siltosa e silte, com espessura variável de 4,5 m a 6,0 m; sedimentos terciários da Bacia de São Paulo argilosos e arenosos, intercalados entre si; embasamento cristalino granito-gnáissico pré-cambriano. No local dos ensaios o embasamento não supera a profundidade de $53 \mathrm{~m}$.

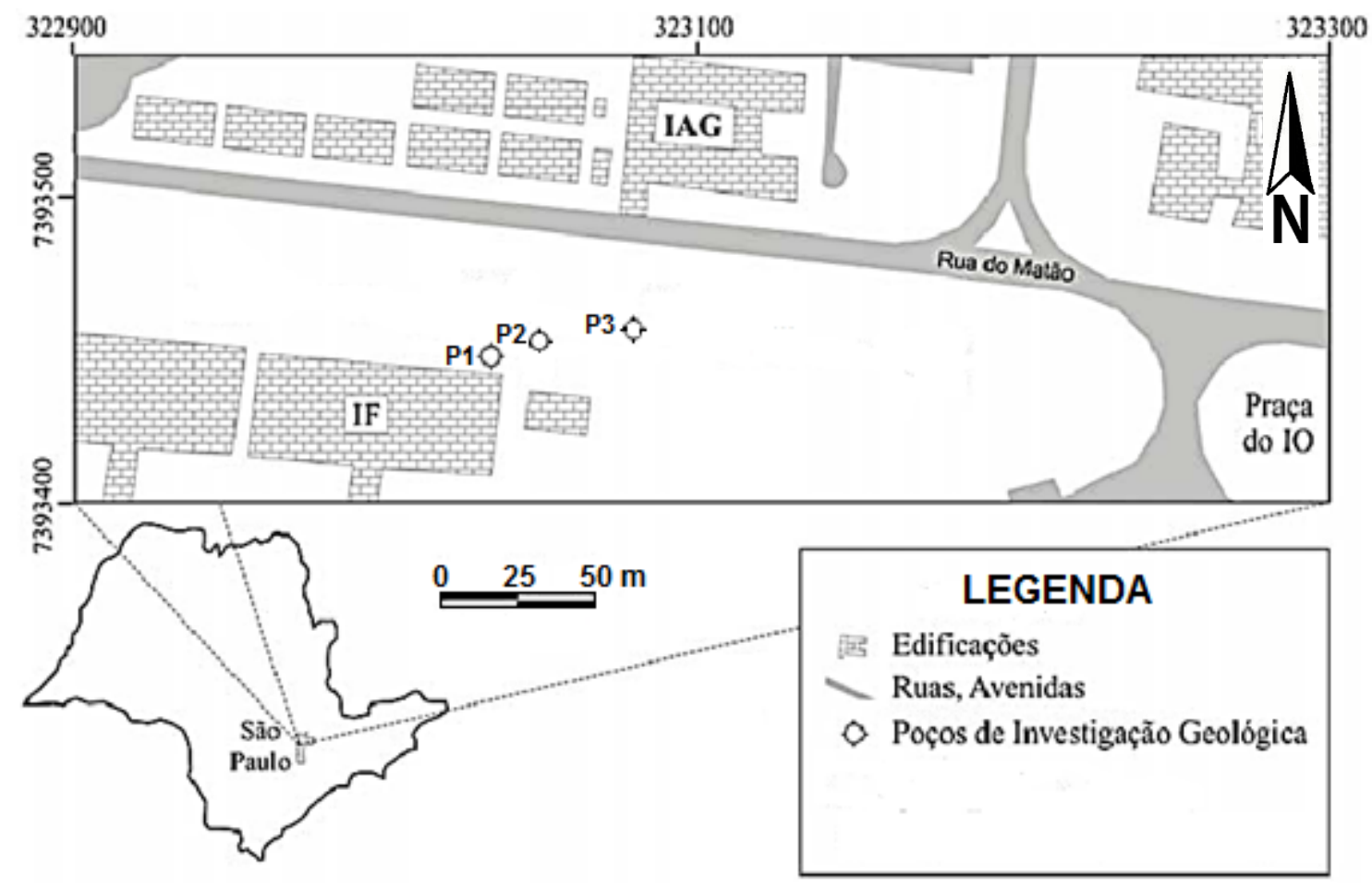

Figura 2.2.3: Mapa de localização da área estudada e dos poços para pesquisas geofísicas. Fonte: Modificada de Porsani et al. (2004). 
Distância (metros)

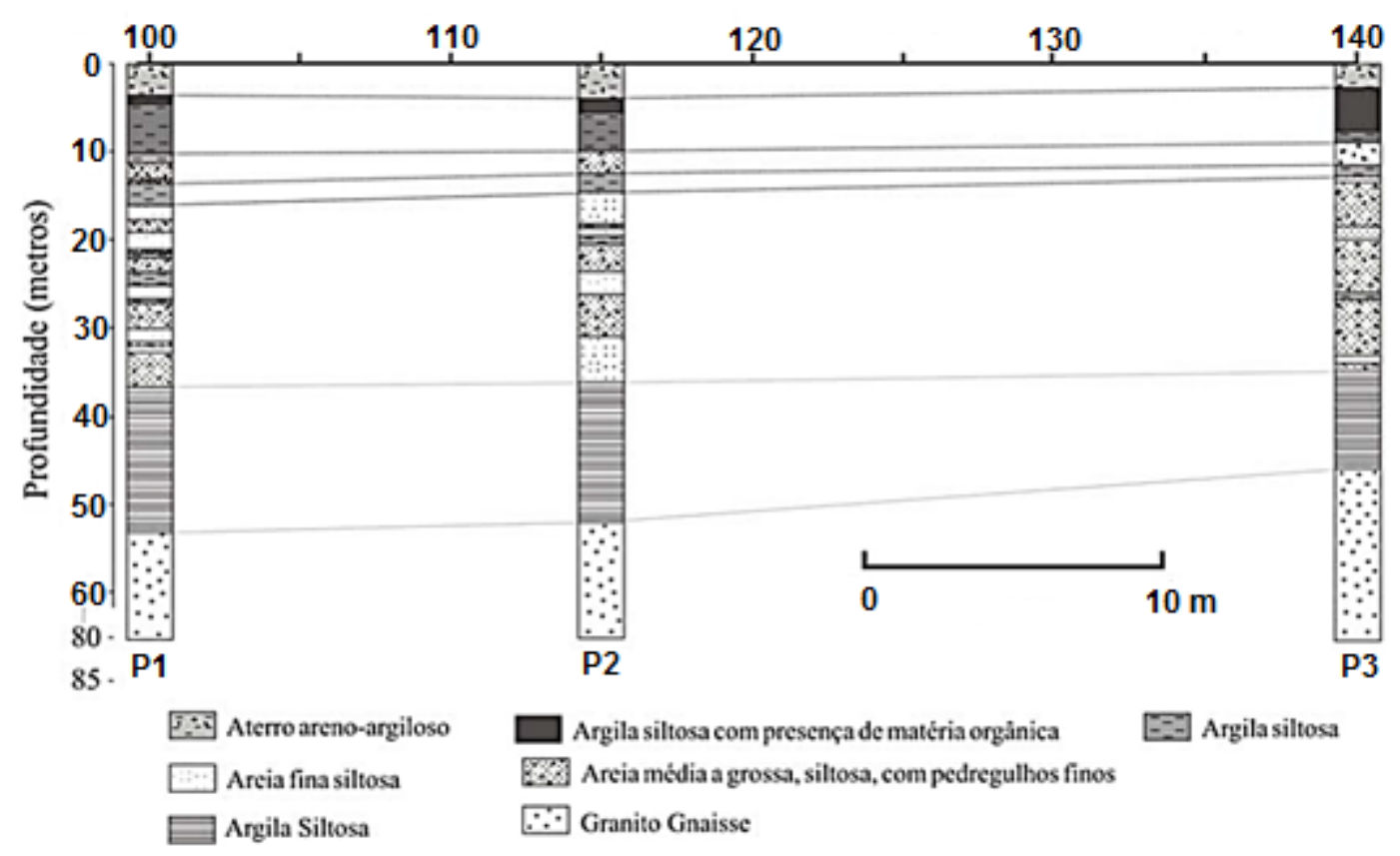

Figura 2.2.4: Correlação entre os perfis litológicos dos poços. Fonte: Porsani et al. (2004). 


\section{Método}

O método sísmico de reflexão é baseado no estudo de campos de ondas elásticas que se propagam no subsolo e se refletem nas interfaces geológicas. Tem o objetivo de mapear as estruturas e litologias do meio geológico. Neste capítulo discute-se alguns aspectos básicos relacionados ao método de reflexão no contexto deste estudo: modos de ondas elásticas e suas velocidades, ponto de reflexão, amplitude da onda refletida, resolução horizontal e vertical e birrefringência das ondas $\mathrm{S}$.

Uma onda que se propaga por um meio pode ser analisada do ponto de vista vetorial. Se definem três modos de propagação das ondas: modo compressional (onda P), onde as vibrações das partículas do meio coincidem com a direção de propagação, e dois modos cisalhantes (onda $\mathrm{S}$ ) com as vibrações das partículas contidas em planos normais à direção de propagação (Figura 3.1). A movimentação real das partículas na passagem da onda S pode ter qualquer direção dentro do plano normal ao raio e é descrita mediante as projeções nas duas ordenadas ortogonais: radial (Sv) e transversal (Sh) (Tatham, 1991; Hardage, 2011). Num meio fraturado a onda $\mathrm{S}$ sofre partição da energia em duas componentes ortogonalmente polarizadas, a componente rápida, paralela à direção da fratura, e a lenta, ortogonal ao plano da fratura.

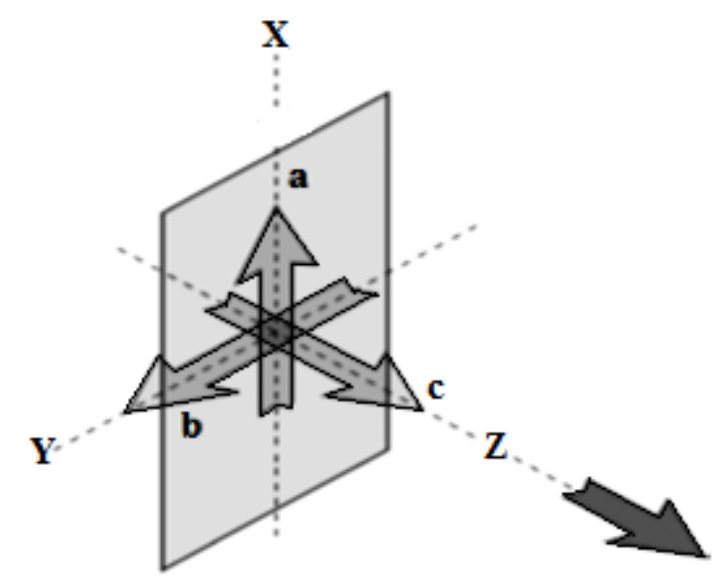

Figura 3.1: Decomposição da movimentação de partículas na passagem de uma onda em um meio homogêneo e isótropo. Plano cinza é a frente de onda, seta cinza escuro na direção $Z$ é a direção de propagação e os vetores $a, b$ e $c$, são os vetores de deslocamento. Fonte: modificada de Hardage (2011).

A velocidade de propagação das ondas $\mathrm{P}$ e ondas $\mathrm{S}$ dependem das propriedades físicas do meio. Para um meio homogêneo e isótropo, a onda $\mathrm{P}$ depende da densidade $(\rho)$, módulo de 
incompressibilidade $(K)$ e de rigidez do meio ( $\mu$ ) (Equação 3.1), que se traduzem na resistência a mudanças na forma e tamanho do meio. A velocidade da onda $\mathrm{P}$ também pode ser descrita mediante as constantes de Lamé $(\lambda$ e $\mu)$, onde $\lambda$ é uma constante sem significado físico e $\mu$ a rigidez do meio. A onda $\mathrm{S}$ depende da densidade e da rigidez do meio que se traduz na resistência à mudança na forma do meio. Essas diferenças na resposta do subsolo à propagação das ondas $\mathrm{P}$ e das ondas $\mathrm{S}$ são a base para a interpretação da litologia e propriedades de fluido a partir dos atributos das ondas tais como a razão Vp/Vs e a Razão de Poisson.

$$
\begin{aligned}
& V_{p}^{2}=\frac{\lambda+2 \mu}{\rho}=\frac{K+\frac{4}{3} \mu}{\rho} \\
& V_{s}^{2}=\mu / \rho
\end{aligned}
$$

A resposta de subsolo pode ser aproximada pelo modelo convolutivo, onde um traço sísmico define-se como a convolução da ondícula (wavelet) da fonte com a série refletiva do subsolo mais ruído (Figura 3.2). Sendo os coeficientes de reflexão a razão entre a amplitude do raio refletido e a amplitude do raio incidente.

Esta pesquisa está focada no estudo das ondas convertidas, ou seja, na propagação descendente de campo de onda P e ascendente da onda S (PSv). As ondas convertidas PS são mais simples de serem registradas e têm melhor relação sinal/ruído (SNR) que as ondas SS (propagação descendente e ascendente de onda $S$ ).

As ondas convertidas do tipo PSv têm sua origem quando uma onda P incide numa interface e se produz a conversão parcial de energia para a onda Sv (Figura 3.3). A partir da lei de Snell (Equação 3.3), se observa que devido à velocidade da onda $\mathrm{S}\left(V_{S}\right)$ ser menor que a velocidade da onda $\mathrm{P}\left(V_{p}\right)$, o ângulo da onda $\mathrm{S}$ refletida $\left(\phi_{1}\right)$ é menor que o ângulo da onda $\mathrm{P}$ incidente $\left(\theta_{1}\right)$.

$$
\frac{\sin \theta_{1}}{V_{p}}=\frac{\sin \phi_{1}}{V_{s}}
$$




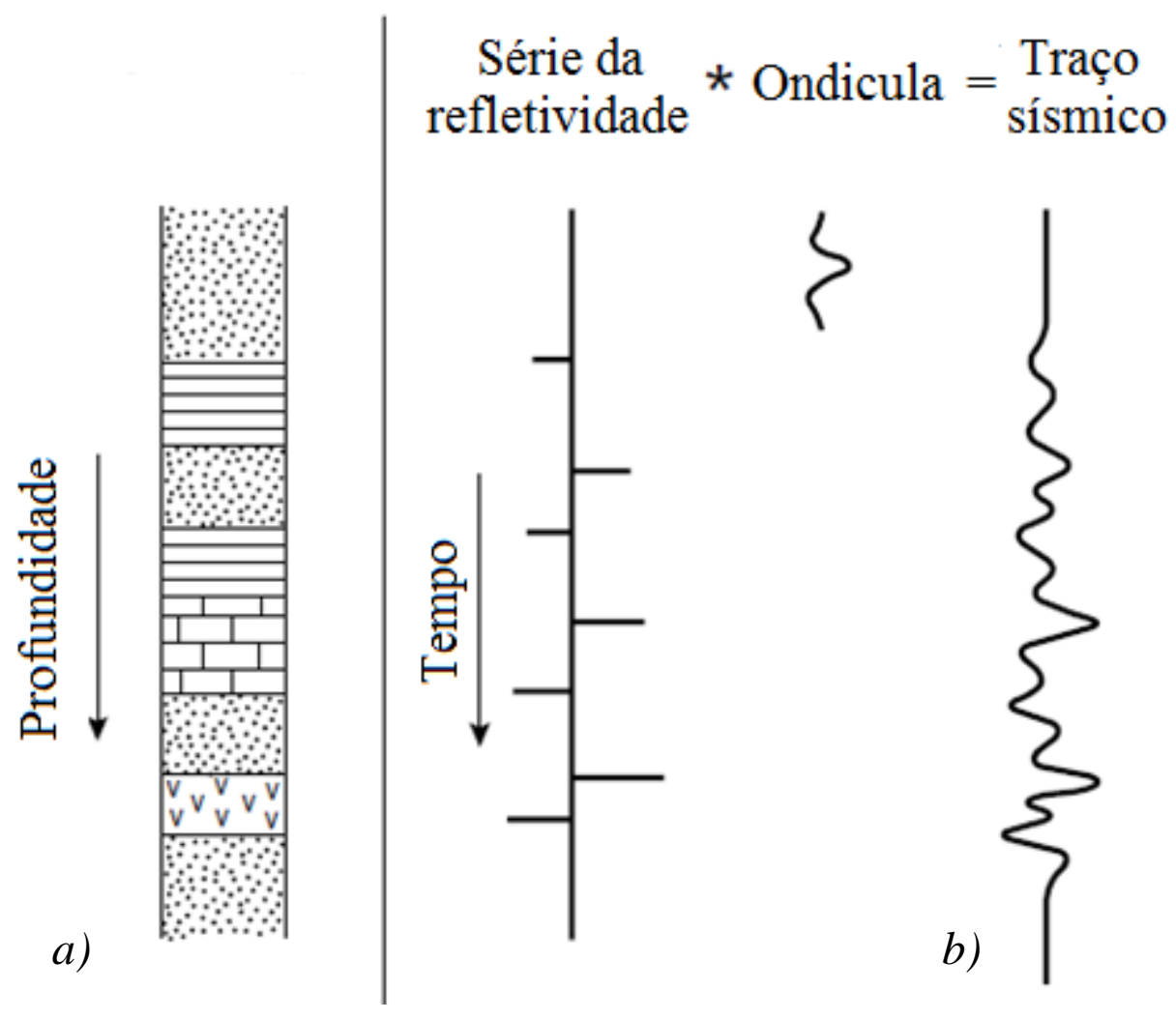

Figura 3.2: O modelo convolutivo de subsolo: a) o exemplo de uma coluna estratigráfica b) o traço sísmico resultante a partir da convolução de coeficientes de reflexão e a ondícula injetada no subsolo. Fonte: modificada de Kearey et al. (2002)

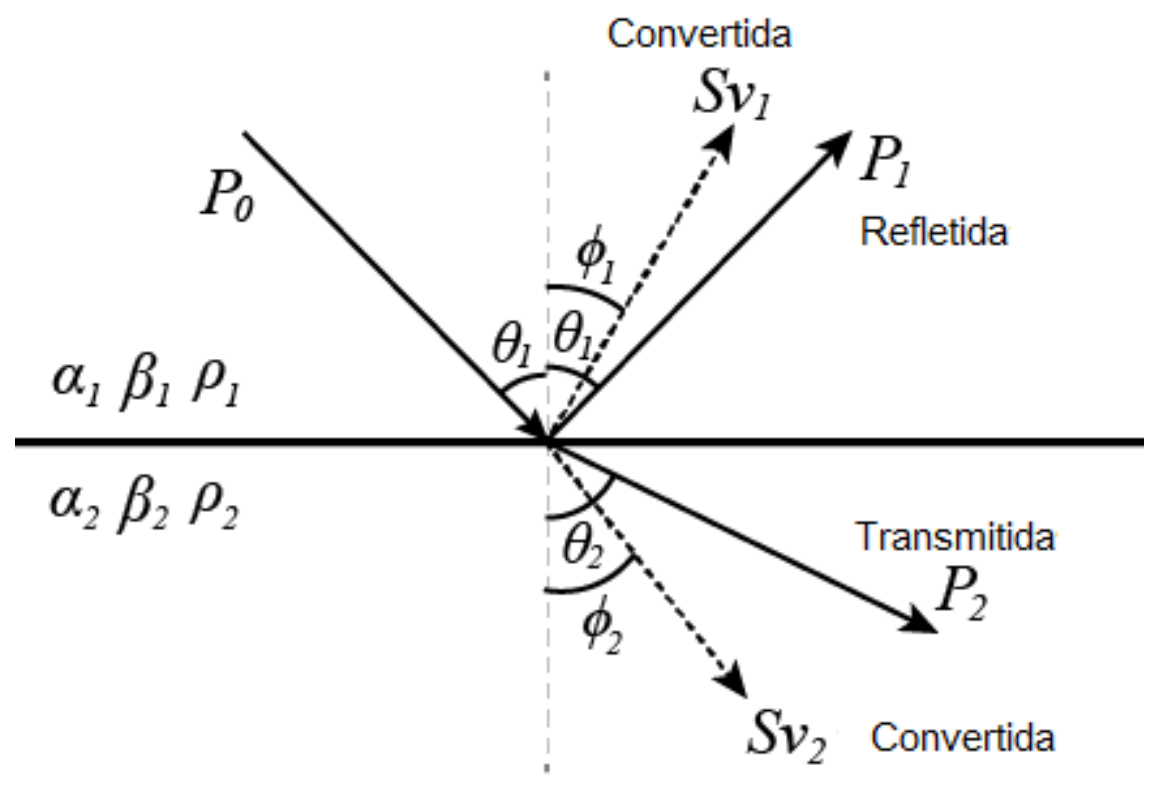

Figura 3.3: Reflexões e refrações geradas a partir de uma onda P incidente em una interface entre dois meios com diferentes propriedades físicas. Fonte: modificada de Y. Hao (2015). 
Essa assimetria do raio sísmico da onda PSv gera uma variação no ponto de reflexão com a profundidade em função das velocidades das ondas P e S para cada offset dado (Stewart et al., 2002). No caso das ondas convertidas, o ponto de reflexão também é chamado de ponto de conversão (CP) (Figura 3.4). Para as reflexões rasas e razão $\mathrm{Vp} / \mathrm{Vs}$ grande, as coordenadas do ponto de conversão projetado na superfície são próximas às do receptor (Gaiser et al., 2000).

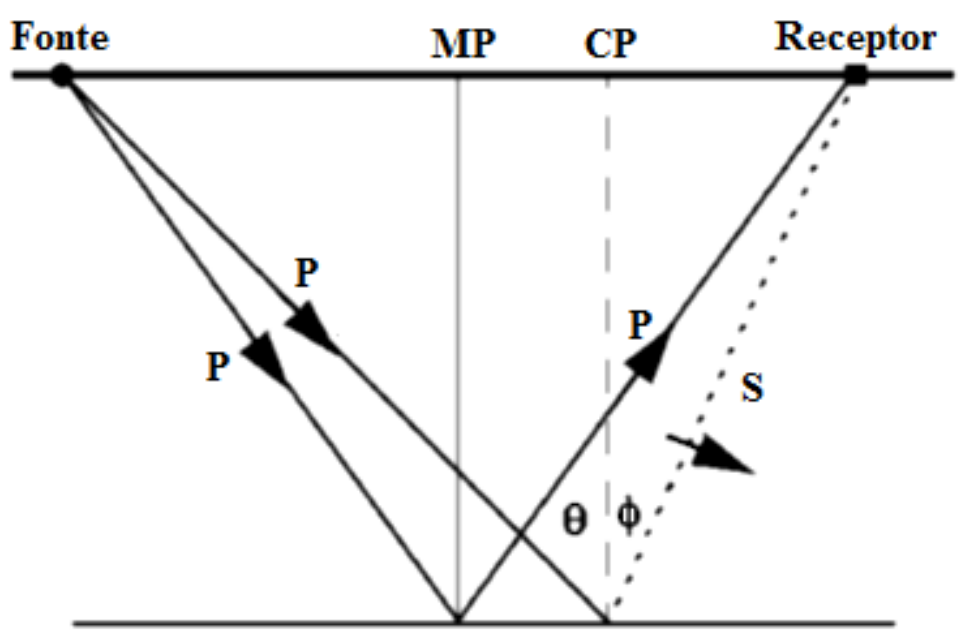

Figura 3.4: Raios sísmicos das ondas PP e PSv. MP indica o ponto meio e CP indica o ponto de conversão.

O tempo de propagação da onda convertida pode definido como:

$$
t_{x}=\sqrt{t_{P O}^{2}+\frac{x_{P}^{2}}{V_{P}^{2}}}+\sqrt{t_{S O}^{2}+\frac{x_{S}^{2}}{V_{S}^{2}}}
$$

onde o offset entre o receptor e a fonte é $x=x_{P}+x_{S}$, sendo $x_{P}$ e $x_{S}$ os offsets da onda $\mathrm{P}$ e da onda $\mathrm{S}$, respectivamente e $t_{P O}$ e $t_{S O}$ os tempos verticais de propagação das ondas $\mathrm{P}$ e $\mathrm{S}$, respetivamente. A equação de tempo de propagação para as ondas PP é composta por duas vezes o primeiro termo da Equação 3.4.

A resolução horizontal do método é definida pela zona de Fresnel (Figura 3.5), ou seja, a região de interferência construtiva da área de conversão ou de reflexão (Eaton et al., 1991). Para os campos da onda P (Equação 3.5) e P-SV (Equação 3.6) a zona de Fresnel pode ser definida como: 


$$
\begin{aligned}
& R_{F_{P}} \approx\left(\frac{\lambda z}{\gamma}\right)^{1 / 2} \\
& R_{F_{P-S V}} \approx\left(\frac{V_{P} V_{S} z k T}{V_{P} z+V_{S} k}\right)^{1 / 2}
\end{aligned}
$$

onde z é a espessura da camada, $\lambda$ é o comprimento da onda predominante, $\mathrm{k}$ é a distância do receptor até a base da camada (=z no caso de receptor colocado na superfície), $\mathrm{T}$ é o período predominante da onda, $V_{P}$ e $V_{S}$ são as velocidades das ondas $\mathrm{P}$ e $\mathrm{S}$, respectivamente $(\gamma=2$ ou $\gamma$ $=4$ por critério de Sheriff, 1980).

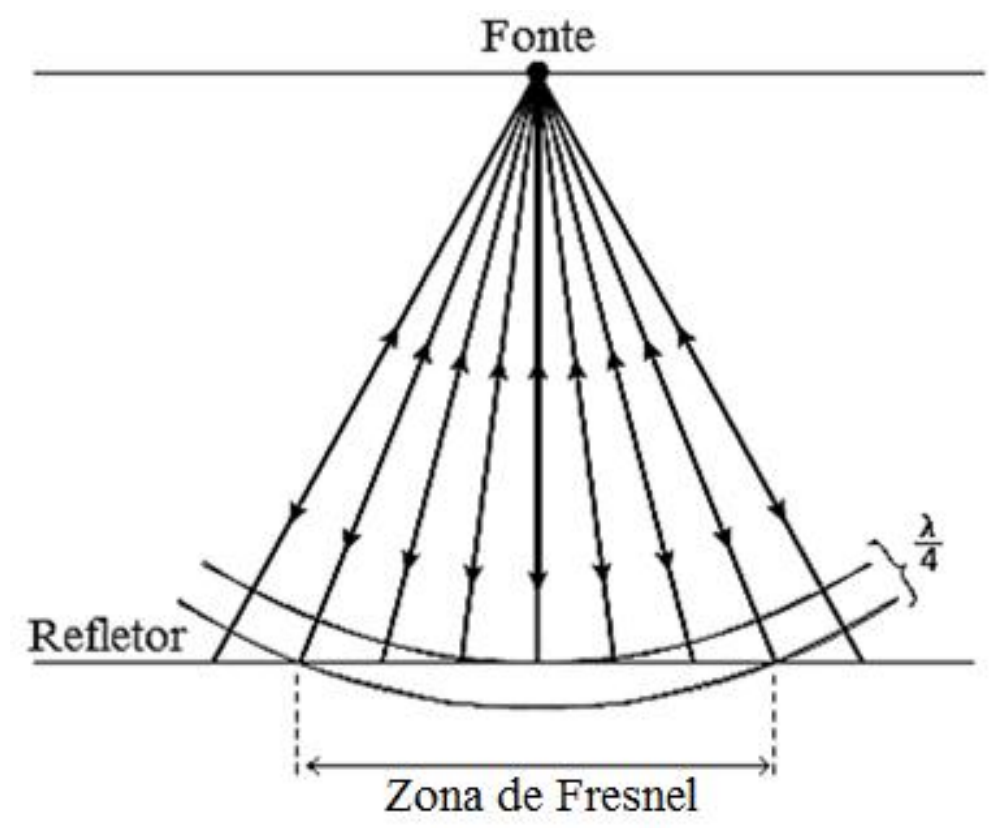

Figura 3.5: A região da interface refletora da qual a energia retorna como a metade do comprimento da ondícula é conhecida como zona de Fresnel.

A resolução vertical das ondas PP é próxima da razão $\lambda / 4$. Na proximidade ao ponto de conversão, os conteúdos em frequências dos eventos PP e PS registrados são semelhantes, o que sugere maior resolução vertical associada às ondas convertidas. Não obstante, para os eventos profundos, as ondas PS sofrem perda das maiores frequências maiores que a das ondas PP (Stewart et al., 2002).

Enquanto da refletividade, as ondas convertidas apresentam caraterísticas de convertibilidade de amplitude baixa nos offset pequenos (Stewart et al., 2002). As amplitudes das reflexões das ondas PP e das conversões das ondas PS podem ser estimadas a partir das equações de Zoeppritz. 
A partir das características do método descritas anteriormente, podemos listar as principais vantagens e desvantagens de sua aplicação. Entre as principais vantagens que oferece o registro do campo de onda mais completo podem ser mencionados:

a) obtenção de uma seção sísmica com características independentes (por exemplo: velocidades de empilhamento e múltiplas) (Stewart et al, 1999);

b) possibilidade de se obter os atributos combinados a partir de seções PP e PS, tais como: a razão Vp/Vs, a razão de Poisson, parâmetros petrofísicos de Lamé ( $\lambda \rho$ e $\mu \rho)$. Esses atributos podem ser usados para discriminar a litologia e prover um estimador sobre o fluido do poro (Hüseyin et al., 2010; Stewart et al, 1999; Stewart et al., 2003, Garotta et al., 2002; Gaiser, 1996);

c) iluminação de objetivos com baixa refletividade de ondas PP (Gaiser et al., 2001). Um dos efeitos da saturação dos poros dos meios geológicos por água/óleo é a redução do contraste entre as velocidades das ondas $\mathrm{P}$ entre diferentes litologias ou formações. As velocidades das ondas S refletem verdadeiras mudanças na litologia (Dasios et al, 1999);

d) melhora na resolução da imagem na parte rasa da seção sísmica. A resolução obtida com ondas PS no geral é melhor que a obtida com as ondas PP (Garotta et al., 2002; Gaiser et al., 2001; Dasios et al, 1999);

e) melhora do imageamento das falhas de alto ângulo (Stewart et al, 1999);

f) caracterização das rochas fraturadas, devido à birrefringência da onda $S$ em duas componentes, rápida e lenta (Gaiser et al., 2002).

Entre as desvantagens principais do emprego das ondas PS podem ser citados a amplitude baixa dos coeficientes de reflexão nos offsets pequenos e o caminho de propagação assimétrico (Gaiser, 1996). 


\section{Instrumentação}

Os equipamentos empregados na aquisição sísmica consistem principalmente de: fonte, sensores e unidade de registro. Uma das vantagens da aquisição das ondas convertidas tipo PSv é a possibilidade de usar as fontes verticais desenvolvidas e aperfeiçoadas para aquisição sísmica convencional (Haradage, 2017).

As fontes sísmicas terrestres podem ser classificadas como impulsivas ou vibratórias. A fonte impulsiva transfere ao subsolo um único impulso de alta energia, otimizando a eficiência de aquisição. Uma fonte vibratória transfere um sinal de baixa energia ao longo de um intervalo de tempo. As fontes vibratórias com um sinal programado (vibroseis) diminuem as distorções na assinatura da mesma, ou seja, diminuem a variação das amplitudes e fases com a posição de tiro (Tatham, 1991). Alguns exemplos das fontes sísmicas são mostrados na Figura 4.1.

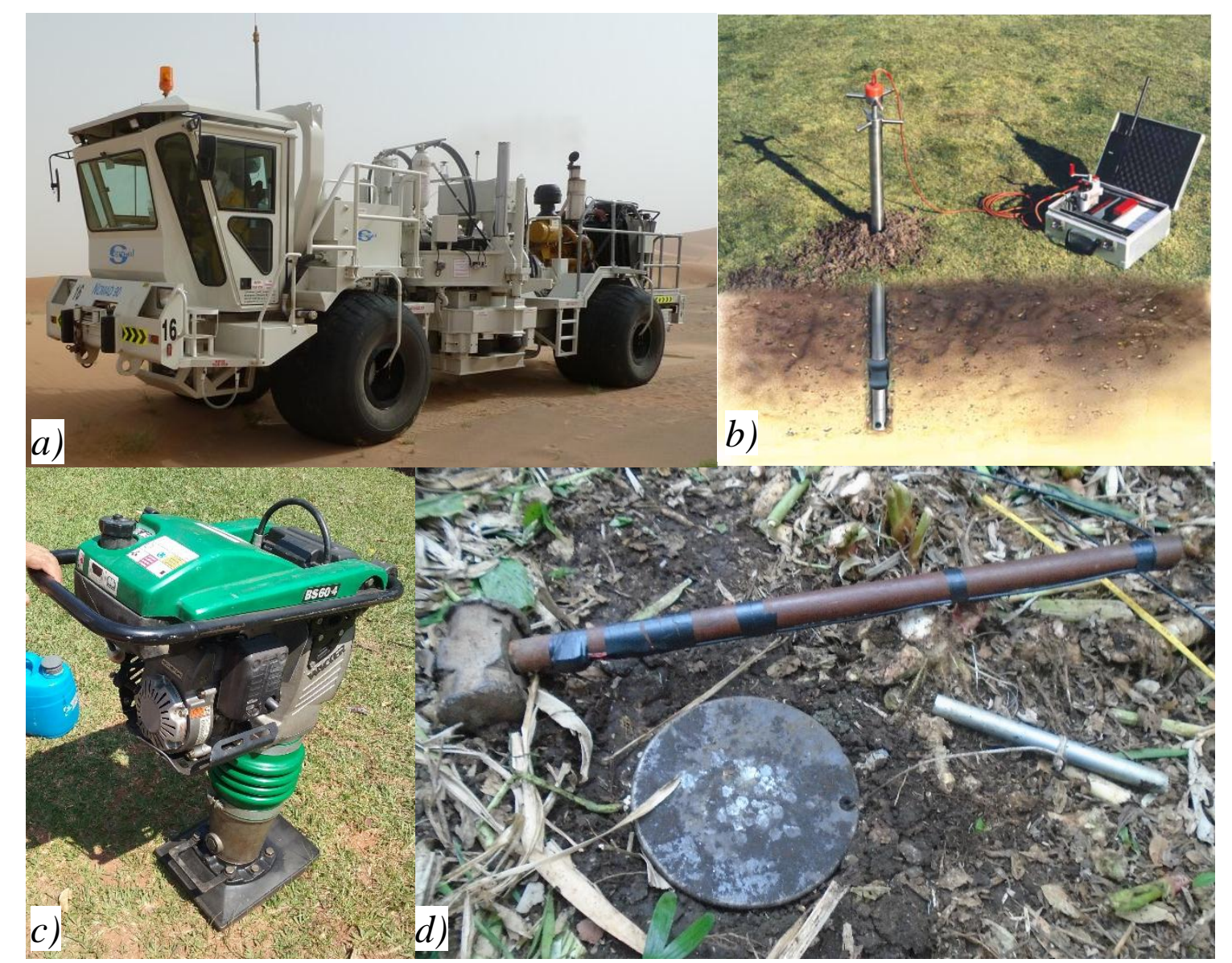

Figura 4.1: Fontes sísmicas a) Vibroseis Nomad 90 Neo da Sercel; b) Seismic Impulse Source System (SISSY) da Geosym; c) compactador de solo tipo 'Wacker'; d) marreta. 
A escolha da fonte é uma etapa importante em um projeto de sísmica de reflexão rasa. Existem diversos fatores que devem ser avaliados: energia, conteúdo de frequências, portabilidade, repetitividade, tempo entre os tiros consecutivos, dano ao meio ambiente, requerimentos de segurança, entre outros. Os fatores variam com a área de estudo (Miller et al., 1986).

Neste trabalho foram testadas duas fontes: compactador de solo tipo "wacker" (técnica mini-Sosie) e a marreta impactada sobre disco de ferro (Figura 4.1c e 4.1d). Tanto a marreta quanto o compactador são fontes do tipo impulsiva. No entanto, o método mini-Sosie considera a sequência de impactos do compactador como a "assinatura da fonte" a semelhança do sinal do vibroseis. $\mathrm{O}$ compactador gera uma sequência de impactos com frequência de $5 \mathrm{a}$ 15 vezes por segundo ao longo de um tempo determinado. Os impactos devem ser randomizados visando gerar séries pseudoaleatórias com fim de minimizar o ruído de correlação. A taxa média de impacto define a quantidade de ruído correlacionável, que é distribuído entre as amostras. Quanto maior o número das amostras, menor será a quantidade média de ruído correlacionável. As sequências com intervalos entre impactos maiores e mais aleatórias terão quantidades reduzidas de ruído correlacionável no registro. À medida que a sequência de impacto se torna menos aleatória, os eventos espúrios começam a aparecer nos dados interferindo com os eventos verdadeiros.

Entre os sensores sísmicos que medem a movimentação das partículas do solo podem ser distinguidos os eletromagnéticos, MEMS (sistema microeletromecânico) e os sensores óticos (Figuras 4.2, 4.3 e 4.4 respetivamente).

Os geofones eletromagnéticos (ou transdutores de velocidade) são empregados desde os anos 1930. O sensor é composto por uma bobina e uma massa conectada mediante uma mola a uma estrutura acoplada ao solo. Essa estrutura inclui um imã que gera um campo magnético na zona da bobina. A movimentação relativa entre o campo magnético e a bobina induz uma corrente elétrica proporcional à velocidade da movimentação (Figura 4.2a).

O MEMS (ou acelerômetros) foi introduzido na indústria sísmica no ano de 1999. Os sensores piezoeléctricos respondem às movimentações instantâneas do solo, ou seja, medem a aceleração das partículas. A saída digital desse sensor é proporcional à correção da força necessária para manter a massa estacionária quando o solo se encontra acelerado (Figura 4.3). 

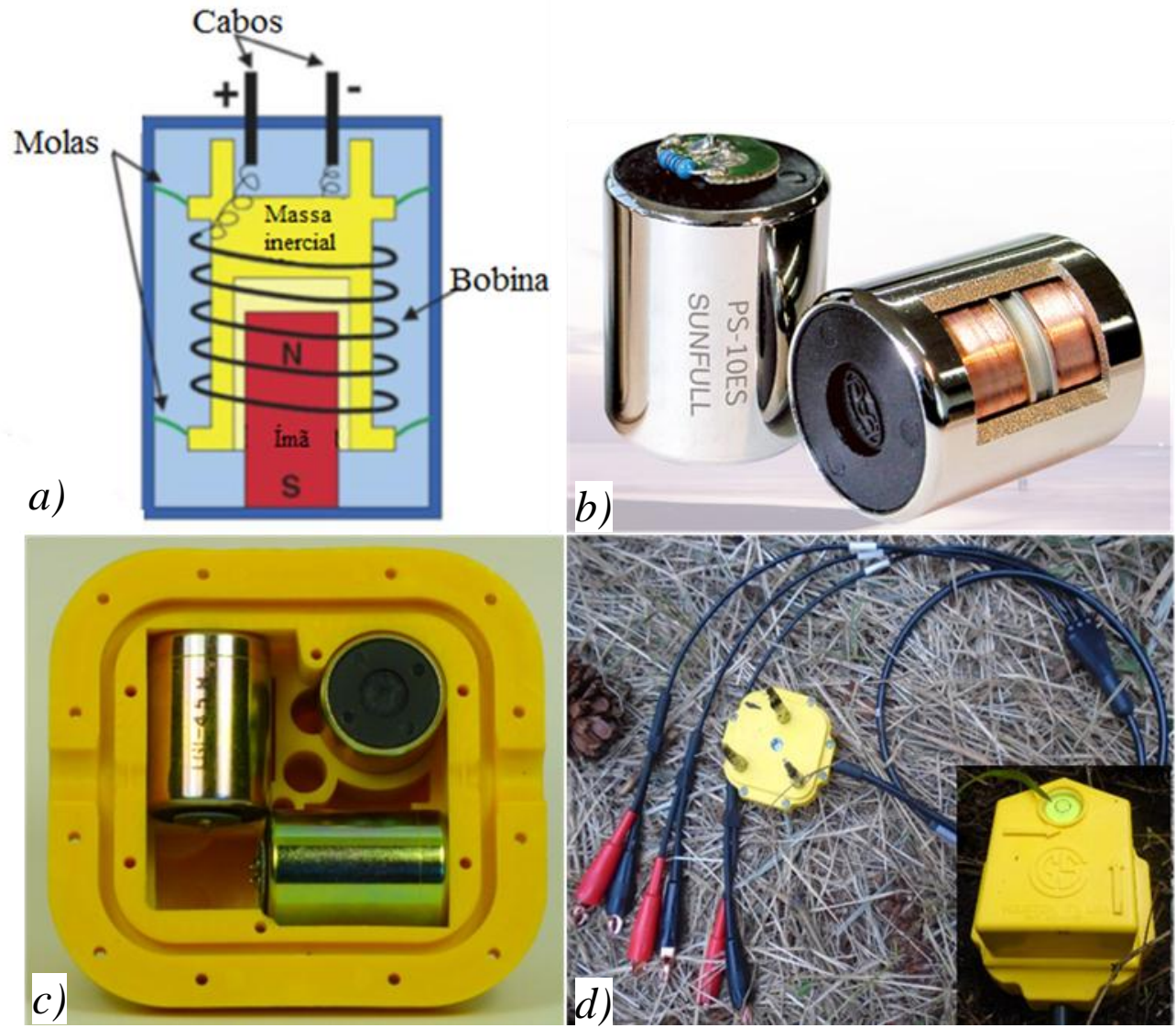

Figura 4.2: a) Princípio básico de funcionamento de sensor de velocidade. Fonte: Linear Collider Consortium (www.linearcollider.org); b) Sensor eletromagnético modelo OS-10ES produzido pela empresa Sunfull; c) Geofone 3C: sensores para registro das componentes vertical, radial $e$ transversal. Fonte: www.seismicnet.com; d) Geofone $3 C$ da Geometrics.
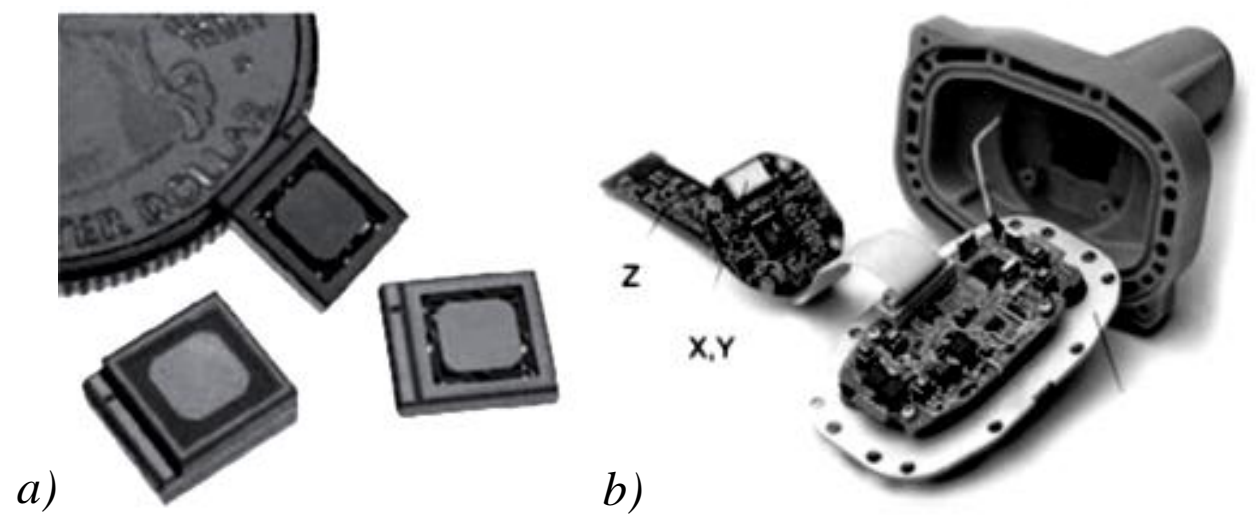

Figura 4.3: Componentes de Sistema microeletromecanico (MEMS): a) sensores de aceleração. Fonte: Meunier (2011); b) Acelerômetro triaxial de Sercel. Fonte: Hardage (2011)

O princípio dos sensores de fibra ótica está baseado na conexão entre a movimentação do solo e as mudanças no comprimento e largura da fibra. O sistema é composto por fibra ótica enrolada numa estrutura que consiste de dois semicilindros separados por um material flexível que muda de forma ao ser submetido a uma força (aceleração). A onda associada com 
sensor sensível a um comprimento de onda determinado é refletida antes e após viajar pela fibra ótica. A análise da diferença de fase entre essas duas reflexões resulta na medida da aceleração. A vantagem principal destes sensores é a insensibilidade à umidade e aos ruídos eletromagnéticos, e não requerem alimentação elétrica (Figura 4.4).

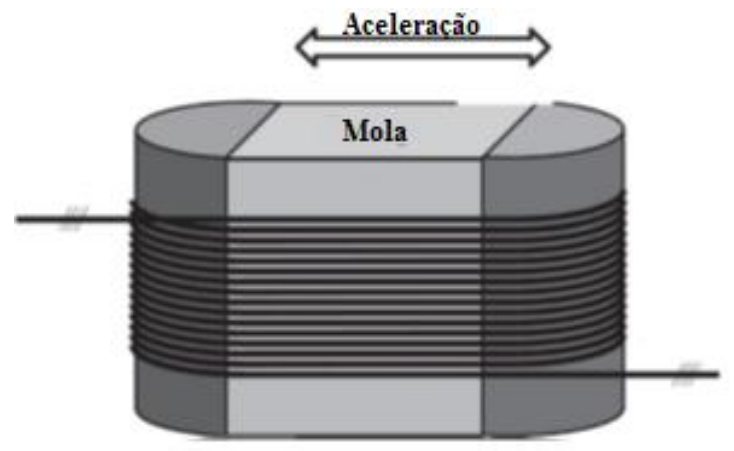

Figura 4.4: Acelerômetro ótico. A fibra ótica é enrolada entorno de uma estrutura, cujo tamanho muda na direção da força aplicada. A diferença de fase das duas reflexões (registro 1 e 2) provê a medida de aceleração. Fonte: Meunier (2011)

A diferença mais importante entre os geofones eletromagnéticos e os acelerômetros está nas suas respostas de ganho e de fase. A comparação entre as respostas de ganho e a fase de sensores tipo MEMS e geofones de $10 \mathrm{~Hz}$ da Sercel é mostrada na Figura 4.5. A resposta de amplitude e de fase do acelerômetro se mostra constante para todas as frequências, mas algumas vezes pode mostrar ruído não desejado e distorções abaixo de $10 \mathrm{~Hz}$.
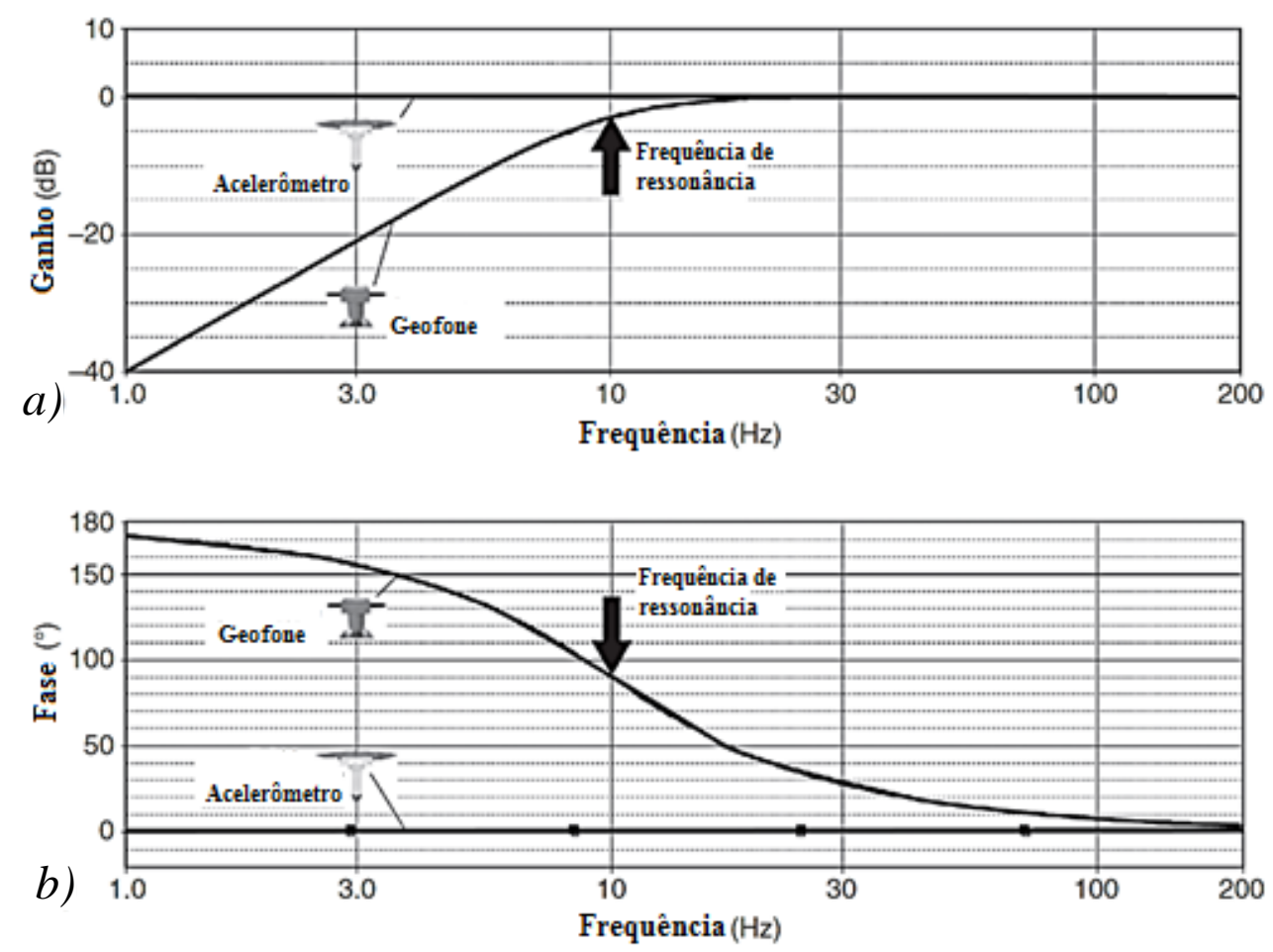

Figura 4.5: Comparação entre as respostas de a) ganho e b) fase de acelerômetro e geofone de $10 \mathrm{~Hz}$ da Sercel. Fonte: modificado de Hardage (2011) 
A diferença mais importante entre os geofones eletromagnéticos e os acelerômetros está nas suas respostas de ganho e de fase. A comparação entre as respostas de ganho e a fase de sensores tipo MEMS e geofones de $10 \mathrm{~Hz}$ da Sercel é mostrada na Figura 4.5. A resposta de amplitude e de fase do acelerômetro se mostra constante para todas as frequências, mas algumas vezes pode mostrar ruído não desejado e distorções abaixo de $10 \mathrm{~Hz}$.

Finalmente, uma vez emitido o sinal pela fonte sísmica ele é propagado através dos materiais do subsolo, refletido numa interfase e detectado pelos sensores colocados na superfície. A resposta dos sensores transmitida ao sismógrafo (Figura 4.6).

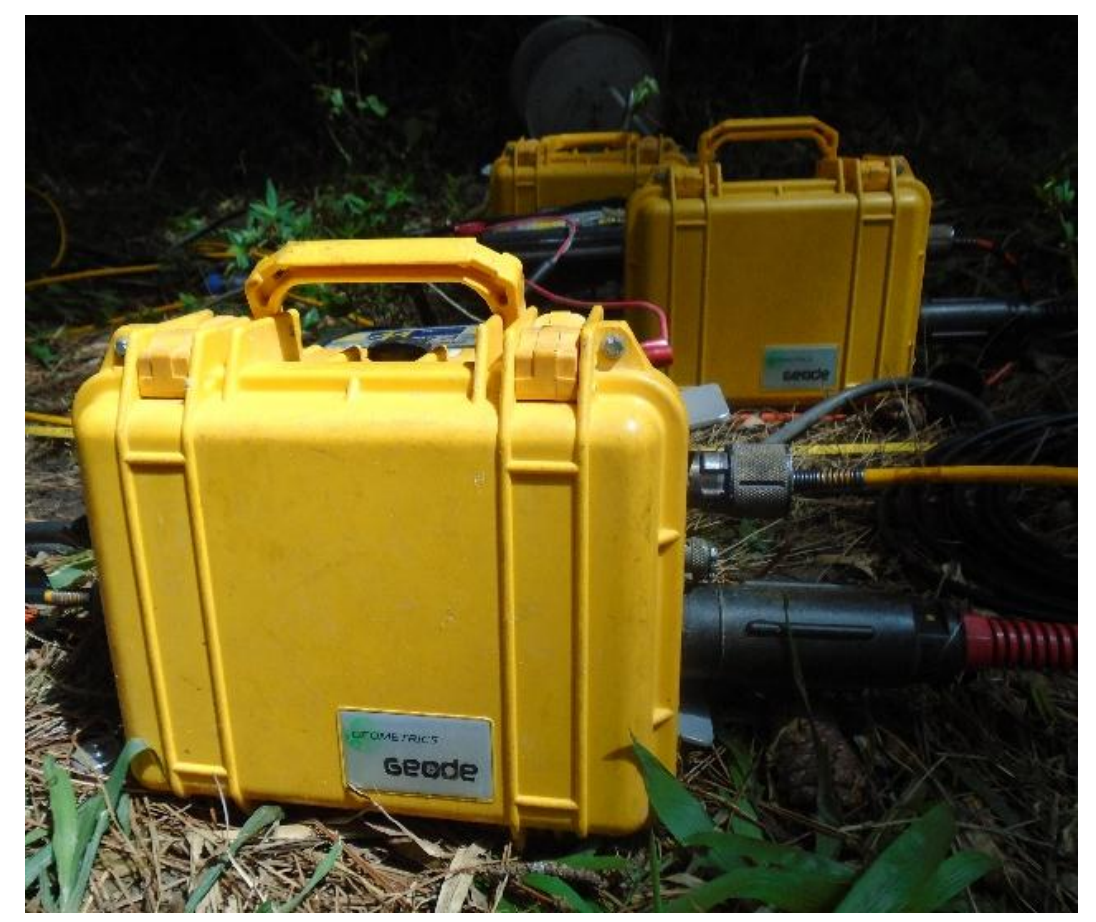

Figura 4.6: Sismógrafo Geode-Geometrics de 24 canais com conversor A/D de 24 Bits.

O sismógrafo é utilizado para o registro dos dados sísmicos e é operado por meio de software específico. Os sismógrafos atuais possuem conversor A/D de 24 bits e se diferenciam basicamente pela diferença no número de canais de registro.

Os dados podem ser armazenados nos formatos: SEG-Y, SEG-D ou SEG-2. 


\section{Parâmetros de aquisição}

O desenho da geometria e definição dos parâmetros de aquisição deve considerar as particularidades das ondas convertidas: velocidade baixa das ondas S e a assimetria do caminho do raio P-S (Figura 5.1), devido ao qual o ponto de conversão (asymptotic conversion point - ACP - ponto de conversão assintótico) se encontra deslocado para o receptor (Stewart et al., 2002). Os parâmetros que devem ser analisados são: amostragem, ângulo de migração, multiplicidade de traços e largura da banda de frequências (Meier, 2009).

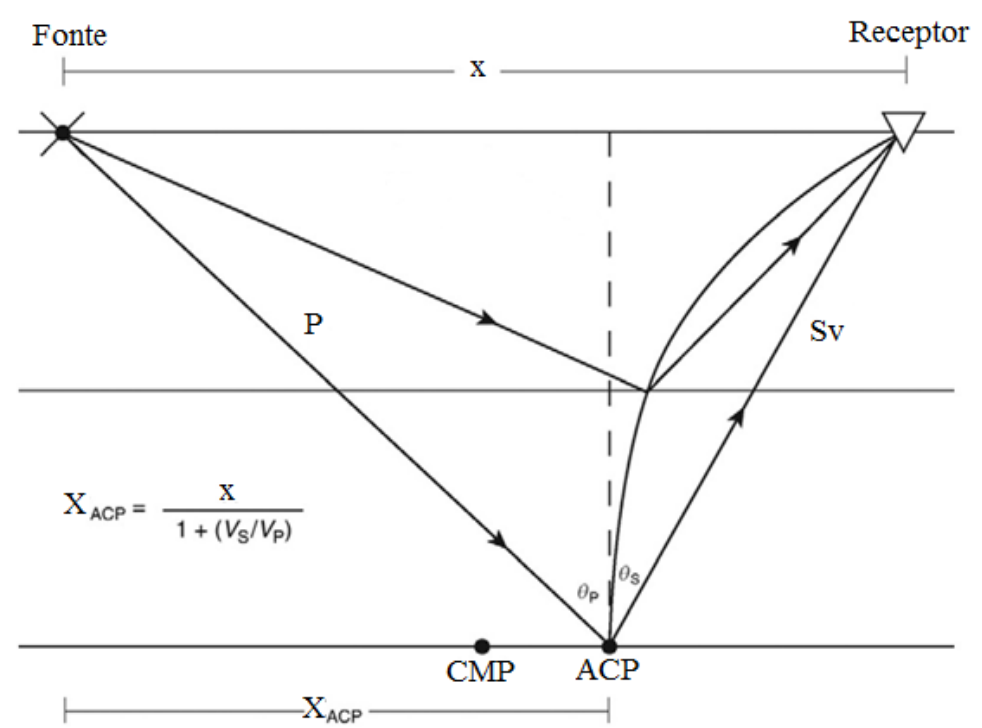

Figura 5.1: Caminho do raio P-S esquemático, onde se observa o deslocamento de ACP para o receptor. Fonte: Hardage et al. (2011).

A redução da banda de frequências causada por atenuação impacta negativamente a resolução. Existe um compromisso entre a baixa amplitude das ondas convertidas próximo ao offset zero e a atenuação que sofrem as ondas nos offset maiores.

Para corrigir as distorções presentes no registro sísmico se implementa o processo da migração sísmica, o qual posiciona os eventos nas suas verdadeiras posições espaciais e colapsa a energia das difrações até seus pontos de espalhamento. Como resultado, para se obter as imagens do alvo se deve analisar o ângulo de migração.

A frequência de amostragem necessária para o correto registro das ondas PS pode ser maior que a empregada para as ondas PP. Se consideramos que a amostragem temporal e o ângulo de migração empregados para a aquisição das ondas PP e PS são os mesmos, a seguinte equação é válida: 


$$
\frac{\Delta x^{P S}}{\Delta x^{P P}}=\frac{2}{\left[1+2 \gamma \cos \theta_{S}+\gamma^{2}\right]^{1 / 2}}
$$

Onde $\gamma=V_{P} / V_{S}, \theta_{S}$ é o ângulo de difração, $\Delta x^{P S}$ é a amostragem espacial das ondas PS, $\Delta x^{P P}$ é a amostragem espacial das ondas PP. A Equação 5.1 mostra que ao aumentar a resolução da imagem provida pelas ondas convertidas em relação à resolução das ondas PP, a amostragem espacial deve ser mais densa (Meier 2009).

Se entende por multiplicidade, a quantidade dos traços que iluminam o mesmo ponto de subsolo. Para o caso das ondas PP numa aquisição 2D pode ser calculada da seguinte forma:

$$
\text { Multiplicidade }_{2 D}=\frac{\text { Numero de traços }}{2} \times \frac{R_{i}}{S_{i}}
$$

onde Ri é o espaçamento entre os receptores e Si é o intervalo de distribuição da fonte. A multiplicidade das ondas convertidas tipo PS numa seção 2D sob certas condições é variável. Para evitar essa variação se recomenda usar intervalo espacial entre os tiros como múltiplo ímpar do espaçamento entre os receptores multiplicado pela razão $\mathrm{Vp} / \mathrm{Vs}$, ou seja, $\mathrm{Si} / \mathrm{Ri}=$ $\mathrm{nVp} / \mathrm{Vs}$, com n ímpar. Adicionalmente, podem ser incorporados no fluxo de processamento procedimentos para suavizar a variação da multiplicidade (Stewart et al., 1999).

Conclui-se, portanto, que para se determinar os parâmetros ideais de aquisição é desejável contar com dados de poços, tais como velocidades da onda $\mathrm{P}$ e onda $\mathrm{S}$. No caso de não se contar com os dados de poço é possível estimar alguns dos parâmetros a partir do ensaio de análise de ruído. 


\section{Processamento}

\subsection{Fluxo de processamento}

A seção sísmica PP é processada primeiramente e usada como referência para o processamento da seção das ondas convertidas. O fluxograma geral de processamento é apresentado na Figura 6.1.

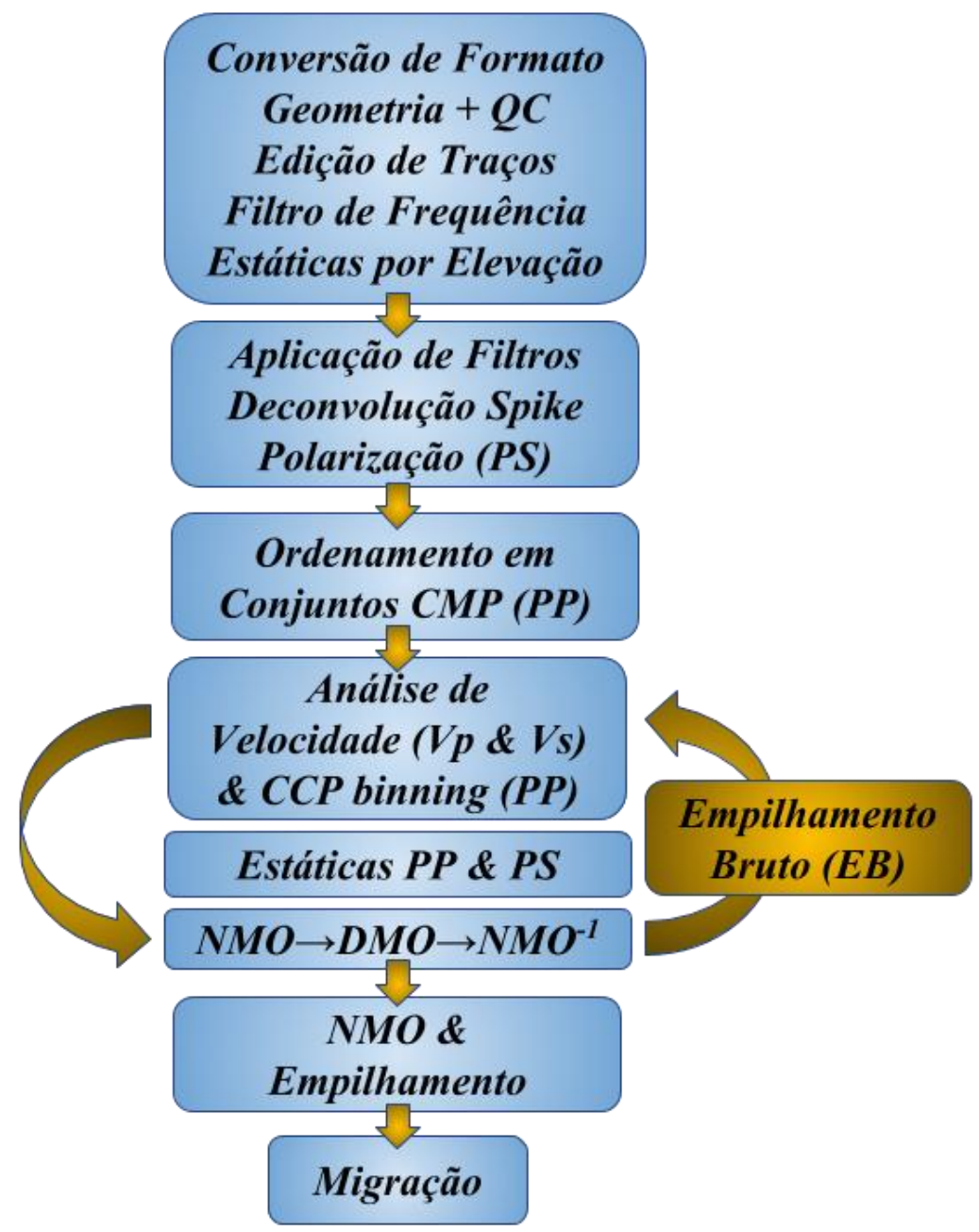

Figura 6.1: Fluxograma geral de processamento dos dados sísmicos 2D.

\subsection{Processamento das ondas PP}

O fluxo de processamento das ondas PP clássico é composto pelas etapas de préprocessamento (conversão de formato dos arquivos, aplicação da geometria de aquisição, 
edição dos traços, aplicação da correção estática), filtragem, deconvolução, ordenamento dos traços em conjuntos de ponto meio, análise de velocidade, estática residual, correção NMO/DMO, empilhamento e migração.

\subsubsection{Conversão de formato}

Este passo é necessário se os dados adquiridos não têm o formato requerido pelo software de processamento.

\subsubsection{Edição de traços}

Os traços muito ruidosos e monofásicos são zerados e os de polaridade invertida corrigidos.

\subsubsection{Filtro de frequência}

Um ruído com frequência dominante diferente da banda de frequências das reflexões pode ser eliminado/atenuado mediante aplicação de filtro (passa-baixas, passa-altas, passabanda). $\mathrm{O}$ filtro de frequências pode ser implementado em mais de uma etapa da sequência de processamento: na fase inicial para reduzir os ruídos mais evidentes, posteriormente para remover os artefatos produzidos por outros passos de processamento, e finalmente para gerar uma seção otimizada para visualização do intérprete.

\subsubsection{Geometria}

A inscrição da geometria deve ser feita anteriormente à correção por ganho dependente do offset. Consiste na inscrição das coordenadas dos receptores e dos tiros nos cabeçalhos dos traços sísmicos. Se as componentes não foram gravadas em conjuntos separados, pode ser conveniente, primeiramente, separar os traços de mesma componente (vertical e as horizontais). 


\subsubsection{Correção estática}

Se a topografia mostra variação na elevação, as estáticas por elevação devem ser aplicadas para reduzir os tempos de propagação a um datum comum. Se a variação topográfica é pequena, o datum pode ser um plano. Para o caso da topografia abrupta é necessário o uso de datum variável ao longo da linha sísmica.

Os tempos de reflexão são afetados pelas irregularidades da camada superficial de rocha alterada, chamada weathering. A estimativa dessas correções estáticas geralmente é feita a partir das refracções associadas à base dessa camada superficial.

\subsubsection{Ganho}

As amplitudes devem ser corrigidas devido à divergência esférica que depende do tempo de propagação e à perda de energia por atenuação.

\subsubsection{Processamentos relacionados à minimização dos ruídos sísmicos}

Os dados sísmicos sofrem interferências de diferentes tipos de ruídos, os quais podem ser classificados em dois grandes grupos: ruídos coerentes (gerados pela fonte sísmica empregada) e ruídos não coerentes (ou ruído branco, gerados por fontes externas). Todos os ruídos não podem ser totalmente eliminados, mas a relação sinal-ruído pode ser melhorada mediante diversas técnicas.

Se bem na aquisição das ondas PP normalmente é empregado o arranjo de sensores para diminuir diversos tipos de ruídos, quando é realizada a aquisição de sísmica multicomponente o arranjo de sensores pode atuar como filtro nas componentes horizontais, prejudicando o dado de interesse (Hoffe et al., 2002).

O ruído branco pode ser reduzido mediante o empilhamento ou filtragem.

Os ruídos coerentes mais comuns na aquisição sísmica terrestre são: ground-roll e a onda aérea. O ground-roll é um ruído principalmente dominado pelas ondas Rayleigh. É caracterizado por alta amplitude, baixa frequência $(<20 \mathrm{~Hz})$ e baixa velocidade de fase $(<1000$ $\mathrm{m} / \mathrm{s}$ ). Entre as técnicas de remoção/atenuação do ground-roll destacam-se o empilhamento, zerado de zonas afetadas, filtro f-k, filtro de frequências.

As reflexões múltiplas são consideradas ruído coerente caso as reflexões primárias sejam o alvo de estudo. Entre as técnicas de filtragem estão as baseadas na velocidade 
(discriminação por NMO), periocidade das múltiplas (deconvolução), assim como extração das reflexões múltiplas mediante a modelagem.

\subsubsection{Deconvolução (filtro inverso)}

Os filtros inversos são desenhados para remover os efeitos adversos produzidos pela propagação do pulso sísmico no meio geológico. Esses efeitos modificam o pulso sísmico, gerando trens de ondas múltiplas ou absorvendo progressivamente as frequências altas. Entre os filtros inversos mais usados estão a deconvolução do pulso sísmico (spiking) e a deconvolução preditiva. A deconvolução do tipo spiking pré-empilhamento visa melhorar a resolução temporal através da compressão do pulso sísmico a um spike. Nesta etapa, tanto o ruído como o sinal são ampliados motivo pelo qual a filtragem passa-banda pode ser requerida.

\subsubsection{Filtro de velocidade ou filtro F-K}

A velocidade com que uma frente de onda aparenta se propagar na superfície ao longo de um arranjo de geofones é chamada de velocidade aparente $V_{a}$, onde $V_{a}=V / \sin \alpha$ e sua frequência igual a $f=V_{a} k_{a}$, onde $k_{a}$ é o número de onda aparente (Figura 6.2.9.1).

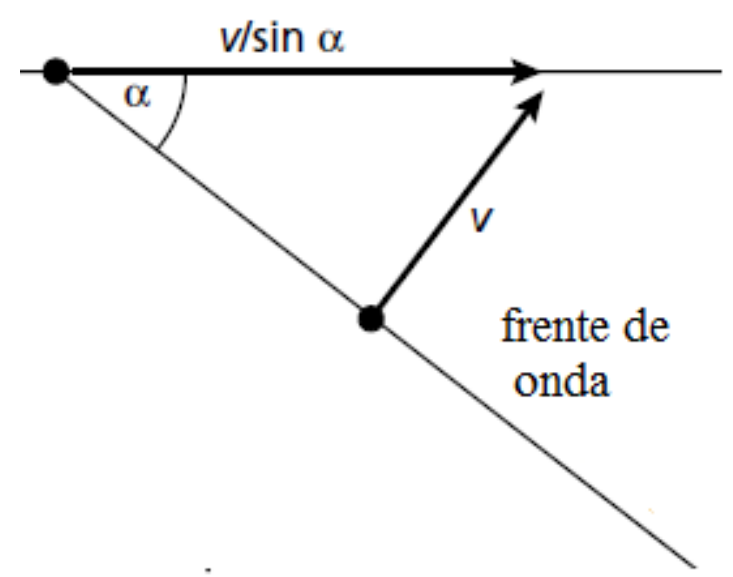

Figura 6.2.9.1: A onda que propaga-se em angulo a com a horizontal ao longo de arranjo de detectores com a velocidade aparente $V_{a}=V / \sin \alpha$ Fonte: Kearey et al (2002).

O gráfico de frequência versus número de onda aparente $\left(k_{a}\right)$ para um evento produz uma linha reta cujo gradiente é a velocidade aparente. Devido ao fato de que todo evento sísmico é caracterizado por uma curva f-k com inclinação determinada, é possível remover o 
ruído coerente dos dados sísmicos com base na velocidade aparente (Figura 6.2.9.2). Este tipo de filtro é chamado de filtro de velocidade ou filtro F-K.

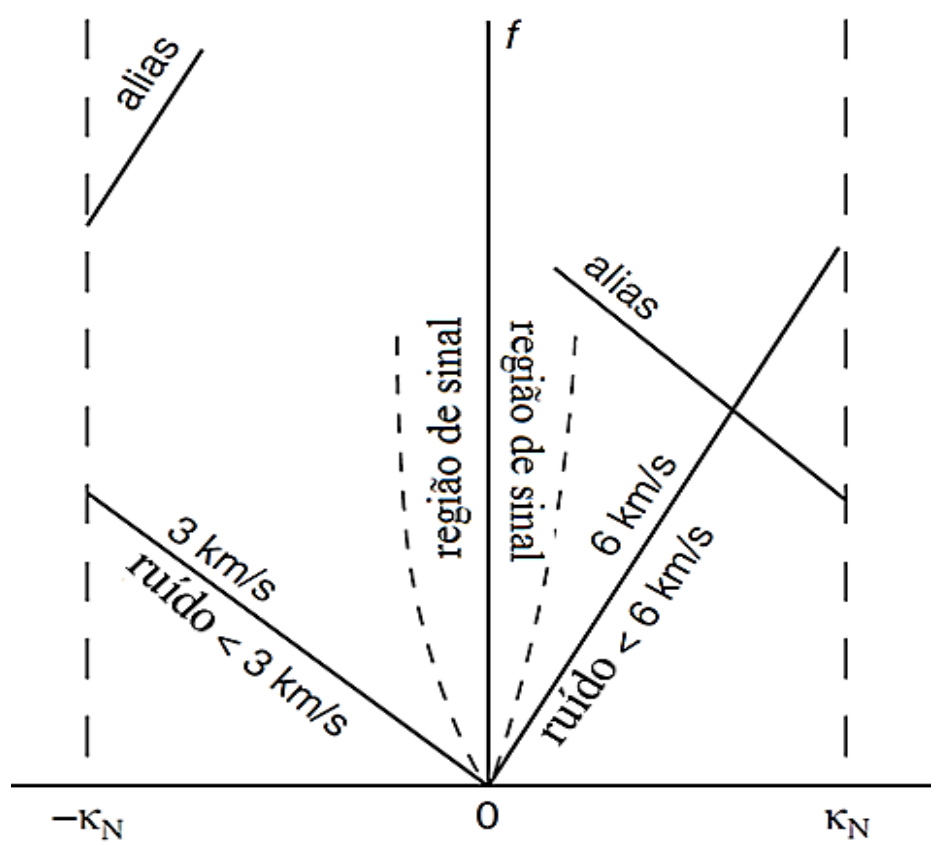

Figura 6.2.9.2: Distribuição de sinal e ruído em um gráfico no domínio f-k, onde Kn é o numero de onda de Nyquist. Fonte: modificada de Geldart e Sheriff (2004).

A filtragem F-K envolve a aplicação da transformada 2D de Fourier (do domínio t-x ao domínio f-k), remoção das zonas que contêm os eventos de ruído e posterior aplicação da transformada inversa para retornar os dados filtrados ao domínio t-x.

\subsubsection{Filtro de coerência}

A separação de sinal e ruído pode ser baseada na coerência lateral dos eventos geológicos e sua previsibilidade em base estatística. Pelo teorema central de limite um sinal é nãogaussiano. Usando uma transformada linear é possível focar o sinal, aumentando a independência estatística das amostras, melhorando sua propriedade não-gaussiana e procedendo com a separação de sinal e ruído (Harlan, 1984).

\subsubsection{Ordenamento por conjuntos CMP}

A aquisição sísmica multicanal é realizada em coordenadas tiro-receptor, mas o processamento é feito majoritariamente no domínio de ponto médio comum (CMP), a partir da definição da geometria de aquisição. 


\subsubsection{Análise de velocidade}

A análise de velocidade é realizada sobre os conjuntos CMP. Existem diversas técnicas para analisar as velocidades de propagação, entre as quais estão: espectro de velocidades ou análise semblance, painel de seções de empilhamento com velocidade constante e painel NMO através da análise da "horizontalização" das hipérboles de reflexão dos conjuntos CMP. No caso dos conjuntos CCP das componentes horizontais, a forma adequada para a análise de velocidade é a horizontalização dos eventos. A análise de velocidade permite a obtenção de uma tabela de velocidades versus tempo duplo de propagação (TWT).

\subsubsection{Correção do sobretempo normal (NMO - Normal-Moveout)}

A correção do sobretempo normal (NMO-Normal-Moveout) também é chamada da correção dinâmica e é variável em função do tempo de reflexão.

A correção NMO, é realizada usando o campo das velocidades. Se os tempos das reflexões em conjuntos CMP descrevem uma função aproximadamente hiperbólica, o processo de NMO remove o sobretempo em função do offset, "horizontalizando" os eventos. Uma das consequências de aplicação desse processo é o estiramento dos traços (efeito stretch), mais significativo nos traços relativos aos offset maiores e para os tempos menores. Com o objetivo de preservar a resolução do dado é preciso realizar o silenciamento (muting) das partes dos traços sísmicos cujo estiramento for superior ao determinado pelo processador.

A correção NMO válida para um modelo de terra estratificado, homogêneo e isótropo pode ser realizada mediante à equação hiperbólica:

$$
t_{P}=\sqrt{t_{P O}^{2}+\frac{x^{2}}{V_{P N}^{2}}}
$$

parametrizada pelo tempo da propagação vertical $t_{P O}$, offset $x$, e velocidade $\mathrm{NMO}\left(V_{P N}\right)$. Como velocidade NMO entende-se a velocidade que permite a "horizontalização" dos eventos. 


\subsubsection{Correção do sobretempo de mergulho (DMO - Dip-Moveout)}

A dispersão dos pontos de reflexão devido ao mergulho da interface causa aumento da velocidade aparente necessária para "horizontalizar" os eventos. Para evitar esse problema, se aplica a correção dip moveout (DMO) para colocar as reflexões nas posições corretas antes de realizar a análise de velocidade (Schafer, 1992).

\subsubsection{Empilhamento}

Se a velocidade de correção NMO for adequada, o empilhamento dos conjuntos de traços CMP melhora a relação sinal ruído do dado. Se a velocidade NMO não é próxima da verdadeira, a hipérbole fica subcorrigida ou sobrecorrigida diminuindo a qualidade da seção empilhada (Figura 6.2.15.1).

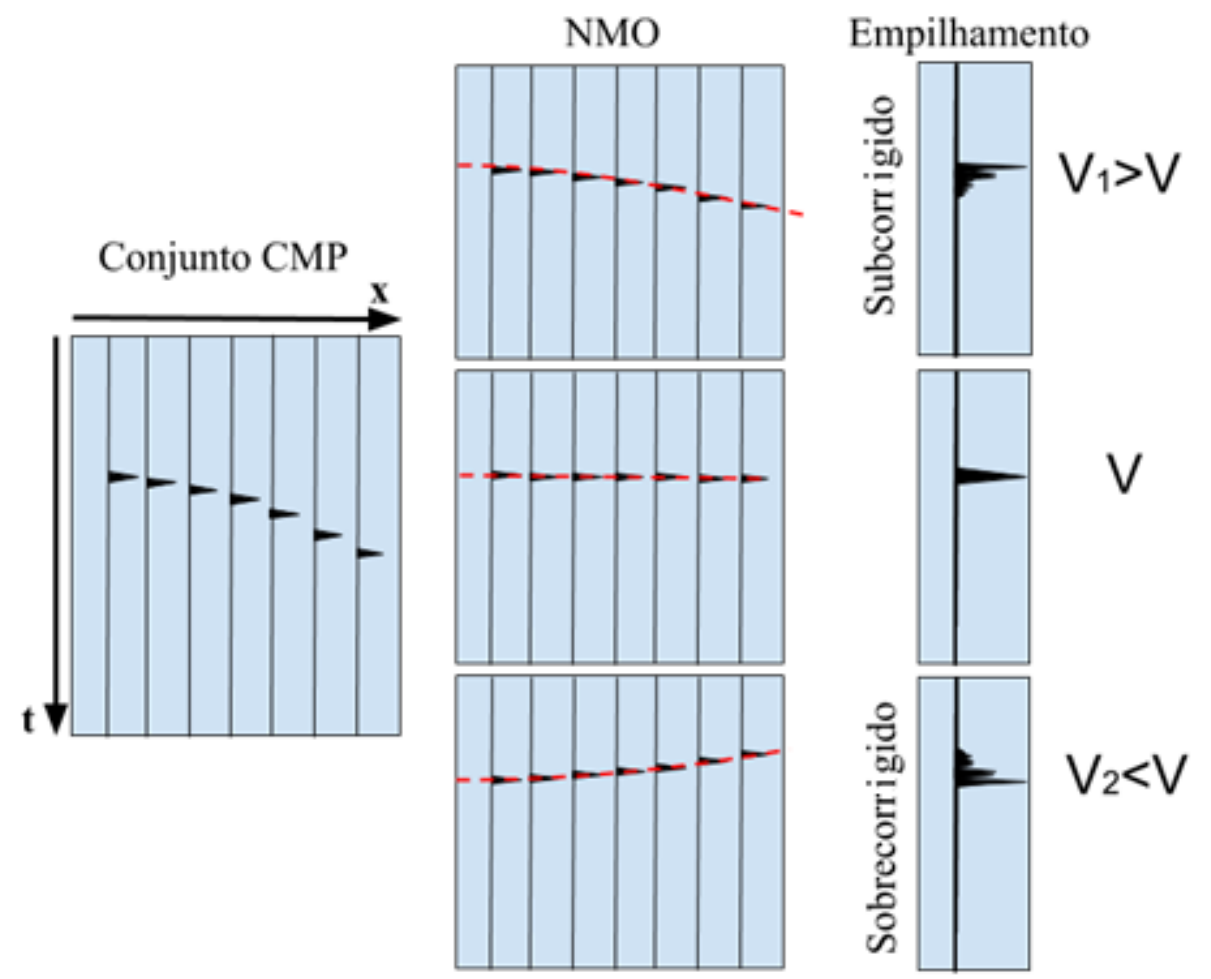

Figura 6.2.15.1: Empilhamento dos traços de um conjunto CMP: a) conjunto CMP sem correção NMO; b) conjunto subcorrigido c) conjunto corrigido d) conjunto sobrecorrigido.

\subsubsection{Migração}

Qualquer operação de migração busca a recuperação das relações geométricas verdadeiras dos eventos de reflexão. 
Geometricamente, dado um tempo de reflexão, o ponto de reflexão pode ser posicionado em qualquer ponto sobre um semicírculo centrado no CMP. Numa seção empilhada não migrada o ponto é mapeado diretamente abaixo do CMP considerado.

Considerando a situação de velocidade constante (Figura 6.2.16.1), a reflexão no ponto D de um refletor com mergulho $\alpha_{V}$ e observado em ponto B é plotado em D'. A seguinte relação, chamada equação de migração, representa a relação geométrica:

$$
\tan \left(a_{O}\right)=\sin \left(a_{V}\right)
$$

onde $\alpha_{O}$ é a inclinação aparente observada na seção sem migrar. Sendo que o mergulho real da interface geológica $\left(\alpha_{V}\right)$ é maior que $\alpha_{O}$.

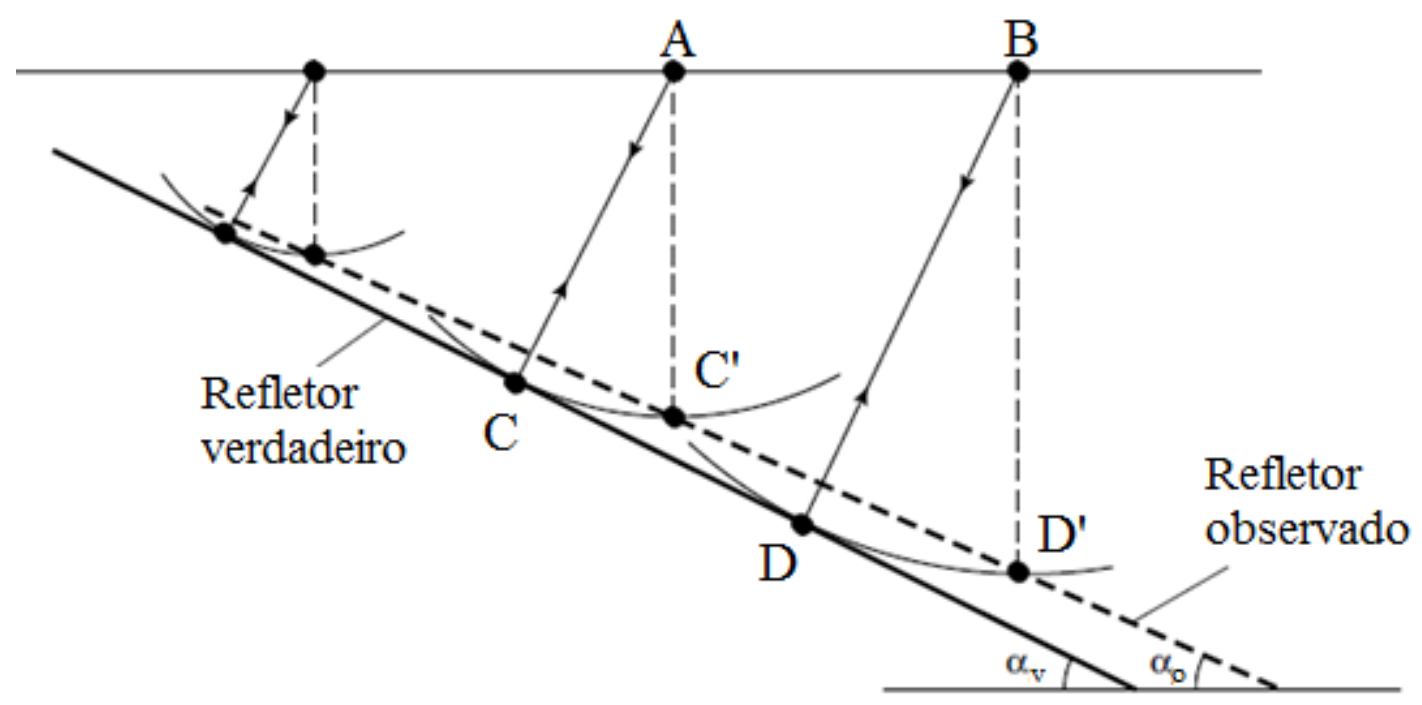

Figura 6.2.16.1: Imagem da interface na posição espacial verdadeira. Fonte: modificada de Kearey et al (2002).

A migração sísmica normalmente é feita sobre os dados empilhados para reduzir a quantidade de traços a ser migrados a um fator equivalente a multiplicidade do levantamento, diminuindo assim os custos computacionais associados. A migração dos dados empilhados está baseada nas hipóteses de que o empilhamento reconstrói com boa fidelidade a forma do traço zero-offset. Esta suposição não será válida no caso de registros em áreas de alta complexidade estrutural e/ou variação lateral de velocidade (Kearey et al., 2002). Nesses casos, deve ser analisada a necessidade de realizar migração pré-empilhamento em tempo ou 
migração em profundidade pré ou pós-empilhamento. A Figura 6.2.16.2 mostra os tipos de migração que podem ser realizadas de acordo com a complexidade da área.

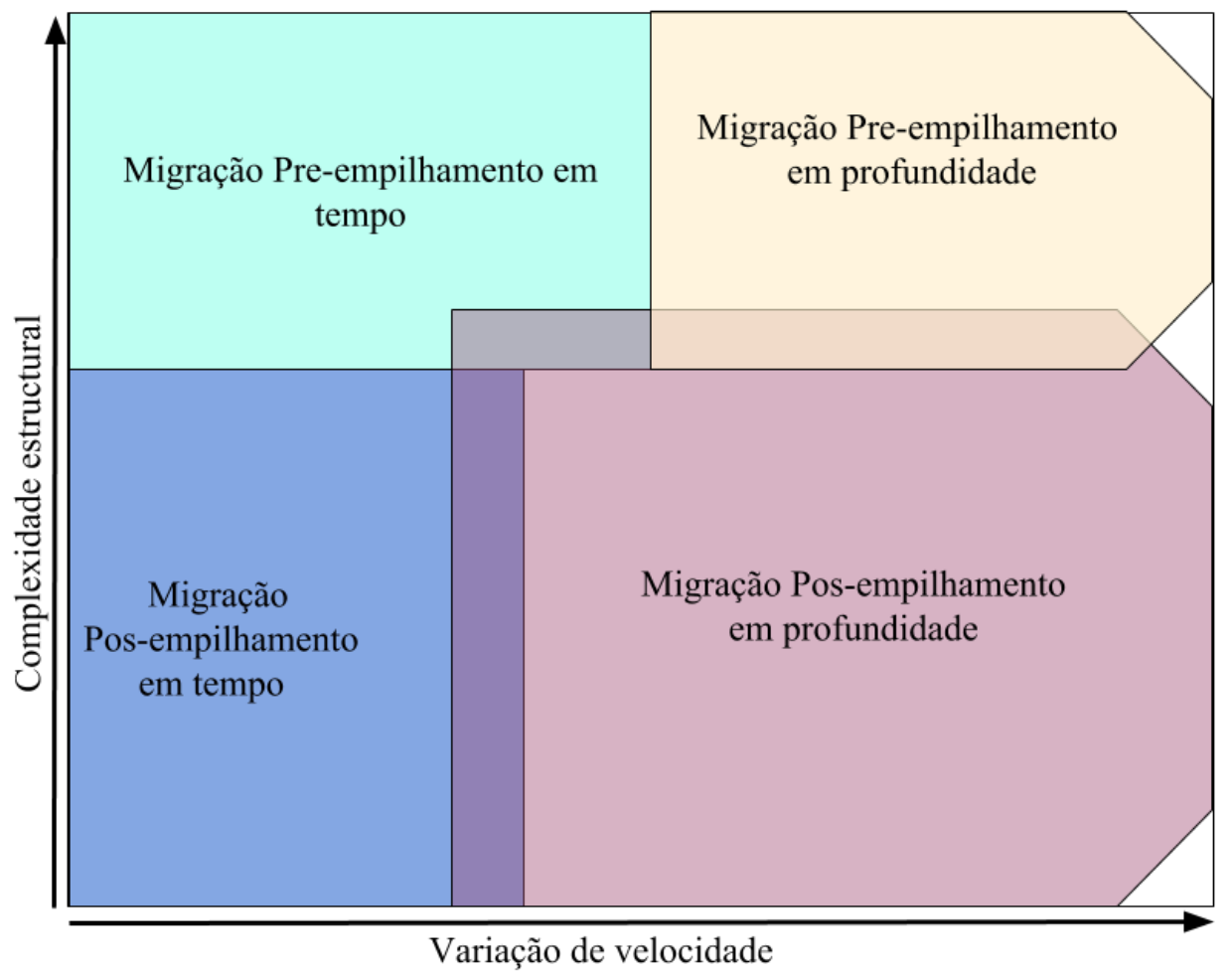

Figura 6.2.16.2: Tipos de migração dependendo da complexidade estrutural e variação de velocidade do subsolo.

A velocidade de migração é determinante para se obter uma seção corretamente migrada. Se a velocidade usada for menor que a verdadeira a seção vai ficar submigrada, e se a velocidade de migração for maior a seção vai ficar sobremigrada.

\subsection{Processamento das ondas PS}

O fluxo de processamento dos dados com registros dos eventos PS contém as etapas discutidas para o caso das ondas PP, modificando e agregando alguns passos para levar em conta as particularidades das ondas PS. Alguns dos passos são: análise da razão Vp/Vs, ordenamento em conjuntos de pontos de conversão comum e correções estáticas para ondas S.

\subsubsection{Conversão de polaridade}

A polaridade do sinal depende da orientação do receptor e fonte. Para o caso dos dados 2D os registros das componentes horizontais apresentam polaridade oposta de cada lado de 
fonte. Neste caso resulta suficiente mudar a polaridade de um dos lados antes de realizar o binning (Bland e Stewart, 1996).

\subsubsection{Correções estáticas}

A primeira aproximação das correções estáticas é extraída do processamento das ondas PP. Uma vez aplicadas é possível realizar uma rotina automatizada de estáticas residuais relacionadas aos receptores.

\subsubsection{Recuperação da amplitude}

A recuperação de amplitude deve ser aplicada de forma idêntica nas duas componentes horizontais.

\subsubsection{Ordenamento por conjuntos ACCP}

Um dos passos mais importantes no processamento das ondas convertidas é o "encelamento" dos traços sísmicos, mais conhecido como binning, já que o mesmo condiciona o resultado final.

Existem diferentes aproximações para calcular os pontos de conversão comum. Uma das mais simples é a aproximação assintótica (Asymptotic Common Conversion Point - ACCP binning). Assumindo que o ângulo de incidência é pequeno, seguinte relação pode ser usada para calcular a posição do ponto de conversão:

$$
X_{S} \approx X \frac{1}{\left(1+V_{P} / V_{S}\right)}
$$

onde $X_{S}$ é o ponto de conversão e X é o offset entre o receptor e a fonte. A variação de posição de ponto de conversão fica dependendo da variação da razão $\mathrm{Vp} / \mathrm{Vs}$ e o offset entre o receptor e a fonte (Garotta, 2000). Observe que para Vp/Vs constante a Equação 6.3.4 transforma-se em $X_{S} \approx X G$, onde $G=\frac{1}{\left(1+\mathrm{V}_{\mathrm{S}} / V_{P}\right)}$ é uma constante para $\mathrm{Vp} / \mathrm{Vs}$ constante. Desta forma, no caso de $\mathrm{Vp} / \mathrm{Vs}$ constante, a posição do ponto de conversão fica dependente unicamente do offset. 
Realizando o empilhamento no ACCP pode ser observada a variação de fold e a influência do mesmo no deterioro da imagem. Para diminuir esse efeito negativo, é possível calcular a média dos traços adjacentes ou realizar DMO (Stewart et al., 1999).

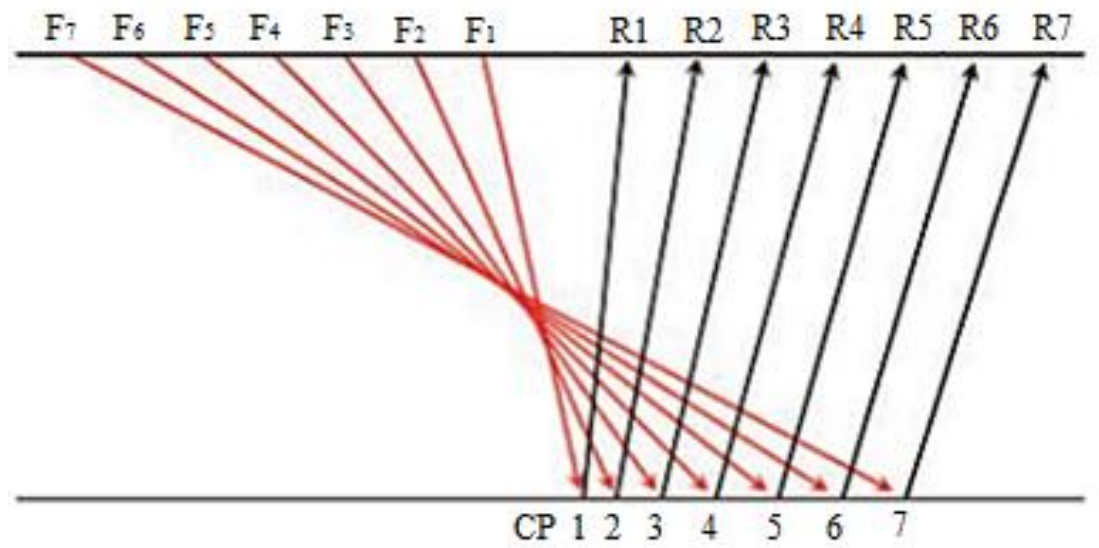

Figura 6.3.4.1: Ilustração de raios das ondas PS, onde CP são os pontos de conversão.

\subsubsection{Deconvolução}

O operador de deconvolução deve ser definido a partir das duas componentes horizontais e aplicado da mesma forma. O comprimento de operador para a seção das ondas PS e definido a partir de razão $\mathrm{Vp} / \mathrm{Vs}$. Se a resolução das ondas PS é melhor que a das PP é sugerido não vincular os operadores de deconvolução aplicados para a componente vertical e as componentes horizontais.

\subsubsection{Correção NMO}

A velocidade de NMO e os algoritmos convencionais podem ser aplicados às ondas convertidas, mas não ajustam perfeitamente. A função hiperbólica das ondas convertidas que aproxima os tempos de propagação para offset zero é:

$$
t_{C}=\sqrt{t_{C O}^{2}+\frac{x^{2}}{V_{C N}^{2}}}
$$

Onde $t_{C O}=\left(t_{P O}+t_{S O}\right) / 2$ é o tempo duplo de propagação (TWT) vertical e $V_{C N}$ é a velocidade NMO das ondas convertidas. Quando os dados são corrigidos com a Equação 6.3.6, o ajuste é bom para offset curtos, mas o erro vai crescendo com offset (Gaiser, 2016). 


\subsection{Pós-processamento}

A etapa de pós-processamento depende do objetivo. Se o objetivo é pesquisar a litologia a partir da razão Vp/Vs, o pós-processamento consiste em correlacionar os modos P e PS para derivar a razão de tempos de propagação, ou seja, Vp/Vs e cálculo do módulo de Poisson.

Segundo Bokhonok (2011), a estimativa da razão Vp/Vs usando o tempo normal apresenta menor erro relativo e pode ser calculada usando a equação proposta por Stewart et al. (1999):

$$
\frac{V_{P}}{V_{S}}=\frac{2 t_{P S}}{t_{P P}}-1
$$

A partir da razão Vp/Vs e possível estimar a razão de Poisson usando a seguinte equação:

$$
\sigma=\frac{\frac{1}{2}\left(\frac{\mathrm{V}_{\mathrm{P}}}{\mathrm{V}_{\mathrm{S}}}\right)^{2}-1}{\left(\frac{\mathrm{V}_{\mathrm{P}}}{\mathrm{V}_{\mathrm{S}}}\right)^{2}-1}
$$




\section{Aquisição}

\subsection{Análise de ruído}

Visando determinação dos parâmetros de aquisição foram realizados ensaios de ruído na área de Colônia e no campus da USP. As provas foram realizadas usando como fontes a marreta e o compactador, e como sensores, 48 geofones triaxiais de $10 \mathrm{~Hz}$ de frequência natural e com resposta linear até $250 \mathrm{~Hz}$. Os tiros foram realizados nos offsets de 1 metro, 49 metros e 98 metros. Na área de Colônia foi realizado um tiro adicional com a marreta aos 147 metros (Figura 7.1.1 b). O espaçamento entre os geofones usado foi de 1 metro. A configuração dos cabos usada se mostra na Figura 7.1.1a. Essa configuração oferece a vantagem de observar as três componentes separadas no momento de aquisição.

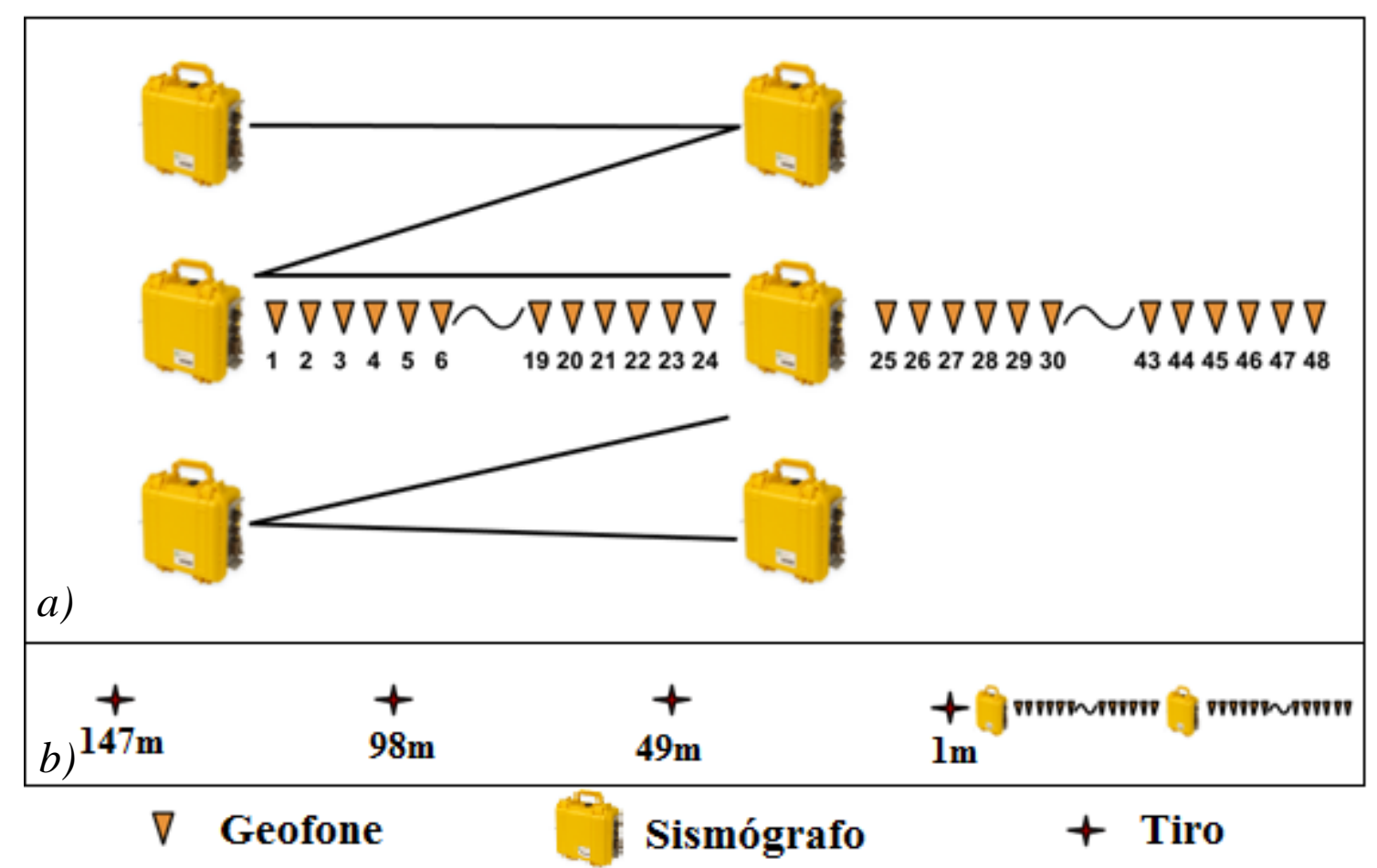

Figura 7.1.1: a) Configuração dos cabos na aquisição para o análise de ruído; b) disposição e offsets dos tiros realizados.

Nas Figuras 7.1.2 e 7.1.3 se mostram os registros obtidos com o emprego do compactador e da marreta, respectivamente, na área de Colônia. A componente vertical (Figuras 7.1.2a e 7.1.3a) apresenta a energia das ondas tipo PP. Se comparamos o registro obtido com o compactador (Figura 7.1.4) e o registro obtido com a marreta (Figura 7.1.5) é 

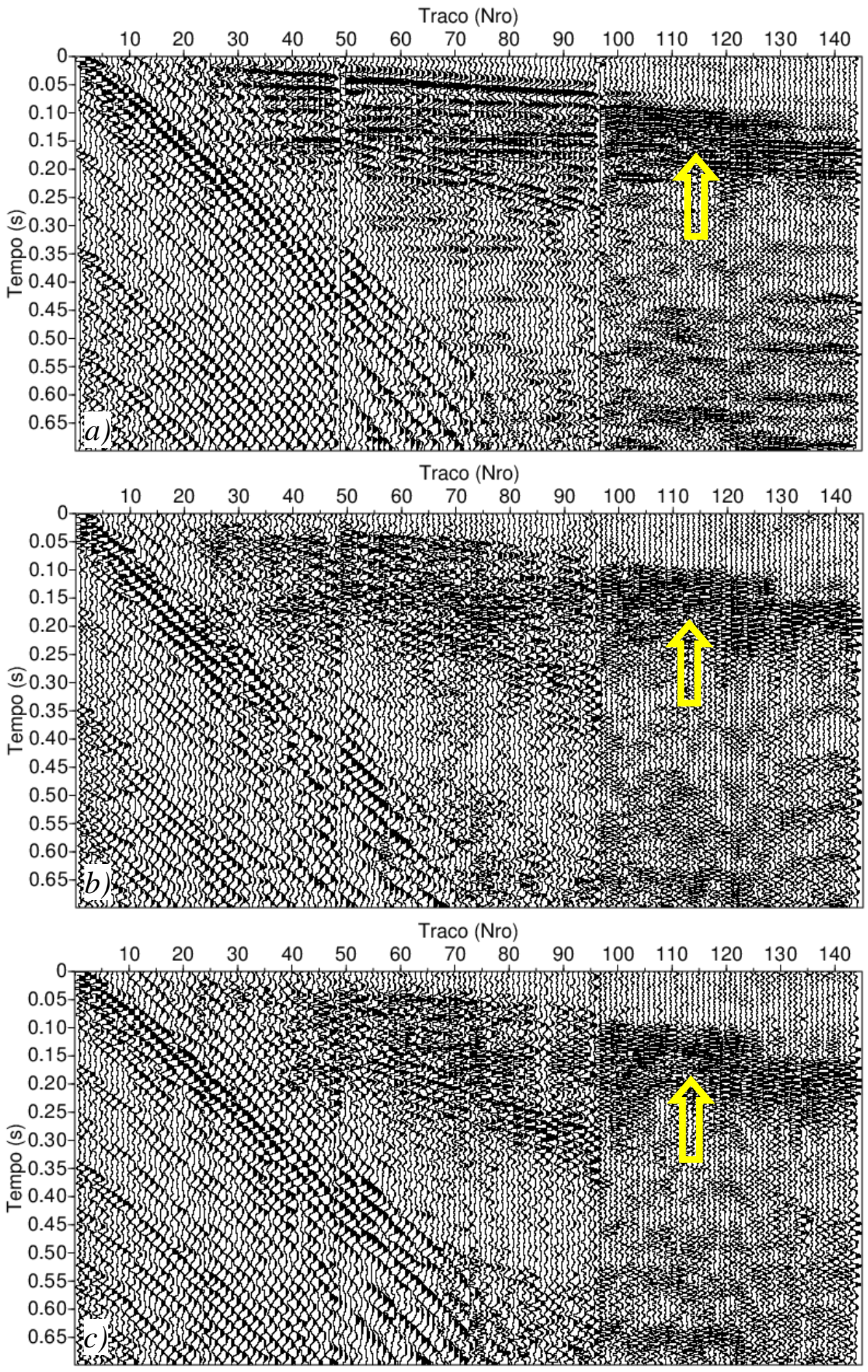

Figura 7.1.2: Sismogramas do teste de ruído com o compactador, área de estudo Colônia: a) componente vertical; b) componente radial e c) componente transversal. A seta amarela indica a energia da onda PP. 


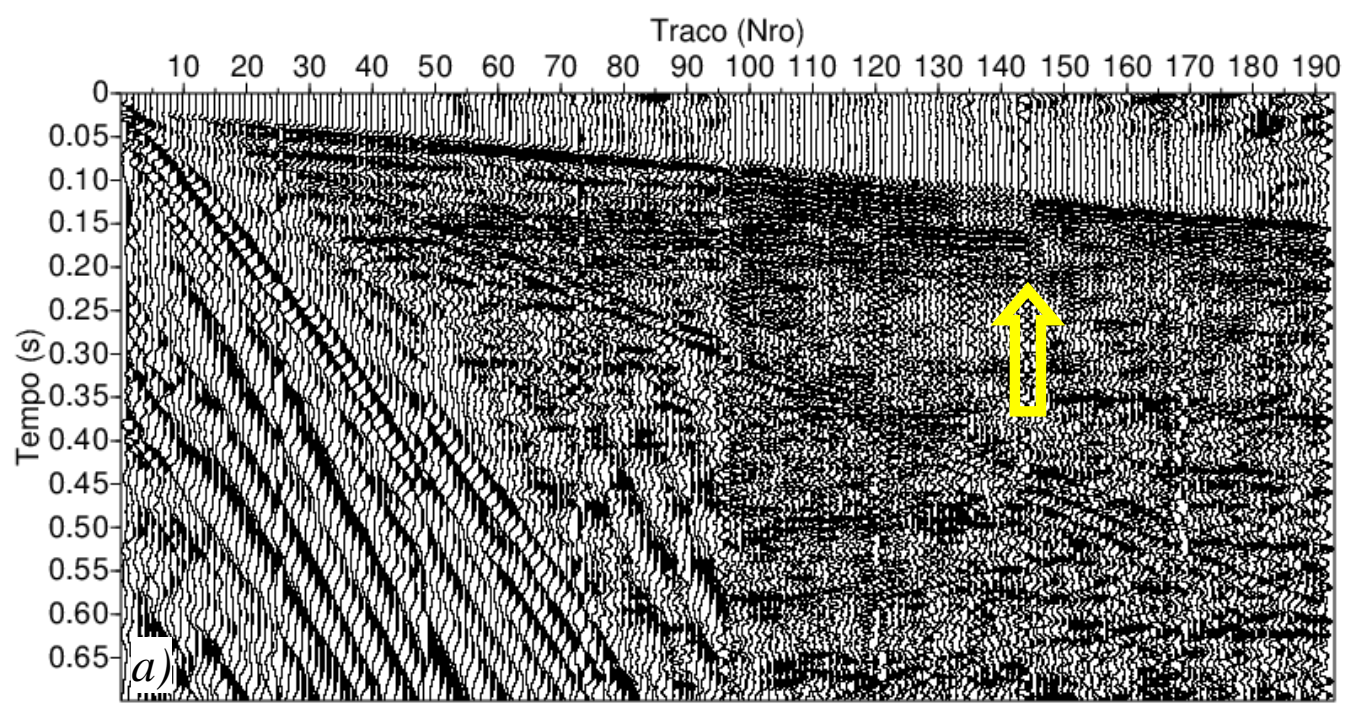

Traco (Nro)

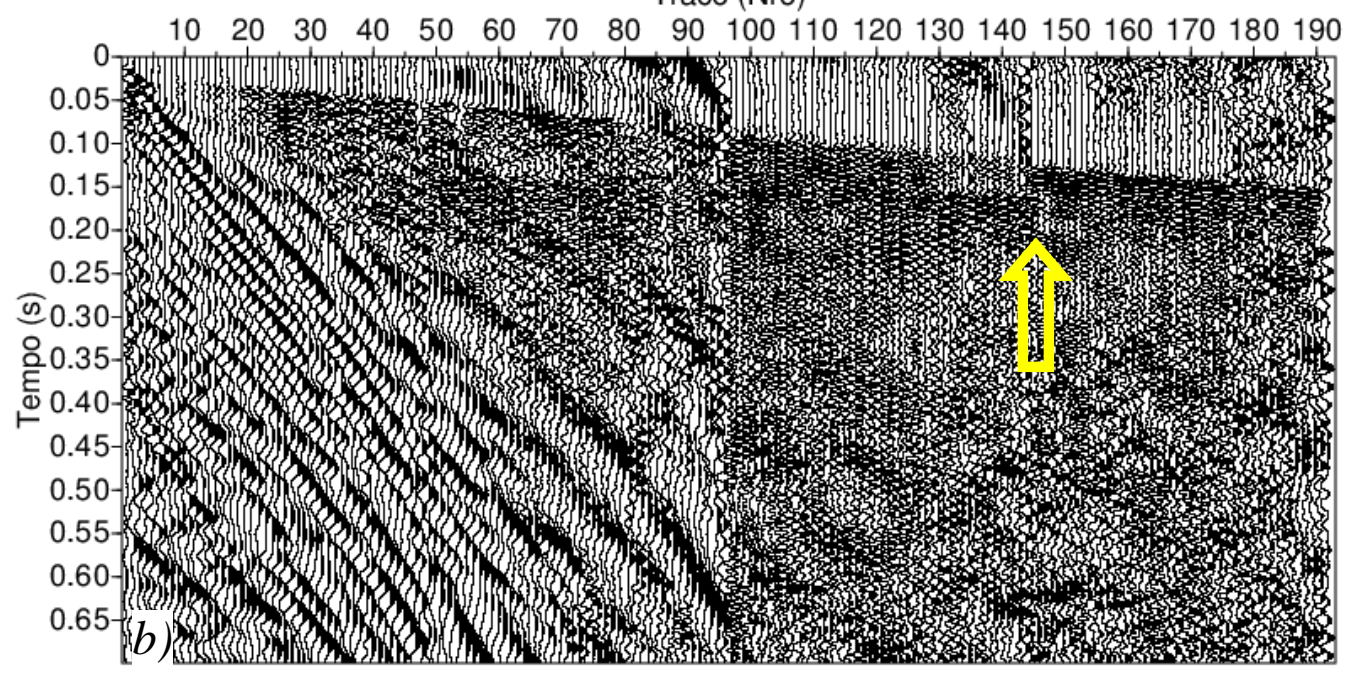

Traco (Nro)

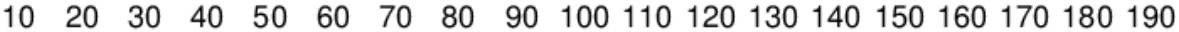

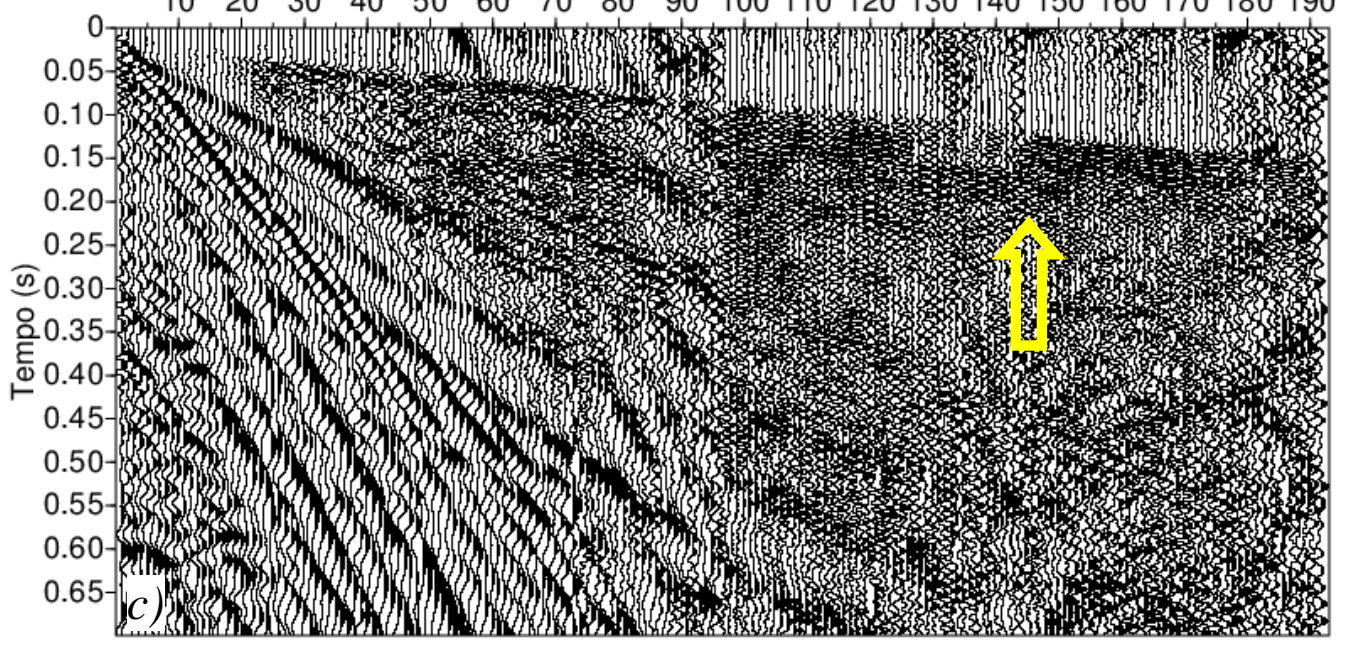

Figura 7.1.3: Sismogramas do teste de ruído com a marreta, área de estudo Colônia: a) componente vertical; b) componente radial e c) componente transversal. A seta amarela indica a energia da onda $P P$. 


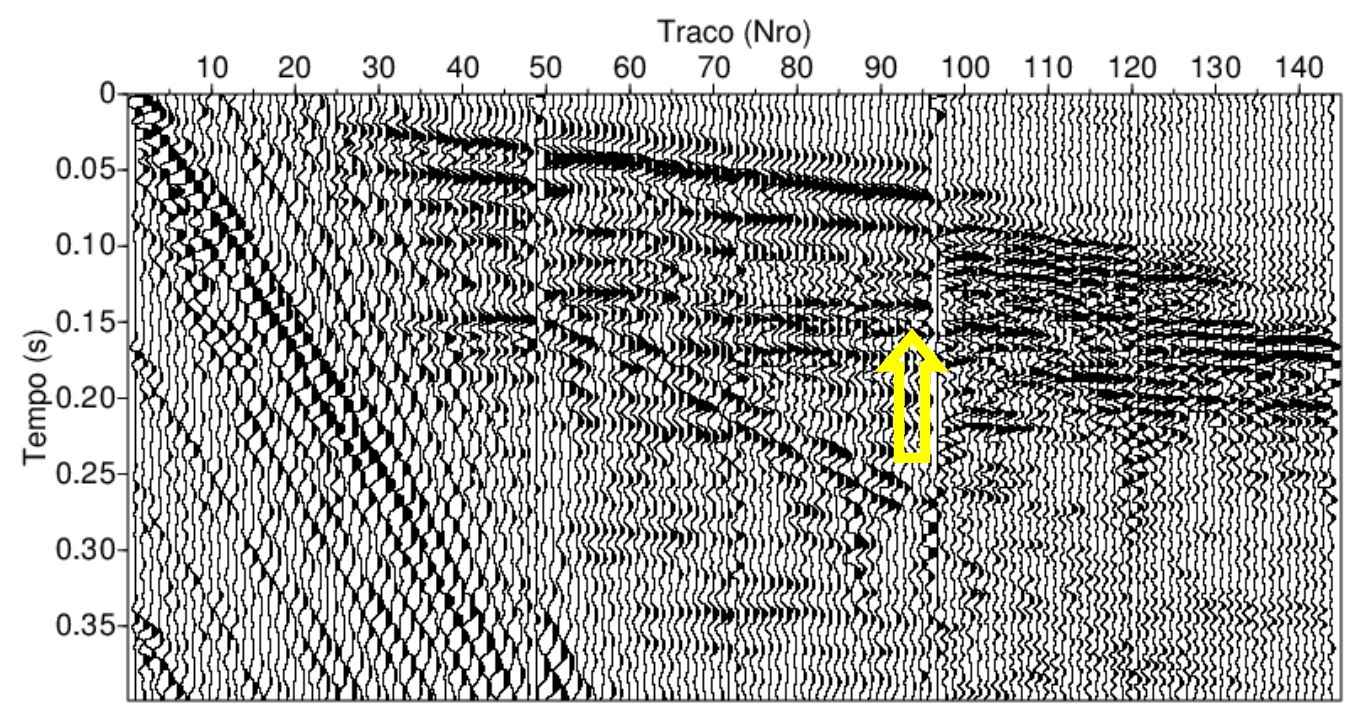

Figura 7.1.4: Sismograma de componente vertical do teste de ruído com o compactador (0 -0.4 segundos). Área de estudo: Colônia.

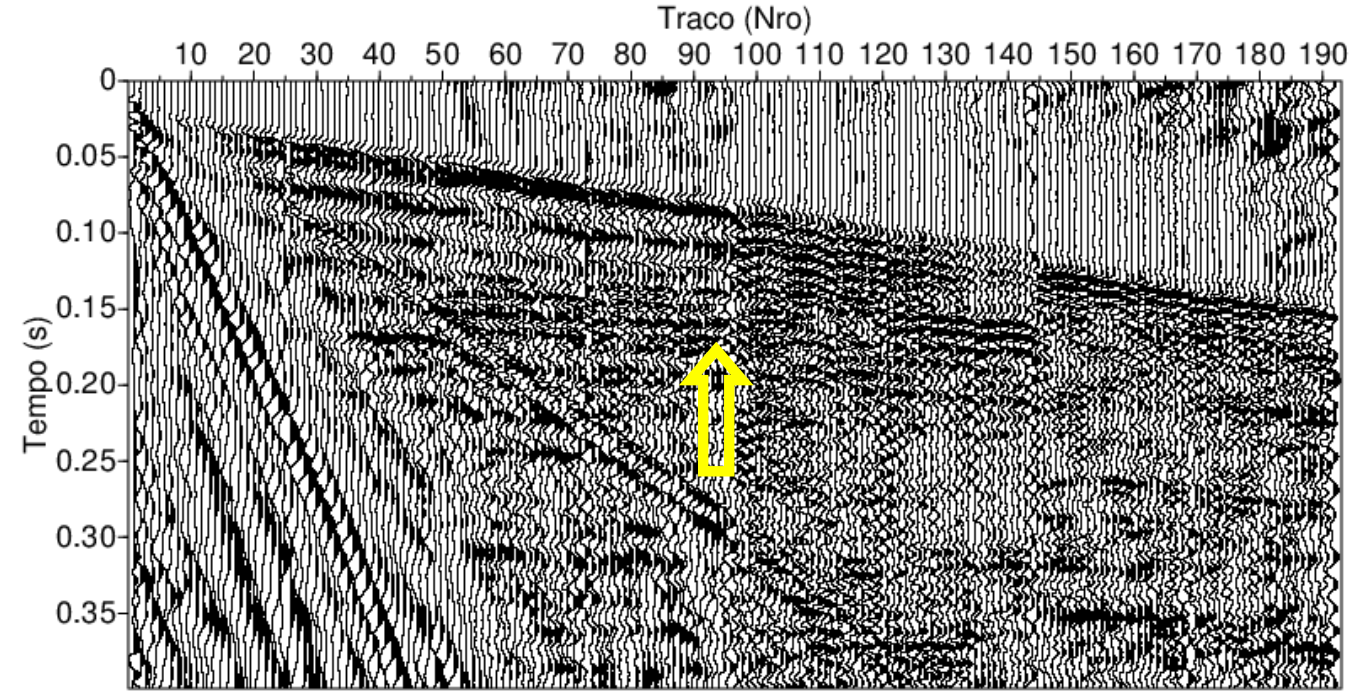

Figura 7.1.5: Sismograma de componente vertical do teste de ruído com a marreta (0 -0.4 segundos). Área de estudo: Colônia. A seta amarela indica a energia da onda PP.

possível observar que o registro adquirido com o compactador presenta oscilações próprias de um solo composto por substrato solto. Existe uma diferencia entre as primeiras quebras das seções obtidas com deferentes fontes correspondente a uns 0.05 segundos (Figura 7.1.8a). Nas componentes horizontais $(7.1 .2 \mathrm{~b}, \mathrm{c}$ e $7.1 .3 \mathrm{~b}, \mathrm{c})$ também se observa a energia das ondas PP mas não é observada a onda convertida.

A partir dos registros obtidos com a marreta se determinaram os parâmetros de aquisição para a área de Colônia: offset mínimo de 24 metros e máximo de 164, espaçamento de 2 metros entre os geofones e entre os tiros, intervalo de amostragem em tempo de $0.5 \mathrm{~ms}$.

Nas Figuras 7.1.6 e 7.1.7 se mostram os registros obtidos com o compactador e a marreta, respectivamente, na área de campus da USP. A componente vertical (Figuras 7.1.6a e 7.1.7a) apresenta a energia das ondas tipo PP. Nas componentes horizontais (7.1.6b e 7.1.7b) 

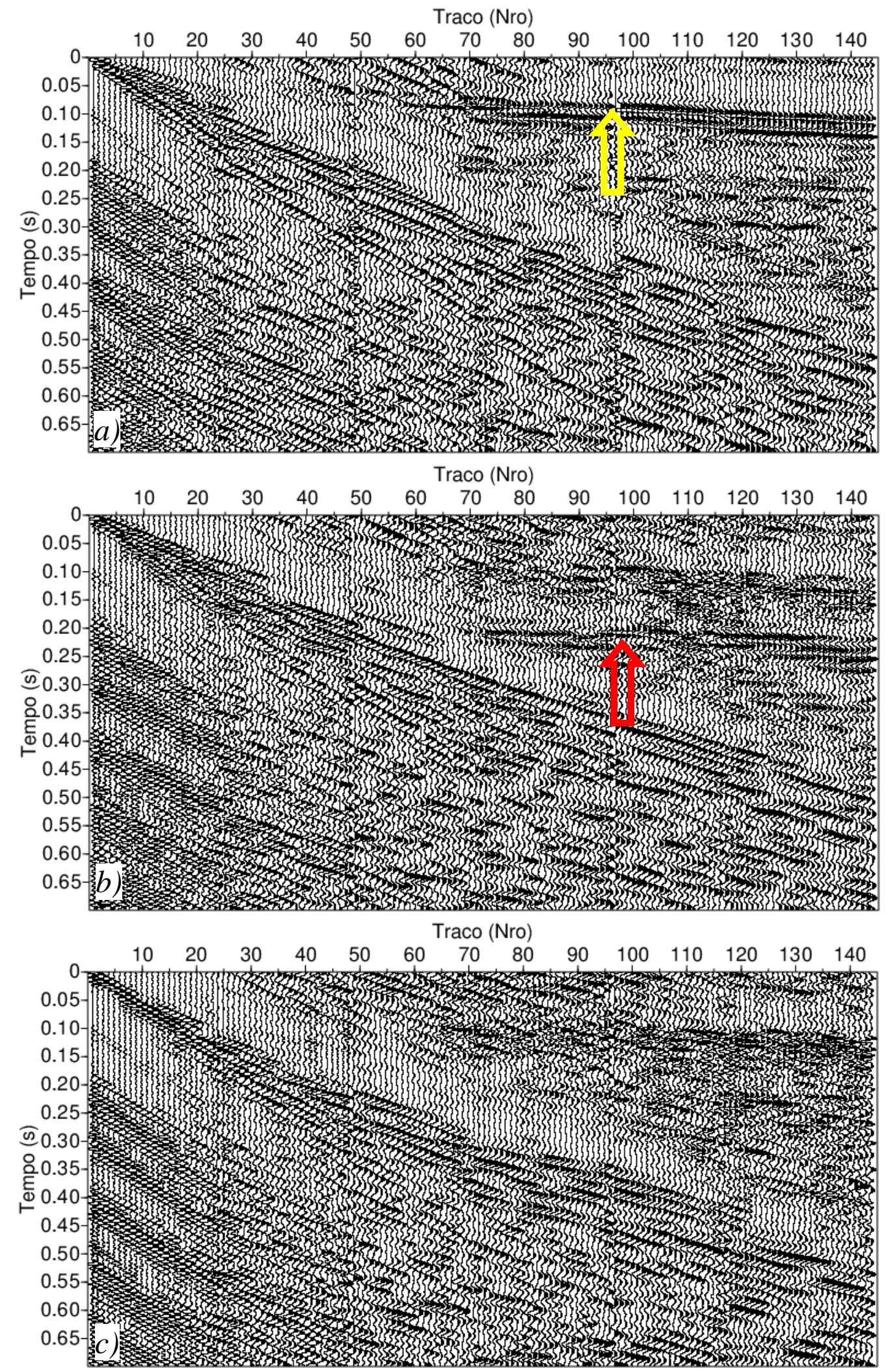

Figura 7.1.6: Sismogramas do teste de ruído com o compactador, área de estudo Campus da USP: a) componente vertical; b) componente radial e c) componente transversal. As setas amarela e vermelha indicam a energia da onda PP e PS respectivamente. 

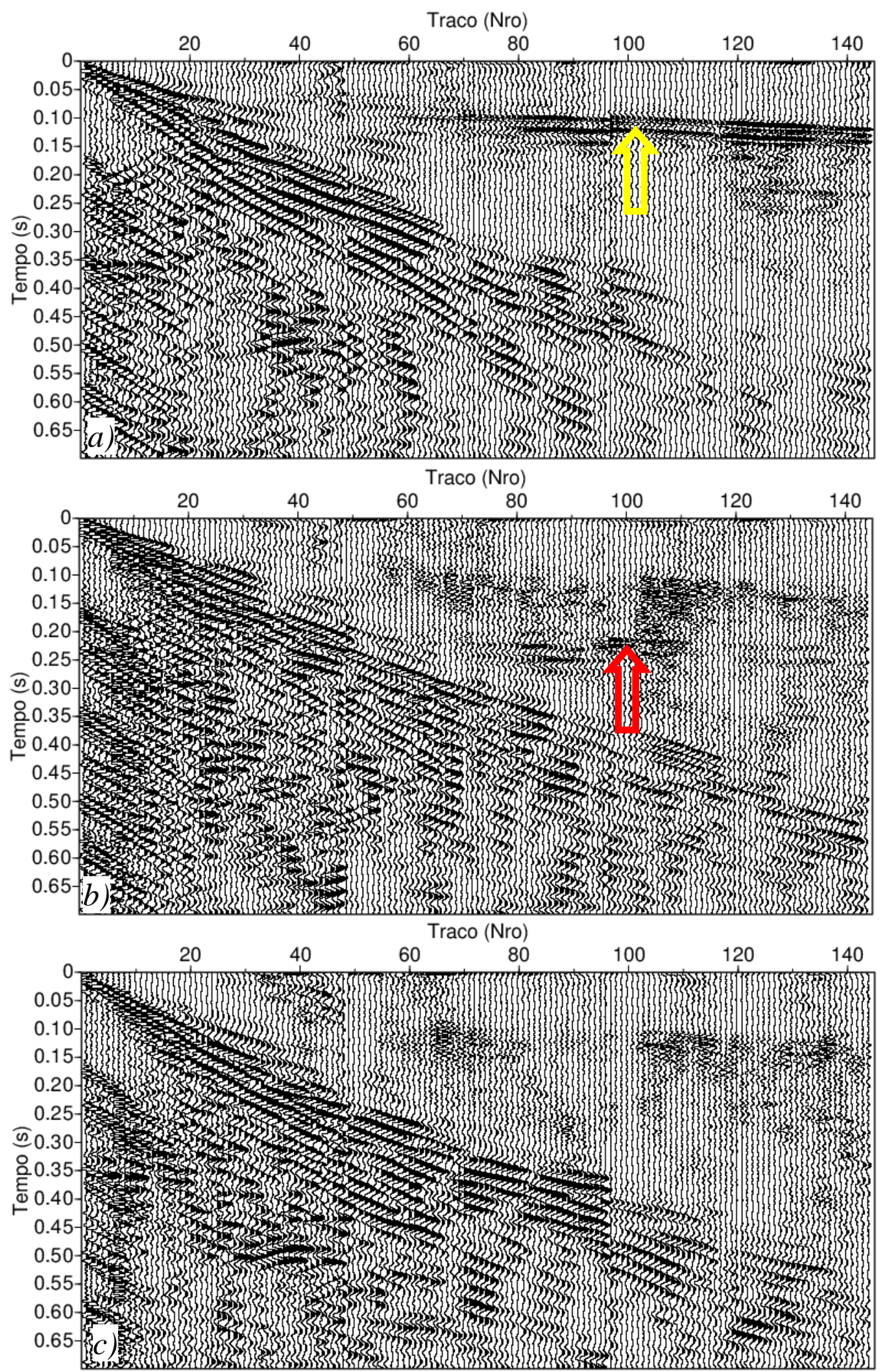

Figura 7.1.7: Sismogramas do teste de ruído com a marreta, área de estudo Campus da USP: a) componente vertical; b) componente radial e c) componente transversal. As setas amarela e vermelha indicam a energia da onda PP e PS respectivamente. 


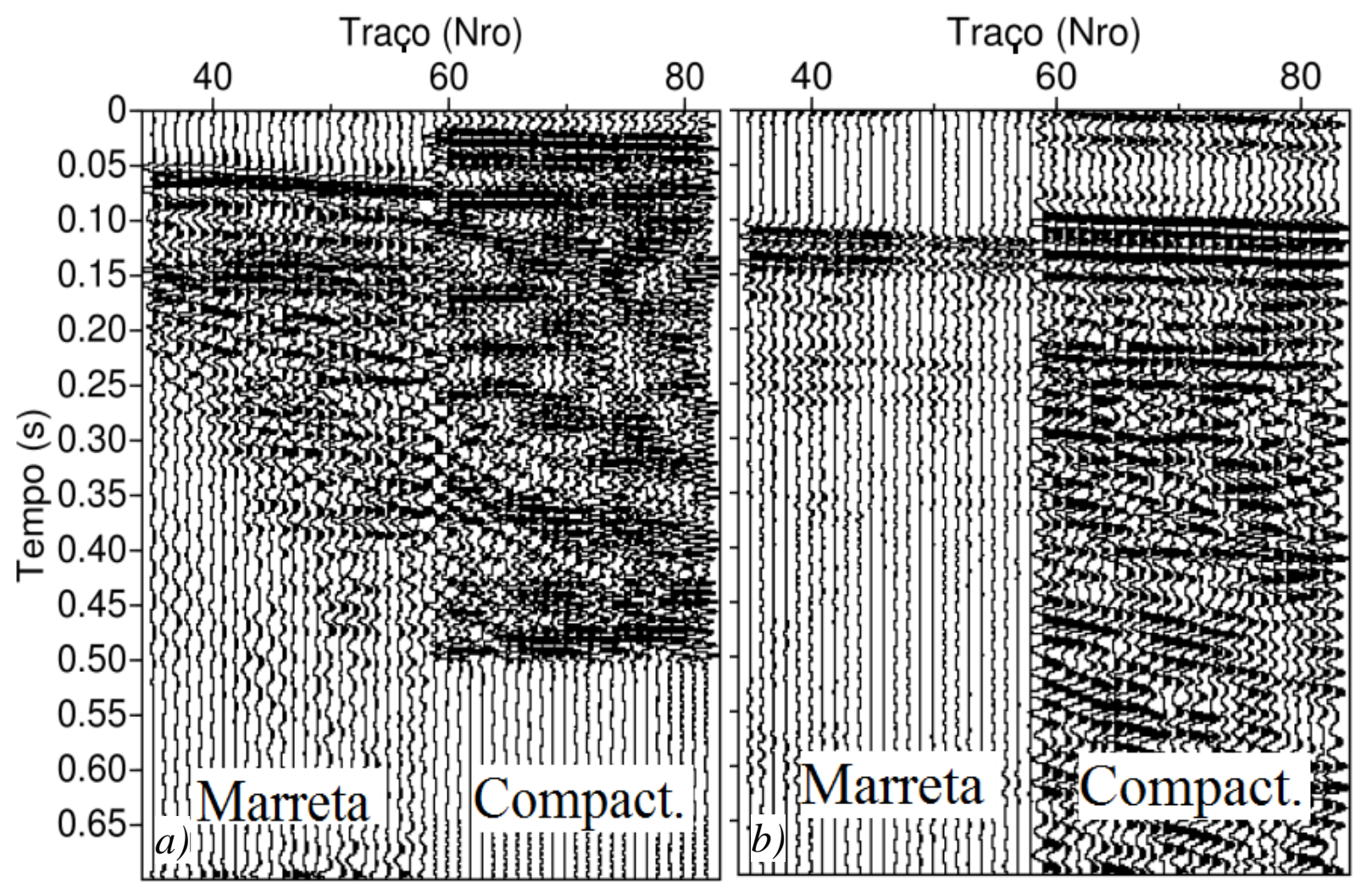

Figura 7.1.8: Sismogramas de teste de ruído concatenados. Do lado esquerdo se encontra a seção adquirida com a marreta e à direita seção adquirida com o compactador: a) Colônia; b) Campus da USP.

se observam as energias da onda PP assim como a da onda convertida. Os registros apresentam assinaturas de fonte diferentes (Figura 7.1.7b), sendo que o registro adquirido com a marreta é consistente com uma fonte impulsiva e o registro obtido com o compactador é consistente com uma tentativa de reconstrução de ondícula de fase zero (devido à operação de correlação realizada para a obtenção do sismograma). Devido a esse fato, existe uma diferença entre as primeiras quebras dos sismogramas obtidos com deferentes fontes correspondente a uns 0.025 segundos.

Como na área do campus da USP a aquisição foi realizada numa zona urbanizada, ao lado de uma rua bastante transitada por veículos e pedestres, se escolheu a marreta como fonte, devido à dificuldade de se conseguir uma janela de aquisição de 30 segundos livre de ruídos contaminantes para o emprego do compactador. A partir de registro obtido com a marreta se determinaram como parâmetros de aquisição: offset mínimo de 40 metros e máximo de 118, espaçamento de 2 metros entre os geofones e entre os tiros, e intervalo de amostragem de 0,5 ms (ver Anexo). 


\subsection{Aquisição na área de Colônia}

Foram adquiridos 238 metros de sísmica multicomponente (3C) na Cratera de Colônia. A linha 2D foi orientada relativamente ao suposto centro geométrico da estrutura (Figura 7.2.1). Para aquisição dos dados foi usada a configuração dos cabos ilustrada na Figura 7.2.2, realizando deslocamentos de 24 geofones cada 24 tiros.

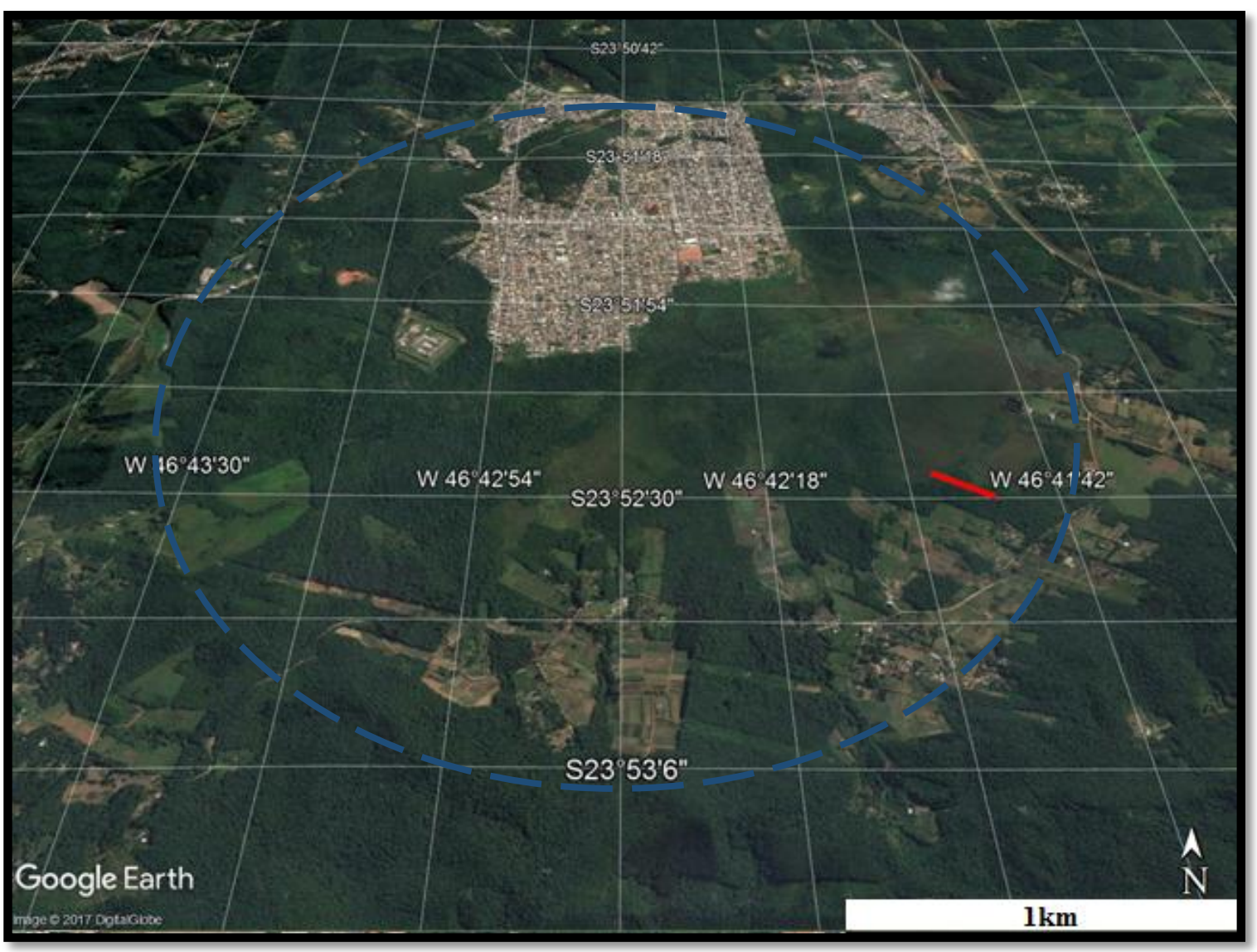

Figura 7.2.1: Cratera de Colônia. A linha vermelha indica a linha sísmica 2D adquirida na área e o círculo celeste indica os limites da estrutura.

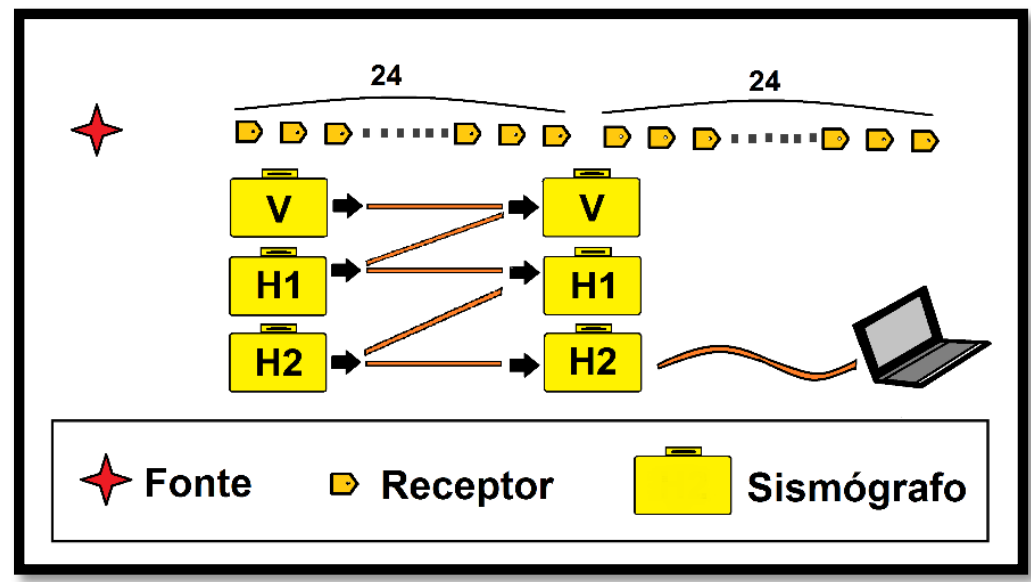

Figura 7.2.2: Disposição dos cabos na aquisição da línea na área de Cratera de Colônia. 


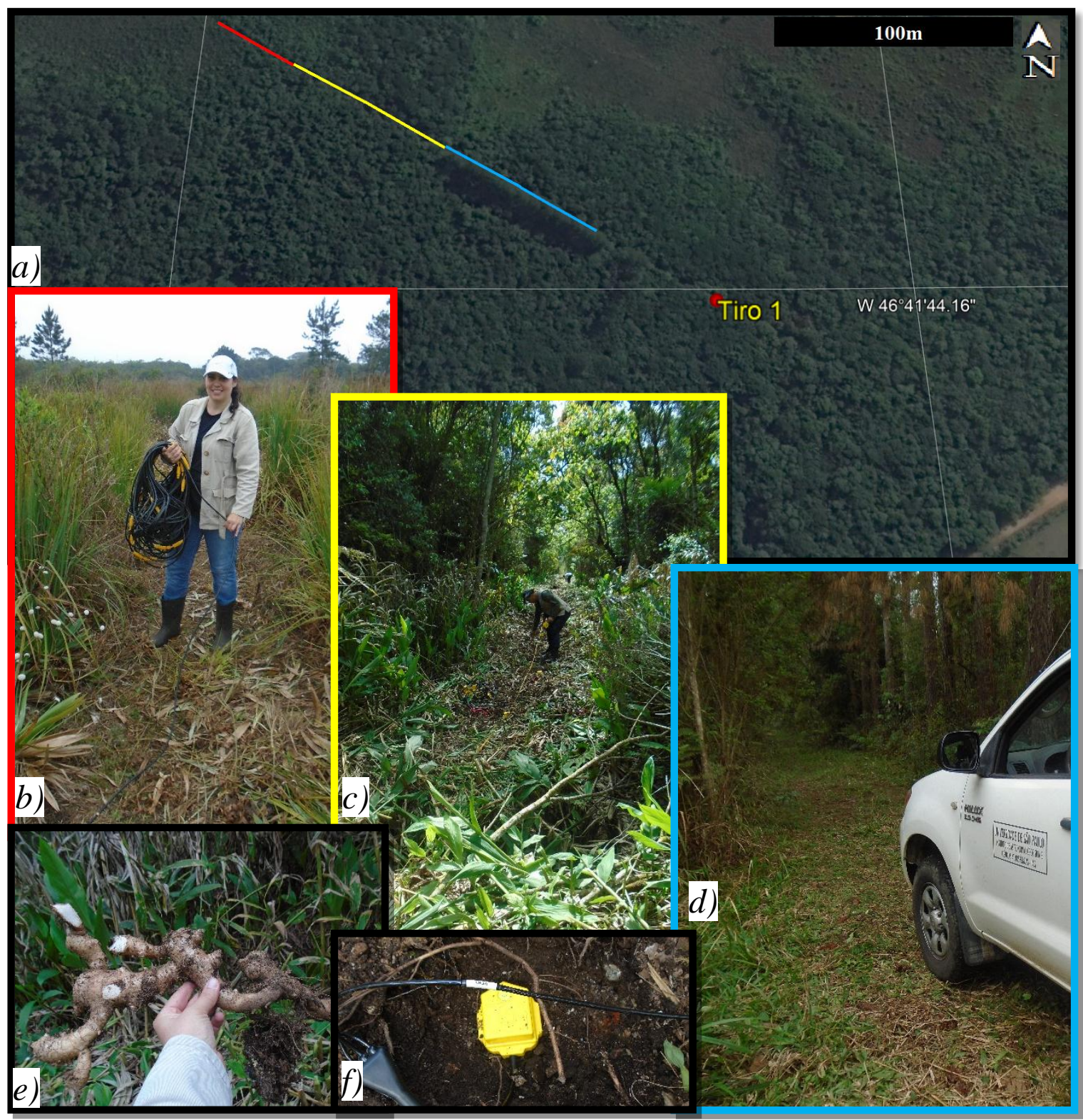

Figura 7.2.3: Cratera de Colônia: a) as linhas indicam diferentes seções da linha sísmica adquirida na área com diferentes características de superfície. As cores dos quadros das fotografias correspondem às cores das seções da linha; b) ao final da linha (seção vermelha), mais próximo ao centro da estrutura, se observa uma clareira com terreno semi - pantanoso; c) seção média (amarela) apresenta um solo úmido, com a presença de tubérculos, cascalhos e raízes de arbustos; d) seção inicial da linha (celeste) apresenta solo relativamente seco, compactado e com presença de raízes de árvores; f) escombros; e) tubérculos.

A colocação da linha foi obstaculizada pela presença de um canal artificial de drenagem (Figura 7.2.3c), o que produziu a perda de dois intervalos de geofones. A superfície do terreno sofre uma mudança significativa antes e depois do canal, passando de um solo seco, compactado e com presença de raízes de árvores (Figura 7.2.3d) a um solo úmido, com a presença de tubérculos, entulhos de construção (despejados para permitir o acesso de 
pedestres) e raízes de arbustos (Figura 7.2.3e). Ao final da linha se observa uma clareira com terreno semi-pantanoso (Figura 7.2.3b).

\subsection{Aquisição na área de Campus da USP}

Foram adquiridos 170 metros de sísmica multicomponente (3C) na área do Campus da Universidade de São Paulo (Figura 7.3.1). Para aquisição dos dados foi usada a configuração dos cabos ilustrada na Figura 7.3.2, realizando deslocamentos de 8 geofones cada 8 tiros. O sítio apresenta características homogêneas de superfície.

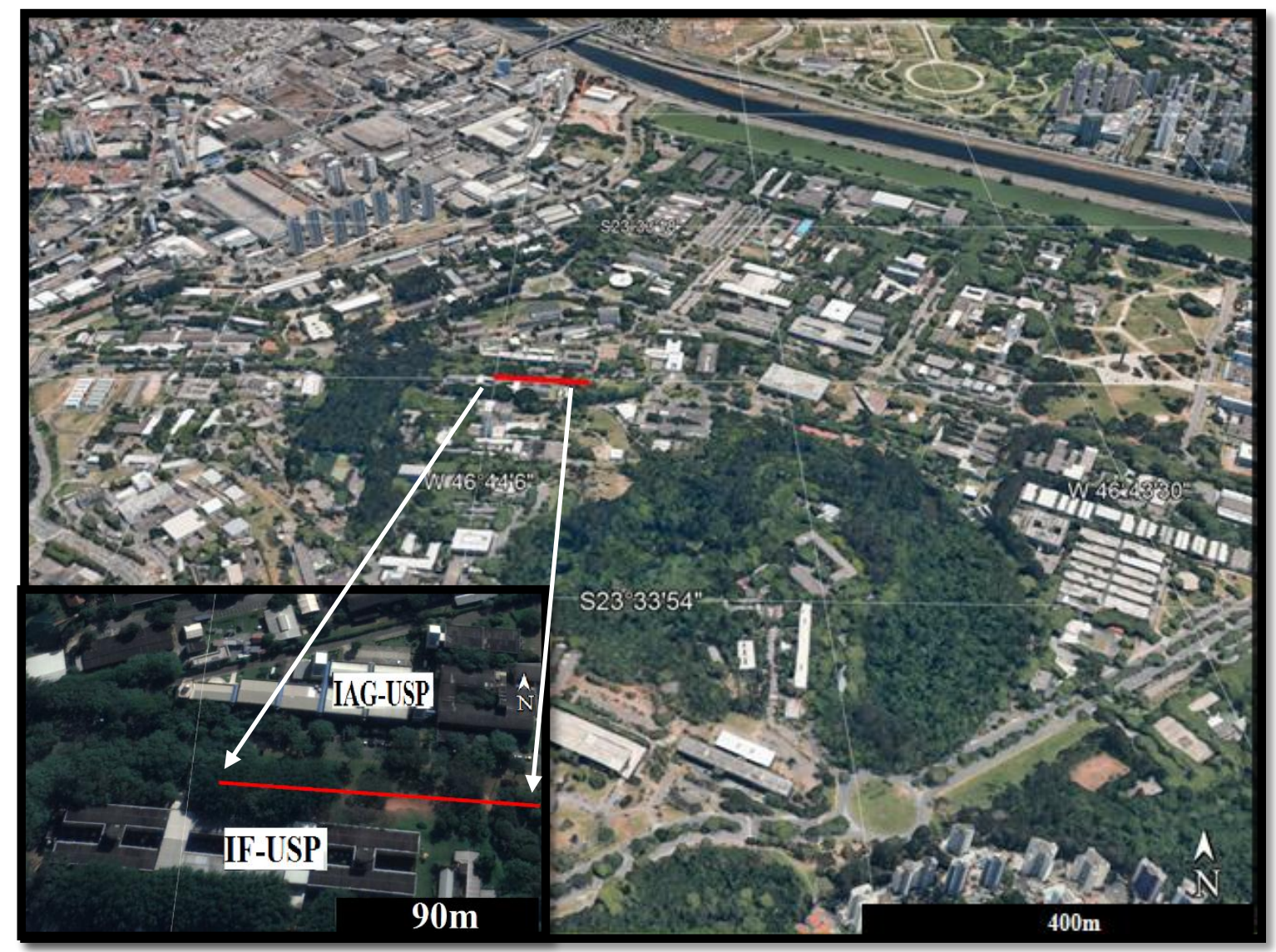

Figura 7.3.1: Área de estudo: Campus da USP. A linha vermelha indica a linha sísmica 2D adquirida. 


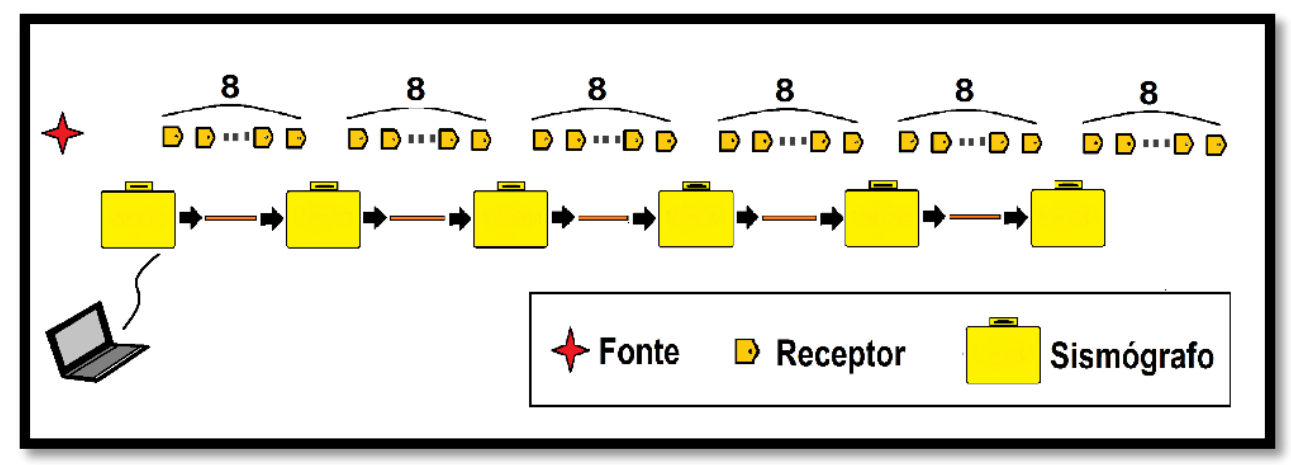

Figura 7.3.2: Disposição dos cabos na aquisição da linha na área do Campus da USP. 


\section{Processamento: área de Colônia}

\subsection{Controle de qualidade da geometria e cálculo de ACCP}

O controle de qualidade da geometria introduzida aos dados pode ser realizado mediante a análise do gráfico das posições de tiros e receptores (Figura 8.1.1). Nesta figura é apresentada a geometria da aquisição introduzida nos dados sísmicos de Colônia. Na Figura 8.1.1 se observa a disposição de fontes e receptores (componentes vertical e horizontais) tendo como origem (estaca $\mathrm{x}=0$ ) a primeira posição de fonte e sendo FLDR (designação do Seismic Unix - original field record number) o número do registro sísmico de campo (conjunto de tiro).

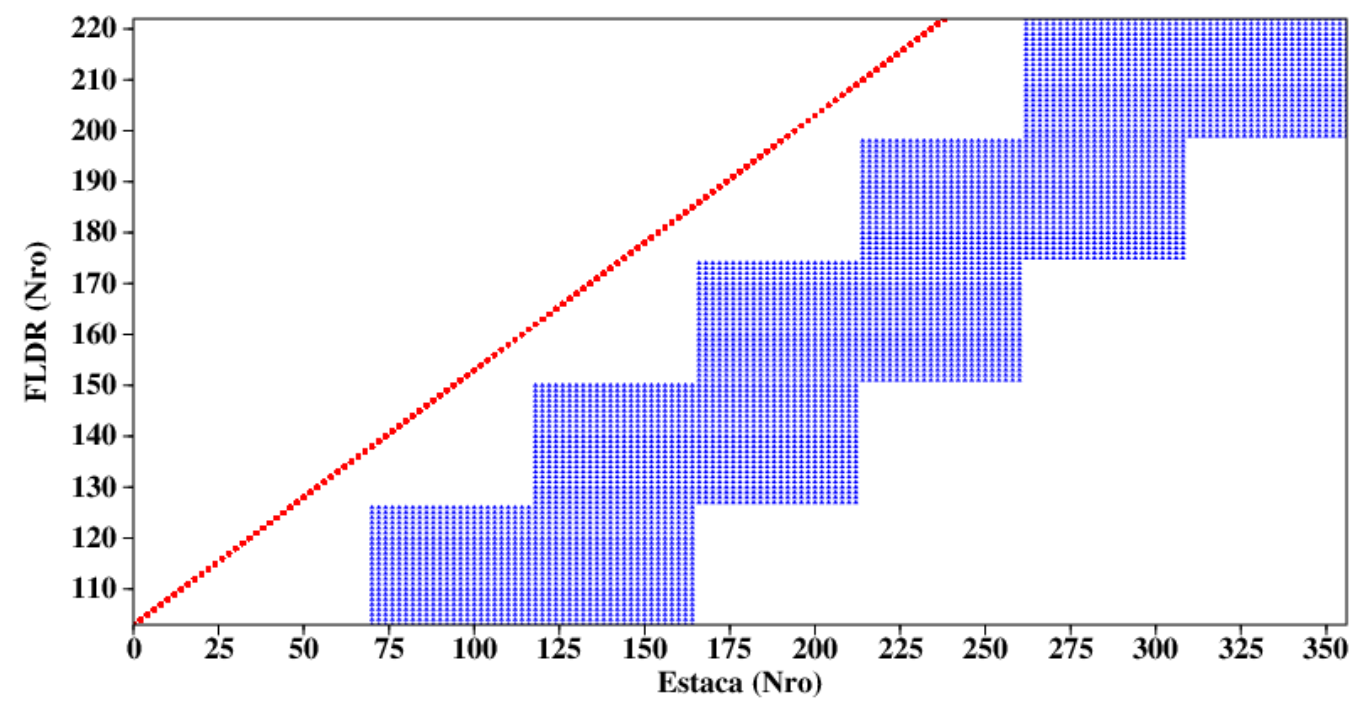

Figura 8.1.1: Geometria de aquisição. A posição das fontes e receptores estão referidas aos números de estacas a partir de zero para o primeiro tiro e os números de tiros estão vinculados aos números de arquivo de aquisição (FLDR). Os pontos vermelhos indicam as posições de fontes e os pontos azuis indicam as posições de receptores.

Na Tabela 8.1.1 se mostram as faixas de alguns valores dos cabeçalhos dos traços sísmicos da componente vertical obtidos usando o comando 'surange' do SU. As componentes são identificadas usando a palavra-chave 'trid', onde trid=12 identifica a componente vertical, trid=14 e trid=13 identificam componentes horizontais radial e transversal, respetivamente. $\mathrm{O}$ campo do cabeçalho denominado 'd2' foi usado para alocar os valores de ACCP calculados para as componentes horizontais. Para o cálculo do ponto de conversão foi aplicada a Equação 6.3.4, usando a razão $\mathrm{Vp} / \mathrm{Vs}$ constante e analisando as seções resultantes numa faixa de valores da razão entre 1.5 e 5 . O valor da palavra-chave 'd2' assim calculado é inserido no 
cabeçalho do dado usando o comando 'suchw' do SU. Na Tabela 8.1.2 se mostram os valores de $\mathrm{Vp} / \mathrm{Vs}$ que foram analisados e os valores de $\mathrm{G}$ associados. É notável que para valores menores de razão $\mathrm{Vp} / \mathrm{Vs}$, o ponto de conversão calculado (ACCP) fica próximo do ponto médio comum e para valores de $\mathrm{Vp} / \mathrm{Vs}$ maiores fica próximo da coordenada (valor da estaca) do receptor. Como as ondas convertidas não foram visualizadas nos sismogramas de tiro, nem se dispunha de valores da velocidade da onda $S$ para o local dos ensaios, foram considerados os valores de $\mathrm{Vp} / \mathrm{Vs}$ numa ampla faixa analisando as seções empilhadas resultantes e a multiplicidade em cada caso. Como para o caso de $\mathrm{Vp} / \mathrm{Vs}=3$ obteve-se o maior valor de multiciplidade, esse valor da razão foi o escolhido para se realizar o processamento das componentes horizontais visando à visualização da energia da onda PS na seção empilhada.

Tabela 8.1.1 - As faixas dos valores dos cabeçalhos introduzidos aos dados sísmicos (exemplo de componente vertical).

\begin{tabular}{l|l|l|l}
\hline Palavra-chave & \multicolumn{1}{c}{ Descrição } & \multicolumn{2}{l}{ Faixa dos valores } \\
\cline { 3 - 4 } (Seismic Unix) & & Mínimo & Máximo/Total \\
\hline traces & Quantidade de traços & 5760 \\
fldr & Número de arquivo & 103 & 222 \\
tracf & Número de traço & 1 & 48 \\
cdp & Ponto de reflexão & 35 & 297 \\
trid & Componente & 12 & 14 \\
offset & Offset (m) & $24 \mathrm{~m}$ & $164 \mathrm{~m}$ \\
$\mathrm{sx}$ & Número de estaca de tiro & 0 & 238 \\
$\mathrm{gx}$ & Número de estaca de receptor & 70 & 356 \\
$\mathrm{~ns}$ & Número de amostras (tempo) & & 2000 \\
$\mathrm{dt}$ & Período de amostragem (tempo & & 500 \\
$\mathrm{~d} 2$ & em microssegundos) & & 326.5 \\
$\ldots$ & Coordenada do conjunto ACCP & 52.5 & \\
\hline
\end{tabular}

Tabela 8.1.2 - Faixas dos valores da razão Vp/Vs analisados e valores do fator G correspondentes.

\begin{tabular}{c|c}
\hline $\mathrm{Vp} / \mathrm{Vs}$ & $\mathrm{G}=1 /(\mathrm{Vs} / \mathrm{Vp}+1)$ \\
\hline 1,5 & 0,600 \\
2 & 0,667 \\
2,5 & 0,714 \\
3 & 0,750 \\
3,5 & 0,778 \\
4 & 0,800 \\
4,5 & 0,818 \\
5 & 0,833 \\
\hline
\end{tabular}


A Figura 8.1.2 mostra os pontos médios comuns calculados (CMP) para a componente vertical, a Figura 8.1.3 mostra os ACCP (ponto assintótico de conversão comum) calculados considerando $\mathrm{Vp} / \mathrm{Vs}=3$ e a Figura 8.1.4 a multiplicidade dos traços resultante.

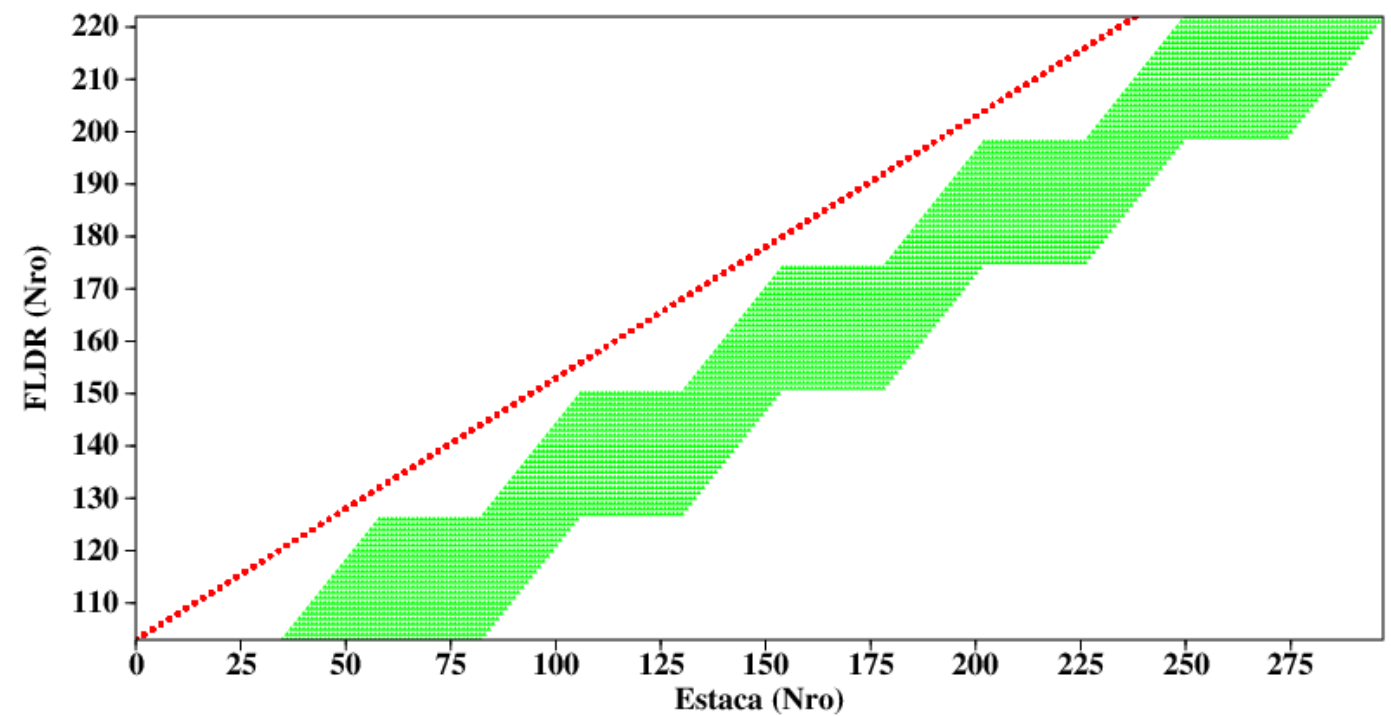

Figura 8.1.2: Geometria de aquisição. A posição das fontes e pontos meios comuns estão referidas aos números de estacas a partir de zero para o primeiro tiro e aos números de arquivo de aquisição (FLDR) a partir de 103. Os pontos vermelhos indicam as posições de fontes e os pontos verdes indicam as posições de CMP calculados.

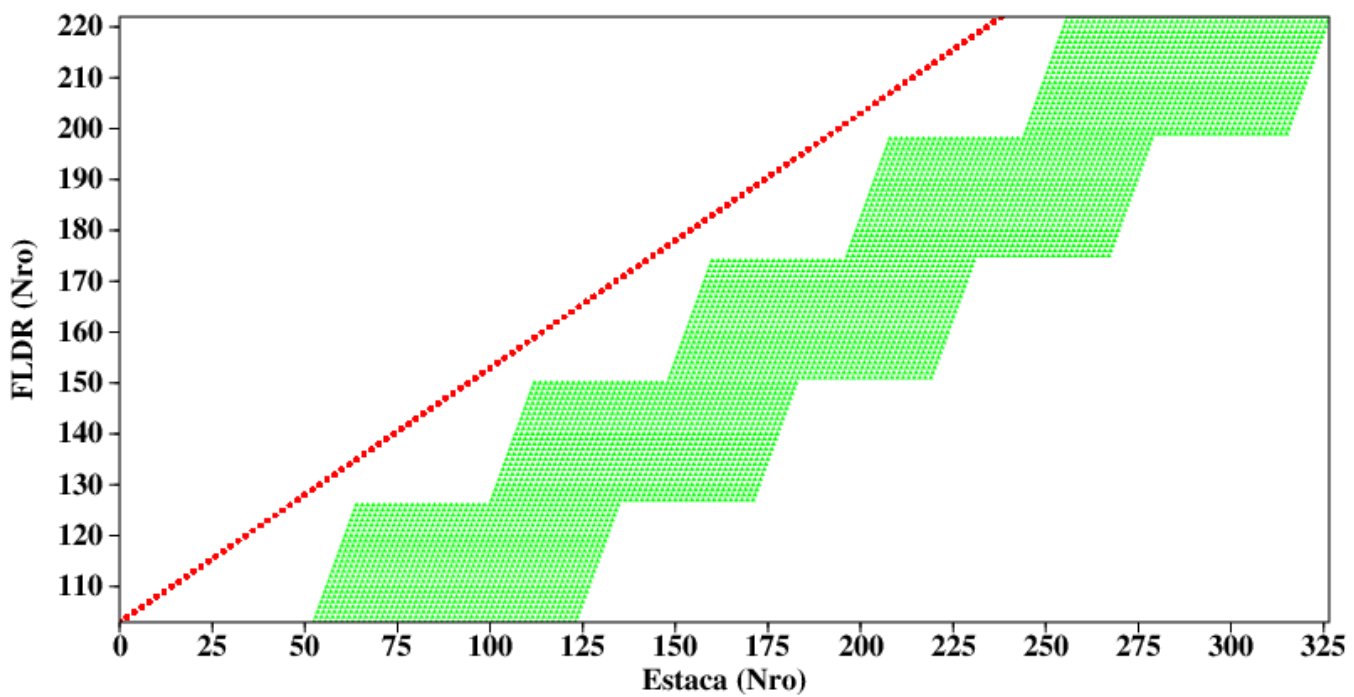

Figura 8.1.3: Geometria de aquisição. A posição das fontes e pontos assintóticos de conversão comuns (ACCP) com $\mathrm{Vp} / \mathrm{Vs}=3$, os quais estão referidas aos números de estacas a partir de zero para o primeiro tiro e aos números de arquivo de aquisição (FLDR) a partir de 103. Os pontos vermelhos indicam as posições de fontes e os pontos verdes indicam as posições de CMP calculados. 

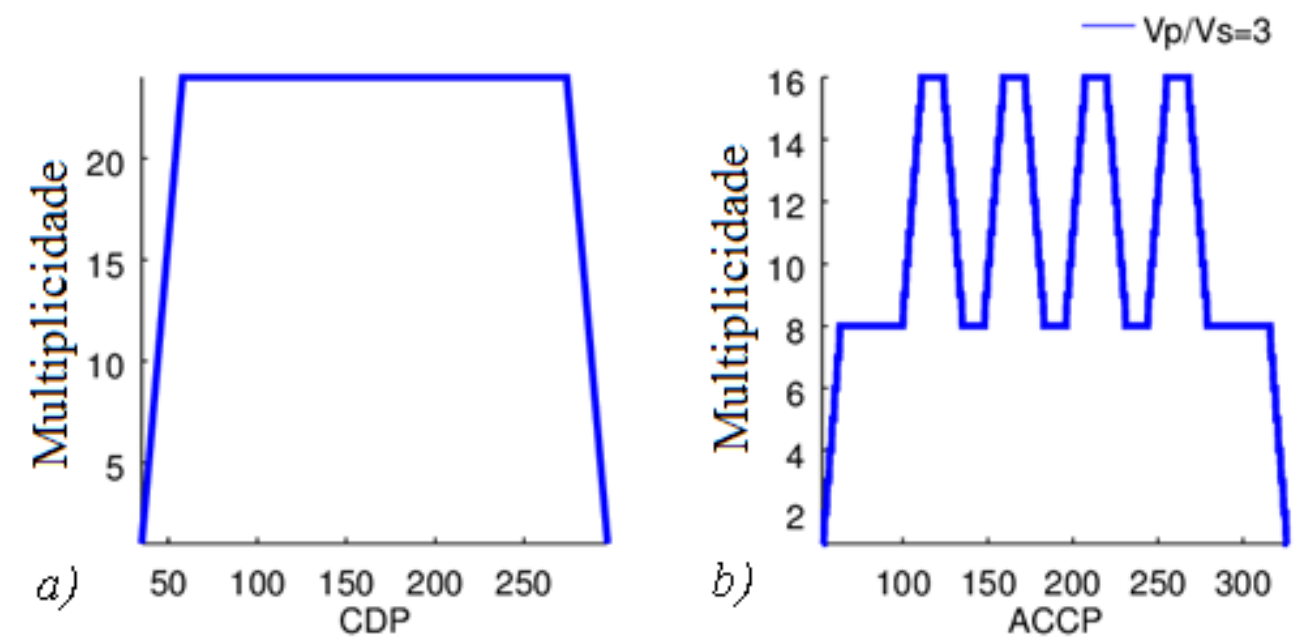

Figura 8.1.4: A multiciplidade de traços a) para CDP da componente vertical; b) para ACCP das componentes horizontais $(\mathrm{Vp} / \mathrm{Vs}=3)$.

\subsection{Edição dos traços}

Na edição de traços, foram eliminados os traços ruidosos, como os originários da transposição do canal de drenagem quando não foram instalados geofones (Figura 8.2.1).

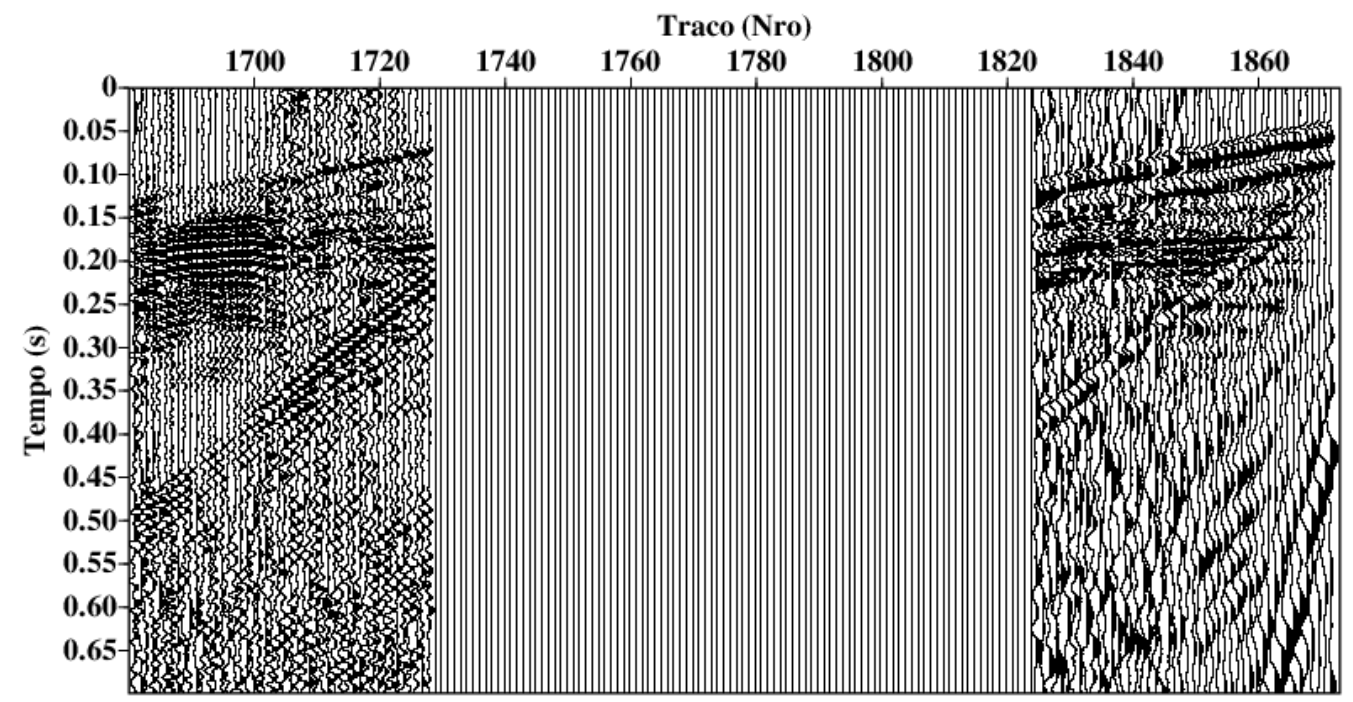

Figura 8.2.1: Conjuntos de receptor comum - componente vertical com traços ruidosos zerados.

\subsection{Análise espectral}

As figuras a seguir mostram os sismogramas e respectivos espectros de amplitude dos conjuntos de tiros adquiridos com offsets mínimos de 60 metros para diferentes posições da linha sísmica no sentido lado exterior da estrutura (S) para o centro (N): FLDR 108, FLDR 156 e FLDR 204 (Figuras 8.3.1, 8.3.2 e 8.3.3, respectivamente). As Figuras 8.3.1 d,e,f, 8.3.2 d,e,f e 8.3.3 d,e,f apresentam os espectros de frequência na faixa de linearidade do geofone 
(até $250 \mathrm{~Hz}$ ), e as Figuras 8.3.4 a,b,c os espectros das componentes verticais na faixa de 0-160 Hz.

A partir das Figuras 8.3.1, 8.3.2, 8.3.3 e 8.3.4 é possível observar que nas três componentes existe a diminuição na relação SNR no sentido do centro da estrutura, assim como o deslocamento de frequência predominante de sinal de interesse dos $90 \mathrm{~Hz}$ para os 75 Hz. Analisando os conjuntos de tiro, se conclui que a mudança na frequência principal do sinal é dependente da posição do tiro e se produz entre os tiros correspondentes aos FLDR 123 e 124 (Figura 8.3.5).
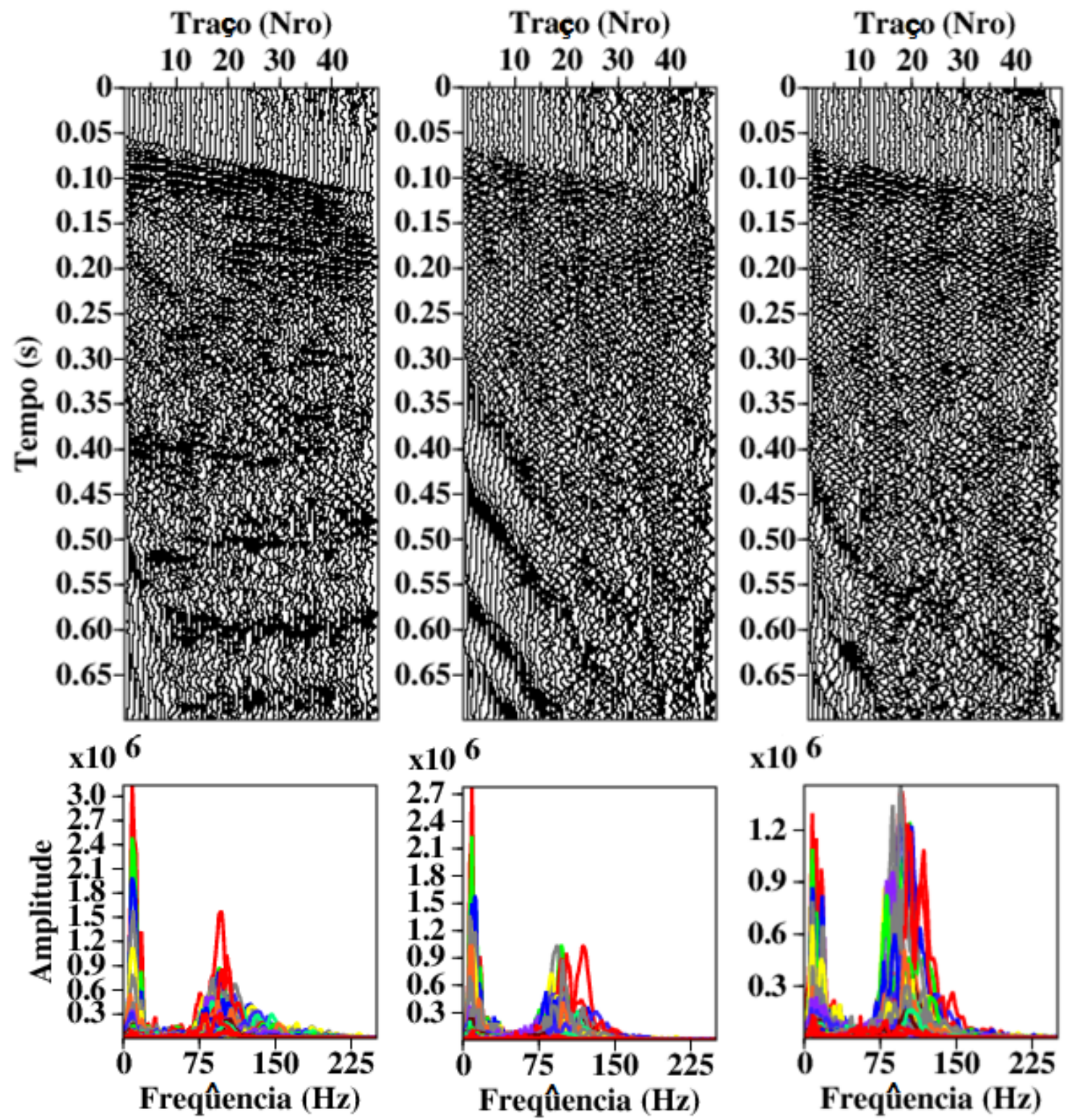

Figura 8.3.1: FLDR 108. Conjuntos de tiro das componentes a) vertical; b) horizontal radial; c) horizontal transversal e seus respectivos espectros de amplitude d), e) ef). 


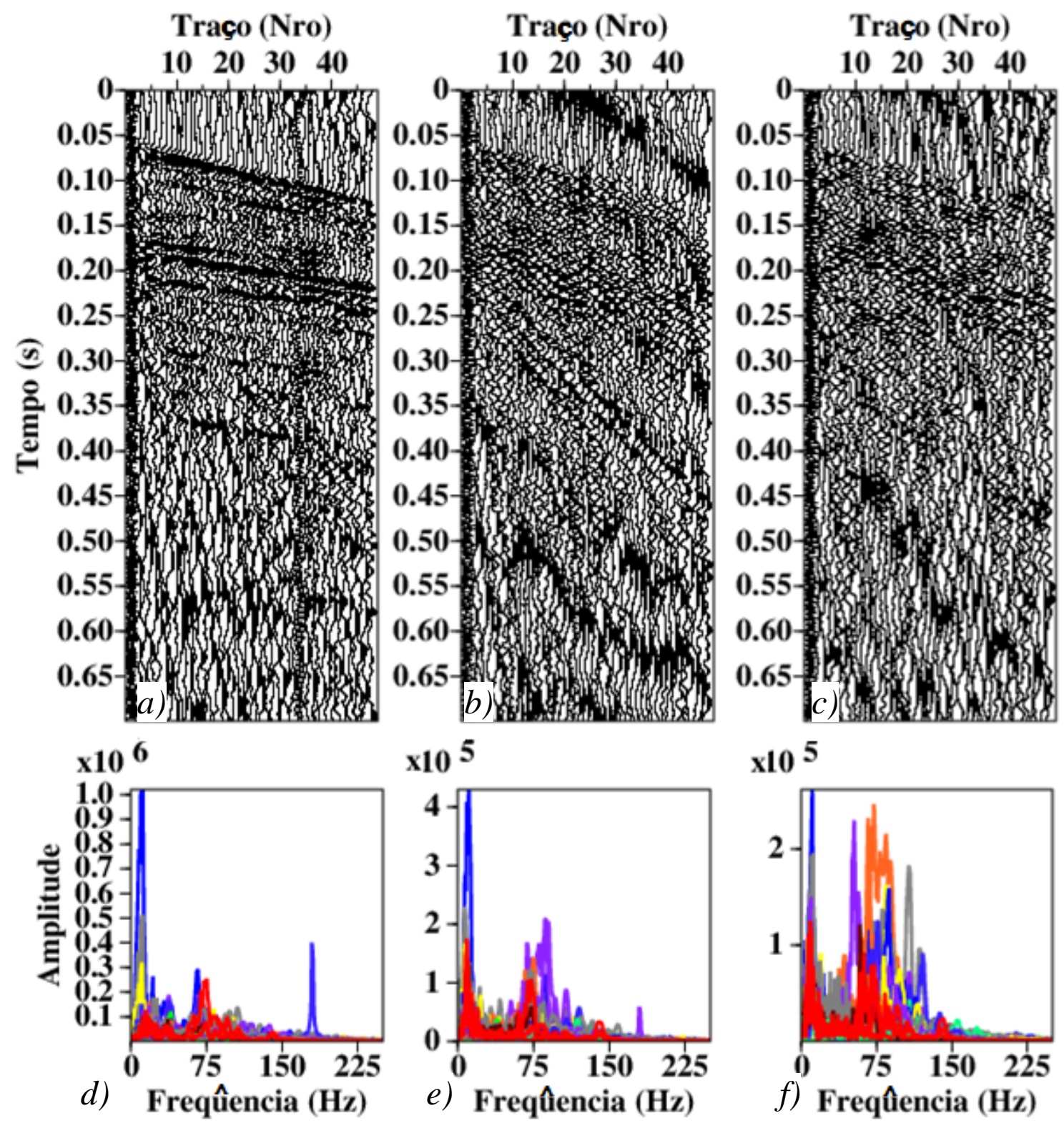

Figura 8.3.2: FLDR 156. Conjuntos de tiro das componentes a) vertical; b) horizontal radial; c) horizontal transversal e seus respectivos espectros de amplitude d), e) ef).

Nas componentes horizontais se observa sinal com frequência principal de onda PP e não é possível visualizar a energia da onda PS (Figuras 8.3.1 b,c,e,f; 8.3.2 b,c,e,f; 8.3.3 $b, c, e, f)$. 

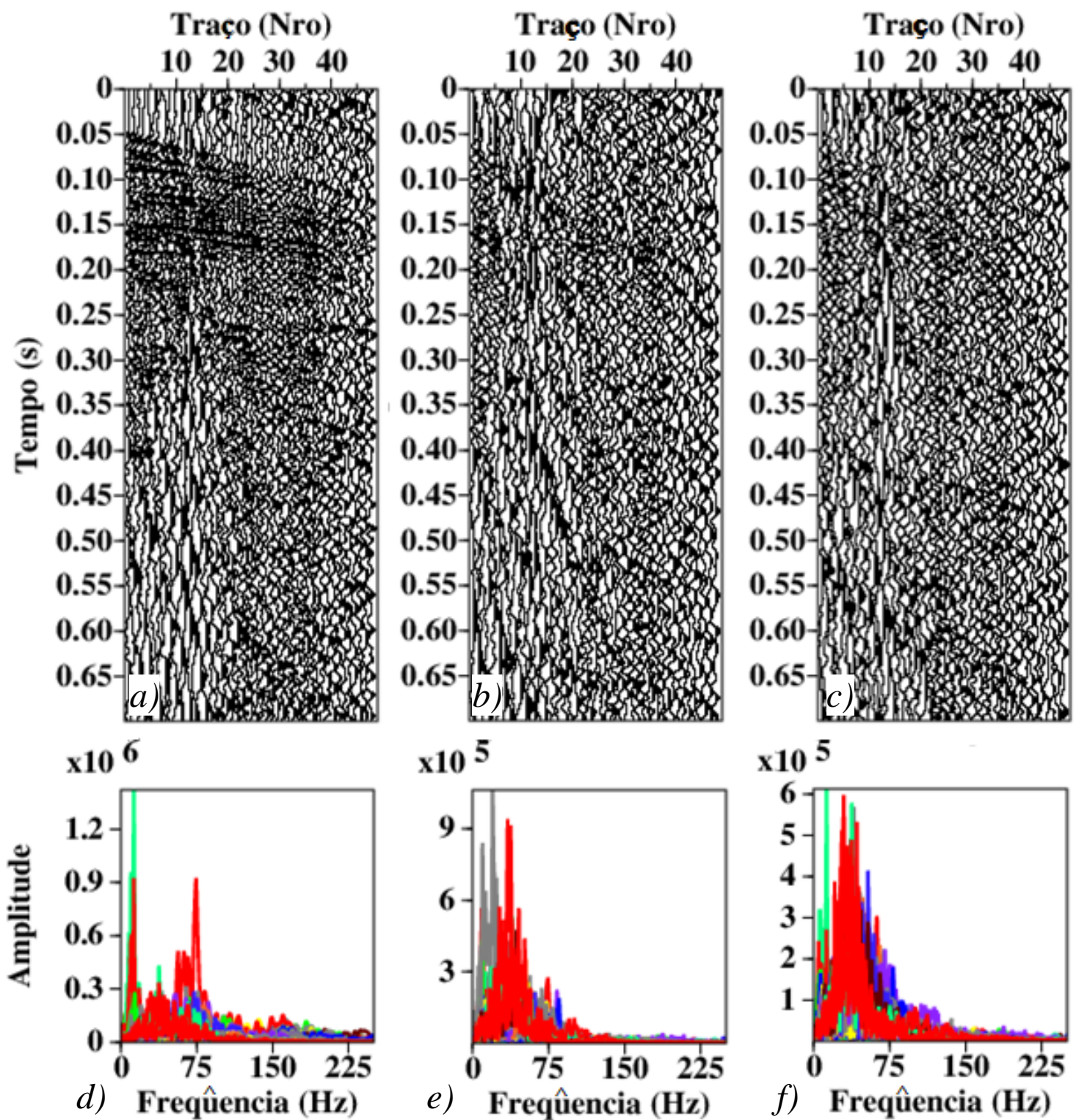

Figura 8.3.3: FLDR 204. Conjuntos de tiro das componentes a) vertical; b) horizontal radial; c) horizontal transversal e seus respectivos espectros de amplitude d), e) e f).
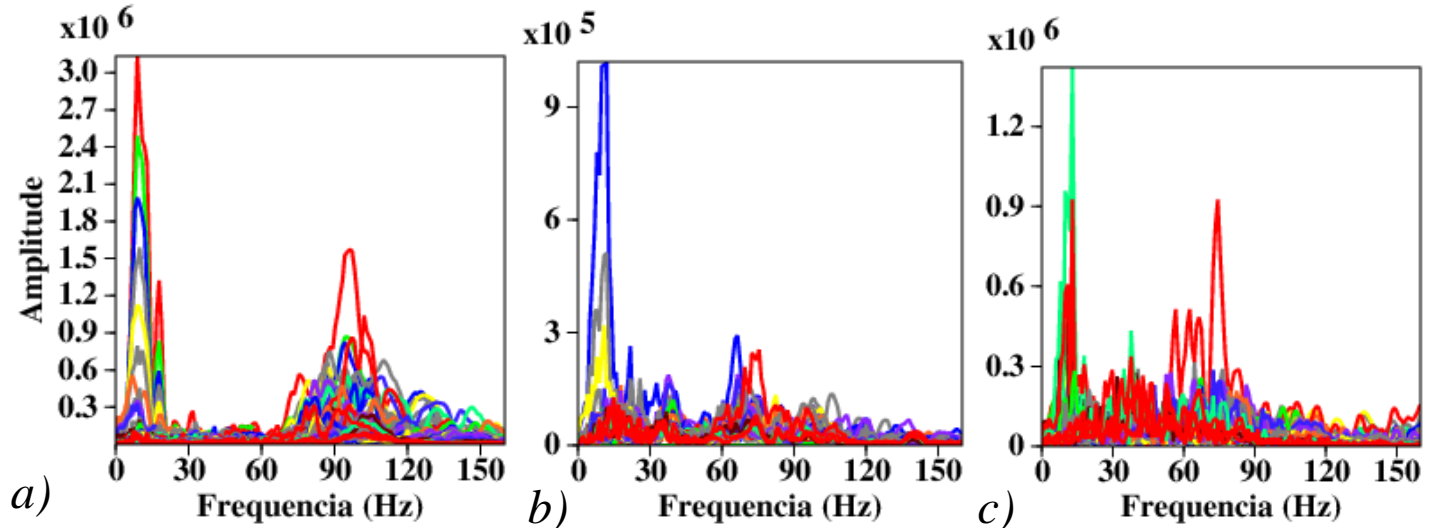

Figura 8.3.4: Espectros de amplitude das componentes verticais dos tiros FLDR 108 (a), FLDR 156 (b) e FLDR 204 (c) na faixa de frequências 0-160 Hz. 


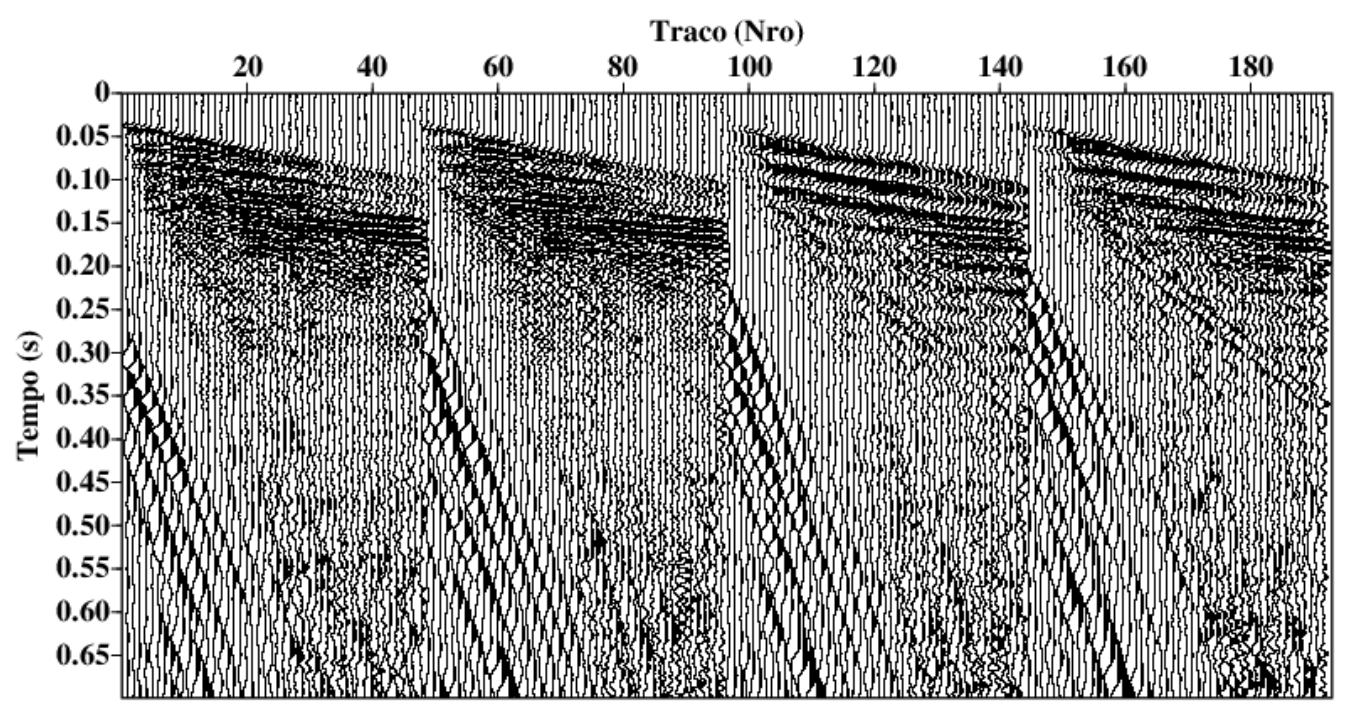

Figura 8.3.5: Sismogramas das componentes verticais correspondentes aos conjuntos de tiros FLDR 122-123-124-125.

\subsection{Aplicação de filtro passa-banda}

Se analisou a janela ótima para a aplicação de filtro passa-banda (PB) na componente vertical dos conjuntos de tiro e seções empilhadas, assim como os efeitos de aplicação de filtro ao dado com ganho ou sem ganho. Foi escolhida a janela para o filtro PB de $20 \mathrm{~Hz}$, $25 \mathrm{~Hz}, 150 \mathrm{~Hz}$ e $165 \mathrm{~Hz}$. A equalização do dado foi realizada mediante uso do comando 'sugain' do SU, através da rotina PBAL (balanceamento das energias através da divisão de cada valor de amplitude pela média quadrática das amplitudes). Para análise comparativa dos resultados de aplicação de filtro na componente vertical são apresentadas as seções empilhadas dos dados não filtrados (Figura 8.4.1), dados sem ganho filtrados (Figura 8.4.2) e dados com ganho filtrados (Figura 8.4.4), além das diferenças das seções empilhadas do dado original com dado filtrado (Figuras 8.4.3 e 8.4.5). A diferença entre o dado original e o dado filtrado nos mostra o ruído, assim como os sinais que foram subtraídos no processo.

No caso das componentes horizontais se aplicou o filtro com os mesmos parâmetros determinados para a componente vertical. O resultado deste processo se mostra nas Figuras 8.4.6 e 8.4.7. Na Figura 8.4.6 se mostra a seção empilhada nos receptores, e na Figura 8.4.7 se mostra a seção empilhada nos conjuntos ACCP, considerando Vp/Vs=3. 


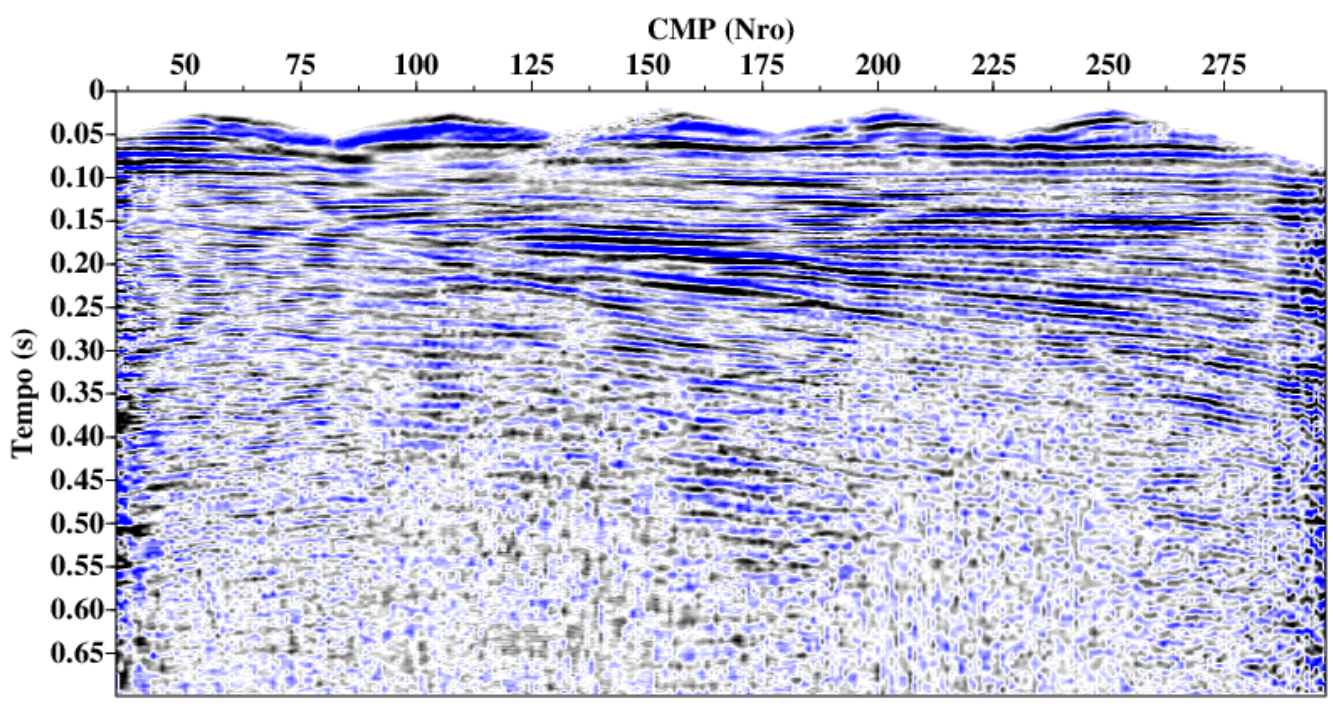

Figura 8.4.1: Seção de dados empilhados sem filtrar. Foi aplicado o ganho para a visualização $(P B A L)$

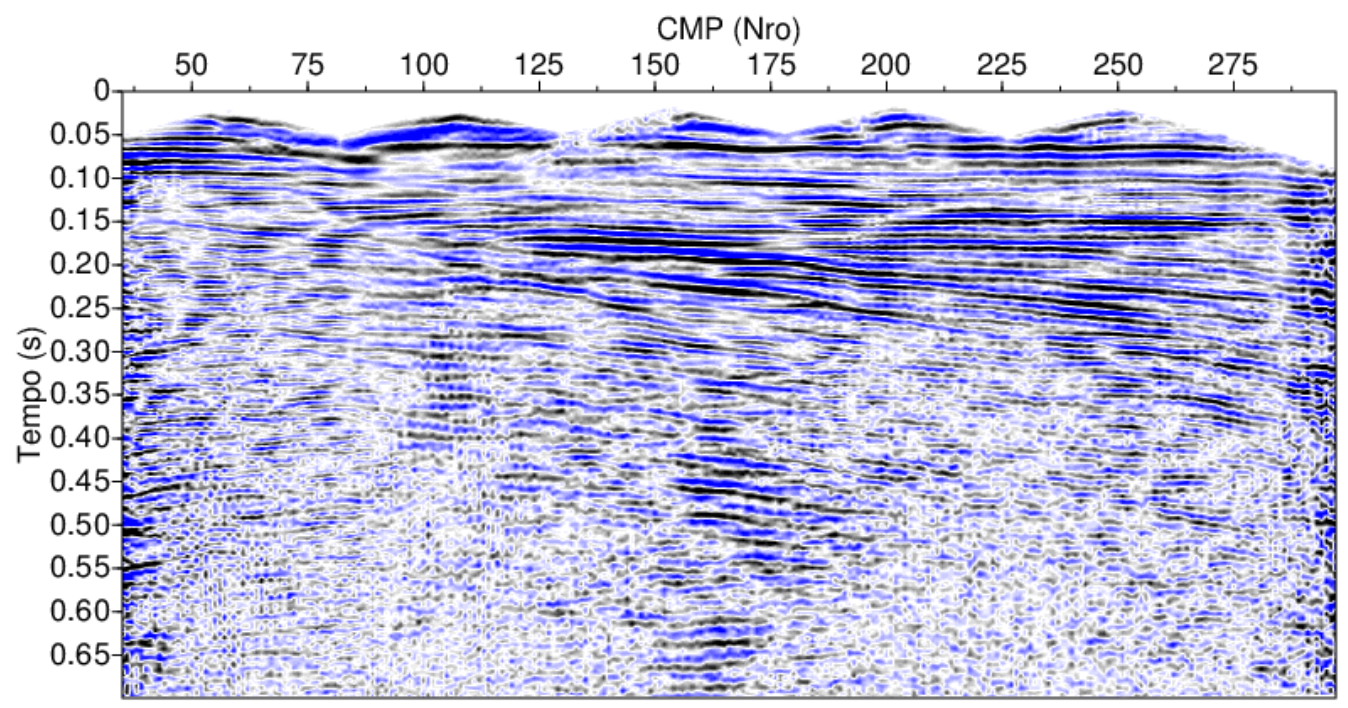

Figura 8.4.2: Seção de dados empilhados com PB aplicado ao dado sem ganho. Foi aplicado o ganho para a visualização (PBAL) 


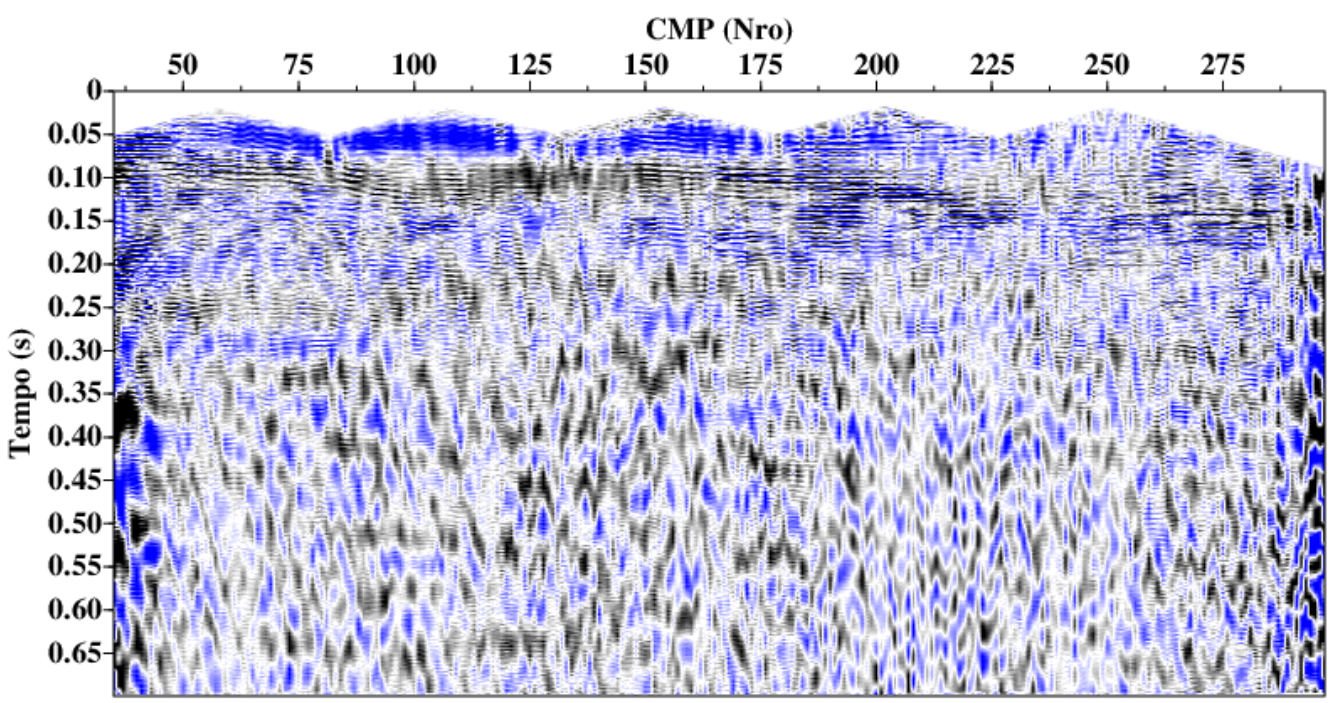

Figura 8.4.3: Imagem da diferença entre seções empilhadas dos dados sem filtrar e dados filtrados com PB mas sem aplicação de ganho. Foi aplicado ganho para a visualização (PBAL)

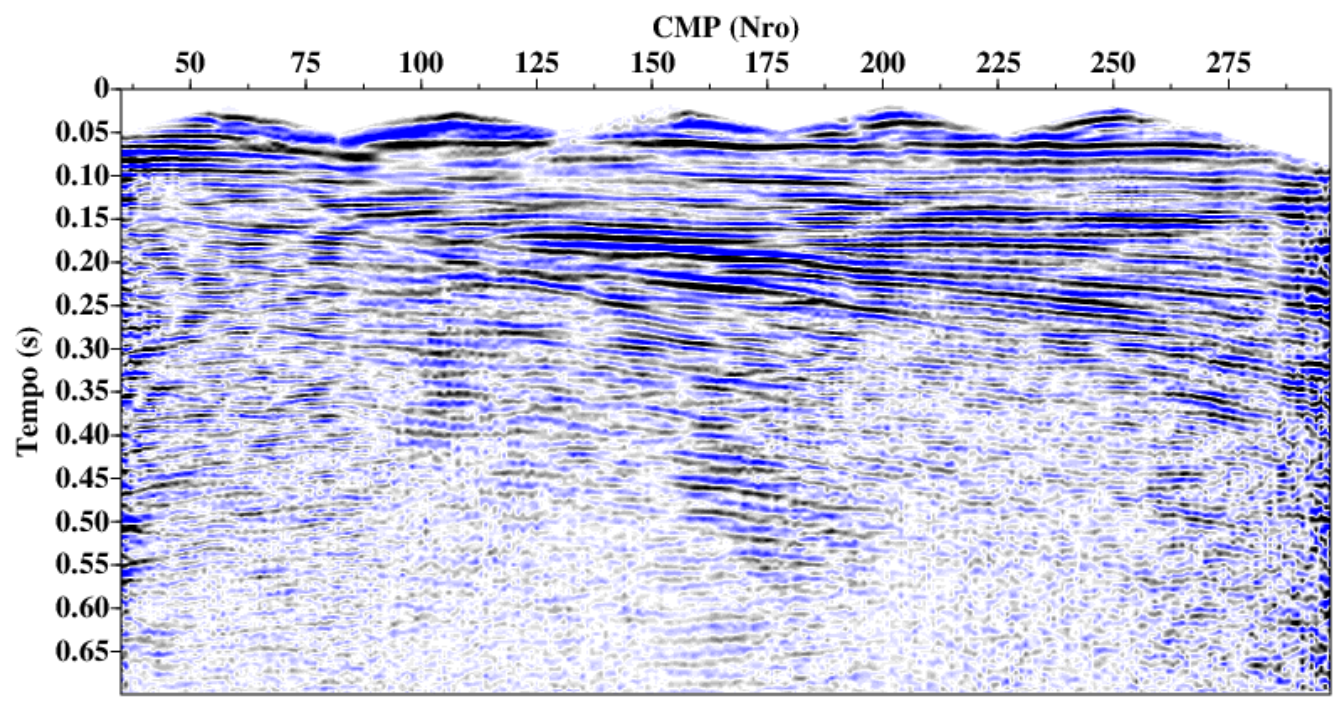

Figura 8.4.4: Seção de dados empilhados com PB aplicado ao dado com ganho (PBAL). 


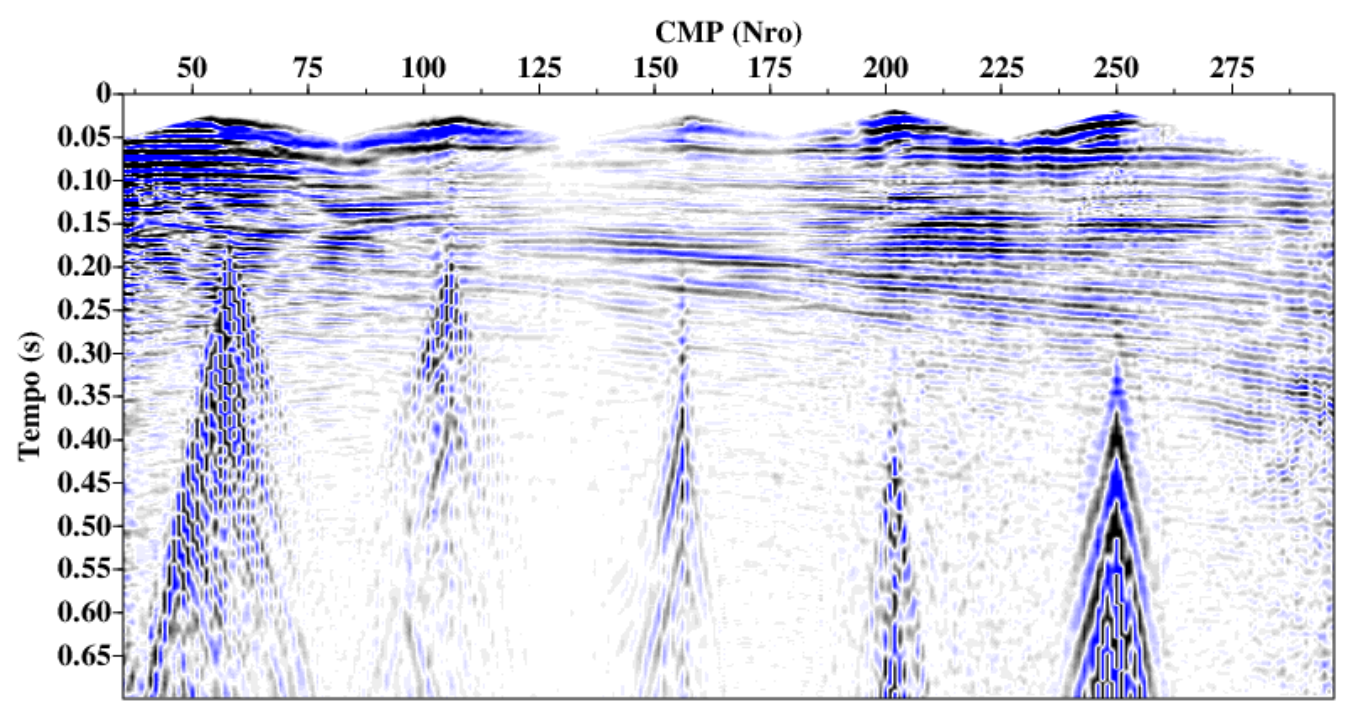

Figura 8.4.5: Imagem da diferença entre as seções empilhadas dos dados sem filtrar e dados filtrados com PB e com ganho de equalização (PBAL).

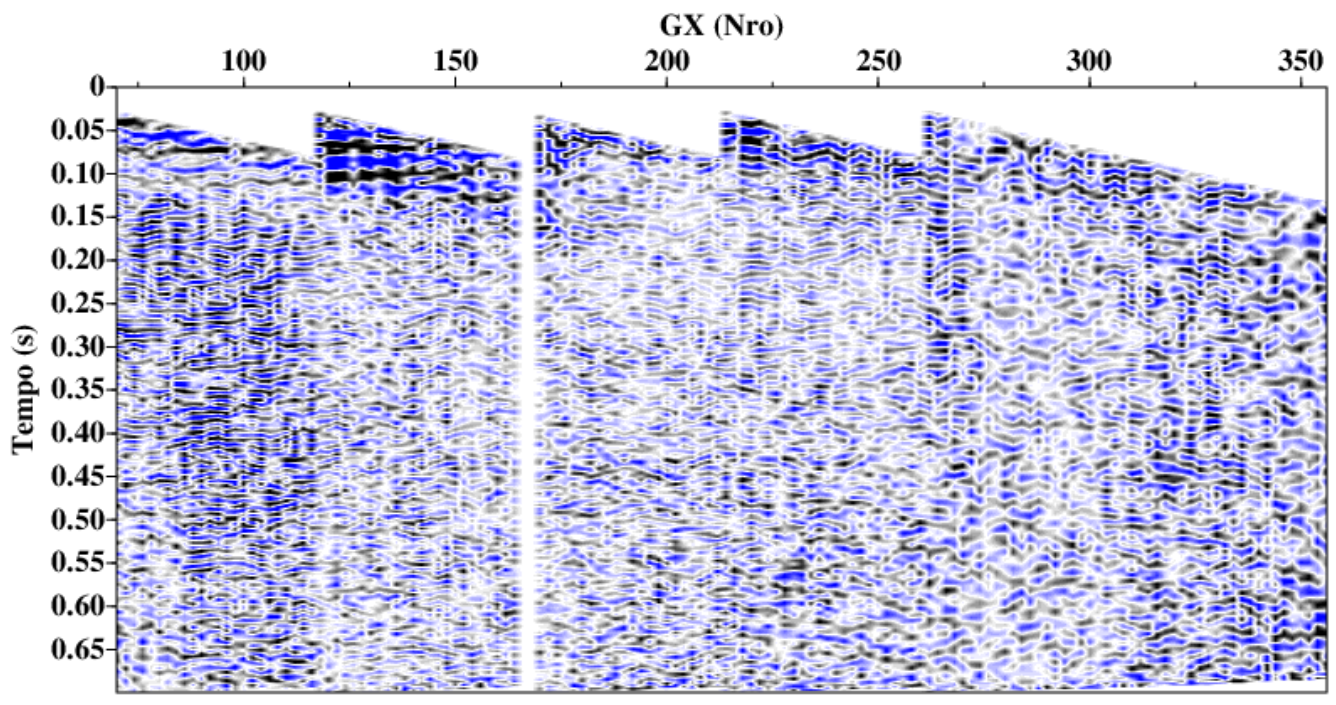

Figura 8.4.6: Componente horizontal radial. Seção empilhada sobre o receptor comum com PB aplicado ao dado com ganho (ganho AGC com janela de 0,5s). 


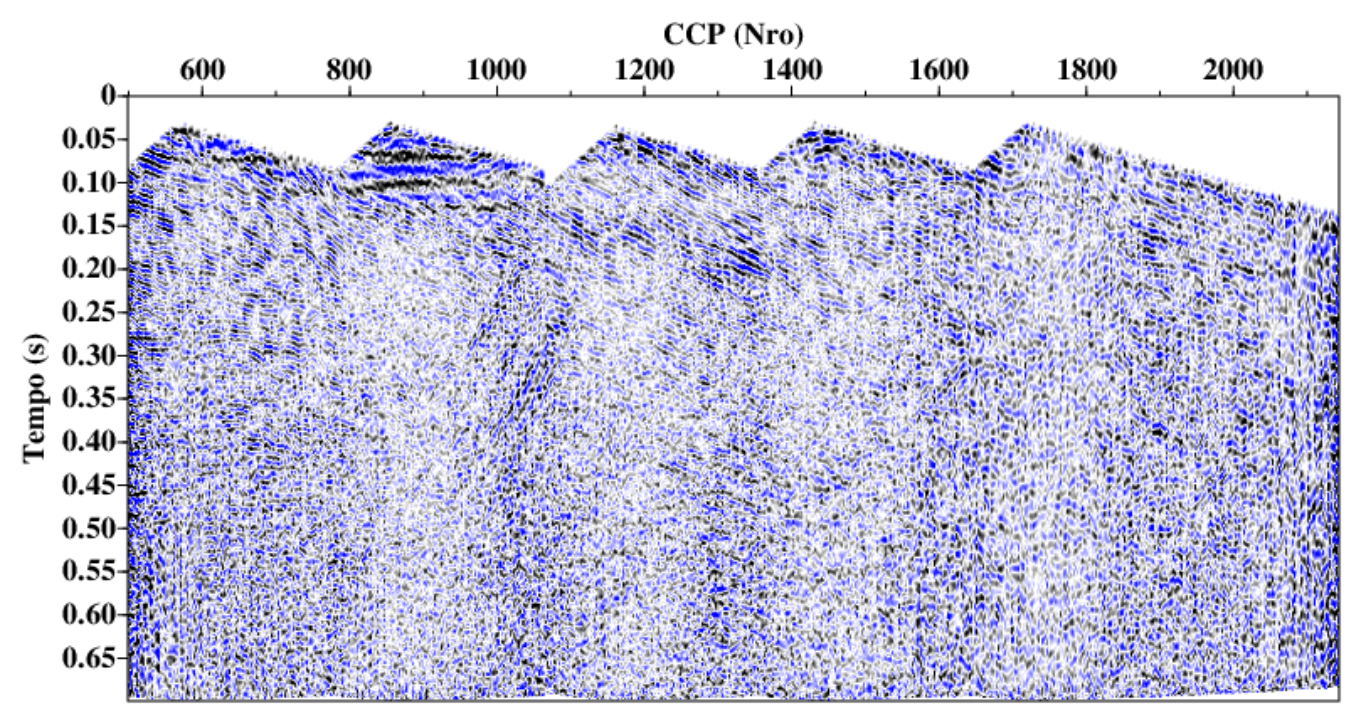

Figura 8.4.7: Componente horizontal radial. Seção empilhada no ACCP (Vp/Vs=3) com PB aplicado ao dado com ganho (ganho AGC com janela de 0,5 s).

Nas seções correspondentes à componente vertical se observa que o filtro PB aplicado aos dados sem ganho extraem parte do ruído de alta e baixa frequências sem prejudicar significantemente o sinal de interesse (Figuras 8.4.2 e 8.4.3). O filtro aplicado ao dado com ganho (Figuras 8.4.4 e 8.4.5) extrai maior porcentagem do groundroll, mas também extrai uma parte notável do sinal. Se conclui, neste caso, que é conveniente a aplicação de filtro PB $(\mathrm{f}=20 \mathrm{~Hz}, 25 \mathrm{~Hz}, 150 \mathrm{~Hz}, 165 \mathrm{~Hz})$ ao dado sem a aplicação de ganho.

Nas seções da componente radial (Figuras 8.4.6 e 8.4.7) se observa a energia das ondas PP, mas não se observa a presença das ondas convertidas.

\subsection{Aplicação de filtro F-K}

Na Figura 8.5.1 são apresentados os espectros f-k das três componentes do sinal, vertical, radial e transversal de um dos conjuntos de tiro do levantamento (FLDR 156). Na componente vertical (Figura 8.5.1 a) o sinal é observado próximo à vertical $(\mathrm{k} \approx 0$ até aproximadamente a frequência de $125 \mathrm{~Hz}$ ), os ruídos de baixa frequência se observam na faixa entre $0 \mathrm{~Hz}$ e $25 \mathrm{~Hz}$, e também se observa um ruído monofrequêncial próximo a $180 \mathrm{~Hz}$. A maior parte do conteúdo de ruído foi eliminado usando o filtro passa-banda. No domínio f-k os sismogramas de tiro das componentes horizontais não mostram presença de sinal de interesse, não obstante, a componente radial mostra um ruído coerente de baixa "velocidade" (Figura 8.5.1 b, c). 


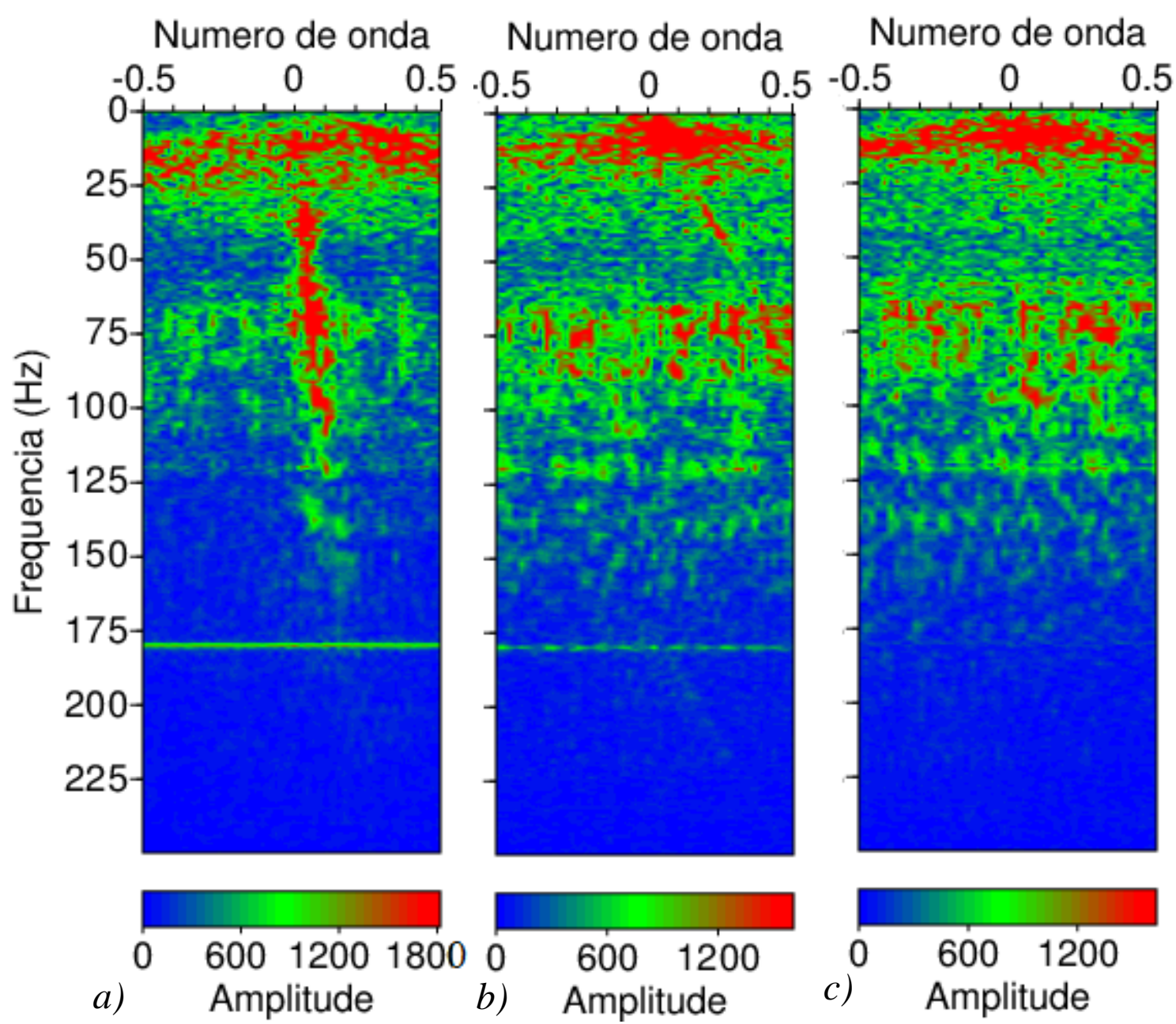

Figura 8.5.1: Espectros f-k de sismogramas de tiro (FLDR156) das componentes a) vertical; $b$ ) horizontal radial e c) horizontal transversal.

As Figuras 8.5.2 e 8.5.3 mostram os conjuntos de receptor e conjuntos ACCP $(\mathrm{Vp} / \mathrm{Vs}=3)$ da componente horizontal radial com seus respectivos espectros no domínio f-k . No caso de conjuntos de receptor comum (Figura 8.5.2) as reflexões observadas concordam com os tempos e as velocidades das ondas PP (Figura 8.5.2 a), assim como a energia "subvertical" observada no espectro (Figura 8.5.2 b). Tanto no caso de receptor comum como no caso de conjunto de pontos de conversão comum não é possível visualizar as reflexões ou a energia associada às ondas convertidas.

Neste caso, também se experimentou diferentes parâmetros do filtro f-k (inclinações das retas no domínio fk) para os sismogramas da componente vertical, assim como a aplicação do filtro ao dado com ganho e sem ganho (PBAL). Os parâmetros de filtro ótimos encontrados foram inclinações $(\mathrm{k} / \mathrm{f})=-0.004,-0.001,0.001,0.004$ e o bias=0.0025. O parâmetro "bias" no filtro fk do SU é importante para eliminar ou atenuar eventos com falseamento 
espacial. O filtro f-k foi aplicado ao dado previamente filtrado com o filtro PB (com os parâmetros definidos anteriormente). Nas figuras a seguir se observam os resultados na seção empilhada da aplicação do filtro fk ao dado (conjunto de tiro) sem ganho (Figura 8.5.4) e com ganho aplicado (Figura 8.5.6), assim como as respectivas diferenças das seções empilhadas com e sem a aplicação de ganho previamente ao filtro fk (Figuras 8.5.5 e 8.5.7). Dos testes realizados, se observou que os melhores resultados foram obtidos com a aplicação do filtro f-k (inclinações $=-0.004,-0.001,0.001,0.004$ e bias=0.0025) ao dado com prévia aplicação de ganho.

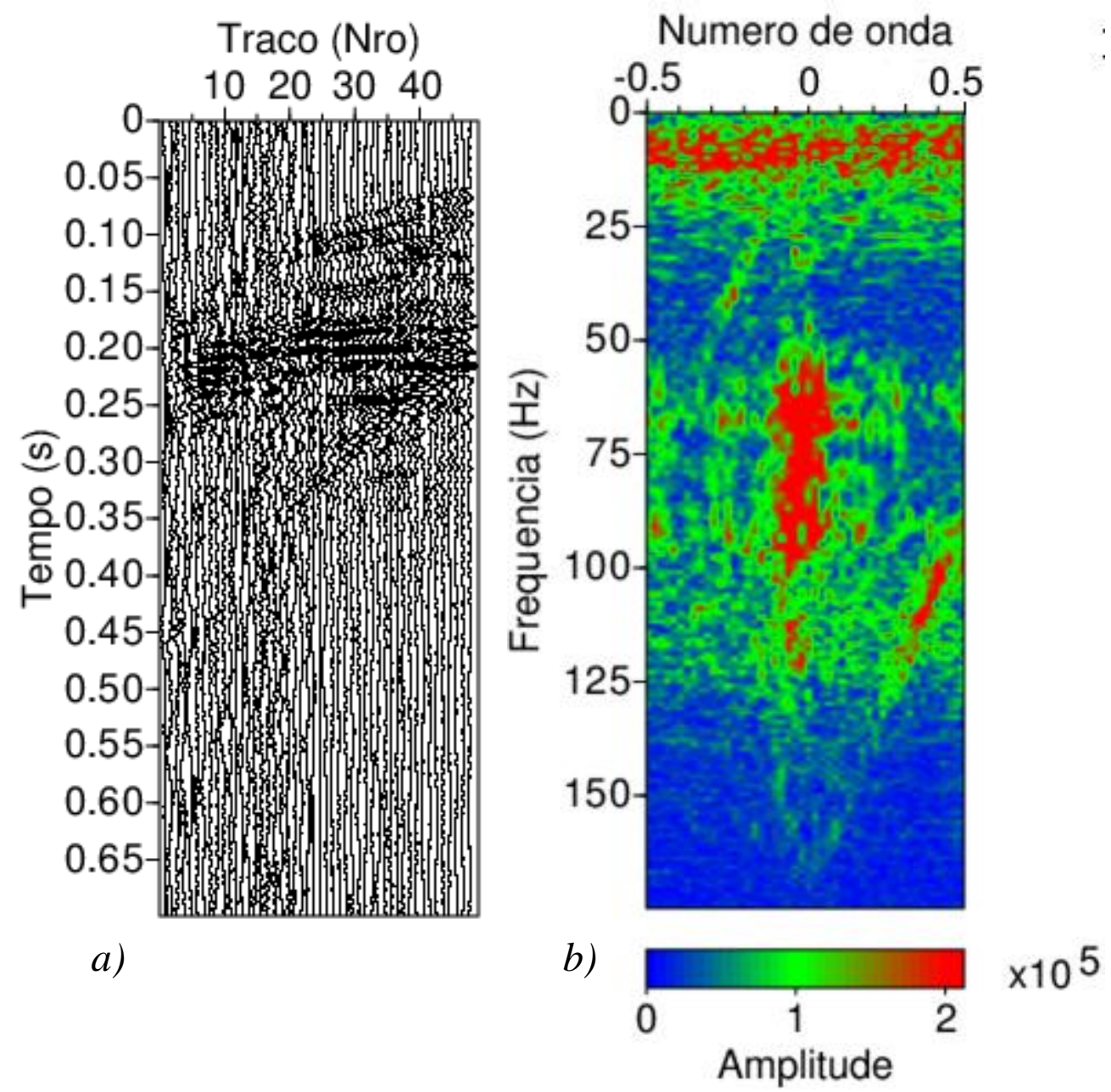

Figura 8.5.2: Receptor ( $g x)$ 200. O espectro do sinal no domínio $f$ - $k$ da componente horizontal radial a) conjunto de receptor comum; b) espectro correspondente no domínio $f$ - $k$. 


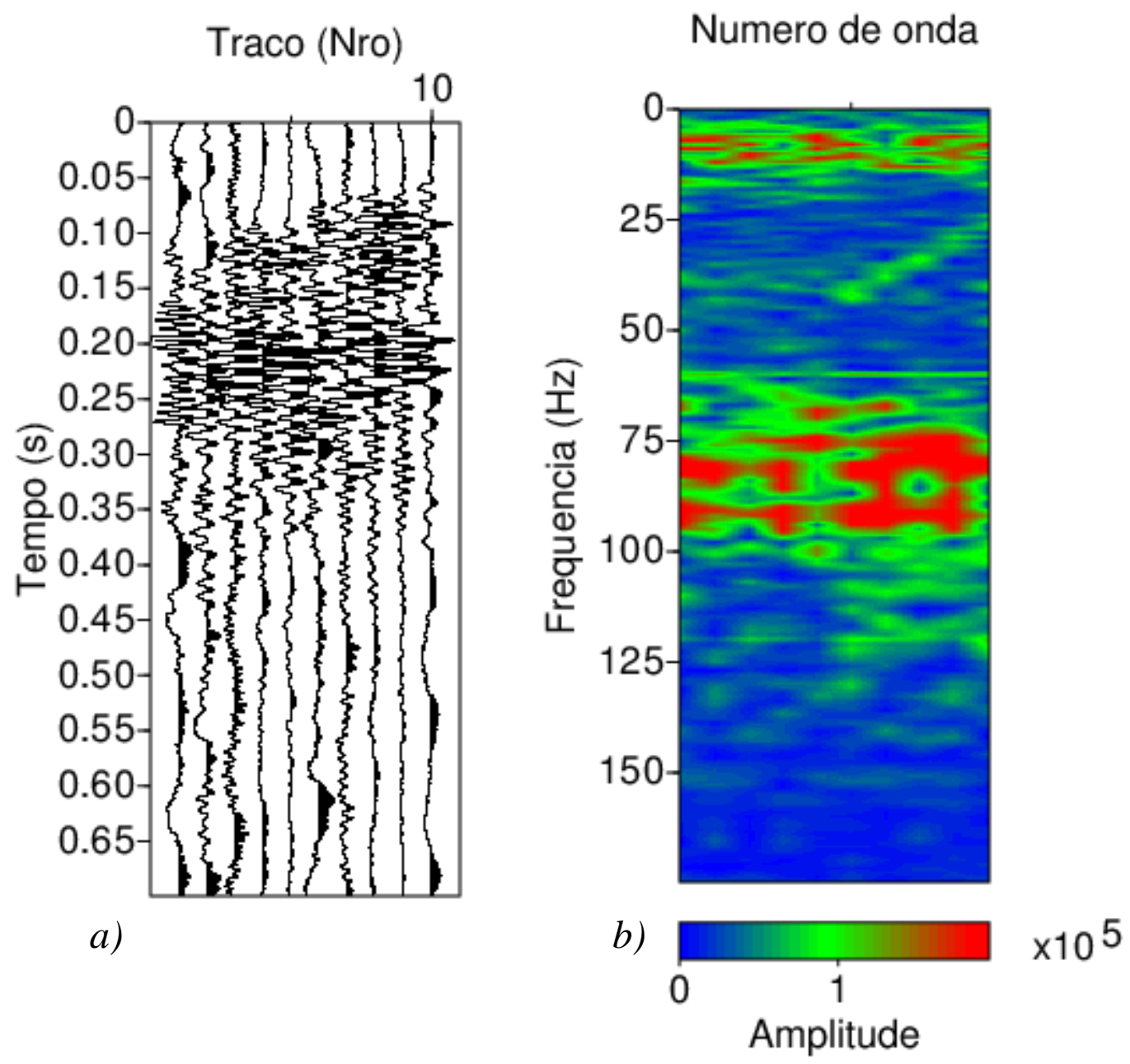

Figura 8.5.3: ACCP 1800. O espectro do sinal no domínio $f$ - $k$ da componente horizontal radial a) conjunto ACCP; $b$ ) espectro correspondente no domínio $f-k$

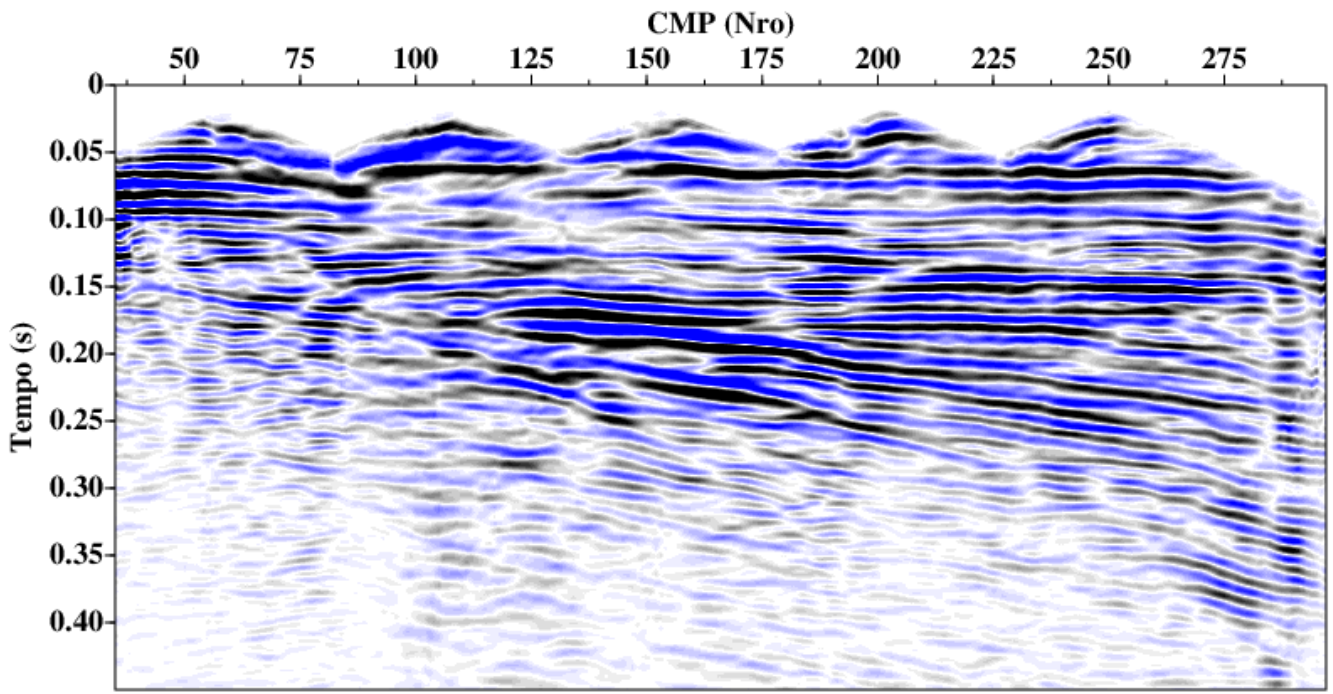

Figura 8.5.4: Seção empilhada de dados com filtro FK aplicado ao dado sem ganho. Parâmetros do filtro aplicado: inclinações=-0.004,-0.001,0.001,0.004. Foi aplicado o ganho para a visualização (PBAL). 


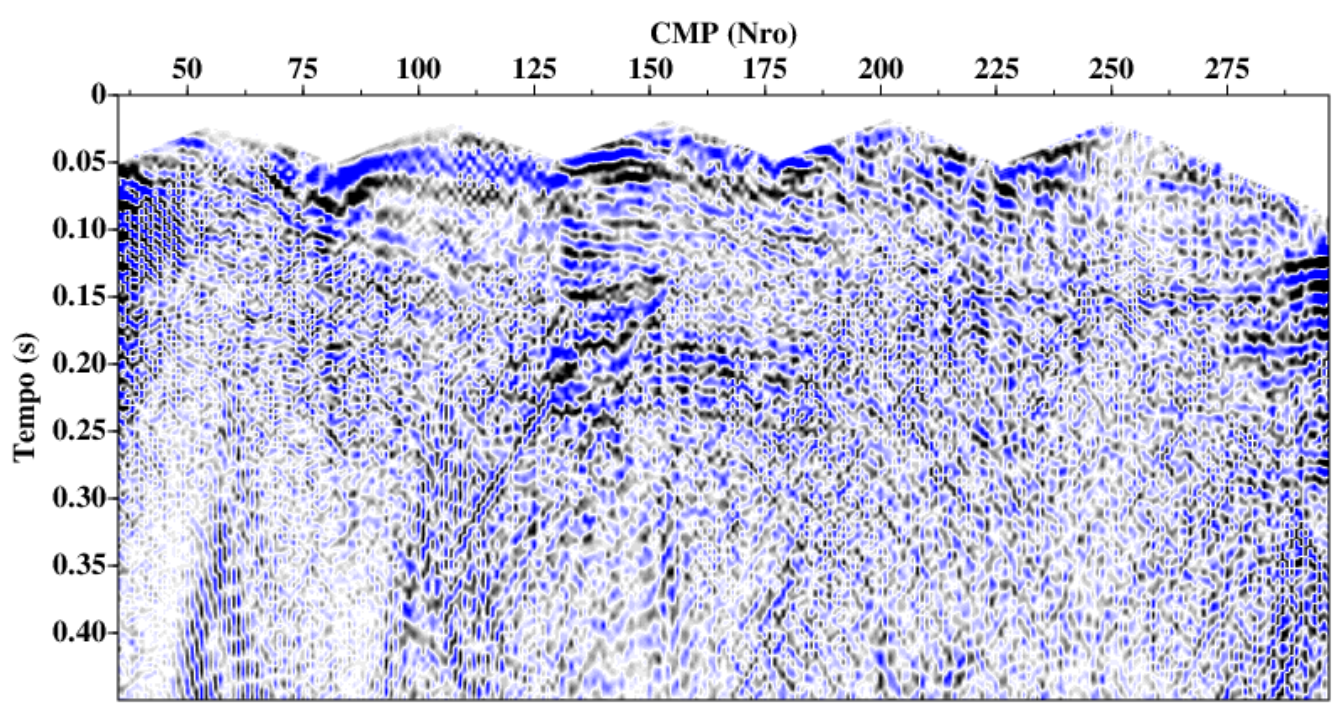

Figura 8.5.5: Imagem da diferença das seções empilhadas dos dados sem filtro FK e com filtro FK aplicado ao dado sem ganho. Parâmetros do filtro aplicado: inclinações=-0.004,-0.001,0.001,0.004 bias $=0.0025$. Foi aplicado o ganho para a visualização $(P B A L)$.

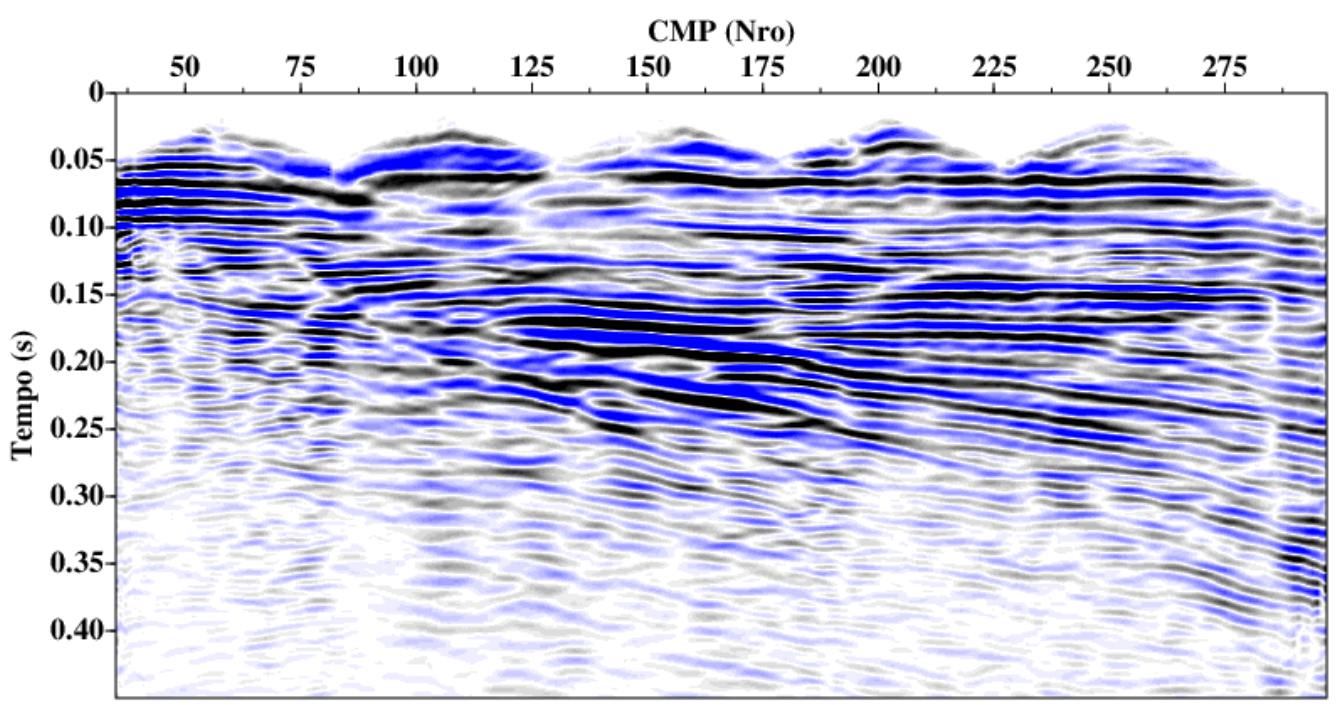

Figura 8.5.6: Seção empilhada dos conjuntos CMP com filtro FK aplicado ao dado com ganho (PBAL). Parâmetros do filtro aplicado: inclinações $=-0.004,-0.001,0.001,0.004$, bias $=0.0025$.

A partir da experiência com a componente vertical, nas componentes horizontais foi aplicado um filtro f-k com os parâmetros inclinações $=-0.005,-0.003,0.003,0.005$, bias $=0.0025$. O ganho usado foi o AGC com janela temporal de 0,5 s. Nas Figuras 8.5.8 e 8.5.9 se mostram as seções empilhadas dos conjuntos de receptor e dos conjuntos ACCP ( $\mathrm{Vp} / \mathrm{Vs}=3)$ da componente radial filtrada, respectivamente. Nenhuma seção mostra presença da onda convertida. 


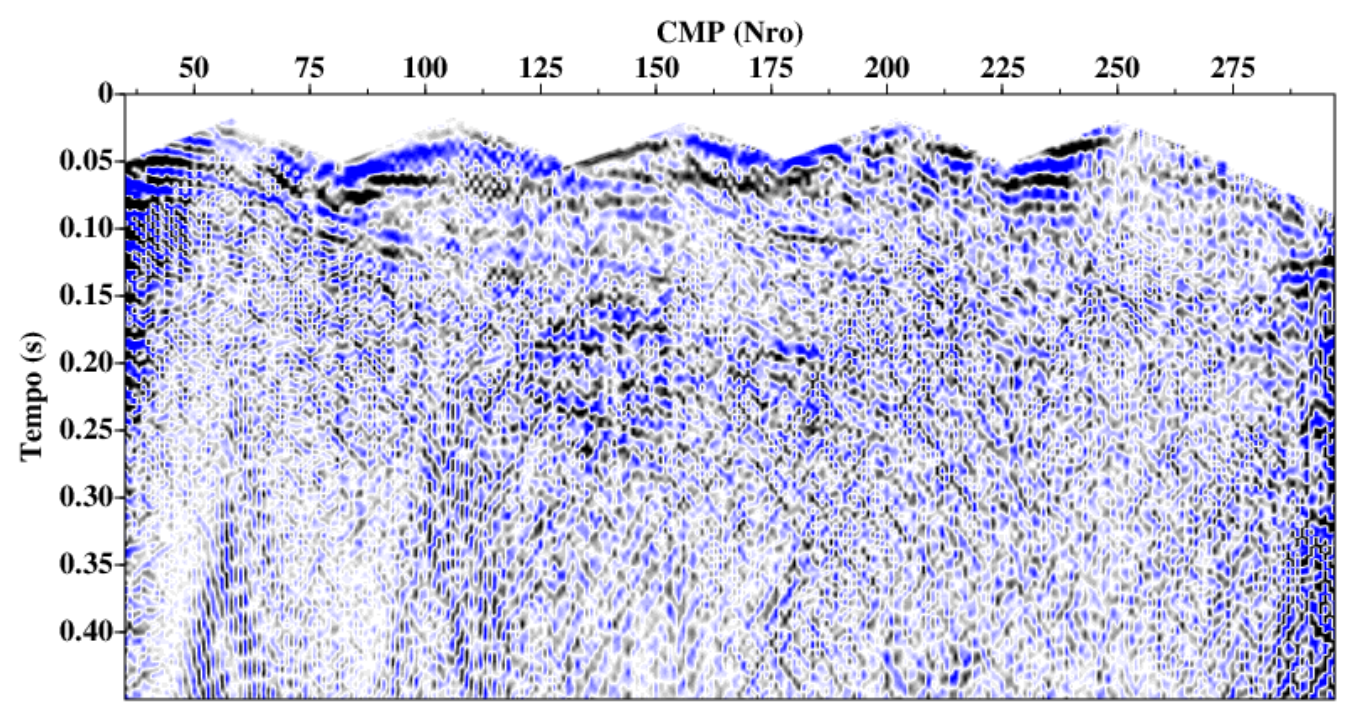

Figura 8.5.7: Imagem da diferença das seções empilhadas dos dados sem filtro FK e com filtro aplicado ao dado com ganho (PBAL). Parâmetros do filtro aplicado: inclinações=-0.004,$0.001,0.001,0.004$, bias $=0.0025$.

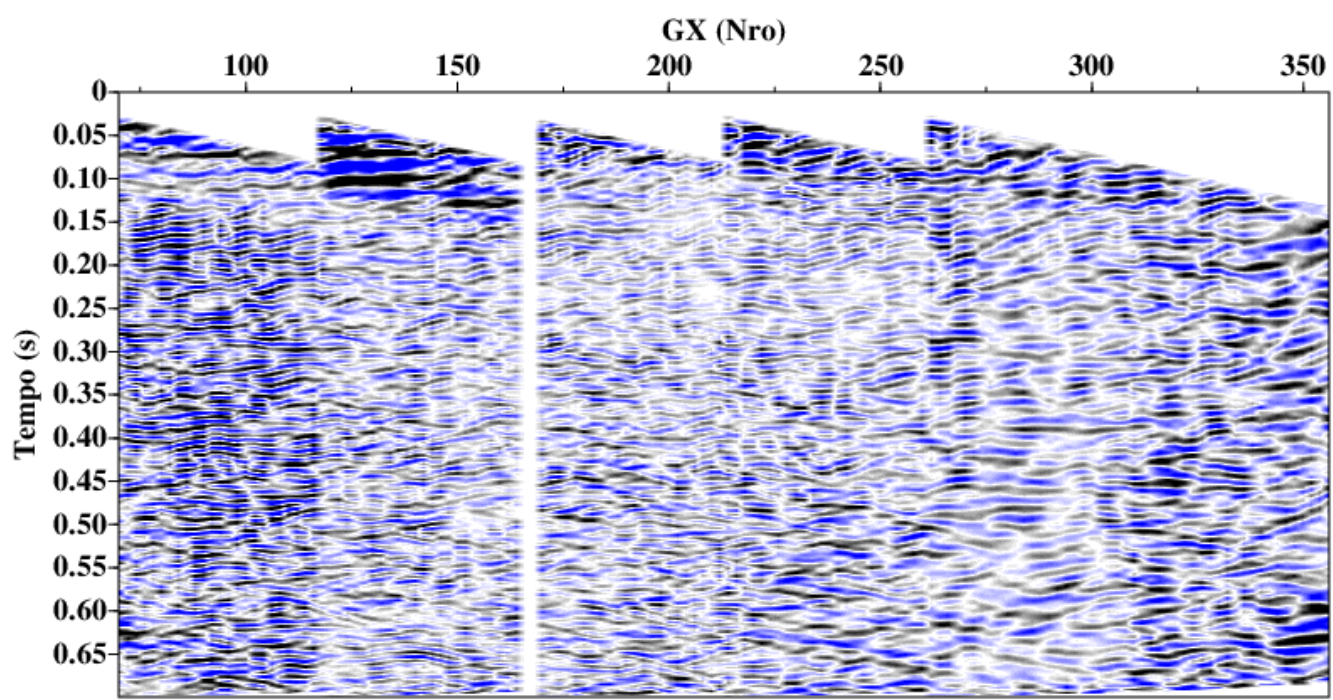

Figura 8.5.8: Seção empilhada da componente radial a partir de conjuntos de receptores com filtro $f$ $k$ aplicado ao dado com ganho (AGC com janela temporal de 0.5s). Parâmetros de filtro aplicado: inclinações $=-0.005,-0.003,0.003,0.005$, bias $=0.0025$. 


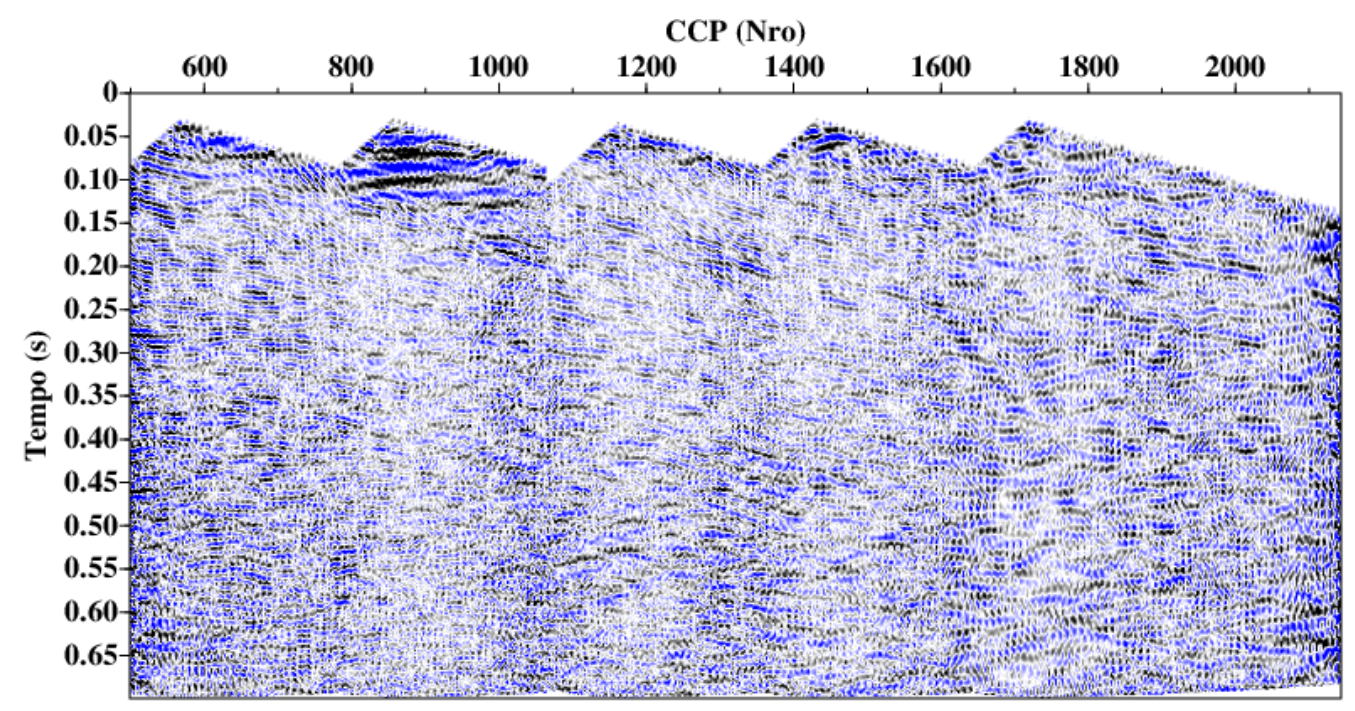

Figura 8.5.9: Seção empilhada da componente radial a partir de conjuntos ACCP com filtro f-k aplicado ao dado com ganho (AGC com janela de 0.5s). Parâmetros de filtro aplicado: inclinações=$0.005,-0.003,0.003,0.005$, bias $=0.0025$.

\subsection{Deconvolução}

Foram experimentados o emprego da deconvolução spiking e deconvolução preditiva visando o aumento no conteúdo das frequências e eliminação de reverberações presentes no dado, respetivamente.

Partindo de autocorrelação dos traços (Figura 8.6.1) para determinar o parâmetro inicial de largura de correlação da ondícula, foram testados diversos valores do mesmo. Para todos os casos a deconvolução spiking resultou ser destrutiva para o dado.

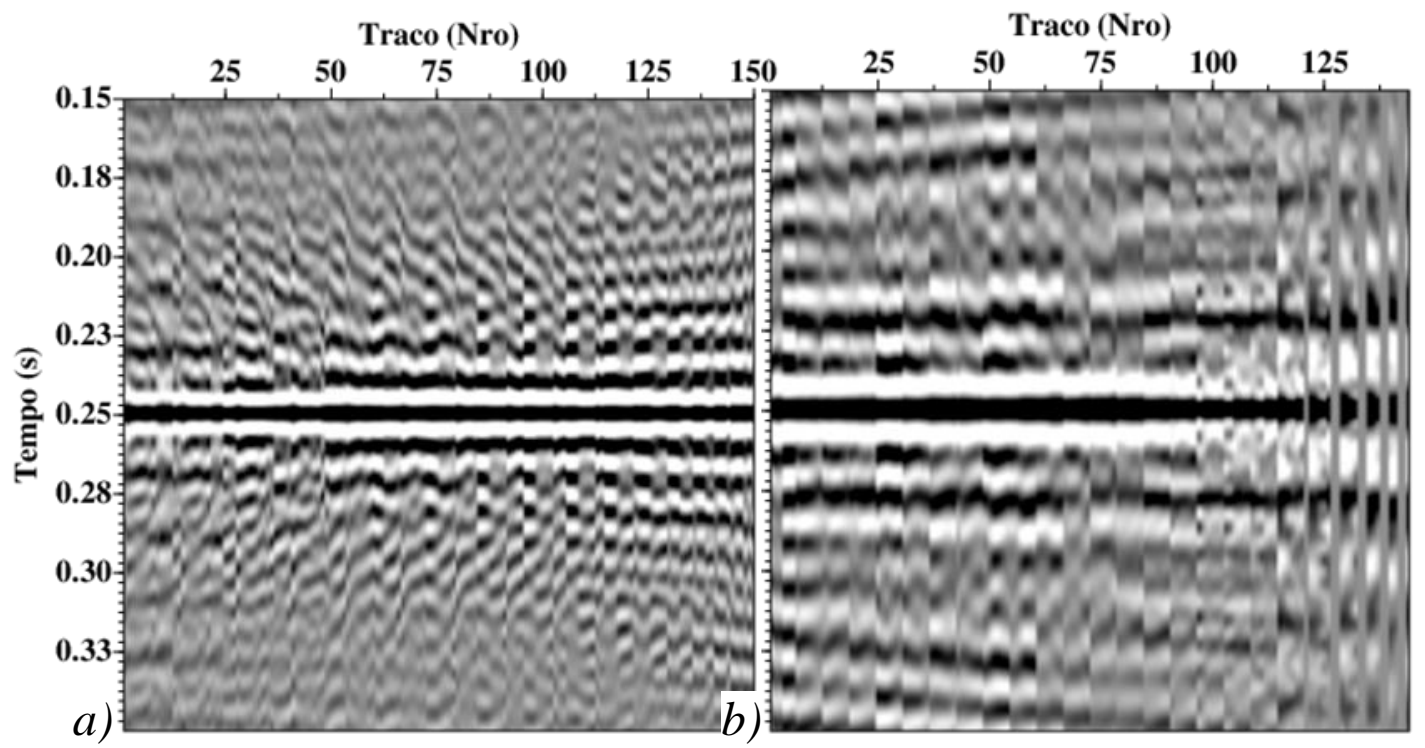

Figura 8.6.1: Autocorrelaçao de traços a) tiros selecionados dos conjuntos correspondentes FLDR 103-123, b) tiros selecionados dos conjuntos correspondentes aos FLDR 124-222. 
Para a deconvolução preditiva foram testados os parâmetros de minlag e maxlag. Esses parâmetros foram determinados partindo dos parâmetros extraídos da correlação dos traços (Figura 8.6.1.)

Se observou uma redução nas reverberações dos tiros associados aos FLDR 103-123 (CDP 1-50) usando deconvolução preditiva com os parâmetros minlag $=0.005 \mathrm{~s}$ e maxlag=0.01s. Para os tiros associados aos FLDR 124-222 se aplicou a deconvolução preditiva utilizando os parâmetros minlag=0.015 e maxlag=0.025. Se mostram na Figura 8.6.2 o resultado da deconvolução aplicada aos conjuntos de tiros FLDR 103-123 com tiros dos FLDR 124-222 sem aplicar a deconvolução, e na Figura 8.6.3 os resultados com a aplicação da deconvolução a todos os dados (conjuntos de tiro) usando os parâmetros citados anteriormente.

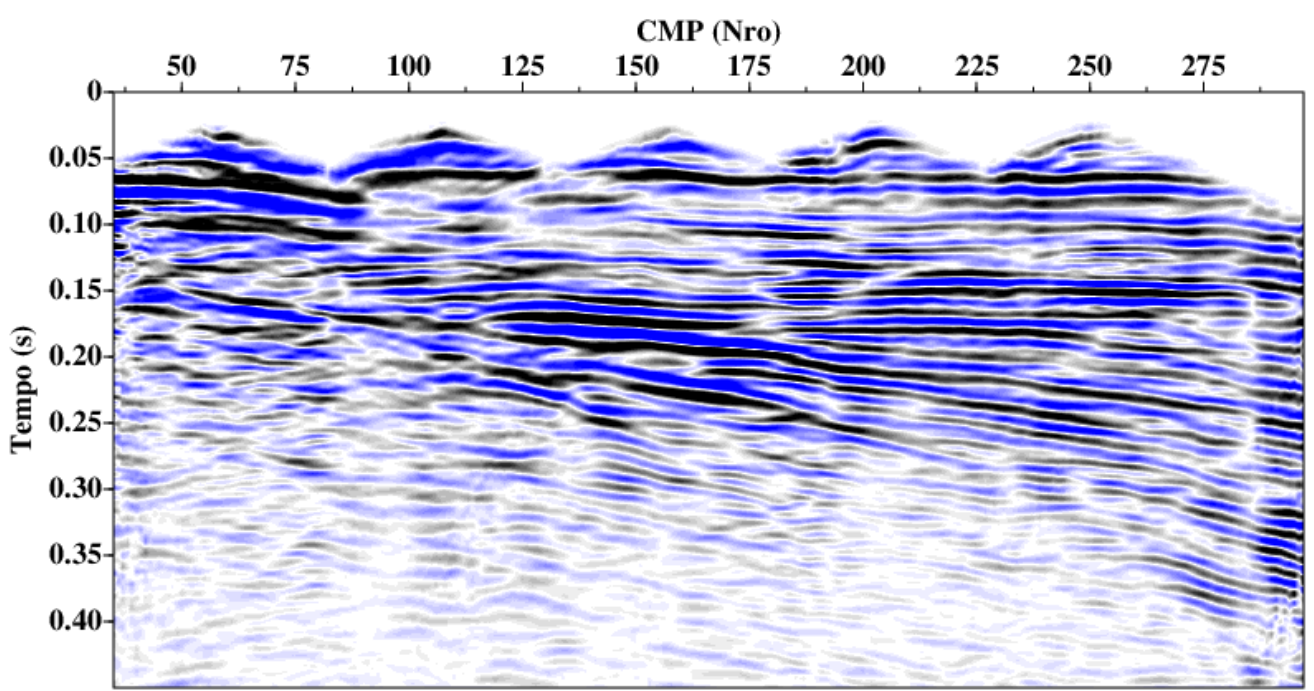

Figura 8.6.2: Seção empilhada em coordenadas $C M P$ ( $x=0$ posição inicial da fonte sísmica) correspondentes aos conjuntos de tiro FLDR 103-123 (com deconvolução) e FLDR 124-222 (sem deconvolução).

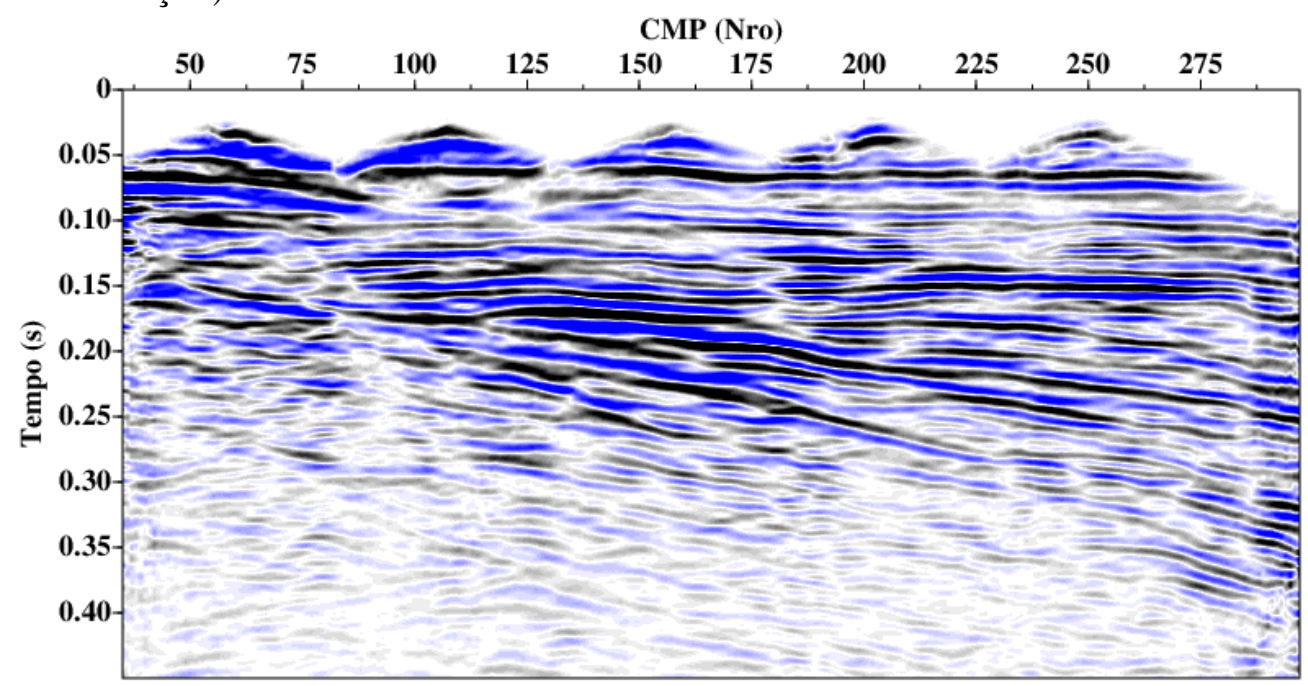

Figura 8.6.3: Seção empilhada em coordenadas CMP ( $x=0$ posição inicial da fonte sísmica). Dados deconvolvidos com parâmetros diferentes para as séries de conjuntos de tiros FLDR 103-123 e FLDR 124-222. 


\subsection{Análise de velocidade}

A análise de velocidade foi realizada usando diferentes métodos. Os dados foram analisados através da função semblance, painel CVS (constant velocity stacking) e painel NMO. O modelo de velocidade foi melhorado de forma iterativa. A melhora notável nas imagens analisadas foi introduzida pela deconvolução preditiva como se observa no exemplo da Figura 8.7.1. As estáticas residuais, assim como aplicação de DMO, não produziram resultados satisfatórios tanto para análise de velocidade, como para o imageamento da estrutura.
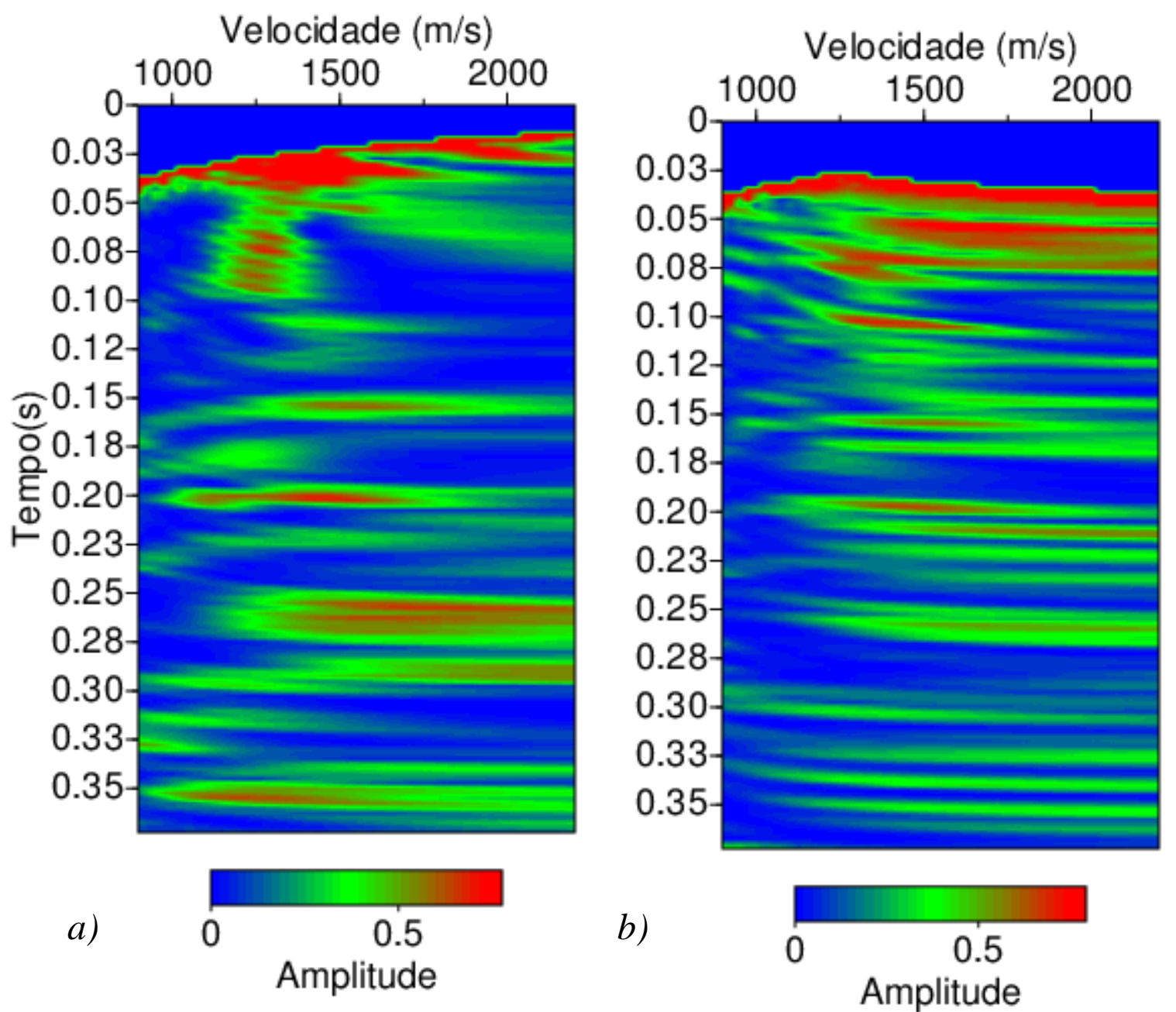

Figura 8.7.1: Gráfico da função semblance do conjunto CMP 50 antes da deconvolução (esquerda) $e$ após a aplicação da deconvolução (direita).

\subsection{Aplicação de filtro Harlan (filtro de coerência)}

Como foi observada uma estrutura complexa que gera difrações, aos dados deconvolvidos foi aplicado o filtro de coerência de Harlan (comando suharlan do SU). Foram utilizados para os parâmetros da transformada tau-p, mínimo e máximo de moveout 
pmin $=400$ e $\operatorname{pmax}=1200$, e para os parâmetros de confiabilidade (reliability) rel $1=0.0001$ rel2=0.0001. O parâmetro de confiabilidade é experimental e determina o que é extraído como parte de sinal. Na Figura 8.8.1 se mostra a seção empilhada com filtro de Harlan aplicado ao dado deconvolvido nos CMP correspondentes aos conjuntos de tiros FLDR 103123 e na Figura 8.8.2 se mostra seção empilhada correspondente de ruído e difrações subtraídas. Na Figura 8.8.3 se mostra A seção empilhada com filtro aplicado aos dados deconvolvidos com parâmetros diferentes para os tiros correspondentes aos FLDR 103-123 e FLDR 124-222. O ruído e difrações extraídas são apresentados na Figura 8.8.4. Como se observa na Figura 8.8.3, o processo melhora a continuidade dos refletores.

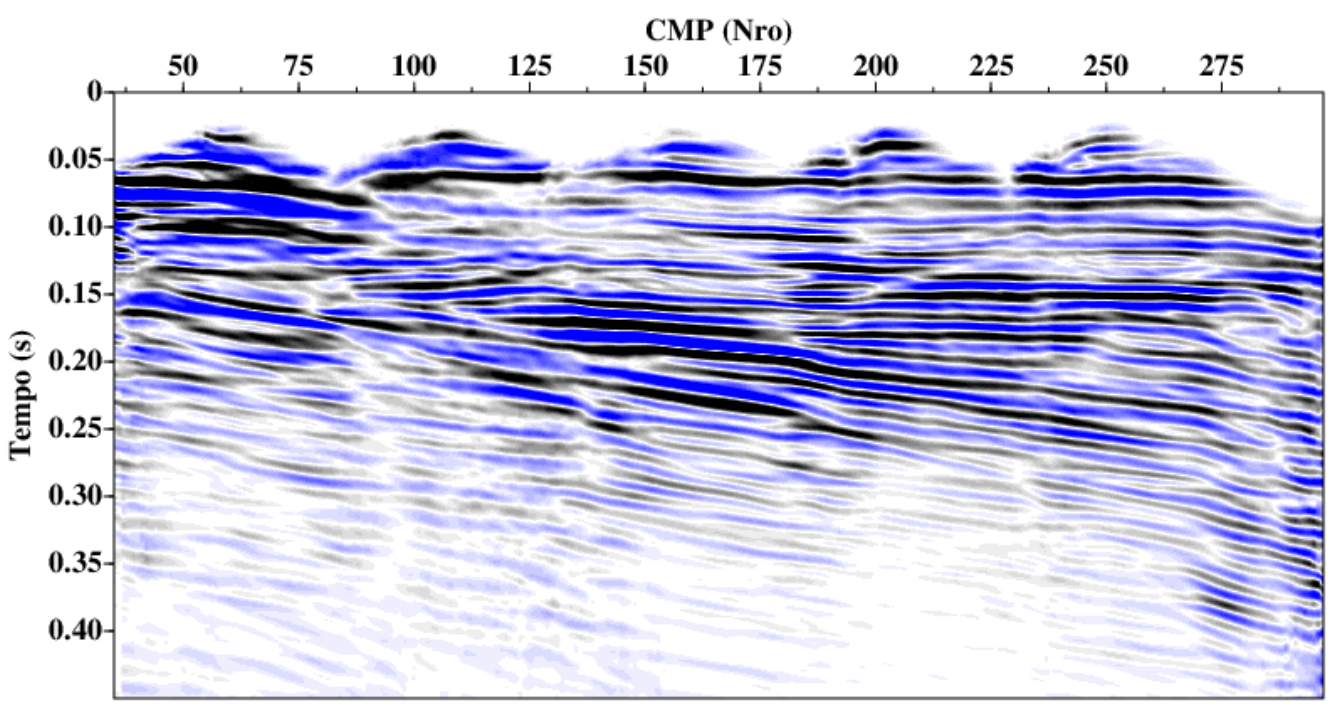

Figura 8.8.1: Seção empilhada com a aplicação do filtro de Harlan nos dados deconvolvidos (cdp correspondentes aos conjuntos de tiros FLDR 103-FLDR 123).

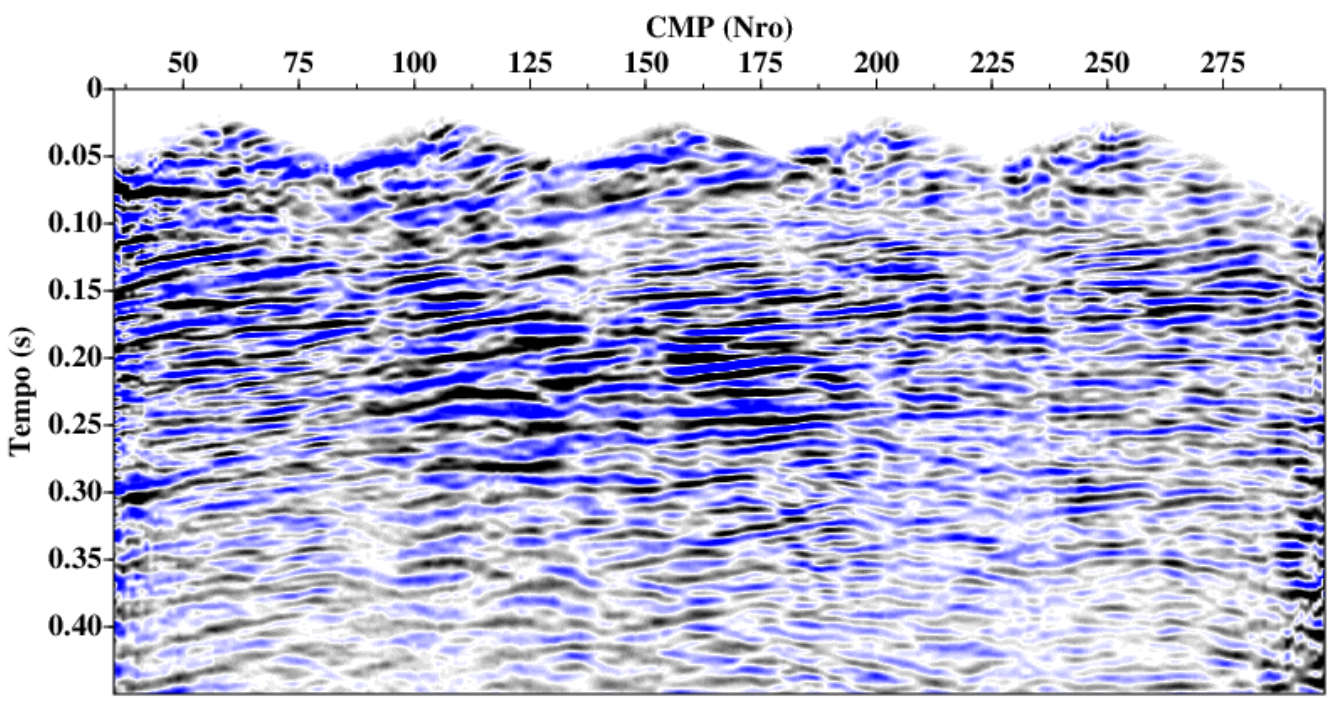

Figura 8.8.2: Imagem da diferença entre as seções empilhadas com e sem a aplicação do filtro de Harlan nos dados deconvolvidos (conjuntos cdp correspondentes aos tiros FLDR 103 - FLDR 123). 


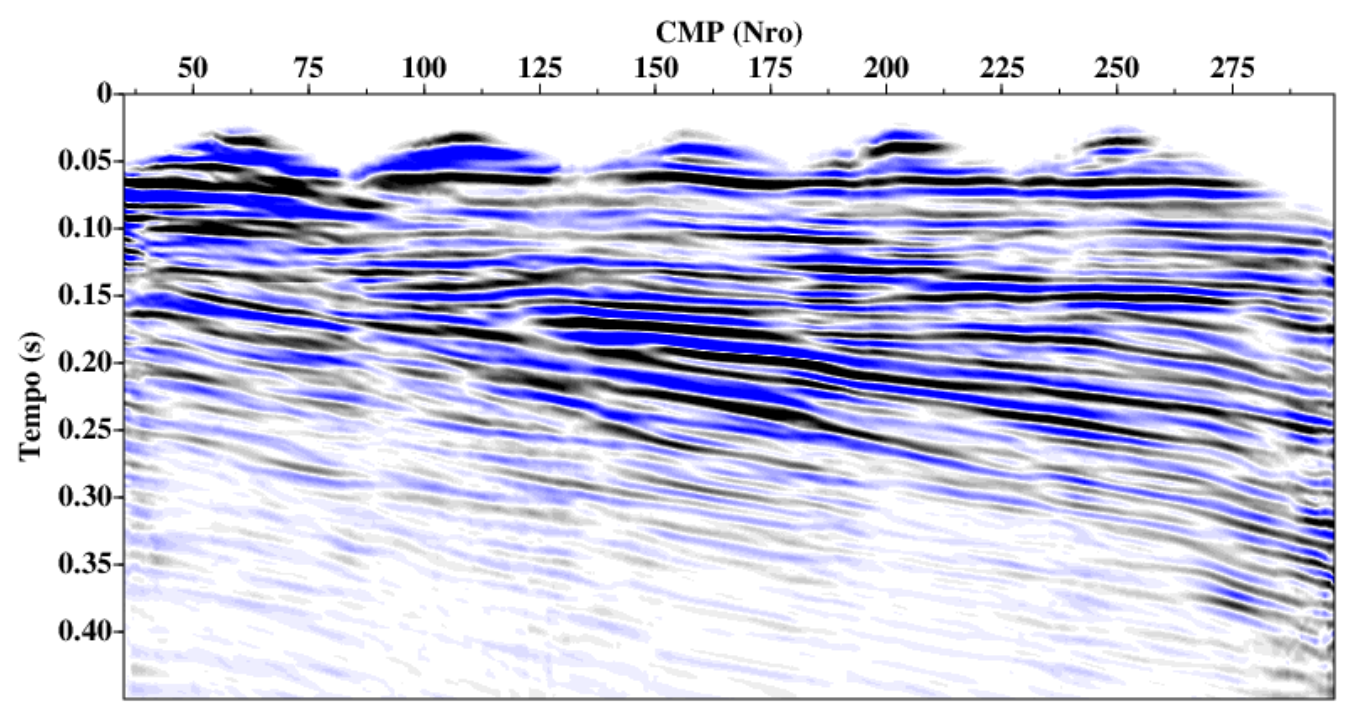

Figura 8.8.3: Seção empilhada com a aplicação do filtro de Harlan nos dados deconvolvidos com parâmetros diferentes para os conjuntos de tiros correspondentes aos FLDR maiores que 123.

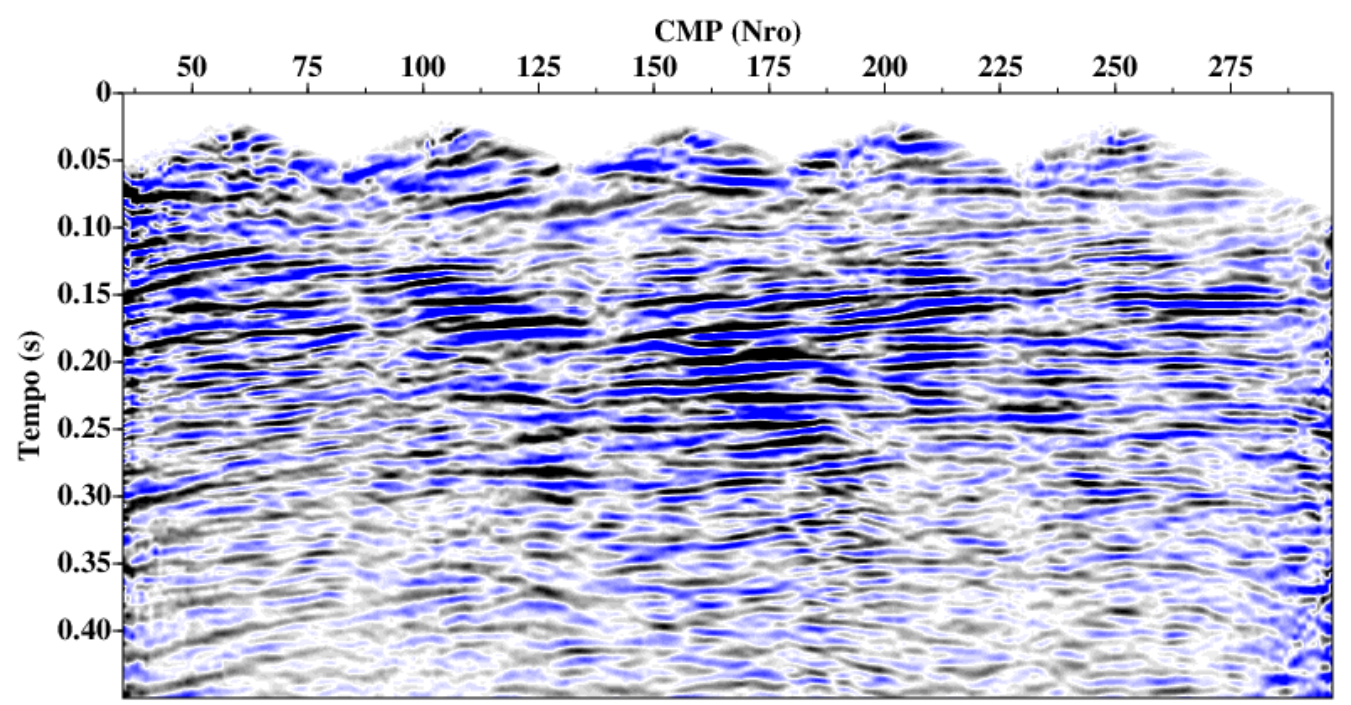

Figura 8.8.4: Imagem da diferença das seções empilhadas com e sem a aplicação do filtro de Harlan nos dados deconvolvidos (com parâmetros diferentes para os tiros correspondentes aos FLDR menores e maiores que FLDR 123). 


\section{Processamento: área USP}

\subsection{Controle de qualidade da geometria e cálculo de ACCP}

O controle de qualidade da geometria introduzida aos dados pode ser realizado mediante a análise do gráfico das posições de tiros e receptores (Figura 9.1.1). Na Figura 9.1.1 é apresentada a geometria da aquisição utilizada nos dados sísmicos da USP. Nela podese observar a disposição de fontes e receptores utilizada nos dados (componentes vertical e horizontais), tendo como origem (estaca $\mathrm{x}=0$ ) a primeira posição de fonte e sendo FLDR (designação do Seismic Unix - original field record number) o número do registro sísmico de campo (conjunto de tiro).

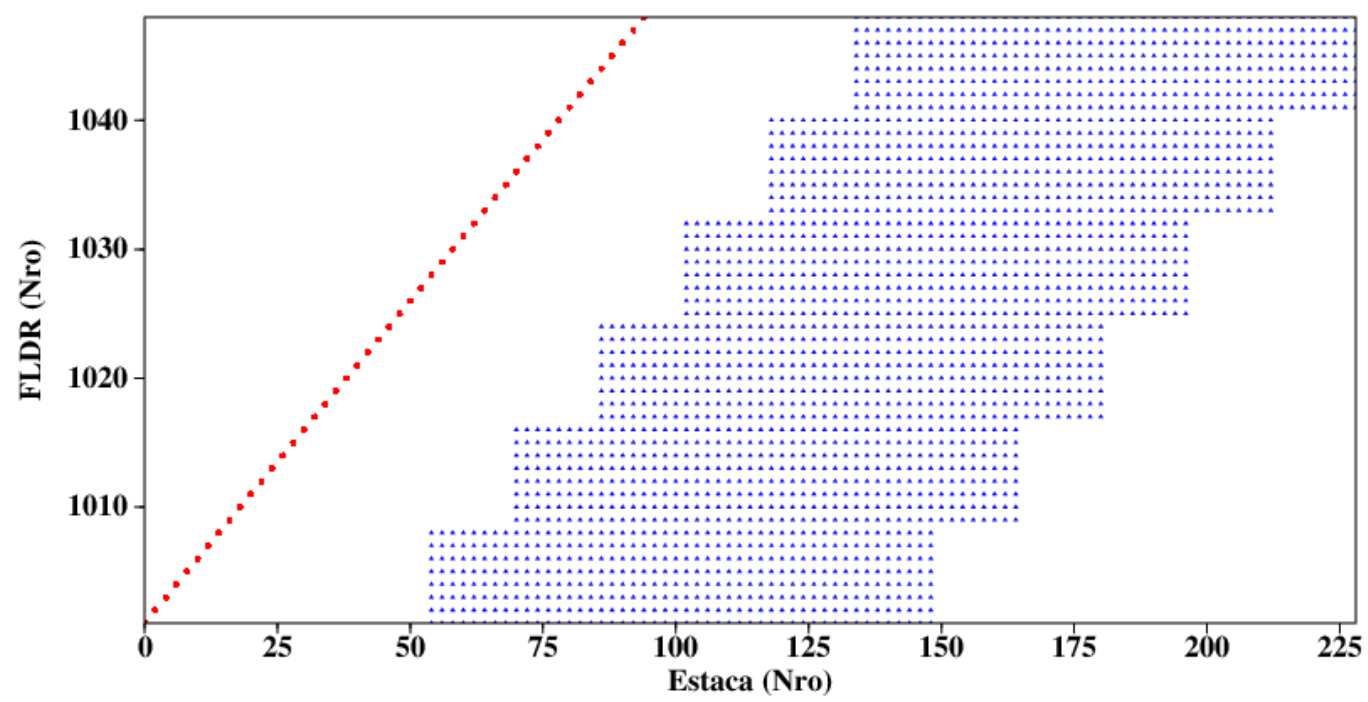

Figura 9.1.1: Geometria de aquisição. A posição das fontes e receptores estão referidas aos números de estacas a partir de zero para o primeiro tiro e os números de tiros estão vinculados aos números de arquivo de aquisição (FLDR). Os pontos vermelhos indicam as posições de fontes e os pontos azuis indicam as posições de receptores.

Na Tabela 9.1.1 se mostram as faixas de alguns valores dos cabeçalhos dos traços sísmicos da componente vertical obtidos usando o comando 'surange' do SU. As componentes são identificadas usando a palavra-chave 'trid', onde trid=12 identifica a componente vertical, trid=14 e trid=13 identificam componentes horizontais radial e transversal respetivamente. O campo do cabeçalho denominado ' $\mathrm{d} 2$ ' foi usado para alocar os valores de ACCP calculados para as componentes horizontais. Para o cálculo do ponto de conversão foi aplicada a Equação 6.3 .4 usando uma razão Vp/Vs constante. $\mathrm{O}$ valor da 
palavra-chave ' $\mathrm{d} 2$ ' assim calculado é inserido no cabeçalho do dado usando o comando 'suchw' do SU.

Tabela 9.1.1 - Faixas dos valores dos cabeçalhos introduzidos aos dados sísmicos (exemplo de componente vertical).

\begin{tabular}{|c|c|c|c|}
\hline \multirow{2}{*}{$\begin{array}{l}\text { Palavra chave } \\
\text { (Seismic } \\
\text { Unix) }\end{array}$} & \multirow[t]{2}{*}{ Descrição } & \multicolumn{2}{|c|}{ Faixa dos valores } \\
\hline & & Mínimo & Máximo/Total \\
\hline traces & Quantidade de traços & & 2304 \\
\hline fldr & Número de arquivo & 1001 & 1049 \\
\hline tracf & Número de traço & 1 & 48 \\
\hline $\operatorname{cdp}$ & Ponto de reflexão & 27 & 161 \\
\hline trid & Componente & 12 & 14 \\
\hline offset & Offset (m) & $40 \mathrm{~m}$ & $148 \mathrm{~m}$ \\
\hline sx & Número de estaca de tiro & 0 & 94 \\
\hline gx & Número de estaca de receptor & 54 & 229 \\
\hline ns & Número de amostras (tempo) & & 2000 \\
\hline $\mathrm{dt}$ & $\begin{array}{l}\text { Período de amostragem (tempo } \\
\text { em microssegundos) }\end{array}$ & & 500 \\
\hline $\mathrm{d} 2$ & Coordenada do conjunto ACCP & 40.5 & 194.5 \\
\hline
\end{tabular}

A Figura 9.1.2 mostra os pontos médios comuns calculados (CMP) para a componente vertical, a Figura 9.1.3 mostra os ACCP (ponto assintótico de conversão comum) calculados considerando Vp/Vs=3 e a Figura 9.1.4 a multiplicidade dos traços resultante.

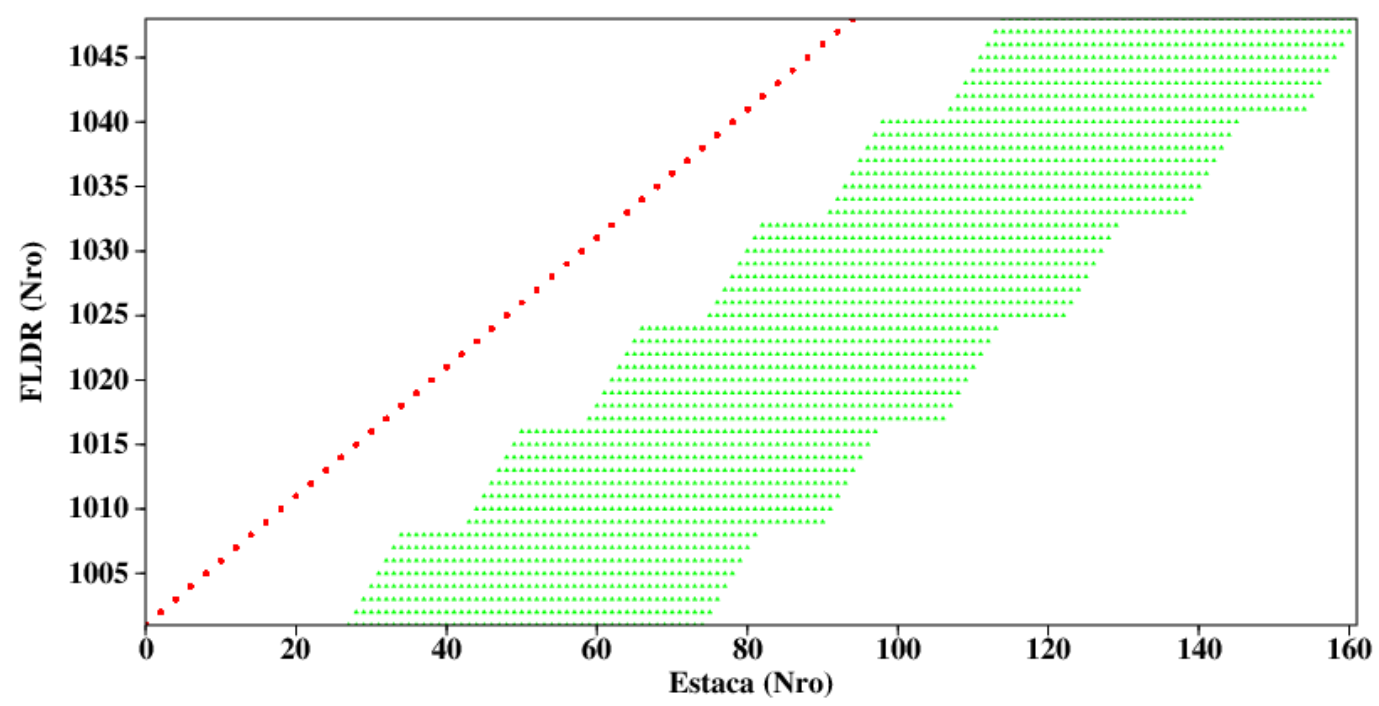

Figura 9.1.2: Geometria de aquisição. A posição das fontes e pontos médios comuns estão referidas aos números de estacas a partir de zero para o primeiro tiro e aos números de arquivo de aquisição (FLDR), que iniciam em 1001. Os pontos vermelhos indicam as posições de fontes e os pontos verdes indicam as posições CMP calculadas. 


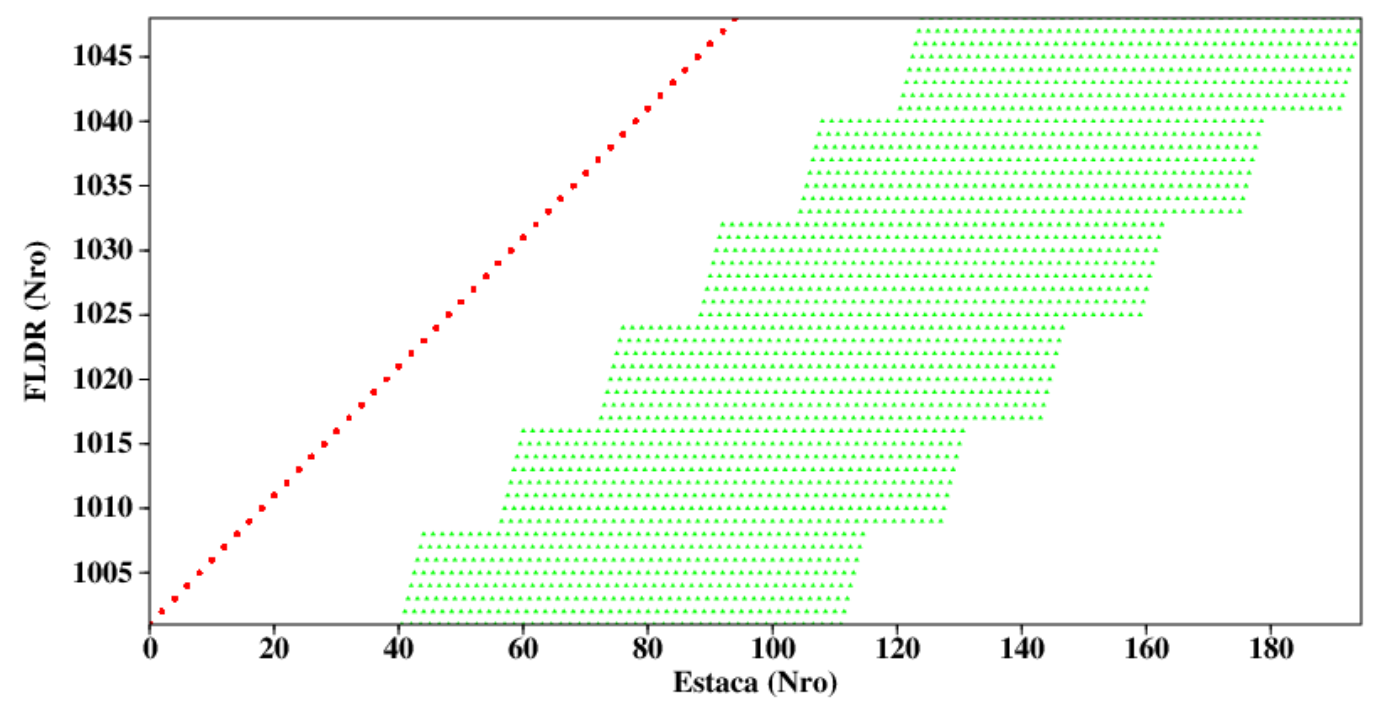

Figura 9.1.3: Geometria de aquisição. Posição das fontes e pontos assintóticos de conversão comuns (ACCP) com $V p / V s=3$, as quais estão referidas aos números de estacas a partir de zero para o primeiro tiro e aos números de arquivo de aquisição (FLDR) que iniciam em 1001. Os pontos vermelhos indicam as posições de fontes e os pontos verdes indicam as posições CMP calculadas.

a)

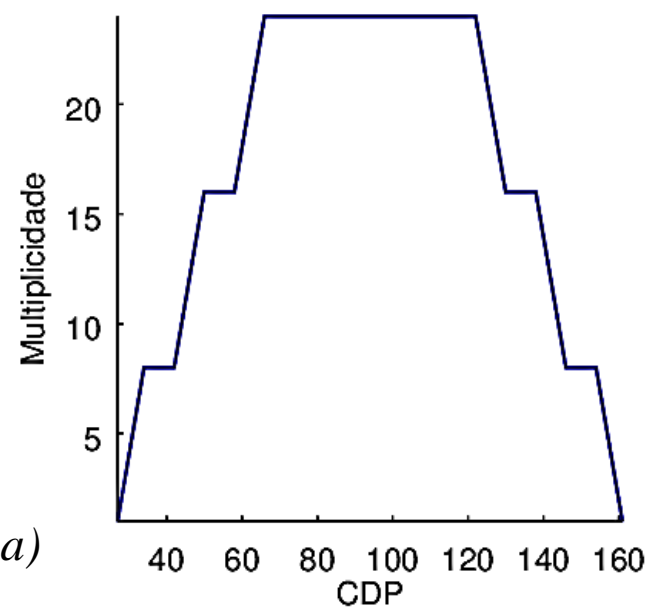

b)

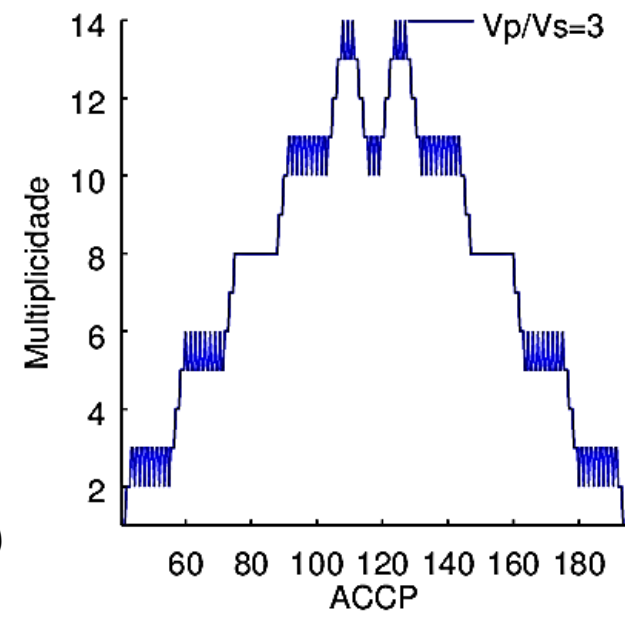

Figura 9.1.4: Multiciplidade de traços a) para CDP na componente vertical; b) para ACCP nas componentes horizontais $(\mathrm{Vp} / \mathrm{Vs}=3)$.

\subsection{Edição dos traços}

Foi realizada a edição dos traços ruidosos. Não foi preciso realizar a conversão da polaridade devido à geometria de aquisição empregada.

\subsection{Análise de polarização}

Quando a onda se propaga através do meio o movimento de deslocamento das partículas é complexo, formando hodógrofos. Numa faixa do tempo as curvas hodográficas podem ser ajustadas a uma elipsoide no sentido de mínimos quadrados por meio de análise de 
covariância. No SU essa análise pode ser realizada usando o comando "supolar", obtendo-se a direção de polarização e a forma de polarização (linearidade ou planaridade) (Maercklin, 2001). A análise do parâmetro de planaridade se mostra na Figura 9.3.1, onde a cor preta indica a presença de sinal planar. Usando os parâmetros determinados se aplica o filtro de polaridade "supofilt". A finalidade desse filtro é extrair parte das ondas superficiais. A aplicação deste filtro, no caso dos dados da USP, extraiu só uma pequena porcentagem desse ruído, sem prejudicar o sinal de interesse.

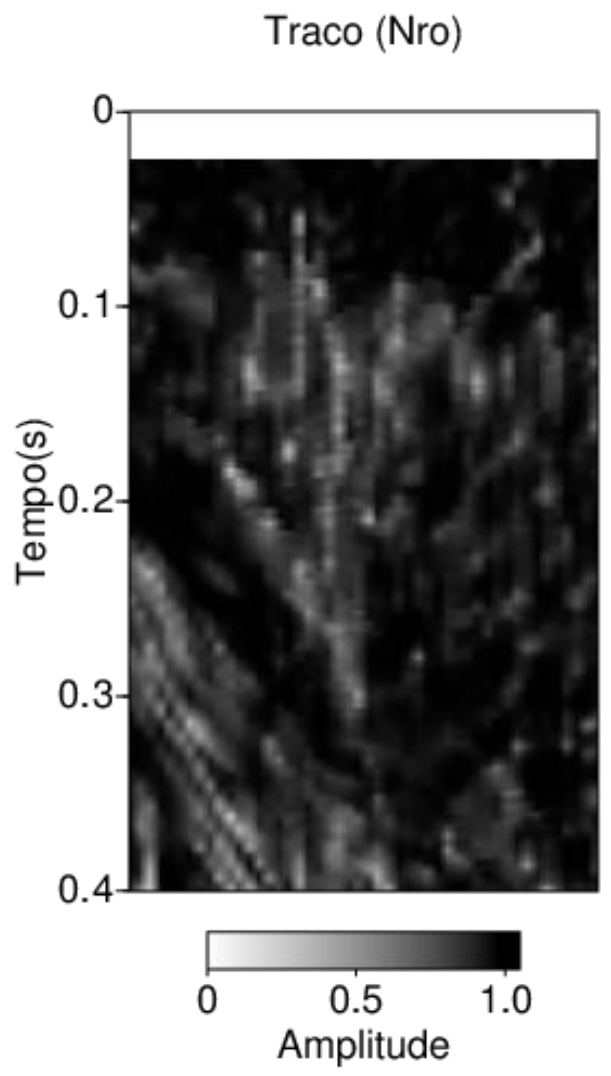

Figura 9.3.1: FLDR 2017. Análise de polarização: Planaridade. O valor "1" indica a presença de sinal planar.

\subsection{Análise espectral}

As Figuras a seguir mostram os sismogramas das três componentes e respectivos espectros de amplitude do conjunto de tiro FLDR 1027. As Figuras 9.4.1 d,e,f mostram os espectros de amplitude na faixa de frequências 0-160 Hz, e as Figuras 9.4.2 a,b mostram os espectros das componentes vertical e radial em uma faixa reduzida $0-80 \mathrm{~Hz}$ e $0-120 \mathrm{~Hz}$, respectivamente. Contrário ao caso dos dados de Colônia, o espectro de amplitudes dos dados da USP não diferencia as energias associadas às ondas PP das energias das ondas de 
superfície. Nas componentes horizontais se observa um pequeno pico de energia correspondente às ondas PS, aproximadamente na frequência de $115 \mathrm{~Hz}$ (Figuras 9.4.1 e,f; 9.4.2 b).
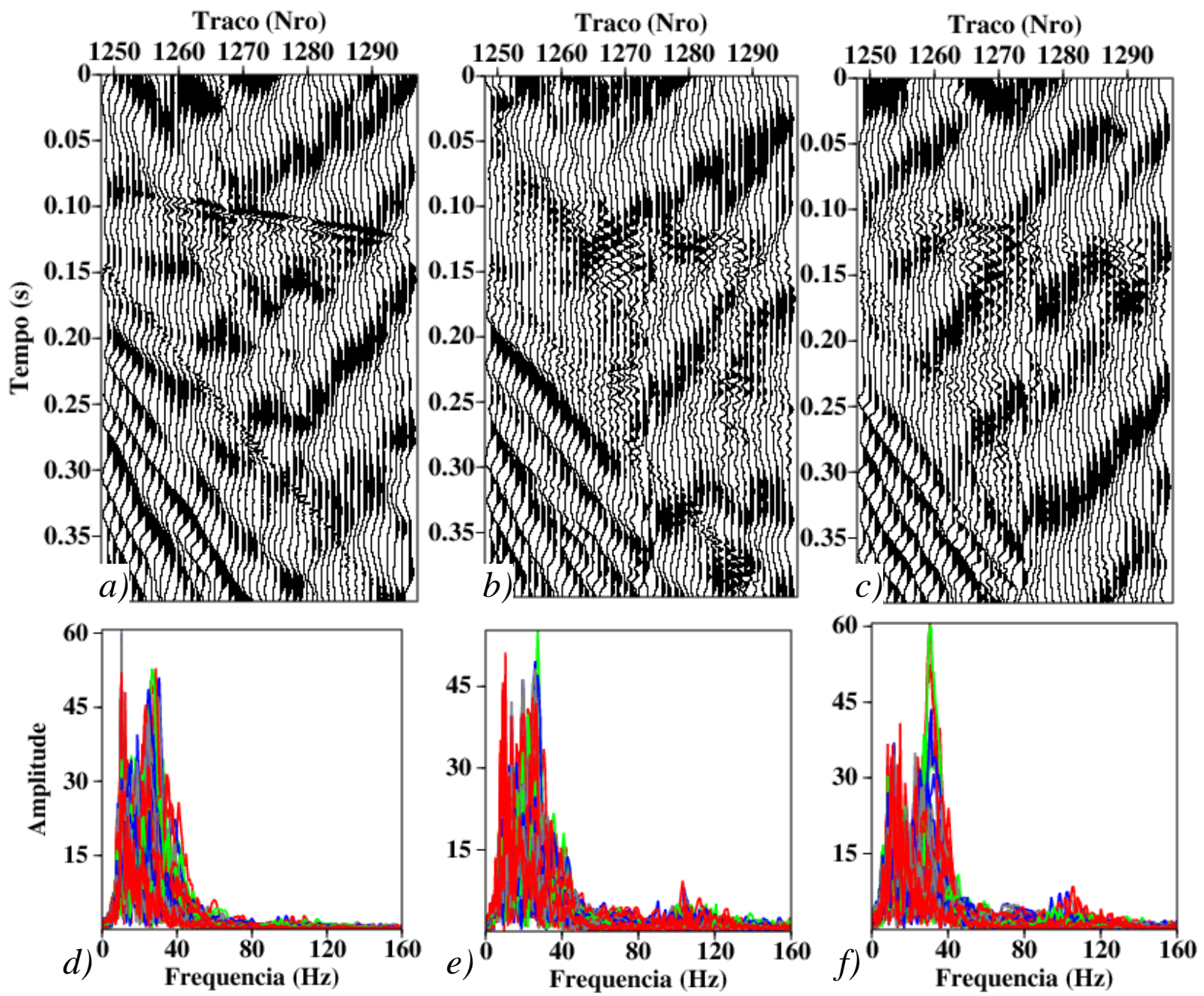

Figura 9.4.1: Conjuntos de tiro das componentes a) vertical; b) horizontal radial; c) horizontal transversal e seus respectivos espectros de frequências d), e) ef) (Sismograma FLDR 1027).
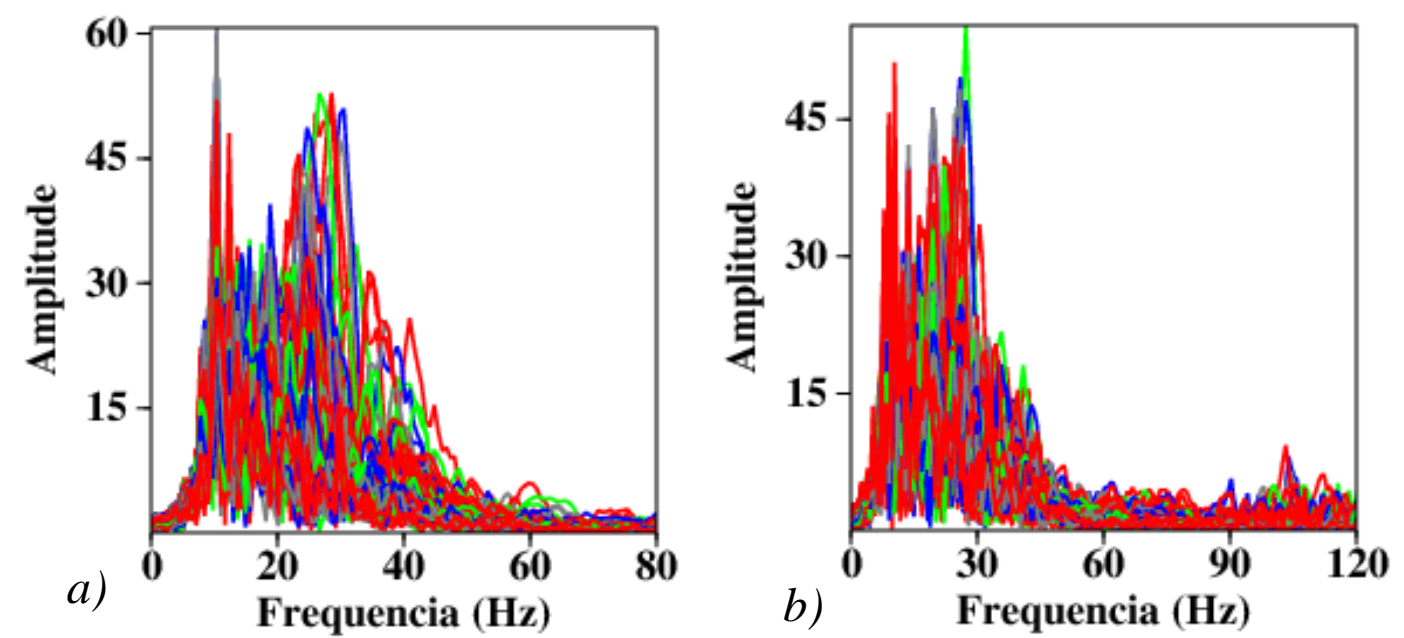

Figura 9.4.2: Espectros de amplitude da componente vertical a) e componente horizontal radial b) em uma faixa de frequências reduzida (sismograma FLDR 1027). 


\subsection{Aplicação de filtro passa-banda}

Se analisou a janela ótima para a aplicação de filtro passa-banda (PB) na componente vertical, assim como os efeitos da aplicação de filtro ao dado com ganho ou sem ganho. Como não foram detectadas diferenças relevantes, foi aplicado o filtro ao dado sem ganho. A janela para o filtro PB escolhida para as três componentes foi de $20 \mathrm{~Hz}, 25 \mathrm{~Hz}, 150 \mathrm{~Hz}$ e $165 \mathrm{~Hz}$. A equalização do dado para a visualização foi realizada mediante uso do comando "sugain" do SU, através da rotina AGC (Automatic Gain Control- Controle de Ganho Automático) com a janela de 0.5 segundos. Para análise comparativa dos resultados de aplicação de filtro na componente vertical dos conjuntos de tiros são apresentadas as seções empilhadas dos dados não filtrados (Figura 9.5.1), dados sem ganho e filtrados (Figura 9.5.2) e a diferença das seções empilhadas do dado original com dado filtrado (Figuras 9.5.3). A diferença entre o dado original e o dado filtrado nos mostra o ruído, assim como os sinais que foram subtraídos no processo.

Os resultados da aplicação desse processo na componente horizontal radial são apresentados nas Figuras 9.5.5 e 9.5.6, em contraste com a seção empilhada do dado sem filtrar (Figura 9.5.4). Nas seções da componente radial (Figuras 9.5.5) se observa a energia das ondas convertidas entre os 0.15 e 0.2 segundos.

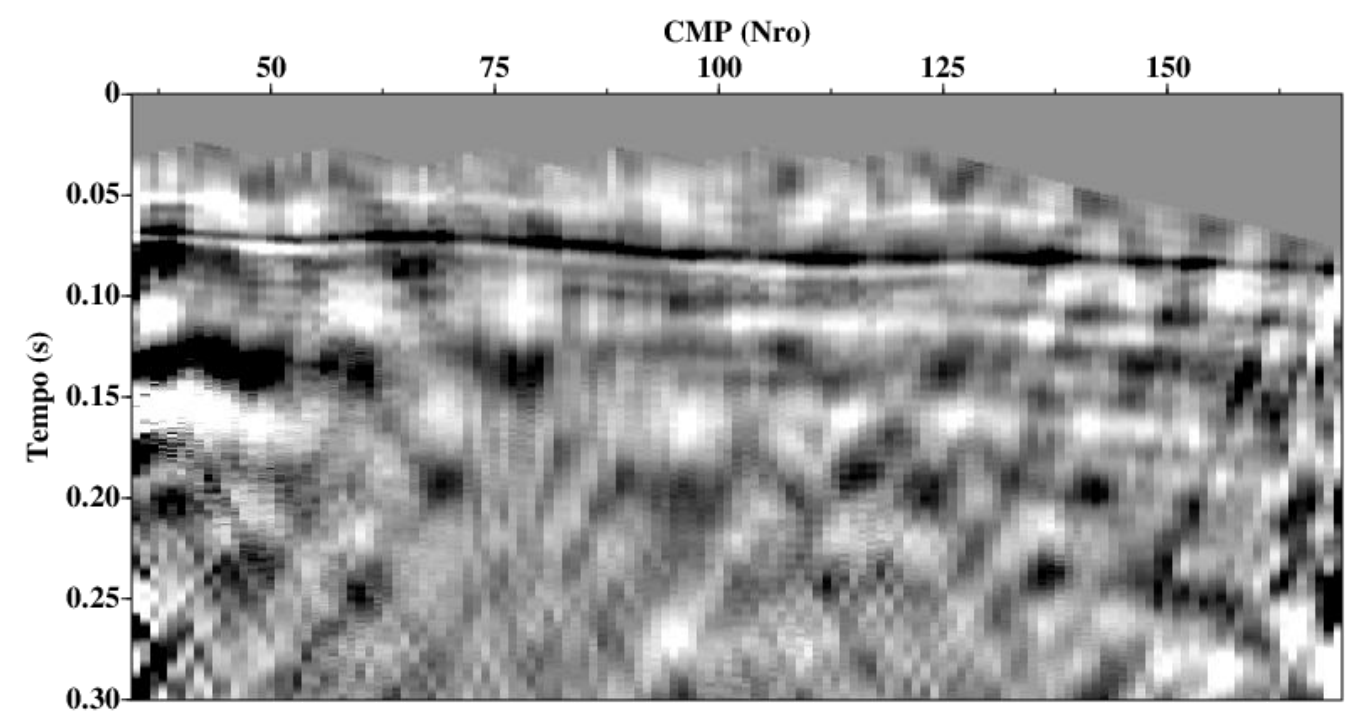

Figura 9.5.1: Seção de dados empilhados sem filtrar. Foi aplicado ganho para a visualização (AGC com janela de $0,5 \mathrm{~s}$ ) 


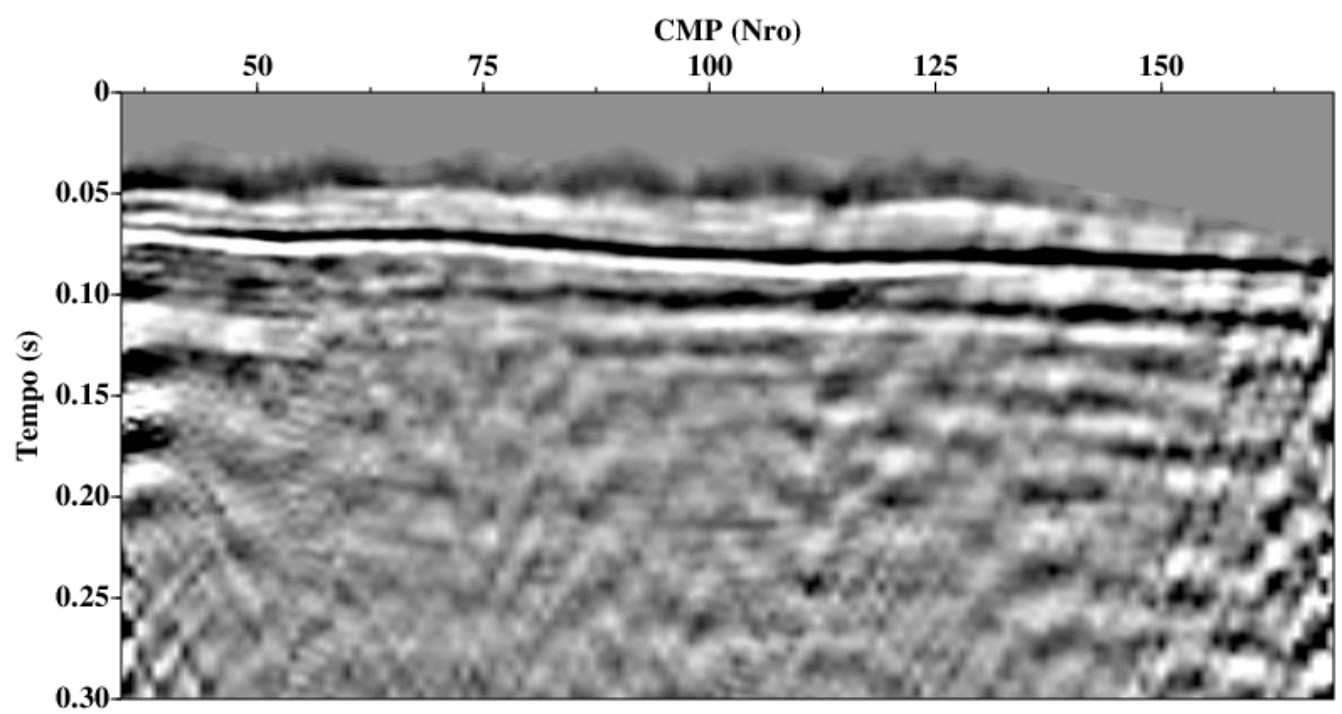

Figura 9.5.2: Seção de dados empilhados com PB aplicado ao dado sem ganho. Foi aplicado ganho para a visualização (AGC com janela de $0,5 \mathrm{~s}$ )

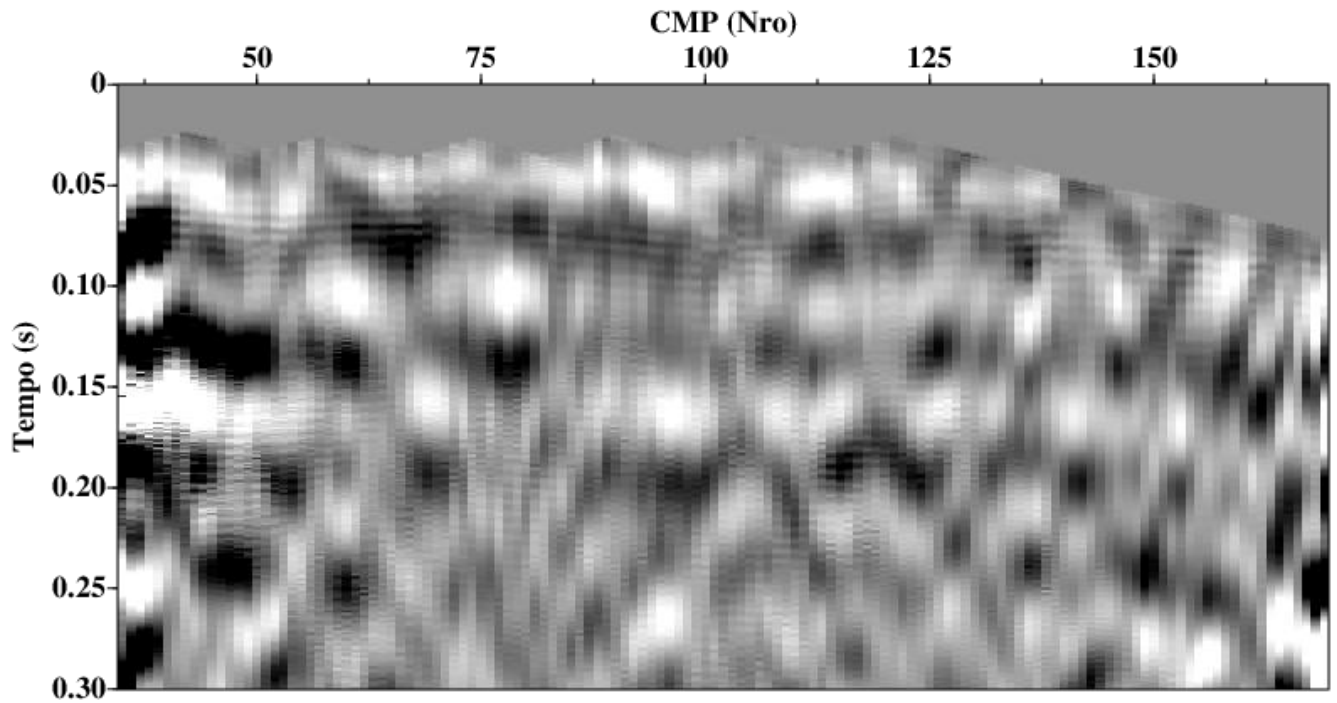

Figura 9.5.3: Diferença das seções empilhadas do dado original com dado filtrado. Foi aplicado ganho para a visualização (AGC com janela de $0,5 \mathrm{~s}$ )

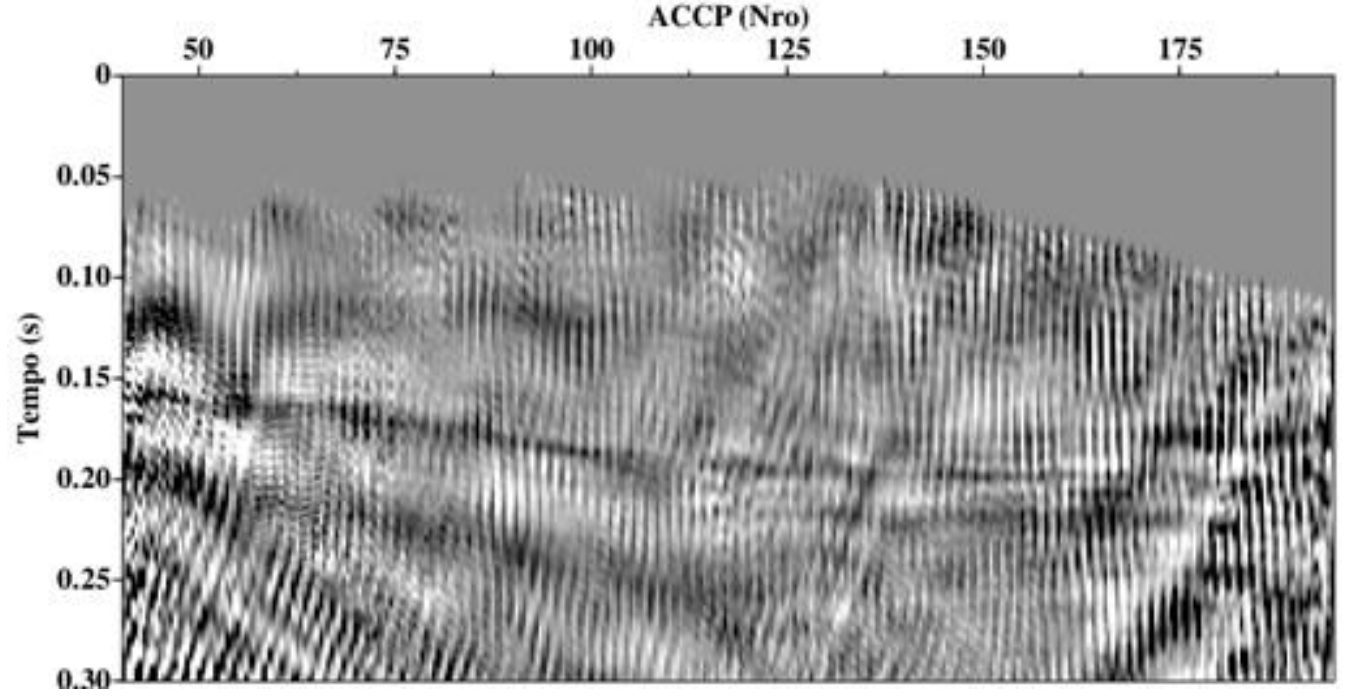

Figura 9.5.4: Componente horizontal radial. Seção de dados empilhados sem filtrar. Foi aplicado o ganho para a visualização (AGC com janela de $0,5 \mathrm{~s}$ ) 


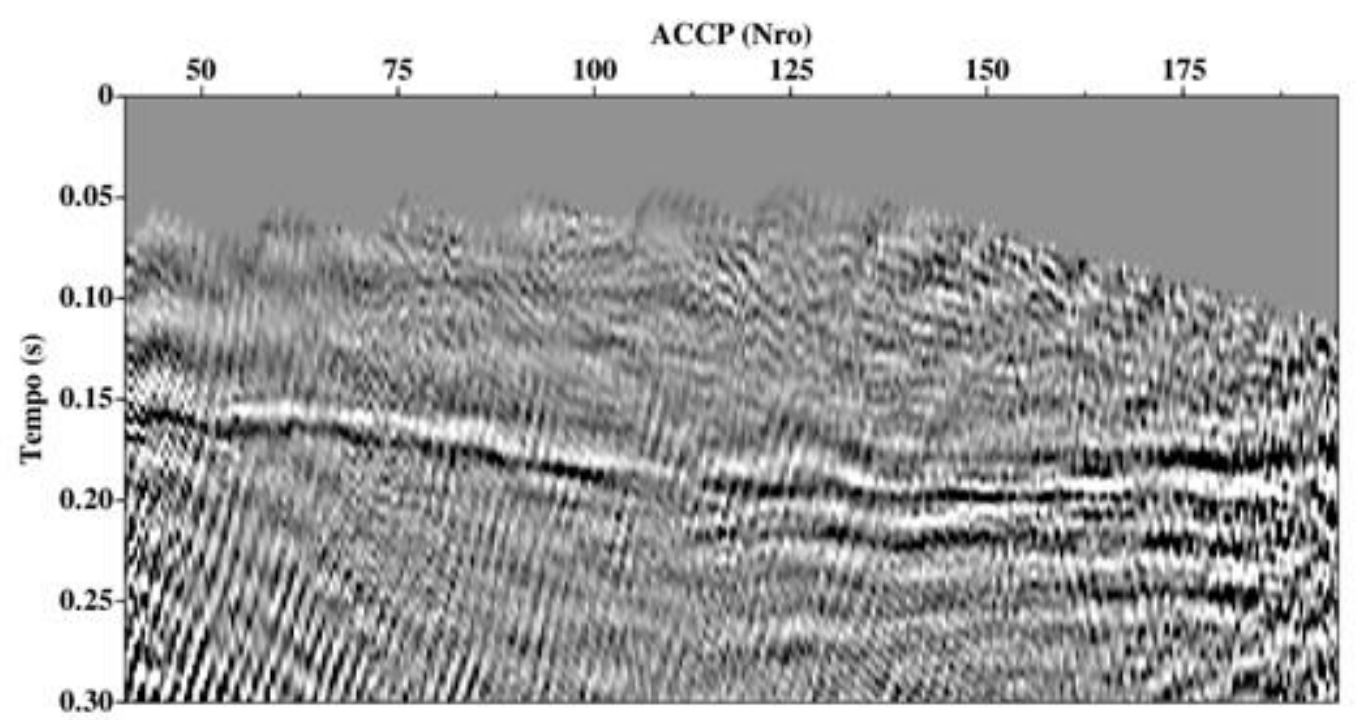

Figura 9.5.5: Componente horizontal radial. Seção empilhada sobre o ACCP com PB aplicado ao dado sem ganho. Foi aplicado o ganho para a visualização (AGC com janela de 0,5 s).

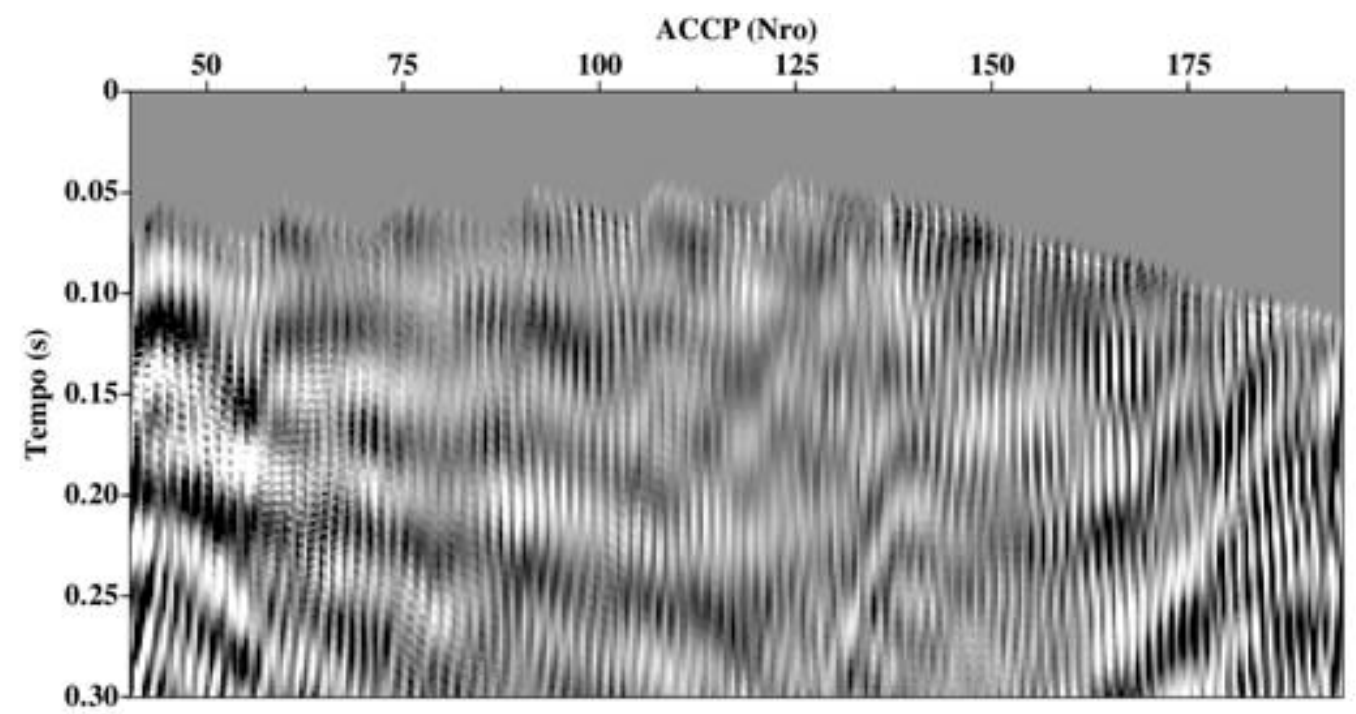

Figura 9.5.6: Componente horizontal radial. Diferença das seções empilhadas do dado original com dado filtrado. Foi aplicado ganho para a visualização (AGC com janela de 0,5 $\mathrm{s}$ )

Se conclui, neste caso, que a aplicação de filtro $\mathrm{PB}(\mathrm{f}=20 \mathrm{~Hz}, 25 \mathrm{~Hz}, 150 \mathrm{~Hz}, 165 \mathrm{~Hz})$ ao dado sem ganho ajuda na extração de ruído sem prejudicar o dado no processo.

\subsection{Aplicação de filtro F-K}

Na Figura 9.6.1 se mostram os espectros f-k das três componentes do sinal, vertical, radial e transversal de um dos conjuntos de tiro do levantamento (FLDR 1027). 

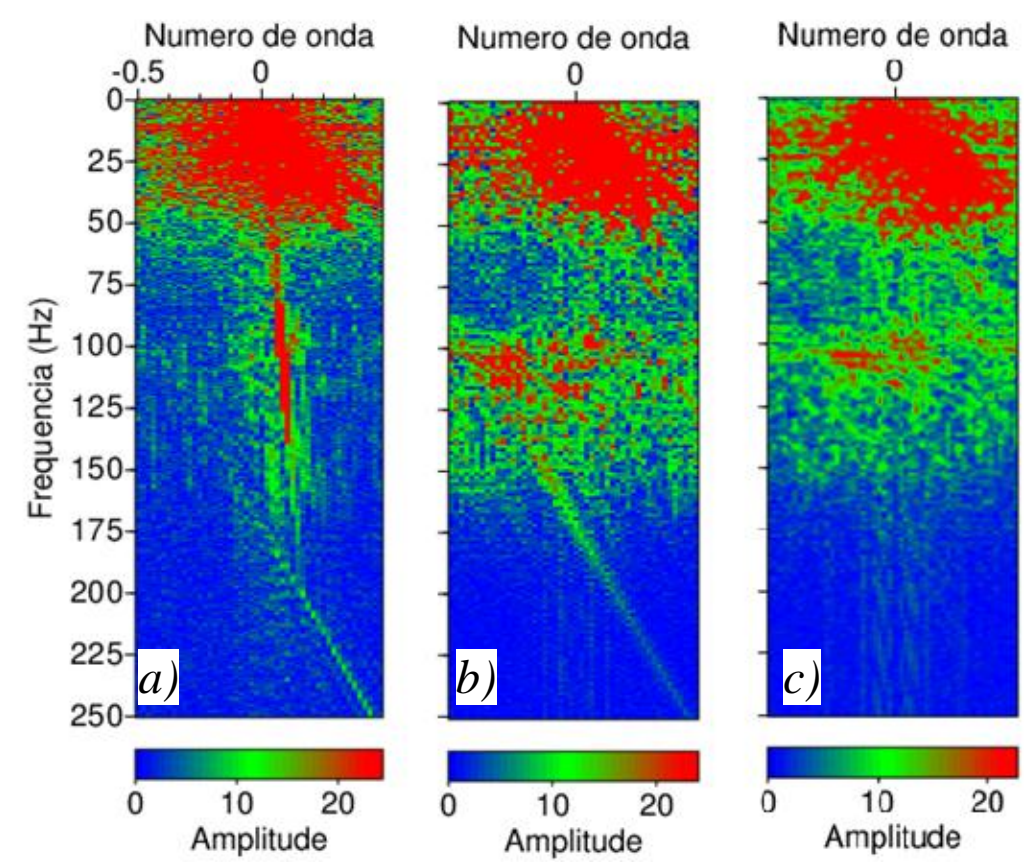

Figura 9.6.1: Espectros do sinal no domínio f-k das componentes a) vertical; b) horizontal radial e c) horizontal transversal (sismograma FLDR 1027)

Neste caso também se experimentou diferentes parâmetros do filtro f-k (inclinações das retas no domínio f-k) para os sismogramas da componente vertical, assim como a aplicação do filtro ao dado com ganho e sem ganho (AGC). Os parâmetros de filtro ótimos encontrados para a componente vertical foram as inclinações $(\mathrm{k} / \mathrm{f})=-0.001,-0.00,0.001,0.002 \mathrm{e}$ bias $=0.0035$. O filtro $\mathrm{f}-\mathrm{k}$ foi aplicado ao dado previamente filtrado com o filtro PB (com os parâmetros definidos anteriormente). Nas figuras a seguir se observam os resultados na seção empilhada da aplicação do filtro f-k à componente vertical (Figura 9.6.2 e Figura 9.6.3)

Nas componentes horizontais foi aplicado filtro f-k com os parâmetros inclinações=$0.002,-0.001,0.004,0.005$ e bias=0.0035. O ganho usado foi o AGC com janela temporal de 0,5 s. Nas Figuras 9.6.4 e 9.6.5 se mostram as seções empilhadas dos conjuntos de receptor e dos conjuntos $\mathrm{ACCP}(\mathrm{Vp} / \mathrm{Vs}=3)$ da componente radial filtrada, respectivamente. Devido à aproximação dos pontos de conversão calculados, a qualidade da imagem é afetada (Figura 9.6.4). Neste caso a aplicação de Mute nos últimos traços de conjunto de ACCP diminui a dispersão dos pontos agrupados no conjunto e favorece à melhora da qualidade da seção empilhada (Figura 9.6.6) 


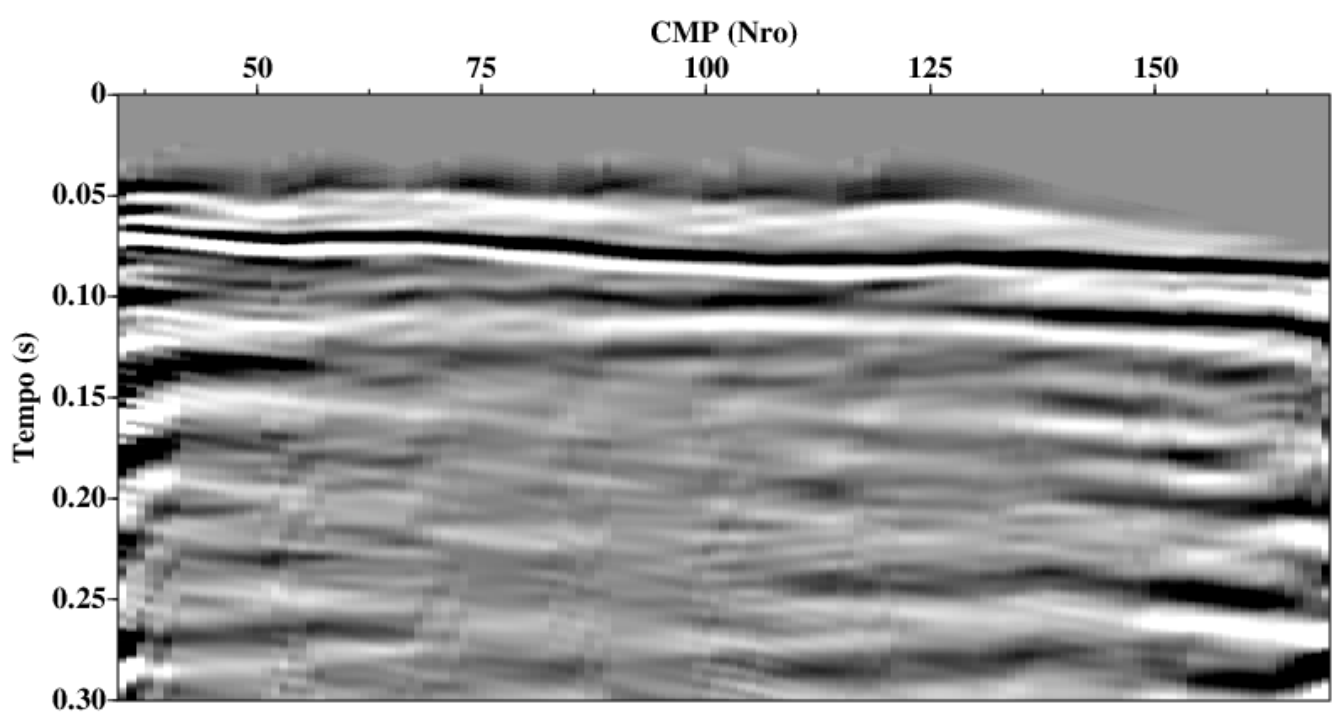

Figura 9.6.2: Componente Vertical. Seção empilhada de dados com filtro FK aplicado ao dado sem ganho. Parâmetros do filtro aplicado: $(\mathrm{k} / f)=-0.001,-0.00,0.001,0.002$ e o bias $=0.0035$. Foi aplicado ganho para a visualização (AGC com janela de 0,5 s).

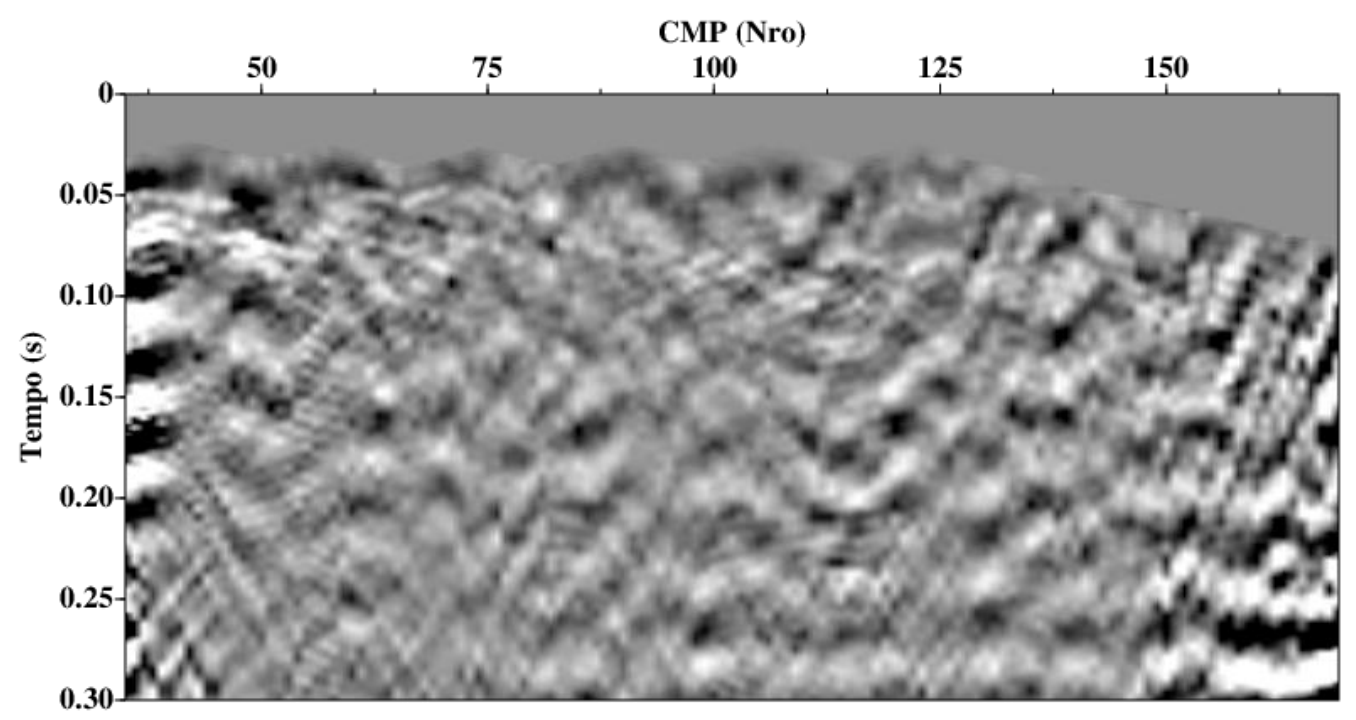

Figura 9.6.3: Componente vertical. Imagem da diferença das seções empilhadas dos dados sem filtro FK e com filtro FK aplicado ao dado sem ganho. Parâmetros do filtro aplicado: $(\mathrm{k} / f)=-0.001$,0.00,0.001,0.002 e bias=0.0035. Foi aplicado ganho para a visualização (AGC com janela de 0,5 s). 


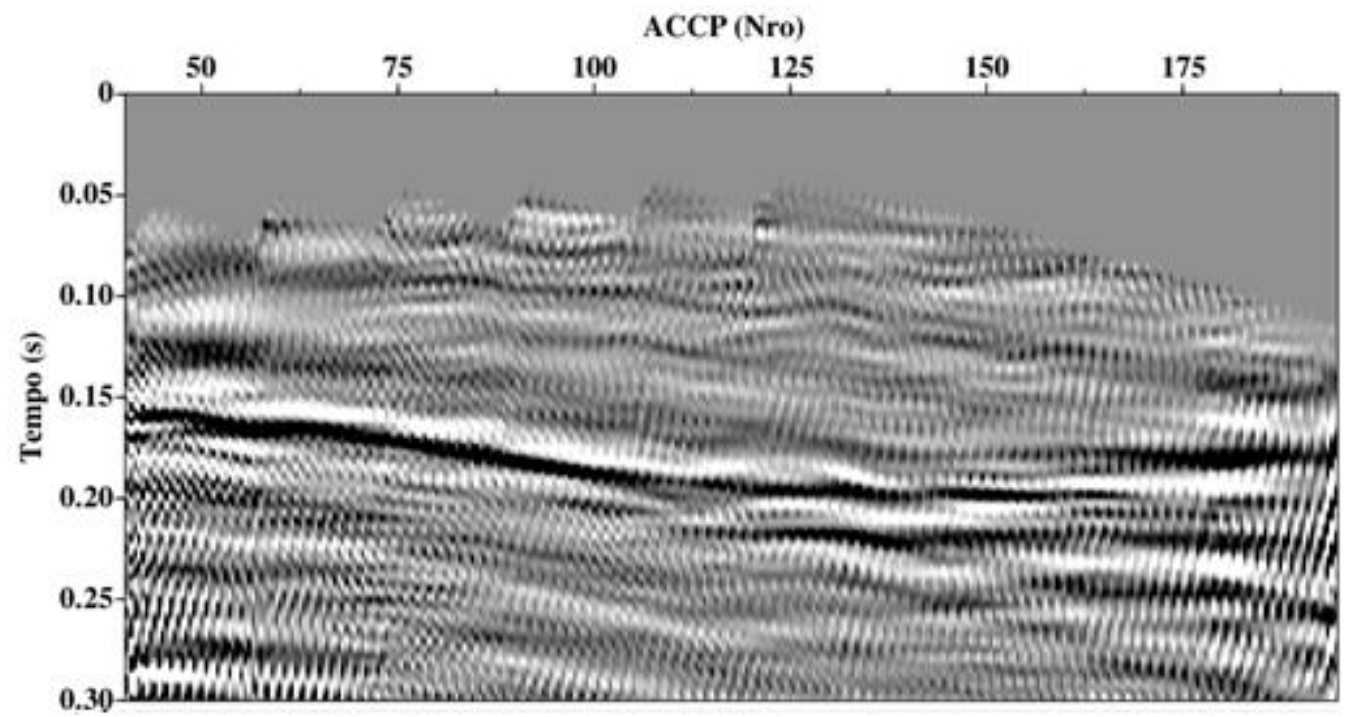

Figura 9.6.4: Componente horizontal radial. Seção empilhada em ACCP com filtro FK aplicado ao dado sem ganho. Parâmetros do filtro aplicado, inclinações=-0.002,-0.001,0.004,0.005 e bias $=0.0035$. Foi aplicado ganho para a visualização (AGC com janela de 0,5 s).

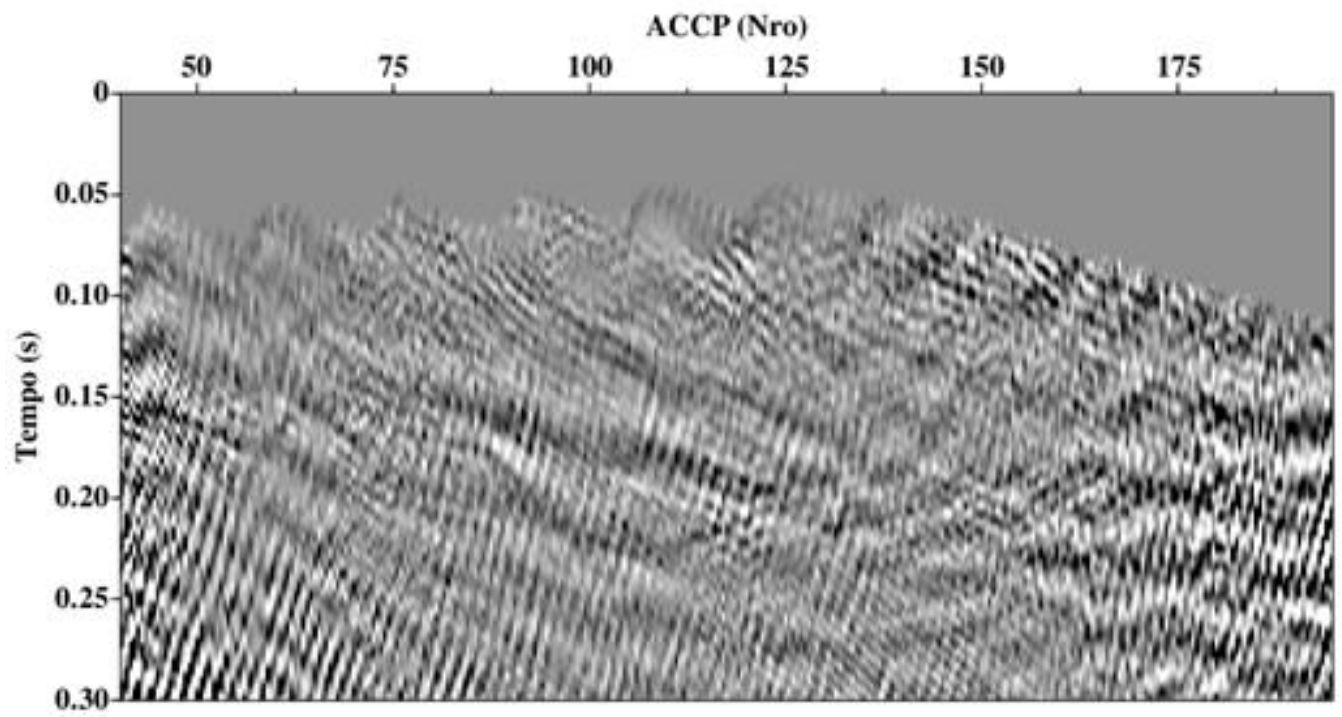

Figura 9.6.5: Componente horizontal radial. Imagem da diferença das seções empilhadas dos dados sem filtro FK e com filtro FK aplicado ao dado sem ganho. Parâmetros do filtro aplicado, inclinações $=-0.002,-0.001,0.004,0.005$ e bias $=0.0035$. Foi aplicado o ganho para a visualização (AGC com janela de $0,5 \mathrm{~s}$ ). 


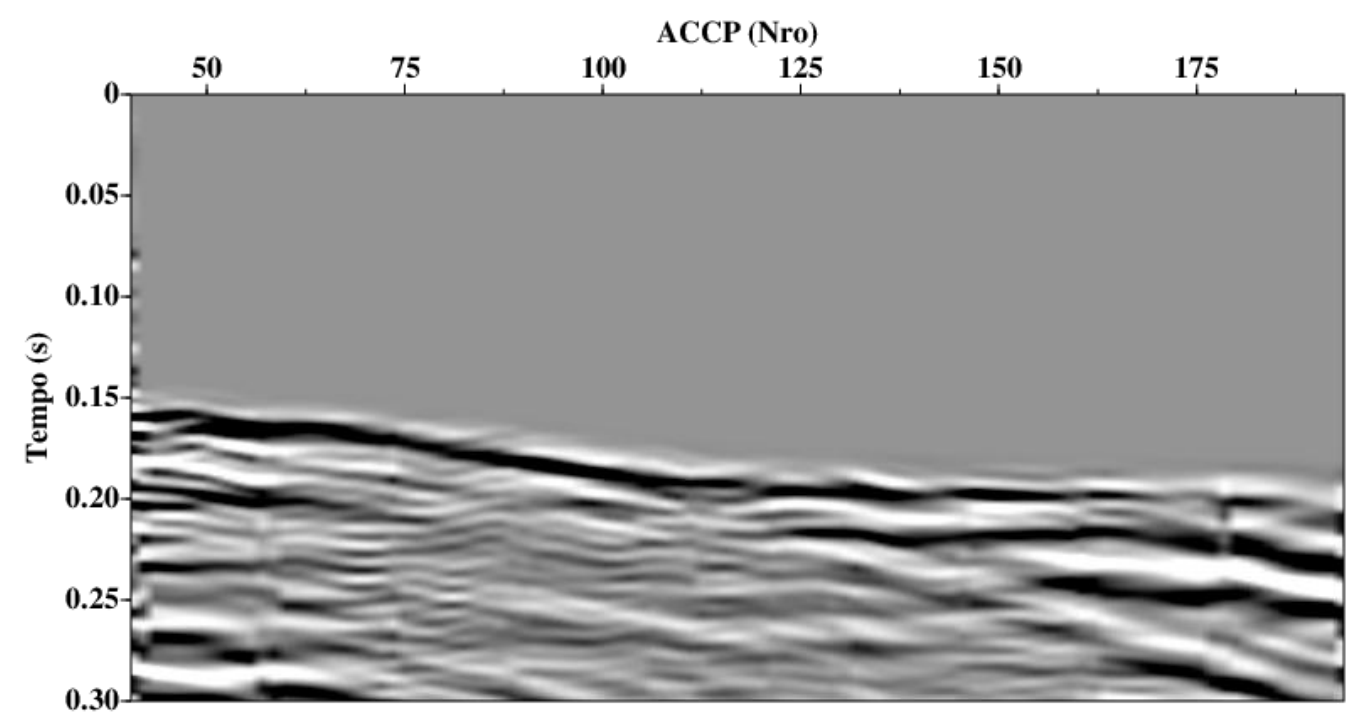

Figura 9.6.6: Componente horizontal radial. Seção empilhada em ACCP com filtro FK e Mute aplicado.

\subsection{Deconvolução}

Partindo da autocorrelação dos traços da componente vertical (Figura 9.7.1), foram determinados os parâmetros da deconvolução: minlag=0.0005 s e maxlag=0.07 s. Seguindo os critérios propostos pelo programa supef do SU, minlag está associado ao tamanho da wavelet que se deseja preservar (aproximadamente a largura da wavelet da autocorrelação), e maxlag ao número de parâmetros do filtro de predição que se deseja. O resultado da aplicação da deconvolução é mostrado na Figura 9.7.2.
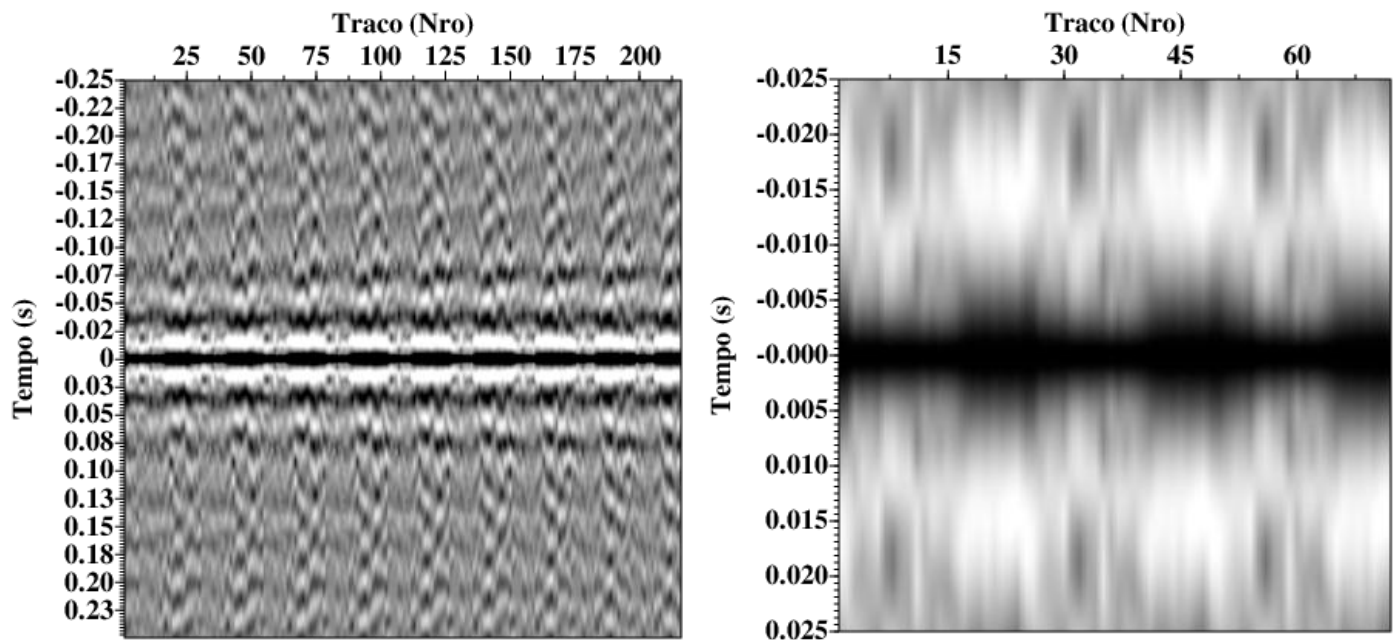

Figura 9.7.1: Imagens do resultado da autocorrelação dos traços (autocorrelograma) da componente vertical do sismograma 


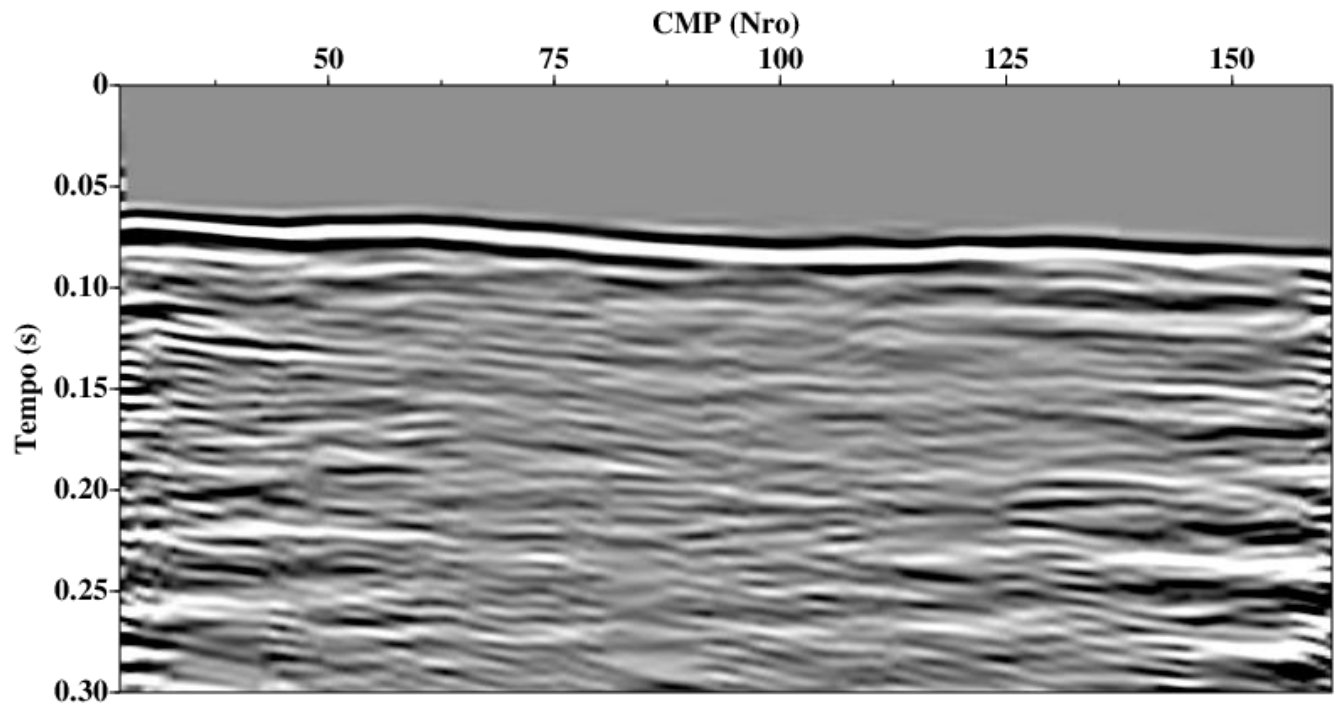

Figura 9.7.2: Seção empilhada de dado deconvolvido. Componente vertical-Coordenadas CMP ( $x=0$ posição inicial da fonte sísmica)

Um set de parâmetros diferentes foi determinado a partir de autocorrelação dos traços das componentes horizontais (Figura 9.7.3), onde minlag=0.01 e maxlag=0.05 foram os parâmetros escolhidos. O resultado de aplicação de deconvolução usando esses parâmetros é mostrado na Figura 9.7.4.
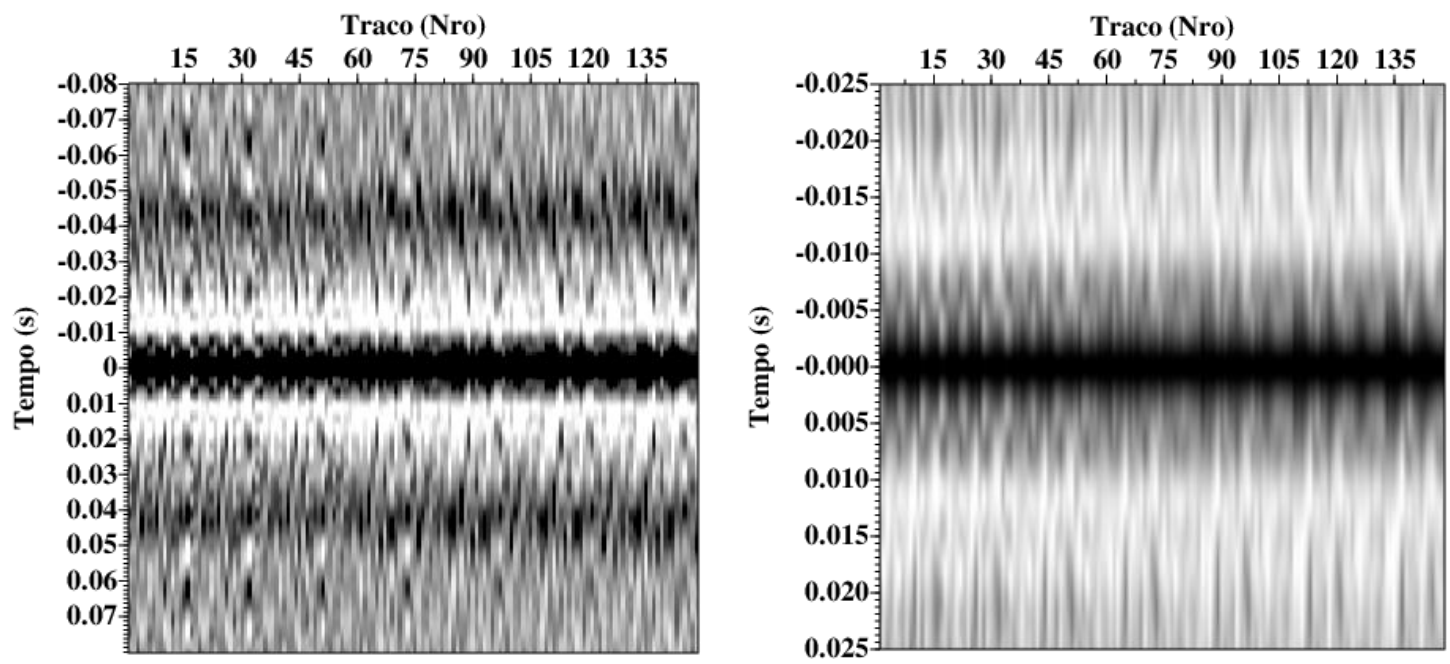

Figura 9.7.3: Autocorrelaçao de traços da componente horizontal radial. 


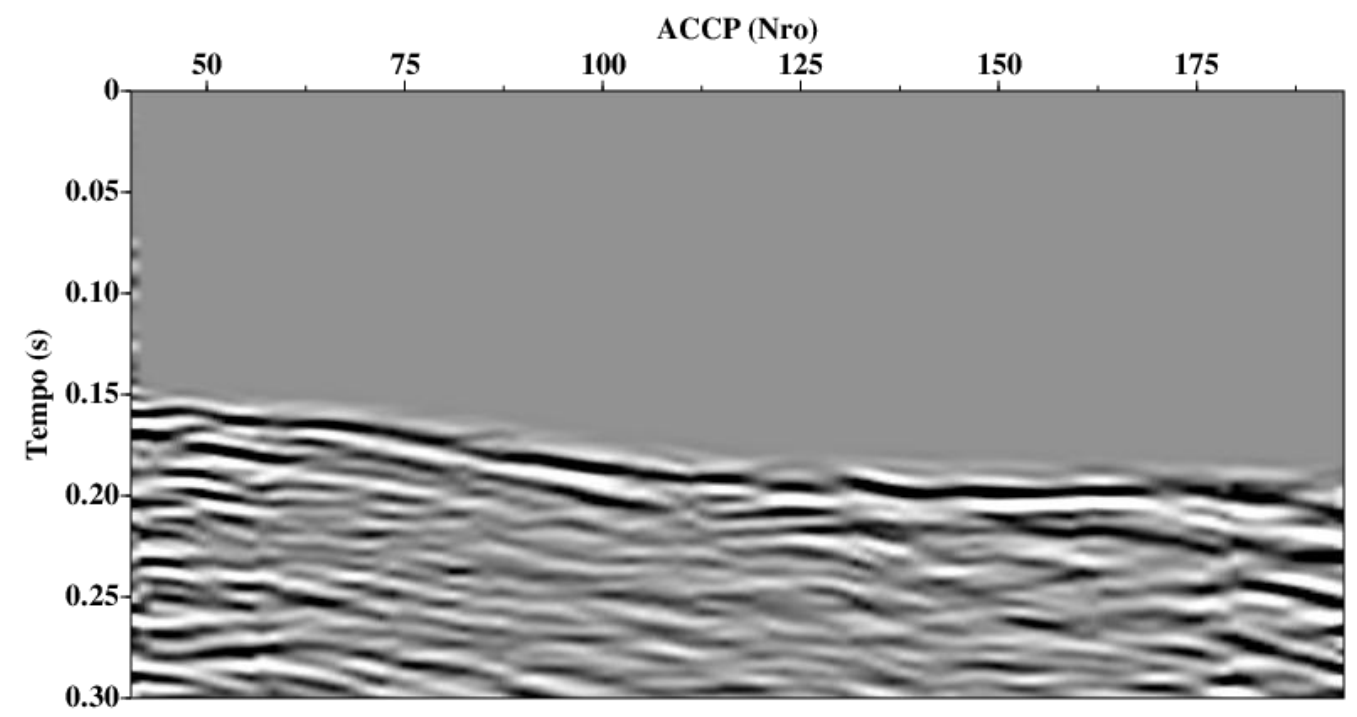

Figura 9.7.4: Seção empilhada de dado deconvolvido. Componente horizontal radial-Coordenadas ACCP ( $x=0$ posição inicial da fonte sísmica)

\subsection{Análise de velocidade}

A análise de velocidade foi realizada usando diferentes métodos. Os dados foram analisados através da função semblance, painel CVS (constant velocity stacking) e painel NMO. O modelo de velocidades foi melhorado de forma iterativa. Na Figura 9.8.1 se observa o gráfico da função semblance antes e depois de aplicada a deconvoluçao aos conjuntos CMP.
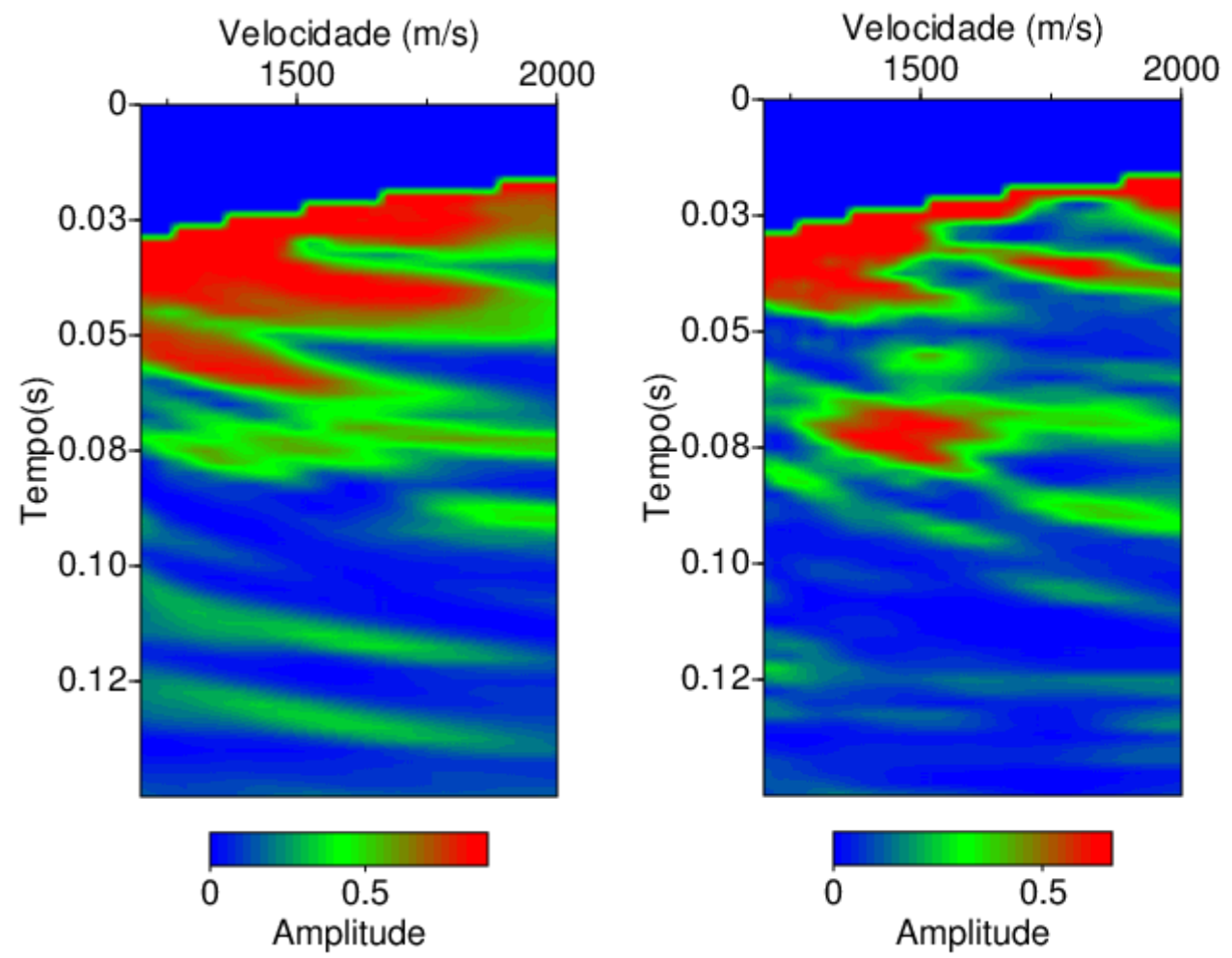

Figura 9.8.1: Gráfico da função semblance do conjunto CMP 67 antes da deconvolução (esquerda) $e$ após a aplicação da deconvolução (direita). 


\section{Discussão}

Após a obtenção e interpretação das seções empilhadas foram feitas modelagens das ondas acústicas para as duas áreas estudadas. No caso de Colônia, partindo da hipótese da ocorrência de três camadas horizontais e paralelas que terminam em estrutura onlap contra o embasamento (inclinado), construiu-se um modelo geológico com camadas relativas ao sedimentos de velocidades médias V1 $=1270 \mathrm{~m} / \mathrm{s}, \mathrm{V} 2=1550 \mathrm{~m} / \mathrm{s}$ e V3 $=1800 \mathrm{~m} / \mathrm{s}$, e embasamento com velocidade $\mathrm{V} 4=4500 \mathrm{~m} / \mathrm{s}$. Neste modelo, as profundidades estimadas para os topos das camadas sedimentares foram de $40 \mathrm{~m}$ e $97 \mathrm{~m}$ e para o embasamento variaram de $90 \mathrm{~m}$ a $160 \mathrm{~m}$ (Figura 10.2a). Se observa uma boa concordância da seção sintética com a seção das ondas PP gerada a partir dos dados adquiridos. Atribui-se as demais aparentes reflexões observadas no dado experimental à reverberações que não foram eliminadas no processo (Figura 10.1 e Figura $10.2 b)$.

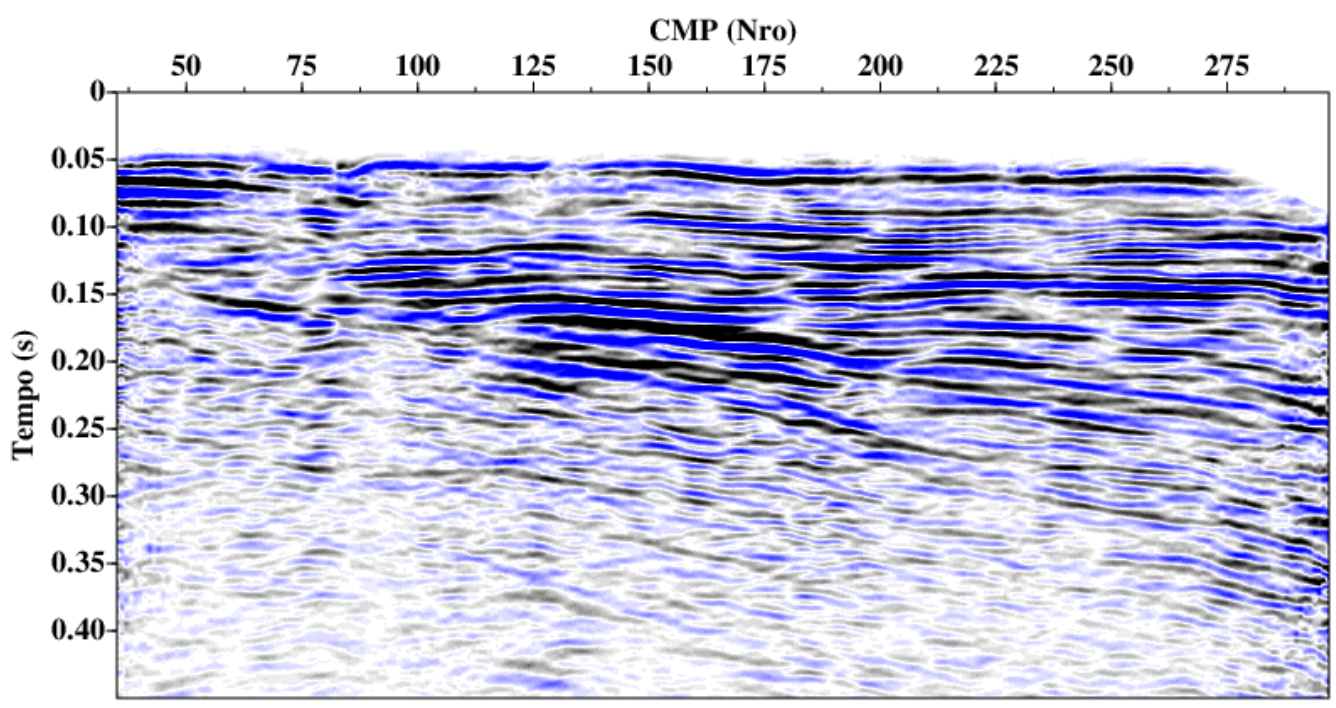

Figura 10.1: Área de Colônia. Seção empilhada da componente vertical.

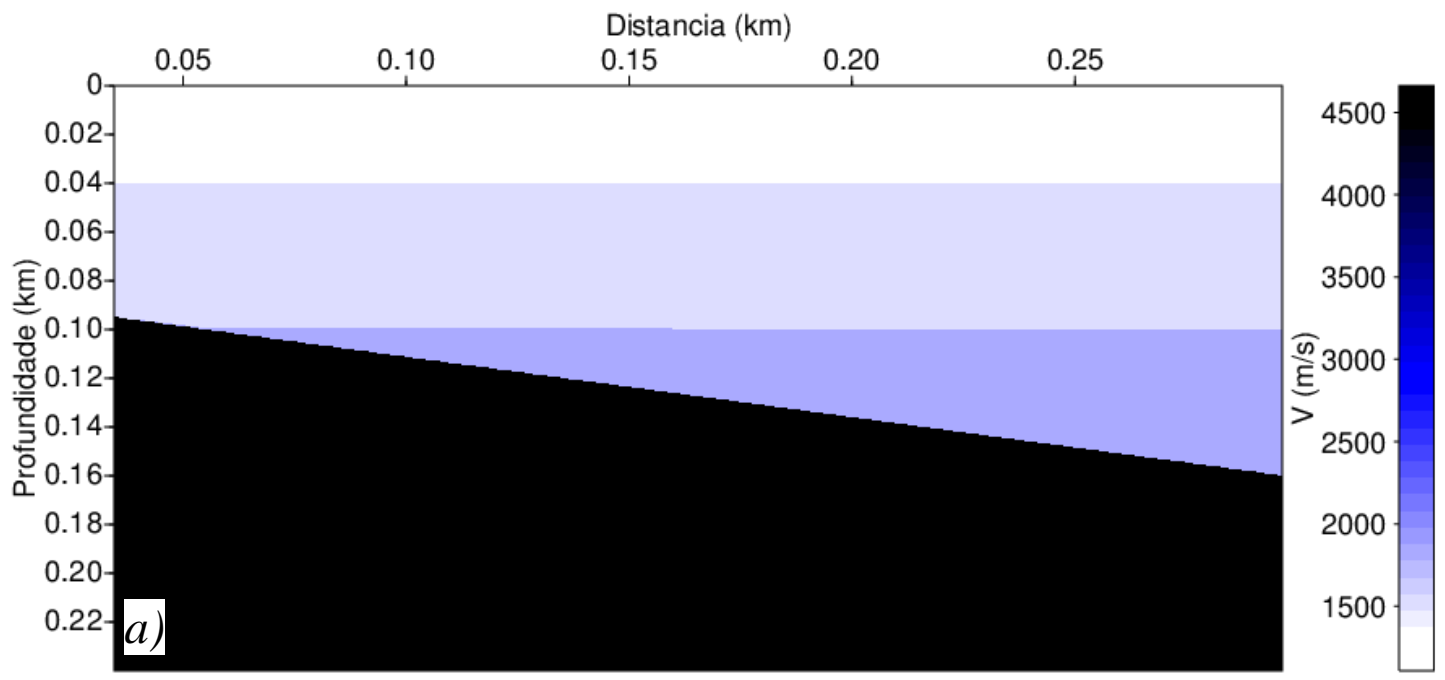



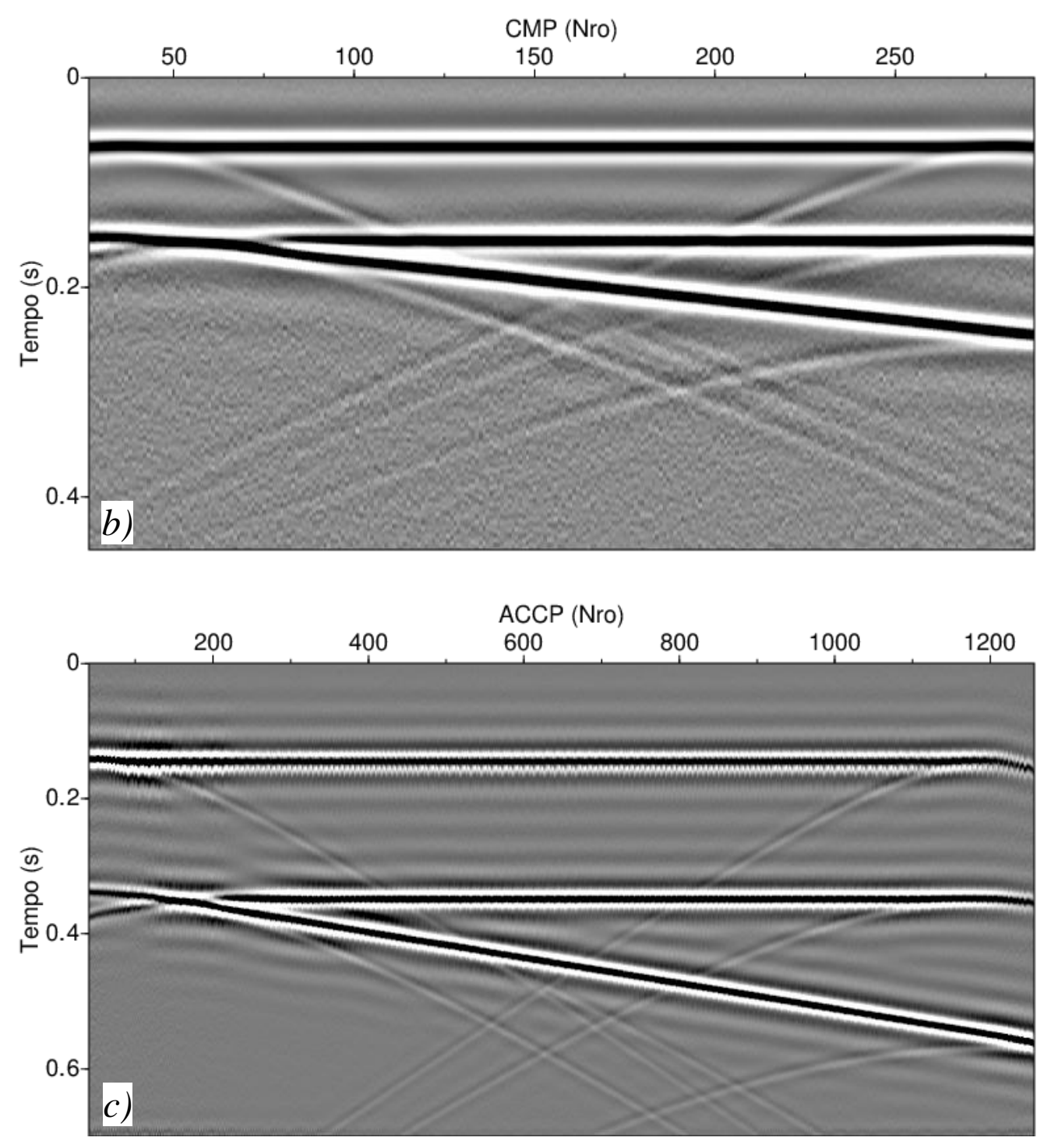

Figura 10.2: Área de Colônia: modelo geológico. a) modelo estrutural; b) seção modelada das ondas $P P$ com parâmetros: $V 1=1270 \mathrm{~m} / \mathrm{s}, V 2=1550 \mathrm{~m} / \mathrm{s}$ e V3=1800m/s V4=4500m $/ \mathrm{s}, h 1=40 \mathrm{~m}, \mathrm{~h} 2=97 \mathrm{me}$ profundidade do embasamento variando de $90 \mathrm{~m}$ a $160 \mathrm{~m}$; c) seção modelada das ondas PS com $V p / V s=3.5$.

O modelo das ondas PS mostra os tempos estimados para a seção empilhada para o caso de $\mathrm{Vp} / \mathrm{Vs}=3.5$ (Figura 10.2c). Nas seções mostradas nos capítulos anteriores as ondas convertidas não foram observadas nesses tempos. A ausência da fase PS pode ser devida a duas causas: a amplitude pequena da reflexão ou a não propagação das ondas S. As Figuras 10.3 e 10.4 apresentam a refletividade das ondas PP e PS simulando a interface com o embasamento, calculada considerando o modelo de velocidades descrito anteriormente e meio isotrópico. Para as condições simuladas, as ondas PS sofrem diminuição do valor absoluto de amplitude de conversão entre 20 e 30 graus e entre 50 e 60 graus de ângulo de incidência. Por outro lado, as ondas PP sofrem diminuição do valor absoluto de amplitude de refletividade entre 50 e 60 graus. 
Partindo da premissa que tem-se boa refletividade para as ondas PP, analisamos a faixa de ângulos de incidência entre 20 e 30 graus. Nesse intervalo de ângulos de incidência (20 e 30 graus) e considerando valores possíveis de densidades aparentes das camadas entre $0.75 \mathrm{~g} / \mathrm{cm} 3$ (para os horizontes mais rasos bastante inconsolidados e com alta porcentagem de matéria orgânica) e $1.25 \mathrm{~g} / \mathrm{cm} 3$ para os mais profundos, também bastante inconsolidados), a faixa de baixa refletividade da onda PS é reduzida. Desta forma, considerando esses cálculos e o fato de que os dados foram adquiridos com offset mínimo de 24 metros e máximo de $164 \mathrm{~m}$, ou seja, em uma ampla faixa de ângulos, se conclui que a refletividade não seria a razão de não se observar ondas convertidas na seção empilhada. Assim, a presença de substrato argiloso bastante inconsolidado, rico em matéria orgânica (especialmente na parte rasa), e saturado parece ser a hipótese mais plausível para explicar a não propagação das ondas $\mathrm{S}$.
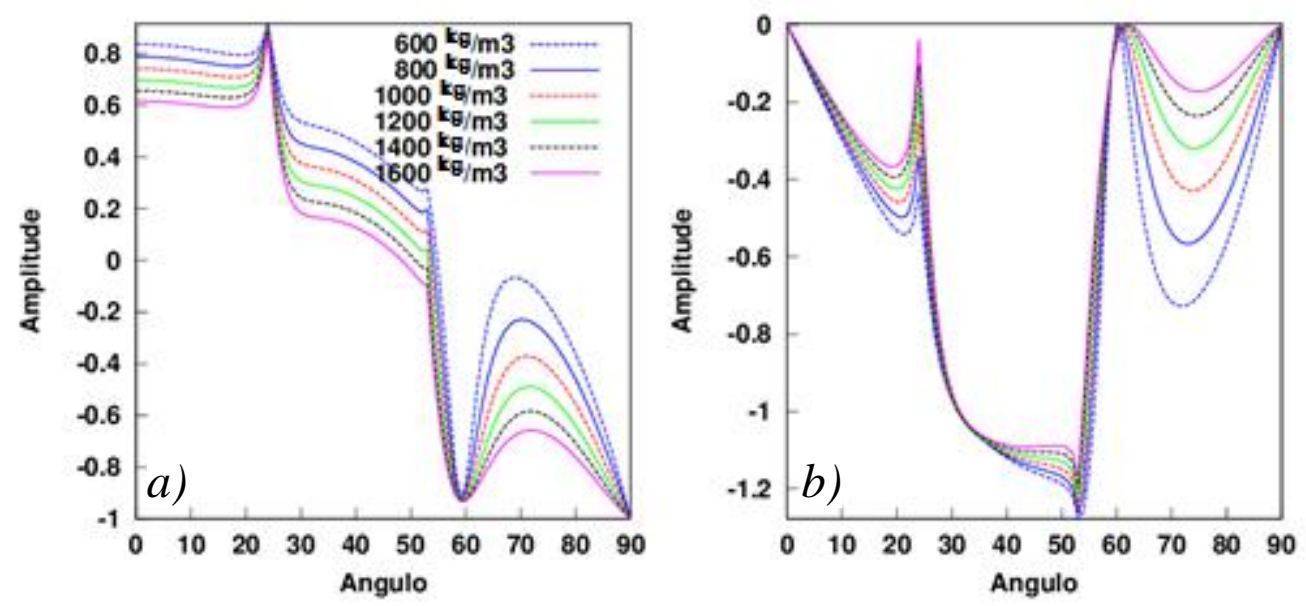

Figura 10.3: Área de Colônia: modelo de refletividade com parâmetros: Vpl=1800m/s, $V p 2=4500 \mathrm{~m} / \mathrm{s}, V s 1=520 \mathrm{~m} / \mathrm{s}, V s 2=2250 \mathrm{~m} / \mathrm{s}$. a) coeficiente de reflexão $R p p$ b) coeficiente de reflexão Rps.
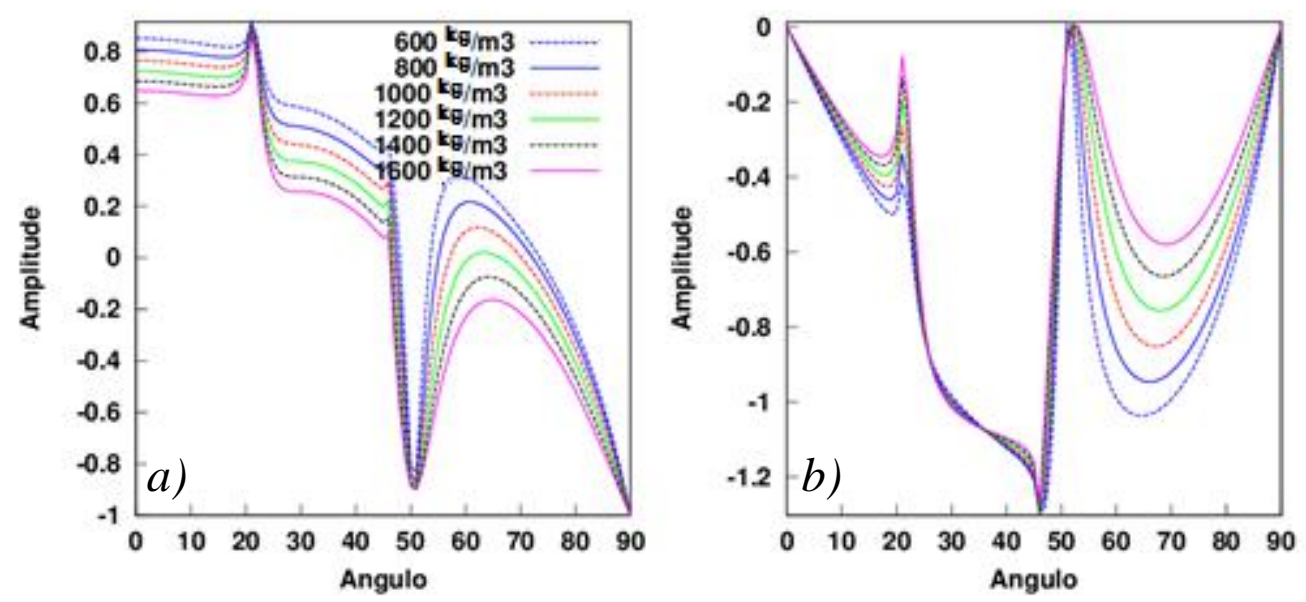

Figura 10.4: Área de Colônia: modelo de refletividade com parâmetros: $V p 1=1800 \mathrm{~m} / \mathrm{s}$, $V p 2=5000 \mathrm{~m} / \mathrm{s}, V s 1=520 \mathrm{~m} / \mathrm{s}, V s 2=2500 \mathrm{~m} / \mathrm{s}$. a) coeficiente de reflexão $R p p$ b) coeficiente de reflexão Rps. 
Para o caso da área USP, partindo da hipótese de uma camada homogênea, se construiu um modelo geológico com velocidade média de camada $\mathrm{V} 1=1550 \mathrm{~m} / \mathrm{s}$ e velocidade de embasamento V2 $=4500 \mathrm{~m} / \mathrm{s}$. A espessura estimada da camada variou de $48 \mathrm{~m}$ a $62 \mathrm{~m}$ (Figura 10.6a), mostrando uma inflexão no embasamento. Se observa uma boa concordância do modelo com a seção obtida das ondas PP e PS (Figura 10.5 e Figura 10.6 b,c).
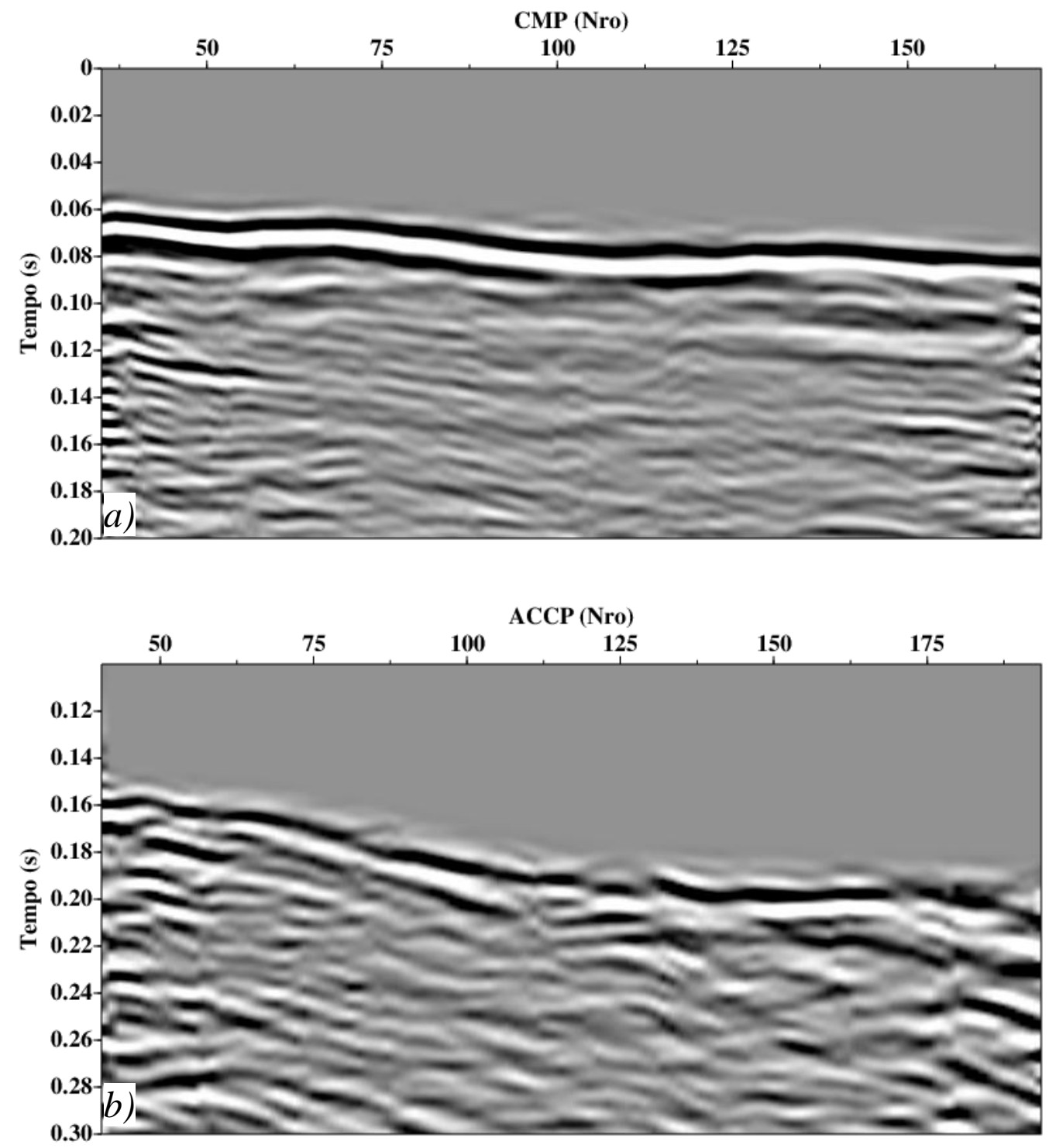

Figura 10.5: Área da USP. a) seção empilhada da componente vertical; b) seção empilhada da componente horizontal radial. 

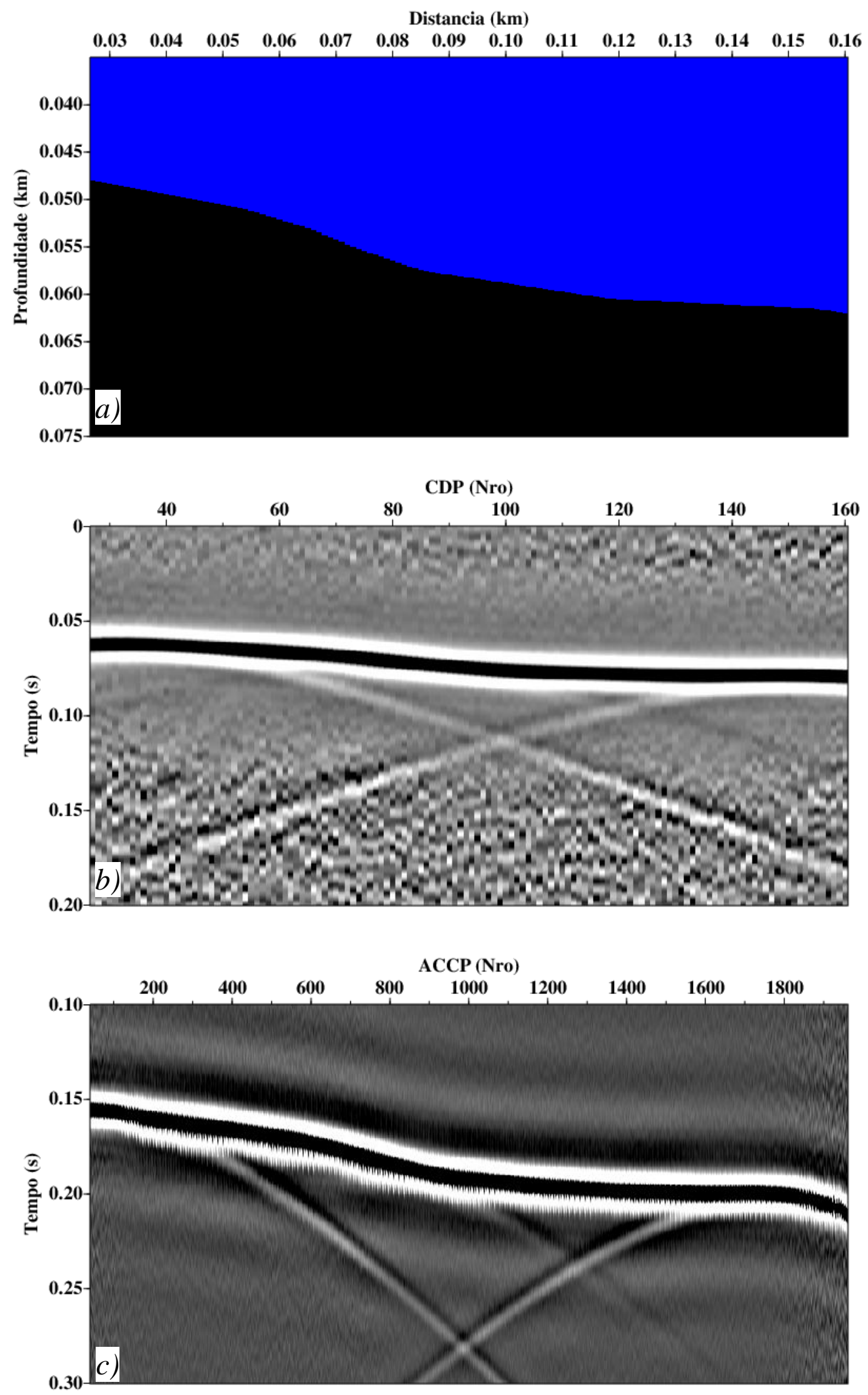

Figura 10.6: Área da USP: modelo geológico. a) modelo estrutural; b) seção modelada das ondas $P P ; c)$ seção modelada das ondas PS. 
A partir das seções PP e PS foram obtidas também a razão Vp/Vs e a razão de Poisson, usando as Equações 6.4.1 e 6.4.2. Os valores médios obtidos foram de $\mathrm{Vp} / \mathrm{Vs}=3.9$ e $\sigma=0.46$ (Figura 10.7). O valor da razão de Poisson próximo de 0.5 indica material pouco compressível.
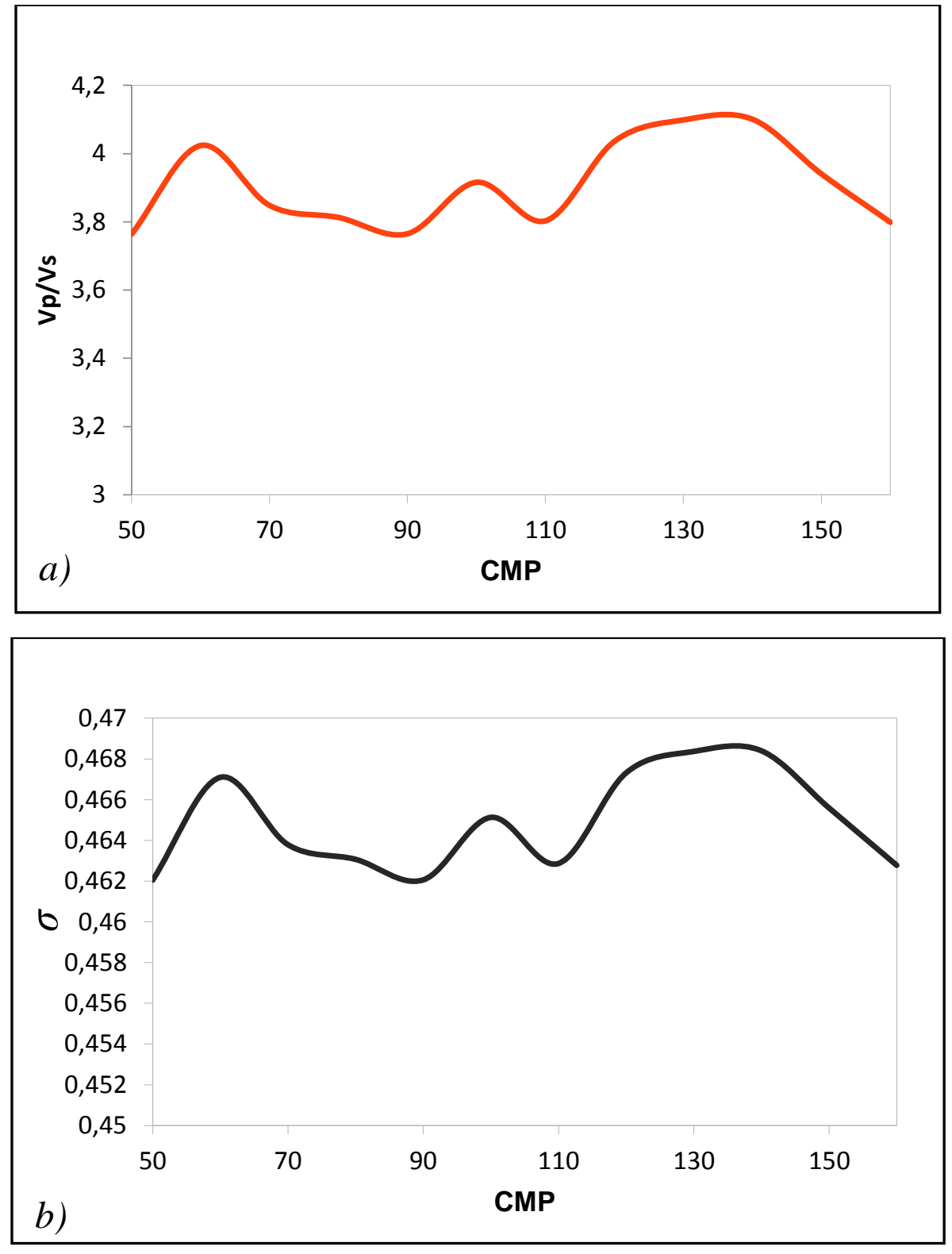

Figura 10.7: Área da USP: a) Vp/Vs calculado a partir do método de Stewart (1999); b) Coeficiente de Poisson. 


\section{Conclusões e comentários finais}

Esta pesquisa mostrou que dados de ensaio de sísmica multicomponente em área urbana podem contribuir para o estudo geológico-geotécnico da subsuperfície. No entanto, todas as etapas envolvidas no processo, desde aquisição até a interpretação final, devem ser cuidadosamente planejadas. As características da área a ser investigada também são muito importantes para o êxito do resultado final.

Mesmo que não haja informações disponíveis, tais como dados de poço da área a ser investigada, é possível estimar os parâmetros de aquisição a partir da execução do ensaio preliminar de análise de ruído. A geometria de aquisição deve ser definida visando o registro das ondas convertidas, mas pode haver alguma flexibilidade nessa etapa, e o espaçamento pode ser ajustado em função da praticidade para a execução do trabalho campo ou restrições da área, corrigindo os efeitos adversos na etapa de processamento. Por outro lado, é preciso ter em conta que diferentes geometrias de aquisição CMP com mesma multiplicidade para as ondas PP podem resultar em diferentes multiplicidades para as ondas convertidas.

Este trabalho demonstrou que é possível realizar o processamento básico usando as rotinas existentes do programa Seismic Unix, não obstante algumas etapas de processamento, tais como as de cálculo e aplicação de estáticas e DMO, não retornaram resultados satisfatórios.

Apesar da presença de três eventos de onda PP nos sismogramas de Colônia, não foi observada a onda convertida (PSv). Neste caso, consideramos que a hipótese mais plausível para explicar a ausência da onda $S$ é a atenuação em razão da existência das camadas de argila siltosa rica em matéria orgânica, constituinte principal do pacote sedimentar da estrutura de Colônia, e do nível freático subaflorante.

No Campus da USP foi obtida uma boa resposta, onde a camada de argila com matéria orgânica representa só uma pequena parte da espessura do pacote sedimentar (e nem sempre presente), e o nível freático encontra-se a uma profundidade aproximada de 8 metros. Para a área do Campus foi possível estimar os valores da razão $\mathrm{Vp} / \mathrm{Vs}$ e consequentemente os valores do coeficiente de Poisson médios para o pacote sedimentar como um todo. 


\section{REFERÊNCIAS}

Bland, H.C., Stewart, R.R., 1996, Geophone orientation, location, and polarity checking for 3-C seismic surveys. CREWES Research Report, vol. 8.

Bokhonok, O., 2011, Sísmica de Reflexão Rasa Multicomponente: Aquisição e Inversão de Tempos de Trânsito e Amplitudes. Tese de Doutorado.IAG-USP. 162p.

Chopra, S. e Stewart, R., 2010, Introduction to this special section: Multicomponent seismic. The Leading Edge, vol. 10.

Coutinho, J.M.V., 1980, Mapa geológico da Grande São Paulo, 1:100.000. São Paulo. EMPLASA. 2 folhas.

Dasios, A., McCann, C., Astin, T.R., McCann, D.M. e Fenning, P., 1999, Seismic imaging of the shallow subsurface: shear-wave case histories. Geophysical Prospecting, 47, p. 565-591.

Eaton, D.W.S., Stewart, R.R. e Harrison, M.P, 1991, The Fresnel zone for P-Sv waves. Geophysics, vol. 56. NO.3, P.360-364.

Farfour, M. e Yoon, W.J., 2016, A review on multicomponent seismology: A potential seismic application for reservoir characterization. Journal of Advanced Research, 7, 515-524.

Gaiser, J.E., 1996, Multicomponent VP/VS correlation analysis. Geophysics, vol. 61, No. 4, p.1137-1149.

Gaiser, J.E. e Jackson, A.,R., 2000, Accuracy and limitations of PS-wave conversion-point computations: How effective is reff? SEG Expanded Abstracts.

Gaiser, J., Moldoveanu, N., Macbeth, C., Michelena, R. e Spitz, S., 2001, Multicomponent technology: the players, problems, applications, and trends. Summary of the workshop sessions. The Leading Edge, 20(9), 974-977. doi: 10.1190/1.1487318.

Gaiser, J., Loinger, E., Lynn, H. e Vetri, L., 2002, Birefringence analysis at Emilio Field for fracture characterization. First Break, vol 20, No 8, pp. 505 - 514, doi: 10.1046/j.1365-2397.2002.00296.x.

Gaiser, J., 2016, 3C Seismic and VSP: Converted waves and vector wavefield applications. Distinguished Instructor Series No. 19. Society of Exploration Geophysicists. ISBN 978-1-56-080-335-5 (Volume)

Garotta, R., 2000, Shear Waves from Acquisition to Interpretation. Distinguished Instructor Series No. 3. Society of Exploration Geophysicists. ISBN 1-56080-093-3 (Volume). 
Garotta, R., Granger P.-Y. e Dariu H., 2002, Combined interpretation of PP and PS data provides direct access to elastic rock properties. The Leading Edge, 21(6), 532-535, doi: 10.1190/1.1490639.

Geldard, L.P. e Sheriff, R.E., 2004, Problems in Exploration Seismology and their Solutions. Geophysical References Series No. 14, SEG. ISBN: 978-1-56080-115-3 (Volume)

Hackspacher P.C., Dantas E.,L., Spoladore Â., 2000, Evidence of Neoproterozoic backarc basin development in the central Ribeira Belt, southeastern Brazil: new geochronological and geochemical constraints from the São Roque - Açungui groups. Revista Brasileira de Geociências 30(1):110-114.

Hall, M., Maxwell, P. e Leslie A., 2015, Seismic exploration in extreme topography: Acquisition for optimal imaging. CSEG recorder, $\mathrm{p} 28-32$.

Hao, Y., 2015, Long-Term Deformation in the Mississippi Embayment (Central USA) Imaged by High-Resolution Seismic Reflection Data. PhD Dissertation, Department of Earth Sciences, Southern Methodist University, Dallas, Texas.

Hardage, B.A., DeAngelo, M.V., Murray, P.E., Sava, D.,2011, Multicomponent Seismic. Technology Geophysical References, Series No. 18, SEG, ISBN 978-0-931830-47-1.

Hardage, B.A., 2017, Land based S-wave reflection seismology with P sources - does it work? SEG International Exposition and 87th Annual Meeting.

Harlan, W.S., Claerbout, J.F. and Rocca, F., 1984, Signal/noise separation and velocity estimation. Geophysics, vol. 49, No 11, 1869-1880.

Hasui, Y., Carneiro, C.D.R., Coimbra, A.M., 1975, The Ribeira Folded Belt. Revista Brasileira de Geociências, vol. 5, pp. 257-266.

Hoffe, B. H., Margrave, G. F., Stewart, R. R, Foltinek, D. S., Blan, H. S. e Manning, P. M., 2002, Analyzing the effectiveness of receiver arrays for multicomponent seismic exploration. Geophysics, vol. 67, no. 6, p. 1853-1868

Hüseyin, O., Flanagan, K. e Tyler, E., 2010, Litology and hydrocarbon mapping from multicomponent seismic data. Geophysical prospecting, 58, 297-306.

Kearey, P., Brooks, M, Hill, I.,2002, An Introduction to Geophysical Exploration. 3rd ed. 262 pp Malden, MA : Blackwell Science.

Kollert, R., Björnberg, A. e Davino, A., 1961, Estudos preliminares de uma depressão circular na região de Colônia: Santo Amaro, São Paulo. Boletim da Sociedade Brasileira de Geologia, vol. 3(10), pp. 57-77.

Maercklin, N., 2001, SUPOLAR and SUPOFILT: SU programs for polarization analysis and filtering of three-component data. DOI: 10.13140/2.1.1697.7926.

Meier, M.A., 2009, Converted-wave survey design. SEG Houston International Exposition and Annual Meeting. 
Meunier, J., 2011, Seismic acquisition from yesterday to tomorrow. 2011 Distinguished Instructor Short Course. SEG \& EAGE Distinguished Instructor Series, No. 14. ISBN 978-1-56080-281-5 (Volume)

Miller, R.D., Pullan, S.E., Haeni, Waldner, J.S., 1986, Field comparison of shallow seismic sources. Geophysics, vol. 51, p. 2067-2092. 30.

Motta, U.S., e Flexor, J.-M., 1991, Estudo gravimétrico da depressão circular de colônia, São Paulo, Brasil. II Congresso Internacional da Sociedade Brasileira de Geofísica, Anais, Salvador, Bahia, pp.140-142.

Porsani, J.L., Rodrigues Borges, W., Vagner, R.E., Diogo, L.A., Hiodo, F.Y., Marrano, A. e Birelli, C.A., 2004, Investigações geofísicas de superfície e de poço no sitio controlado de geofísica rasa do IAG-USP. Revista Brasileira de Geofísica. 22(3): 245258.

Pugin, A., Pullan, S. e Hunter, J., 2013, Sher-wave high-resolution seismic reflection in Ottawa and Quebec City, Canada. TLE, pp 250-255.

Riccomini, C., Turcq, B.J., Martin, L., Moreira, M.Z.; Lorscheitter, M.L., 1991. The Colônia Astrobleme, Brazil. Revista do Instituto Geológico, vol. 12, pp.87-94.

Riccomini, C., Gomes Sant'Anna, L. e Ferrari, A.L., 2004, Evolução geológica do Rift Continental do Sudeste do Brasil. Geologia do continente Sul-Americano: evolução da obra de Fernando Flávio de Almeida. pp.383-406.

Riccomini, C., Crosta, A.P., Prado, R.L. e Lendru, M.-P., 2011, The Colonia structure, São Paulo, Brazil. Meteoritics \& Planetary Science 46, $\mathrm{Nr}$ 11, 1630-1639, doi: 10.1111/j.1945-5100.2011.01252.x.

Sadowski, G.R., 1974, Tectônica da Serra de Cubatão, SP. Tese de Doutorado pelo Instituto de Geociências da Universidade de São Paulo, São Paulo. 159p.

Sadowski, G.R. e Campanha, G.A.C, 2004, Grandes Falhas no Brasil Continental. Geologia do Continente Sul-Americano: Evolução da Obra de Fernando Flávio Marques de Almeida. São Paulo. pp. 407-421.

Santos, A.H.B, 2013, Condicionantes estruturais da drenagem e do relevo na cratera de Colônia e entorno, São Paulo-SP. Dissertação de Mestrado, Fac. De Filosofia, Letras e Ciências Humanas, USP.

Schafer, A.A.W., 1992, A comparison of converted-wave binning methods using a synthetic model of the Highwood Structure. CREWES Research Report, vol. 4.

Stewart, R.R., Gaiser, J.E., Brown, J.R. e Lawton, D.C., 1999, Converted-wave seismic exploration: a tutorial. CREWES Research Report, Vol. 11.

Stewart, R.R., Gaiser, J. E., Brown, J.R. e Lawton, D.C., 2002, Converted-wave seismic exploration: Methods. Geophysics, vol. 67, no. 5; p. 1348-1363. 
Stewart, R.R., Gaiser, J.E., Brown, J.R. e Lawton, D.C., 2003, Converted-wave seismic exploration: Applications. Geophysics, vol. 68 no. 1; p. 40-57.

Stewart, R.R., 2008, Methods of multicomponent seismic data interpretation. 70th EAGE Conference \& Exhibition- Rome, Italy.

Stockwell, J.W. e Cohen, J.K. (2002). The new SU user's manual. Center for Wave phenomena, Colorado School of Mines, Golden, Colorado, USA, 3.2 edition.

Tatham, R.H., 1991, Multicomponent seismology in petroleum exploration. Investigations in geophysics series, vol. 6. ISBN 1-56080-051-8 (Volume)

Velázquez, V.F., Riccomini, C., Azevedo Sobrinho, J.M., Pletsch, M.A.J.S., Sallun, A.E.M., Sallun Filho, W. e Hachiro, J., 2013, Evidence of shock metamorphism effects in allochthonous breccia deposits from the Colônia Crater, São Paulo, Brazil. International Journal of Geosciences, vol. 4(1A), pp. 274-282. 


\section{ANEXO - ACCP binning}

A geometria de aquisição deve ser definida visando ao registro das ondas convertidas, mas pode haver alguma flexibilidade nessa etapa e o espaçamento pode ser ajustado em função da praticidade para a execução do trabalho campo ou restrições da área, corrigindo os efeitos adversos na etapa de processamento.

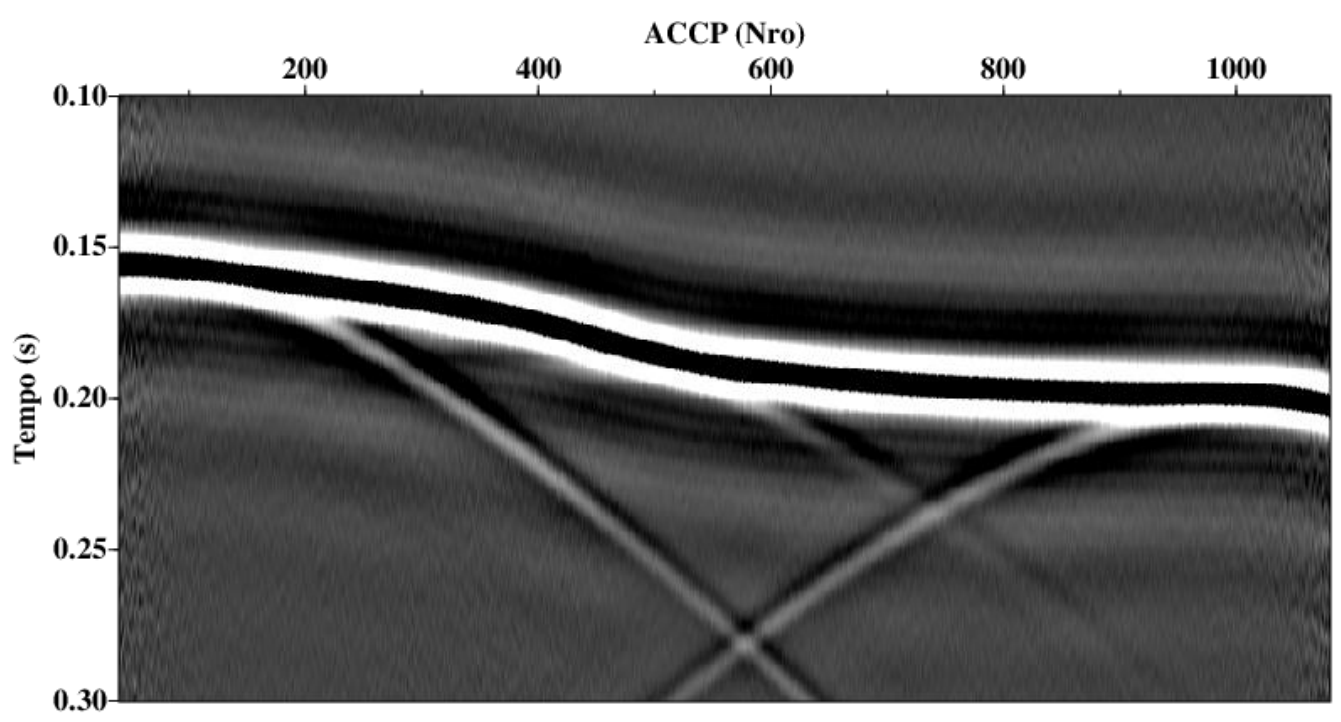

Figura 1: Modelo das ondas convertidas (espaçamento entre geofones e entre fontes de $1 \mathrm{~m}$ ). Parâmetros de ACCP binning: $V p / V s=4$

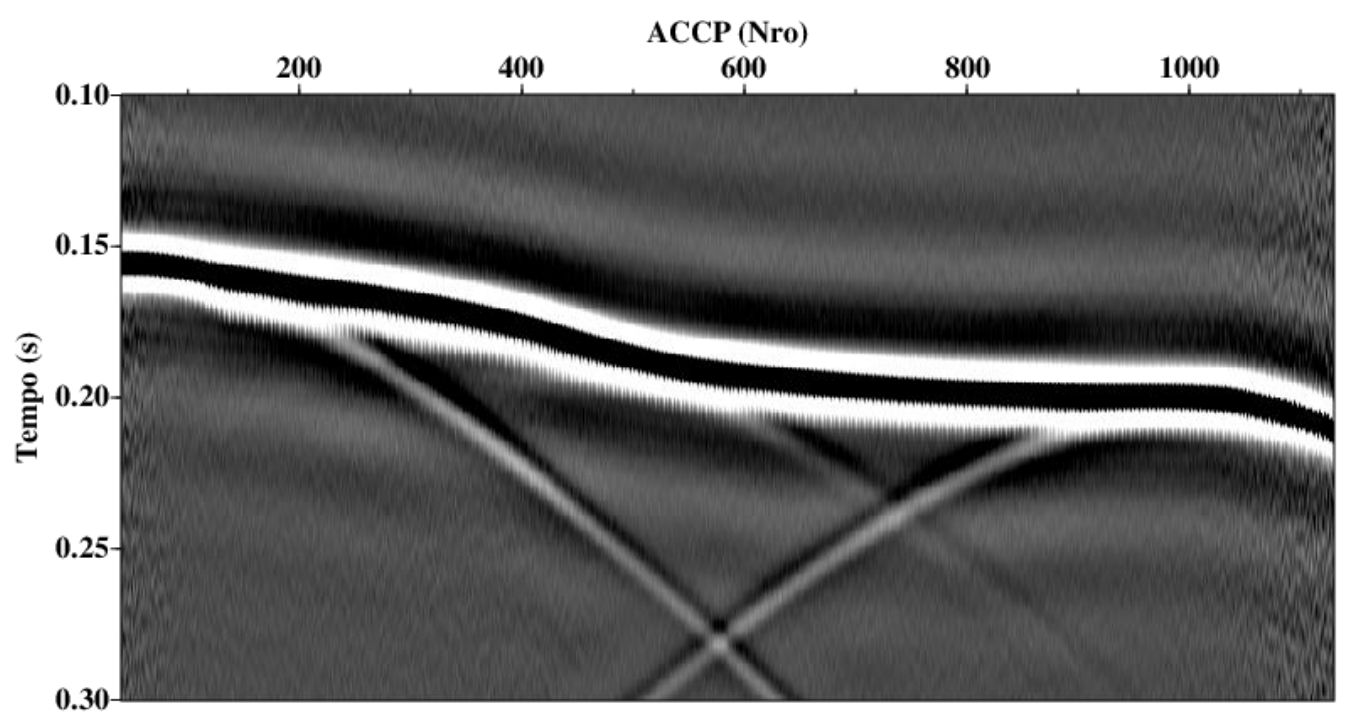

Figura 2: Modelo das ondas convertidas (espaçamento entre geofones e entre fontes de $2 \mathrm{~m}$ ). Parâmetros de ACCP binning: Vp/Vs=4

As figuras a seguir apresentam o modelo das ondas convertidas considerando a razão $\mathrm{Vp} / \mathrm{Vs}=4$ com espaçamento entre os geofones e fontes de $1 \mathrm{~m}$ (Figura 1) e com espaçamento de $2 \mathrm{~m}$ (Figura 2). O ordenamento dos traços nos conjuntos ACCP foi realizado mediante a 
Formula 6.3.4.1. Como se observa, ocorre uma leve distorção na imagem com o aumento do espaçamento (Figura 2). A imagem pode ser melhorada, aplicando filtro mute nos últimos traços do conjunto ACCP (Figura 3).

A multiplicidade dos traços varia dependendo da razão Vp/Vs usada. Por exemplo, para o caso de espaçamento de 2 metros, no caso de $\mathrm{Vp} / \mathrm{Vs}=2, \mathrm{Vp} / \mathrm{Vs}=2.5, \mathrm{Vp} / \mathrm{Vs}=3.5, \mathrm{Vp} / \mathrm{Vs}=4.5$ e $\mathrm{Vp} / \mathrm{Vs}=5$, agrupando os traços ao multiplicar os valores calculados dos conjuntos CP por 100, chega-se a um valor máximo de multiplicidade igual a 3. Por outro lado, para $\mathrm{Vp} / \mathrm{Vs}=3$ ou $\mathrm{Vp} / \mathrm{Vs}=4$, agrupando os traços ao se multiplicar os valores de CP por 10, a multiplicidade máxima chega até 14 traços. Como a multiplicidade é um dos fatores de qualidade que influi consideravelmente na qualidade da imagem, se escolhe usar $\mathrm{Vp} / \mathrm{Vs}=3$ ou 4 para realizar o ordenamento de traços nos conjuntos ACCP mediante a Formula 6.3.4.1 para a geometria com espaçamentos de 2 metros entre os receptores e os geofones.

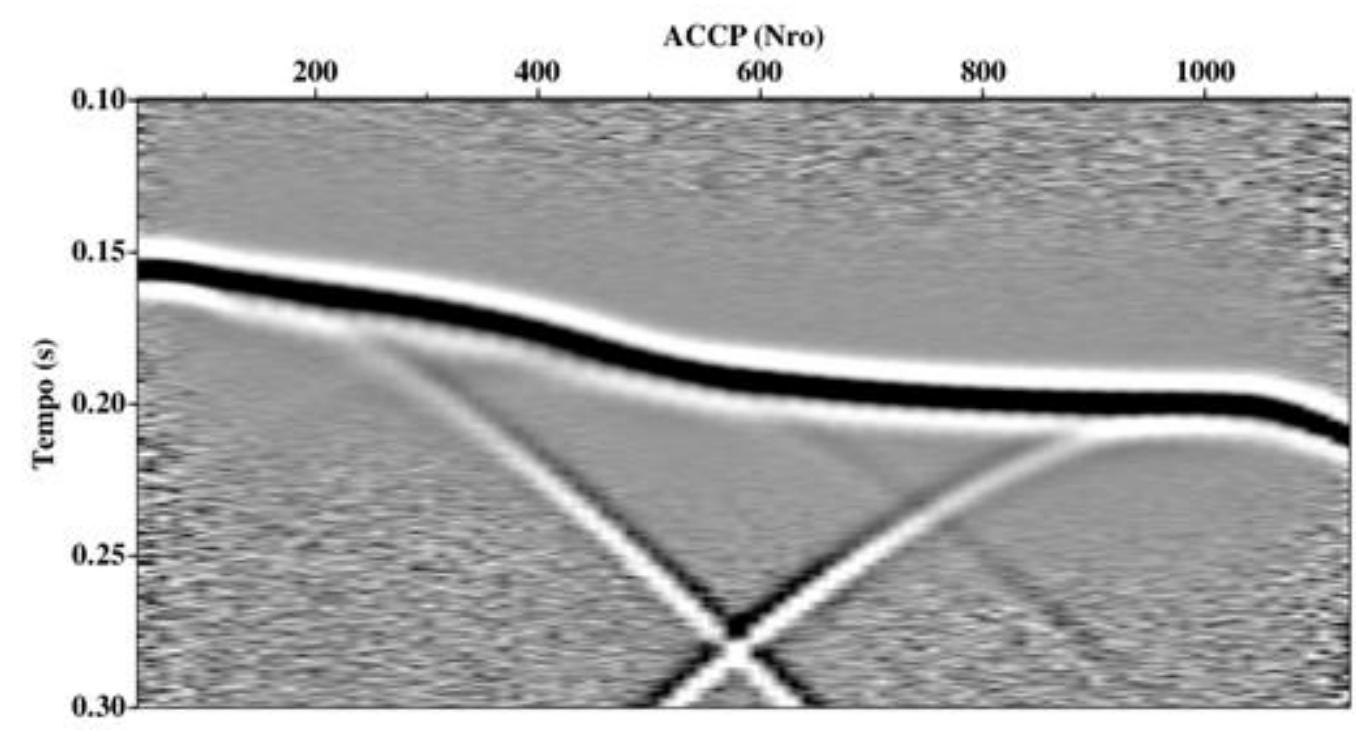

Figura 3: Modelo das ondas convertidas com mute aplicado nos últimos traços de conjunto ACCP (espaçamento entre geofones e entre fontes de $2 \mathrm{~m}$ ). Parâmetros de ACCP binning: $\mathrm{Vp} / \mathrm{Vs}=4$ 